Magnetic Fusion Energy

Plasma Interactive and High Heat Flux Components

\author{
Volume II
}

Technical Assessment of the

Critical Issues and Problem Areas in

High Heat Flux Materials \& Component

Development

June 1984

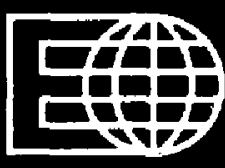




\title{
DISCLAIMER
}

This report was prepared as an account of work sponsored by the Undted States Government. Neither the Undted States nor the Inited States Department of Energy, nor any of their employees, makes any warranty, express or 1mplied, or assumes any legal llability or responsibtlity for the accuracy, completeness, or usefulness of any information, apparatus, produrt, or process disclosed, or represents. that its use would not infringe privately owned rights. Reference herein to any specific commercial product, process, or service by trade name, mark, manufacturer, or otherwise, does not necessarily constitute or imply its endorsement, recommendation, or favoring by the United States Government or any agency thereof. The views and opinions of authors expressed herein do not necessarfly state or reflect those of the Unfted States Government or any agency thereof.

Printed in the United States of America

\author{
Avallable from: \\ National Technfcal Information Servime \\ U.S. Department of Commerce \\ 5285 Port Royal Road \\ Springfield, Virginia 22161 \\ Price: Printed Copy A02 \\ Microfiche ADI
}


UCLA/PPG--815

DE85 001155

\author{
Volume II \\ Technical Assessment of the \\ Critical Issues and Problem Areas in \\ High Heat Flux Materials \& Component Development
}

\title{
Lead Auchors
}

M. A. Abdou (UCLA), Assessment Cha1rman

R. D. Boyd (SNLA)

J. R. Easoz (Westinghouse)

W. B. Gauster (SNLA)

J. D. Gordon (TRH)

R. F. Mattas (ANL)

G. D. Morgan (MDAC)

M. A. Ulrickson (PPPL)

R. D. Watson (SNLA)

W. G. Wolfer (UW)

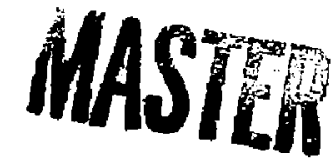




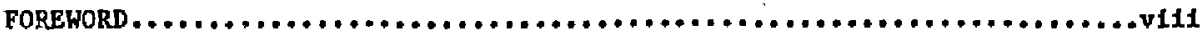

SUMMARY

.$+\pi 1$

I. SOURCE CONDITIONS

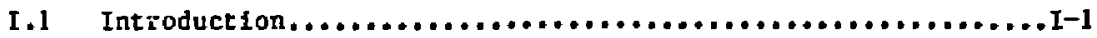

I.2 The Data Base on Present Devices.......................I-2

L.3 Theoretical Understanding of Operating conditions.......... I-6

I.4 Predictions of Operating Conditions for Future Machines...... I-7

I.5 Assessment of Operating Conditions and Future Neec's......... I-9

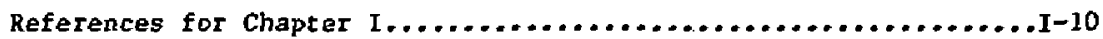

II. SYSTEMS INTEGRATION

II.I Introduction ..................................... II-1

II.2 HHF Components Location and Description.................II-I

II.3 Systems Integration Constderations..................... I-20

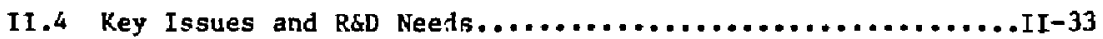

References for Chapter II ............................... II 36

III. MATERIALS AND PROCESSES

III.1 Operating Condttions.................................

III.2 Plasma Side Materlals............................... III-5

III.3 Heat SInk Materlals.............................. III-10

III.4 Interface/Attachment ................................ III-19

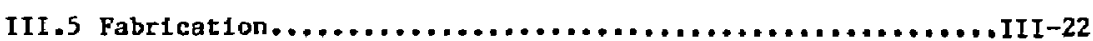

III.6 other Issues-Tritium Permeation.................... II-31

III.7 Materials and Processes Technology Needa.............. III-32

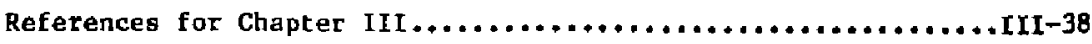


IV. THERMAL HYDRAULICS

IV.1 Introduction. .................................... IV-1

IV.2 Three High fieat FIux Heat Rewoval Techniques.................IV-1

IV.3 Conparison of Three High Heat Flux Heat Removal

Technfques...................................... IV 10

IV.4 Conclugions and Recommendations.......................IV-11

References for Chapter IV...............................IV-15

V. THERMOMECHANICAL RESPONSE

V.1 Thermal Response..................................

v.2 Structural Response.................................v-9

v.3 Fallure Analysis................................. v-15

v.4 Design Criter1a................................v-20

v.5 Thermcmechanical Testing.............................

V.6 R\&D Needs....................................

v.t Critlcal Issues....................................

References for Ghapter $v \ldots \ldots \ldots \ldots \ldots \ldots \ldots \ldots \ldots \ldots \ldots \ldots \ldots \ldots \ldots \ldots . . \ldots$. 29

VI. ELEGTROMAGNETIC RESPONSE

VI.I Introduction to the Issues........................

vi.2 Eddy Current Codes..............................vI-5

VI.3 Coupling of Eddy Currents to Thermomechanfcal Response......VI-6

VI.4 Conclusions and Recommendations......................VI-10

References for Chapter vi..........................vI-13

viI. HIGH HEAT fLUX COMPONENT TEST FACILITIES $\ldots \ldots \ldots \ldots \ldots \ldots \ldots \ldots \ldots \ldots$. $\ldots \ldots$

VIII. INSTRUNENTATION AND CONTROL

VIII.1 Introduction...............................vIII-1

VIIr.2 Measurement Requirements........................... VIII-2

VIII.3 Control Requirements...........................VIII-6

VIII.4 Operat1ng Environment and Device Interfacing............VIII-11

VIIL.5 Ingtrumentation and Control Techniques...............vIII-14

VIII.6 Conclusions and Recommendations...................

References for Chapter VIII.........................viII-22 


\section{List of Flgures}

P1g.

T1tle

Page

I-1 Time scale on which current decays in var1ous devices............ I-5

II-1 Tokamak first wall location.............................II-3

II-2 Example of configuration for water-covled f1rot wall............II-3

II-3 Examples of armor for tokamak first wall....................II-4

II 4 Positioning and startup limiters..........................II-5

II-5 Typical single-nul1 polotdal divertor configuration.............II-7

II-6 Inner divertor collector plate configuracion.................II-7

II-7 Limiter configuration (1982 U.S. INTOR reference design).........II-8

II-8 Neutral Beam Engineering Test Fac1lity (NBETF) Ion dump.........II-9

II-9 Actlvely cooled heat absorption panel for NBETF..............II-9

II-10 TFTR accelerator source grid assembly ......................II-11

II-11 EBT-S ICRH antenna...............................II-11

II-12 MFTF-U: Beam and reactor layout ........................II-13

II-13 External beam dump configuration.........................II-13

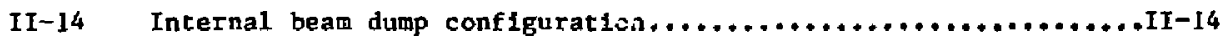

II-15 Typical beaw durp design.............................

II-16 End cell configuration...............................

II-17 Inner halo configuration and analysis....................

II 18 Impact of avallability in experimental fusion devices..........II-31

II-19 Comparison of Ifalter maintainance approaches for STARF IRE

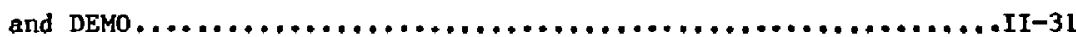

IV-1 Predictions of the exit conditions... as a function of

mass velocity.......................................

IV-2 Predictions of the exit conditions... as a function of mass flow rate.......................................

IV-3 Predictions of the pumping and the exit wall temperature as a function of velocity............................... TV-9 
V-1 Combinations of surface heat flux and pulse length required to melt the surface of an uncooled, therma11y thick" nater1al.....

V-2 Heat capacity figure-of-merit. Larger numbers Imply that wore heat can be absorbed In a given amount of time without welting...............................................

V-3 Haximum heat flux needed to melt the burface of a 1 cm thick pipte cooled on 1 ts backside to $100^{\circ} \mathrm{C}$ during ateady-atate condtttons............................................. v-5

$\mathrm{V}-4 \quad$ Amount of material melted during a 20 ms plasma disruption.......V-7

V-5 Amount of material vaporized auring a $20 \mathrm{mg}$ plasma distupt1on.... y-8

V-6 Thermal stress Eigure-of-mertt for transient heating ..........V-11

V-7 Thermal stress flgure-of-merit for steady-state heating ........-I2

V-8 Triplex 3-1ayer construction of a high heat flux component......V-14

VI-1 Interrelation of the three responses (heating, electromagnet Ic loading, and transient stresses) of an in-vegsel component to plasma discuptione........................vI-8 


\section{L1at of Tables}

Table

Ticle

$\underline{\text { Page }}$

I-1 Operating cond1tions of exist1ng devices......................

I-2 Predfcted operating conditions in future devices................. I-8

II-I Inner collector fluxes...............................II-17

II-2 Halo scraper fluxes................................... II-17

II-3 Compartson of activation for vartous HHFC matertals............II-25

II-4 Estimated requirements for rellability of HHF components

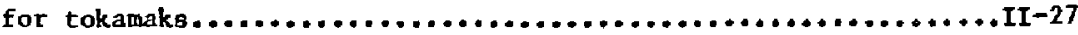

II-5 Effect of 11miter location and coolant chofce on tritfum breeding ratfo.........................................II-32

III-1 Impurity control parameters - tokamaks......................

III-2 Property values at $800 \mathrm{~K}$ for low-Z materlals.................IIi-8

III-3 Properties of high-2 materials at $500 \mathrm{~K} \ldots \ldots \ldots \ldots \ldots \ldots \ldots \ldots \ldots . \ldots . \ldots . \ldots$

III-4 Candidate heat sink copper alloys........................II -12

III-5 Candidate refractory metal alloys........................III-15

IV-1 Comparison of three high flux heat removal alternatives........IV-12

v-1 Time-1ndependent fallure modes..........................

v-2 Time-dependent fallure modes.........................

$v-3 \quad$ Damage mechantstw $\ldots \ldots \ldots \ldots \ldots \ldots \ldots \ldots \ldots \ldots \ldots \ldots \ldots \ldots \ldots \ldots \ldots . \ldots \ldots$

$v-4 \quad$ Critical. Issues for fallure analysis.......................

v-5 Sumary of testing of actively cooled componerts...........v-22-24

I-1 Magnetic diffugivity, $K$, and okin deptiss, $\delta$, for a few metallic matertals.....................................vi-4

VI-2 Rectangular geometry eddy current computer programs.............VI-7

vII-1 Dedicated electron test facilities........................ VII-2

VII-2 Dedicated ton test facilities...........................VII-3

VII-3 Neutral beam and RF tegt stand characteristics..............VII-4 
VIII-I Measurement requirements and potential techniques for HHF components $. v 1 I I-3$

VIII-2 Potentlal control loops involving HHF components............vIII-8 VIII-3 HHF component environment related concerns for I\&C systems $\ldots \ldots \ldots \ldots \ldots \ldots \ldots \ldots \ldots \ldots \ldots \ldots \ldots \ldots \ldots \ldots \ldots \ldots$.............. 
The eaphasis of the present planning process is to examine potential probleas, state of technical readinese, and to priozitize materialo-related requfrements which must be satlafled for the ouccessful development of fuston reactors.

It 18 important to realize that the assessments and plans describe problem areas, and the approach to solutions as seen today are significantly different from those which were outlined In 1978, and that these will have to be updated perfodically. Furthermore, they should be regarded as outlining the major avenues to be explored, rather than as a detalled road map. Although a task structure w1ll be outlined fn the Program Plans, the detafled approach to the solution of spectfic problemg will be proposed by Individual Investigators.

Including memberships on sub-task groups, atal of over 50 Individuals will be Involved in various stages of the operation of the PMI and HHFMCD Technical Assessments and Program Plans. The wide representation of national laboratories, universities, and 1ndustry was encouraged to remove institutional blas to the greatest extent possible.

In conclusion, I would like to take thls opportunity to thank all of the members of the Task Group and the technical community who contributed to this effort and who continue to be the most 1mportant element in the success of the reactor technology area.

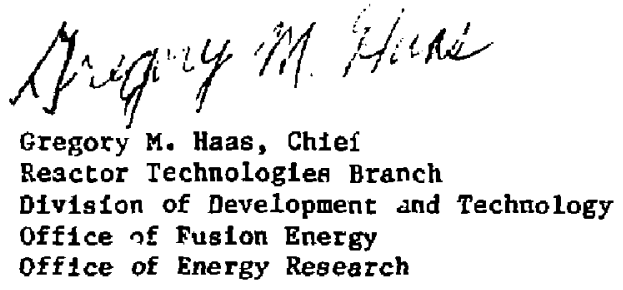




\begin{abstract}
FOREWORD
Technical Assersent of the Criticai Issures and Problem Areas In High Heat Flux Materiala and Cosponert Developaent
\end{abstract}

At the present tine, the magnetc fusion energy effoct in materials developnent is incorporated within the Reactor Technologitg Bransh of the Division of Development and Technology in the Office of Vuston Energy (OFE). Alse Included within the Reactor Technologles task area 1s work on Pla:isa Materlals Interaction (PMI), which 18 clogely linked to the High Heat Flux Metertals and Component Derelopment (HAFMCD).

As a reflection of increased prograinnatic erghaeis on alternate concepti, a HHFMCD Tagk Group has beeu Initiated and includes mezbers of lo mirror and compact torold communities. The chairman of this Task Group 1s Dr. Mark Dav1s, Sandia National Latoratories (SNL), Albuquerque, New Mertco. Ira add1tion, the takk group on PHI has becn expandrd under the el ilrmanghip of Dr. Halter Bauer, Sandla National Laboratorles (SNA), LIvermore, California. Dr. W11held Gauster (St) functions na conrifnator between the activities of the two groups.

Two new Techntcal Assessments and Progrom plans have been Inftiated in the PMI and the IHFHCL areas. Th1s HHFHCD Trehrical Asegesuent 18 pert of the first update of the Fusion Reactor Materiaje Program Plan which was compleced in 1978 and whtch consisted of four elements:

AJloy Development for Irradiation Performance (ADLP)

Damage Anriysis and Fundamental studieg (DAFS)

Plasma Materials Interaction (PHI)

Special Purpose Materials (SPM)

In t'ie intervoning six years, algnificant progregg has been rade ta each of these areas. In particular, the HHFHCD area has begun in response to

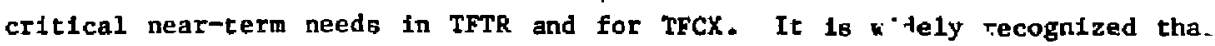
It Is of vital importance for these programs to be able to focug part of each of the Individual elements of this task area on the design, fabricacton, and maintenance of near-term HHFMCD gywams which ptovide the Integrating function for all the separete elements of the program. 
Much of the succest of the EHFHCD and PMI prograns 1s a direct reault of this focusing. At present, tasks are being carried out in (and linked to the success of) present and planned agnetic funton physics factlities, both within the U.S. and abrosd. Interantional collaboration and joint design on esch components as purp listcers, divertors, halo ecrapers, diagnostics, and wall conditioning heve been performed both in conjunction with the U.S. plasma phystes comunity and that of ather nations. Such Reactor Technologies PMI and HHFMCD rasks are being carried out in and for such devices as TFTR, TEXTOR, JET, and MFTF-B.

These Technical Assessments and Program Plans are belng prepared by takk groups composed of persons from the varlous laboratorles and contractorg that contribute to the Magnetic Eusion Energy program. Each task group of six to ten prinetpal 1nvestigators and/or consultants work under the guidance of a chatrman drawn from a national laboratory and his counterpart, a staff member of the Reactor Technologies Branch. In the case of PMI and HHFMCD, the counterpart is $\mathrm{Dr}$. Marvin $M_{n}$ Cohen. The efforts leading to the Technical Assessment in the PMI area were chalred by Professor Robert Conn of the Unfversity of Callfornia, Los Angeles (UCLA). The Program Plan, which will represent the OFE strategy for the implementation of a progran designed to address the requirements set out in the present Technical Agsessment, will be chalred by Dr. Bater. In the area of HHFMCD, the Technical Assessment was chalred by Professor Mohamed Abdou, UCLA, and the Program Plan will be chalred 'y Dr. W. Gauster and co-chalred by Professor Abdau.

Each chalrian operates through a number of ad-hoc sub-task groups which were charged with problew definition and program planning for specific techniczi areas.

The assumptions lnherent in the planning process are (1) the demonstration of scientific feasibility in the TRTR by 1987, and (2) the operation of $a$ modest ling-pulse Ignition wachine before the end of the century. Beyond these assumptions, the Technical Assessments and Program Plans deal with genertc materials and diagnostic and systems integration needs, irrespective of the magnetic confinement system. To the extant that such generic problens apply to hybrid reactors and Iaser fualon reactors, the plans are applicable to them as well. However, they do not Include tasks opectfite to hybrids (e.g., fuels) or laser fustion (e.g., optlcal matertals and ultra high frequency pulsing or ramp tates.) 
SUMMARY

A techntcal assessment of the critical losues and problem areas for high heat flux materials and components (HHFMC) In magnetic fusion devices shows these problems to be of critical fmportance for the successful operation of near-term fusion expertments and for the feastbility and attractiveness of long-term fuston reactors .

Both the challenge and the need for success in resolving the problems of HHFMC become greater as progress is made toward sustaining longer plasma burns and achleving higher power density. Thege problems relate to many fields or sctence and engineering: plasma physics, surface sclences, matertals, thermal hydraulics, structural mechanics, electromagnetics and neutronics. Many of these problems require extensive long-term development and should recelve attention now.

A number of subgroups were formed to assess the critfcal HHFis lobues along the following mejor lines: 1) source conditions, 2) systems integration, 3) matertals and processes, 4; thermal hydraulics, 5) thermonechanical response, 5) electromagnetic response, 7) instrumentation and control, and 8) test factlities. The detalls of the technical assessment are presented in the following eight chapters. The primary technical lisues and needs for each area are highlighted below.

\section{A. Source Conditions}

\section{A.1 Charactertsation of Plasma Edge Condicions}

Knowledge of the plasma edge conditions is eructal to the design of high heat flux components (HHFC). Therefore, attention must be pald to obtaining desa on the plasma edge conditions from piesent and future devices. In addition, continuing theoretical studies are requi.red to uncover and understand the Important physical processes.

\section{A.2 Control of Plasma Edge Conditions}

There are great incentives to attempt mechanisms for controlling the plasma edge conditions in order to provide a less harah environment for opera- 
tica of the HAFC. One particularly laportant goal is to achleve sufficlently low plasma temperature at the neutrallzer plate in toroldal confinement devices so as to use high-z materialo with low erosion and higk diaruptionresisicance. The degree of Buccess may vary substantially with the lmpurity control scheme, e.g., pump limiters or divertors.

\section{B. System Integration}

Many of the issues identifled in the varlous technical areas translate Into operational, economic and safety syatem 18sues.

\section{B.1 Lifetime of HHFC}

Present estimates predict short lifetime for many of the HHFC, particularly the limiter and divertor plates in toroldal devices and the halo scrapers In tandem mirrors under certain operating conditione. Thus, the following $\bar{a}=23$ need to be emphasized: a) exploring plagma edge conditions that minituIze eroston, b) development of means to elfminate or minimize plasma disruptIons and other off-normal conditions, c) experimental and theoretical efforts to provide rellable estimaces of erosion and redeposition of plasma-side materials, and d) development of designs of HHrC and fusion devices that permit rapid replacement of components that have short 11 fe.

\section{B.2 Tritium Contamination of Coolants in HHFC}

There are large uncertainties in predicting tritium permeation rates into the coolants of HHFC. High tritlum concentrations in coolants is a safety 1ssue and tritium removal from water is costly. Therefore, experimental data on tritium permeation unde: realistic conditions is needed. In addition, the development of effective tritium barriers should be explored.

\section{B.3 Interaction of Coolants in HHFC with Other Subsysteme}

The simultaneous use or water fo HHPC, e.g., limiter or divertor, and 11quid metals in other components such as the blanket 1s presentig perceived to entall significant safety risk. Therefore, experimental and analytical efforts are required to: a) Identify viable coolants for HHFC other than water, b) determine the probabilities and consequences of accidents that involve water in HHFC and 1iquid metals in other componente. 


\section{B.4 Effect of HifC on Achleving Fuel Self-Suffictency in DT Fueton Deviceg}

HAFC, part1cuierly the impurity control and exhaust systems (divertors and indters), w11 have a substantial lapact on the ability of fuston devices operated on the DT cycle to achleve fuel self oufficlency. This 1mpact falls Into two areas: a) reducting the achlevable tritium breeding ratio by occupylng relatively large volume of the breeding blanket and parasitic absorption of neutrons and b) Increasing the required breeding ratio if the tritfum recycling into the plasma is reduced.

I'here are substantial differences between the limiter and divertors and the varfous design concepts for both eypes of 1mpurity c ntrol and exhaust systems. Therefore, substantial effort In the phystr and engineering is required to develop impurity control and exhaust conceyts that minimize the phystcal space requirements and maximize the tritium fractional burn-up in the plasma.

\section{c. Materlals and Processes}

The critical issues for high heat flux matertals and processes can be conventently divided lato near-term and 1 ong-term lssues.

\section{C.1 Near Term Issues}

\section{C.1 .1 Plasma-S1de Mater1als}

There are several surfice-related critical lssues for plasma-side materials. In the case of graphite, the key 1ssue 18 the impact of chemlcal sputtering on plasma operation. For beryllium, the critical issue to the response of the material to disruptions, particularly melt layer formation and erosion. For the conpounds, such as SIC and BeO, the critical issue is the possible change in surface composition and properties with preferential sputtering. In the case of high-z materials, the point where the gelf-sputtering coeffictent exceeds unity $1_{8}$ the most important 18sue. A crittcal losue assoclated with all plasmi-side materials ts the lack of a comprehensive bulk property catabase. 


\section{C.1.2 Beat-S1nk Yaterials}

The major lasue assoclated with heat-alnk materials is the lack of a comprehenglve bulk property data bage, Copper alloys are the leading candidates for heat-aink materials in the near term. More infornation is needed in the areas of elevated temperature tengile properties and fatigue/crack growth behavior before a reference alloy can be selected.

\section{C.1.3 Duplex Structures and Attachment}

A major need for HHFC is the development of fabrication and bonding techniques for structures composed of both plasma-side and heat-sfnk materials. Specific bonding xethods have not get been developed and the propertles of the bonds are largely unknown. A Becondary 1ssue is the possible impact of bonding fabrication on the bulk properties of the heat sink. The temperature required for bonding may be in the range where the mechantcal properties of ecpper alloys are serlously degraded.

\section{C.2 Long Term Issues}

For long-term applieation, HHFC w111 be subjected to moderate to high neutron fluences. The critical isgue with a radiation environment is whether the HHFC are sufficiently resistant to radiation damage to operate for the desired 11fetime. The materials used for HHFC are congtdered to be new to the study of radiation damage effects, so there to very little data ava1lable. An extensive program will ultimately be required to examine the effects of radiation on the thermophysical propertieg, mechanical properties, and the dimenstonal stability of materials in a radiation etivironment.

The use of refractory metals in HHFC appears destrable for some operating conditions. The major 1ssue assoctated with these metals is the lack of an adequate baseline and fabrication data base. The needs include the acquisition of daca on all relevant bulk properties $\mathrm{in}$ both the unirradiated and Irradiated conditions. In addition, the corrosion behavior of water and 11quid metals needs to be understood. There is a possibility that refractory metals will be used in near-terw devices, such as MFTF-a+T. If this is the case, the development of refractory metals w111 become a near-term 18gue. 


\section{C.3 R\&D Prograno}

The critical losues can be addresesd with five agjor R\&D proficaus, as follows.

\section{C.3.1 Development and Selection of Plagng S1de Materlals}

The aurface and bulk properties of candidate plasma-side materia1s should be examined for temperatures ranging from roon temperature to $\sim 1000^{\circ} \mathrm{C}$. Since fabrication processes can significantis Influence the properties, the mat ertals ghould be tested in several fabricated forms. The goal of this program is the selection of the best plasma-8ide material for near-term applications.

\section{C.3.2 Developrent and Selection of Copper Heat S1nk Alloys}

The bulk properties of candidate copper alloys w11 be determined for temperalures ranging from room temperature to $\sim 400^{\circ} \mathrm{C}$. The most important properties to be investigated are the elevated temperature tensile properties and the fatigue/crack growth behavior. The thermo-mechanlcal treatment (TMT) w111 siguificantly affect the mechanical properties so that the properties ahould be determined for vartous TMT's. The goal of the prograin 18 the selection of a reference copper alloy for rear-term applications.

\section{C.3.3 Fabrication and Bond Development}

Work should be undertaken to examine the fabrication of plasma side materlals, bonds, and heat-eink materla1s. The properties of duplex structures (plabma-gide materiai bonded to heat sink) are $\therefore$ naxt:ular concern. Duplex structures should be fabricated and the thermophysical and mechanical properties of the bonds should be measured. The goal of this program ts to 1dentify the optinum fabrication procedure for HHFC for near-term applications.

\section{c.3.4 Irradiation Studieg of High Heat Flux Materials}

This program would add 1rradiation danage considerations to the other properties considered in the above programs. The neutron demage level of Interest are $\sim 10-50 \mathrm{dpa}$, and the temperatures of interest are room temperature to $\sim 400^{\circ} \mathrm{C}$. The goal of this program is the selection of reference 
plasna-side and heat-olnk materisis for long tern applications.

\section{C.3.5 Selection and Developnent of Refractory Metals for HEFC}

Refractory netals are at an early stage of development for fusion applications. Work should be perforned to establish fabrication procedures and a baseline data base for these wetals. The petels of interest are tungsten, tantalum, vanadium, nioblum, and molybdenum alloys. Data ts needed in the areas of thermophysical properties, mechanfcal properties, and 1rradiation effects. The temperatures of Interest are roon temperature to $\sim 1000^{\circ} \mathrm{C}$, and the fluences of interest are 10-50 dpa.

D) Thermal-Hydraulies

D.1 Issues

The key issues in thermal hydraulics are:

\section{D.1.1 Critical Heat Flux}

Evaluation of subcooled flow bolling (SFB) crittcal heat flux between 1.0 and $20 \mathrm{mw} / \mathrm{m}^{2}$ for large surface ares $\left(0.1\right.$ to $\left.50 \mathrm{~m}^{2}\right)$ fusion components with large $L / D$ ratio ( 50 to 500 ) coolant channele. The lower range of the heat flux (1-5 MW/ $\mathrm{m}^{2}$ ) appears to be the nost likely for in-vesgel components in future devices if present thermomechanical constraintg asgociaced with high ercsion rates from the plasma-side materlals are not ellninated. The higher heat flux range 1o 1mportant for concept improvemedt. Sowe components such as beam dumps operate at the high beat flux range but success in this aree has been achieved because their operating requirements are significantly less demanding than those of the in-vessel components.

\section{D.i.2 Stability Criter1a}

Establishing the thermal-hydraulfic stabllty arfteria of multiple, intercosnected, and bubchanneled coolant conduits is essential to near-term component design. 


\section{$D .2$ RED}

The prioritized engtneering RdD needs for HHF SFB heat removal are:

D.2.1 Develop uncondtionally stable SFB CHF and pressure loss data for single and oultiple coolisnt channels with $L / D$ ratios between 50 and 500 and with heat fluxes between 1.0 and $20 \mathrm{~mW} / \mathrm{m}^{2}$. Determine the quantitstive effects of gurfactant additives, binary mixturee, owlri ilow, and hellcal subchannels relative to otable axial flow dats.

D.2.2 Perform thermal-hydrauifc stabilicy siudies to examine, e.g.s the Ledinegg, flow pactern transition, parallel channel, and condensation induced instabilities. The fusion component flow-channel design requires such an analysts.

D.2.3 The mechanistic understanding of conditions leading to SFB CHF should be increased by: a) Develoging engineering models for SFB CHF characterizatton which are based on flrst princlples and which relate the applied heat flux to the bulk and local SFA pararaters; b) performing flow visualizations to observe botin hydrodynamic and thermal characterfstics which will lead to an overall underatanding of SFB CHF and provide guldance for engineering model development.

E. Thermomechan1cal Response

\section{E.1 Existing Plagma Experiments}

No critical fasues were identifted for exlating machines with zespect to thermomech.sntcal response.

\section{E.2 Near Term Fusion Experiments}

\section{E.2.1 Bond Integr1ty}

The otructural fntegrity of the attachment interface between the plasmaside armor material and the actively cooled heat sink must be denonstrated. This requires thermal farigue testing of prototype components on ASURF and PMTP, generle component teating on ESURF and EBTF, bond strength and thermal 
conductance data, and 2-D finlte elenant thernal and stress malyges.

\section{E.2.2 Melt Layer Stabl11ty}

Losg of the melt layer due to eddy current forces during a plasma disruptlon must be avolied to prevent excesstpe surface eroston. Laboratory expertments and computer simulations must be performed to assess the severficy of this problem and to factlitate design changes that ay ellatnote the effect.

\section{E.2.3 Fat Igue Crack Growth}

Crack growth leading to a coolant leak or fallure $c \dot{i}$ the plasma-side matertal must be prevented. Baslc data on fatigue crack growth razes in candidate materials and across interfaces to required for computer simulations. Thermal fatigue tasting of intentionally flawed prototype cour ponents should be performed to verify the fracture mechanics anelysis.

\section{B.3 Intermedtaie Pusion Devices}

\section{E.3.1 Bond Integrity}

Neutron radiation damage will degrade the bind between armor and heat sink due to (1) differentlal swelling stress bulld-up, (2) Inpurity traneport to the Interface, and (3) embrittlement. Long-tern Irradiation must be performed In FFT, EBR-II and FMIT on bonded specimens to develop approprtate damage models that can be used in computer simulations of bond fallures.

\section{E.3.2 Erosion}

Surface erosion. Is a critical 1ffetime iesue that directly affects the thermomechantcal responge.

\section{E.3.3 Embr1ttlement}

Neutron-1nduced embrittlement of candidate h1gh heat flux aterials must be understood to avold catastrophle fractures. Fracture toughness meaguremente on Irradiated specimens will allow the use of fracture mechanfcs to provide an adequate safety margin. 


\section{E.4 Deno/Comercial}

\section{B.4.1 Creep/Fat1gue}

The Interaction between creep and fatiguo dange curlug neutron irzadiation nay accelerate crack growth rates and lead to preature fallure. Wore experinental data and odeling is required.

\section{B.4.2 Greep Rupture}

For long-pulse or steady-state fusion reactors, creep rupture mag be the Iife-Ilmiting fallure wode, espectally uader the laflerence of radiation damage. More experfinental data and modeling is required.

\section{E.4.3 Swelling}

Low swelling high heat flux materials must be developed for long-term applications because excessive deformations may prevent easy removal for malntenance and repa1r.

\section{F. Electromagnet1c Response}

\section{F.1 Issues}

In order of prlority the critical tsaues regarding the electromagnetic response of HHFC are as follows:

F.1.i Present eddy-current codes have a limited capabtlity to evaluate eddy" currents in real, non-idealized geometrieg for high-heat flux components. In addition, complicated hetergeneous and composite materlals cannot presently be treated adequatej. 7 .

P.1.2 The overall coupling of eddy-currents in all in-veseel components and their feedback on the motion of the disrupting plasma 10 not well understood, although it is belleved to be oignificant.

P.1.3 The formation and stablilty of melt layera on high-heat flux componenta during a disruption remaing a major uncertainty. 


\section{F.2 BSD}

Accordingly, the following R\&D requirenente have been ldentified.

F.2.1 A 3-D eddy-current code needs to be developed as a component design tool. This code mat provide the capabilitios of treating conposite structures consioting of different aterials with temperature-dependent electrical conductivities.

F.2.2 Th1s code should be integrated with a general purpose, finfte-element stress analysis code; the latter sbould treat magnetic danping.

P.2.3 Stmulation experiments on electromagnetic forces and on welt-layer stablify are essential in order to cest and confirs she above codes and models of the melt-layer stability.

G. Instrumentation and Control

\section{C.1 Key Is}

The key 1sgues have been Identified as follows.

\section{G.1.1 Instrumentation of the "Plasma Side" of HHFC conponents}

This 1.9 an area in need of come development, primarily due to the severIty of the environment in which this portion of the component nust operate and be 1nstrumented, and to the severtig of the 1mpact of any undesired performance or faflure on the plasme and hence device operation. Non-contact, Instru measurement techniques are destrable for ingtrumenting the plasma side of HurC due to advantages of operation $1 n$ the presence of severe $E-H$ and radiation flelds, and the response speeds for control loop application.

\section{G.1.2 Definition of Control Loops and Algort thas Involving BHFC}

Control logic for HHFC needs to be generated for each device during ito conceptual design. Control loops and algorthng are not presently well defined for future devices at any stage. It is important to Identify the reactor control gystess so that they can be fully integrated Into the total design. If englneering data. for control algorithm generation is not taken on 
derlces 11ke TFTR, the lack of ouch data could becone a critical problem.

\section{G.1.3 Radiation Hiardening of Instrunentation and Contro1 Syateras}

Upgrading io necessary to provide radiation hardened data acquisition and control systems and interfaces which can perform rellably in the severe electronagnetic and radiation fields of future devices. Such items as optical windows, lenses and mirrrrs, fiber optics, and electronics are particularly susceptible to radiation environments, and existing devices are not generally destgned for operation in high neutron fluences.

\section{G.2 R\&D}

The associated RED needs are listed below.

\section{G.2.1 In-S1tu Inetrumentation}

(a) Development of measurement techniques for in-situ erosion and redeposition rates and the spatial distribution of these rates. This developreat effort past address the integration of the measurement system with the operating fusion device.

(b) Development of Improved techniques for non-cantact surface temperature measurements in the presence of a D-T plasma. Thls may Involve upgrading of IR systems to reduce or elfminate the impact of emlssivity changeg of the object (primarliy due to surface condition changes, although wavelength and temperature depentence need to be addressed) and transmission/reflectance changes of optlcal components (1.e., redeposition coating of windows and radiation damage to windowe/mirrors/photosenaltive devices. This development effort must also address full integration with the 1ntended fusion device.

\section{G.2.2 ControI}

(a) The ablitty to test HHFC control schemes should be Incorporated into future device designs so that some of these techniques can be incorporated into the standard control logfc of devfces such as ETR and DEMO.

Th1s should include both control of HetF parameters and contributions of HhPC to the total reactor control scheme, which involve long term drift compensation of plasma parameters, gross device parameter adfustment, and 
Interlock/alarm functions.

(b) Development of contro1 algorithng for device oubsyotem control will rely heavily on results from extoting devicea. Bxisting devices and thuir follow-ons should include tests which provide an engineerlag data bage for control algorithn generation.

\subsubsection{Radiation Hardentag}

(a) Define and perform experiments which will provide a data base for radiation effects (fugion-specific radiation environment) on HHF instrumentation componente.

(b) Place more emphasis in device designs thteh address I\&c radiation hardening (1ncludes I\&C des1ga, placement aui shielding). 


\section{SOURCE CONDITIONS}

\subsection{Introduction}

The design of components to be used in high heat flux regions of fusion devices depends critically upon the operating conditions those devices will experi-ance. These operating conditions include not only the heat and particle fluxes but also the electric and magnetic environment aruind the component. As the input power and pulse lengths of devices have increaged, designars have been forced to pay more attention to operailing conditions. This has fostered more diagnosis of the plasma edge and resulted in somewhat better understanding of the plasma edge. There remalns much to be done before the level of usderstanding is adequate to provide the detalled understanding necessary to design components for advanced devices, but there is time to obtain this understanding.

There are three major groups of components for which iperuiting conditions must be defined. The firrt group are those components which are in direct contact with the plesma, such as 11 mlters or divertor plates in tokamaks and halo sctapers, collector plates, and dicect convertors in mirror machines. The second group are those componente associated with auxtliary heating, such as beam dumps, wall armor, grids, and RF windows. Finally, there are first wa11 components. Witle some components fall into more than one group, there is always a primary function that is in one of the above groups. The auxiliary heating group has the best defined operating conditions. Those components In direct contact with the plasma have the greatest uncertainty in the operating conditions. The operating conditions of the first wall are well: defined theoreticaliy, but there is no dirent experimental support for the calculations because reactor relevant conditions have not yot been achieved. The input to the codes change as more is learned about plasma condictons, resulting in a good deal of uncertainty in the firct wall conditions.

Th1s chapter will cover four major toples in regard to the environment of the three groups of components. Section 2 will address the present state of the data base that exigts on present machines. Section 3 will briefly discugs the theoretical understanding of that data base. Section 4 will look at predicted conditions for future devices. Finally, sect ton 5 w111 discuss what is needed to improve the understanding of operating conditions and, hence, reduce the uncertainty 1 th the predictions for future devices.

$$
I=1
$$




\section{I.2 The Data Base on Present Devices}

This section contains a brief description of the diagnostics ubed to measure properties of the edge plasm and the performance of components used in high heat flux areas. The typlcal operating condtions derived from these diagnostics are then sumpartzed. The section concludes with a discusstion of the qualtey of thts data.

\section{I.2.1 Diagnostic Techniqueg}

D1agnostics that are used to determine condtions in the plasma edge isve improved greatly in the past few years. The traditional Langmuire Probe has been Improved by the use of better equipwent and new techniques such as criple probes. The use of Langmuire probes was recently reviewed by srafb: Probes are In use on Alcator-C ${ }^{(2)}, \mathrm{PLT}^{(3)}, \mathrm{PDX}^{(4)}$, and $\mathrm{TFTR}^{(5)}$. Thase traditional probes have been supplemented by calorimeter probes $(6)$ which directly measure the plasma power densfty in the edge. Power flow to 11miters and divertor plates, and energy scrape-off lengths have been inferred from the time depeädence and spatial distribution of surface temperature measured using Infrared thermography (8-11). These Infrared techniques are also applicable to beam dumps ard similar components. Calorimetry done by water flow and $\Delta T$ is done on many devices to determine total energy deposted on a device. Thermocouples and thermistors are also widely used to measure operating temperatures ant to calibrate the infrared diagnostics. Hydrogen recycling and impurity transport in the edge region are important to operating conditions, but a discussion of all the diagnostics associated with these phenomena ts beyond the scope of this chapter. The interested reader is referred to the excellent review article by McCracken and Stott (12).

\section{2.2 Operat 1ng Conditions in Present Devices}

The operating conditions that are deduced from the data provided by the diagnostics mentfoned above are listed in Table I-1. In several cases, the figures are only estimates made by those working on the particular device. ine zost striking feature of the table is che wide range of values. A significant number of these variations are due to the differences in geometry In the vartous machines. The geometrical differences are both in the size and 
Table I-1. Operating Conditions of Existing Devices

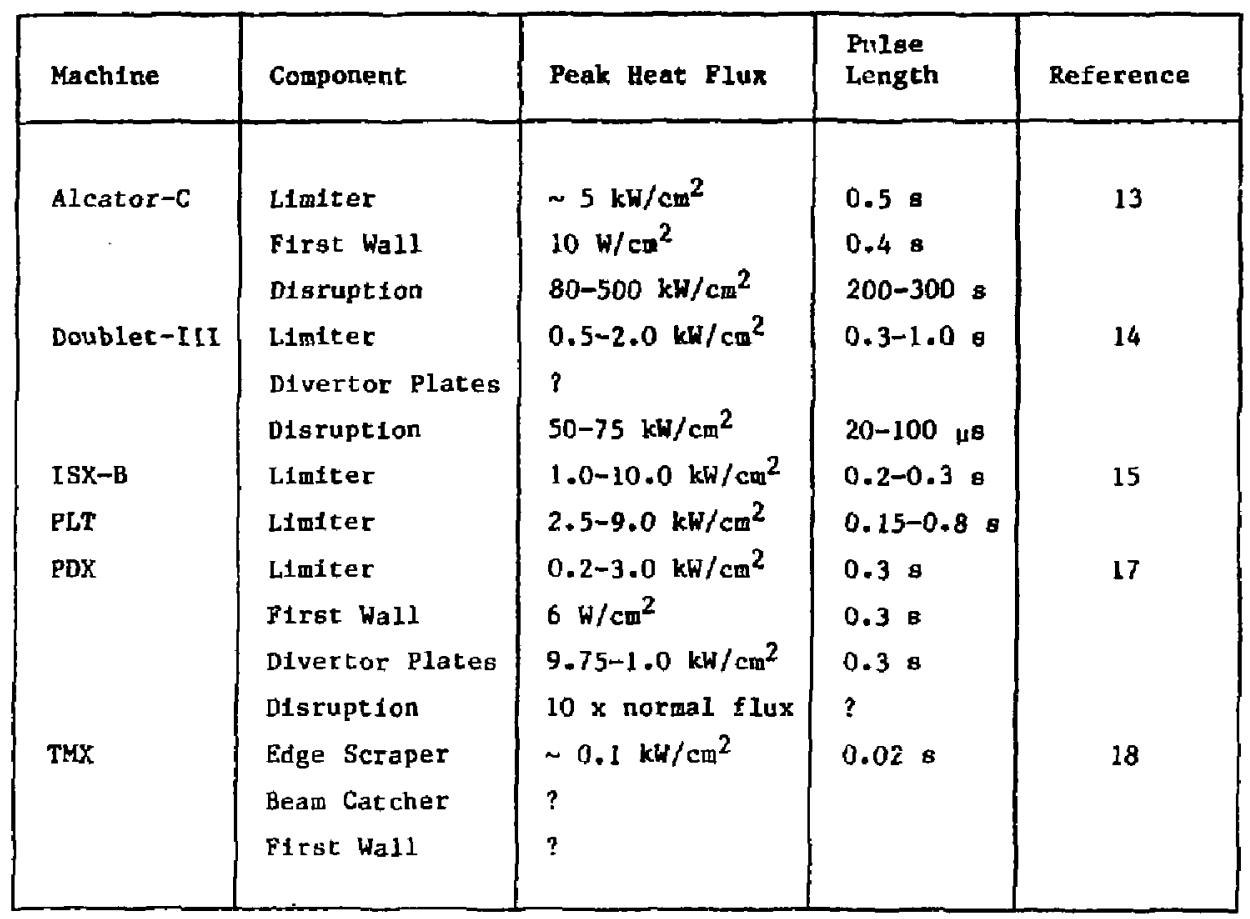


shape of the conponent as well as changes in plases paraneters rebulting fros different configuration, e.g., the connection length is shorter for an axisymetric liniter than it is for a oinple rail liniter wich results in different scrape-off lengths and different power loads. Other variations are due to different magnetic flelds, auxilisry heating power, and impurities. While many aspects of the plasia edge are underatood, there is not a complete understanding of the edge physics. The loads on the "first wall" are determined from bolometric measurements of the radiated power.

There is an additional IIne in Table I- 1 for the tokanak devices dealing with the conditions during fault conditions ouch as disruptions. These fault conditions are characterized by two phases: a theral quench phase during which the plasma cools, followed by a current decay phage during shirh the plasma current disappears. The first phase results in large heat loads to the limiter or divertor plates. The second phase regults in large electromagnetic forces on internal components. The time scale on which the current decays in various devices is shown in Fig. I-1. These fault conditions are most common when plasma conditions are being pushed into new regimes. They are, therefore, to be expected for the beginning phase of any device that explores new plasida conditions.

The operating conditlons for auxlliary heating components are also shown in Table I-1. The variations in these numbers are completely explafned by differences in geometry and/ar source parameters. There are some small differences that are caused by plasma parameters, but they ate not a major effect on the operating conditions.

\section{I.2.3 Discusslon}

While there is a significant amount of data on the plasma edge at this time, there are several shortcomings. One is the lack of a complete set of data about all processes in the plasma edge. This results in an incomplete understanding of the physics of the edge plasma. We also do not know how the edge parameters will acale as conditione become more reactor-11ke. Th1s would probably even be true if our understanding of present edge conditiong vere complete. This means that future devices will have to be designed to accommodate a range of operating conditions. Thus, it 1s of critical importance to continue to otudy the plasma edge in order to reduce this 


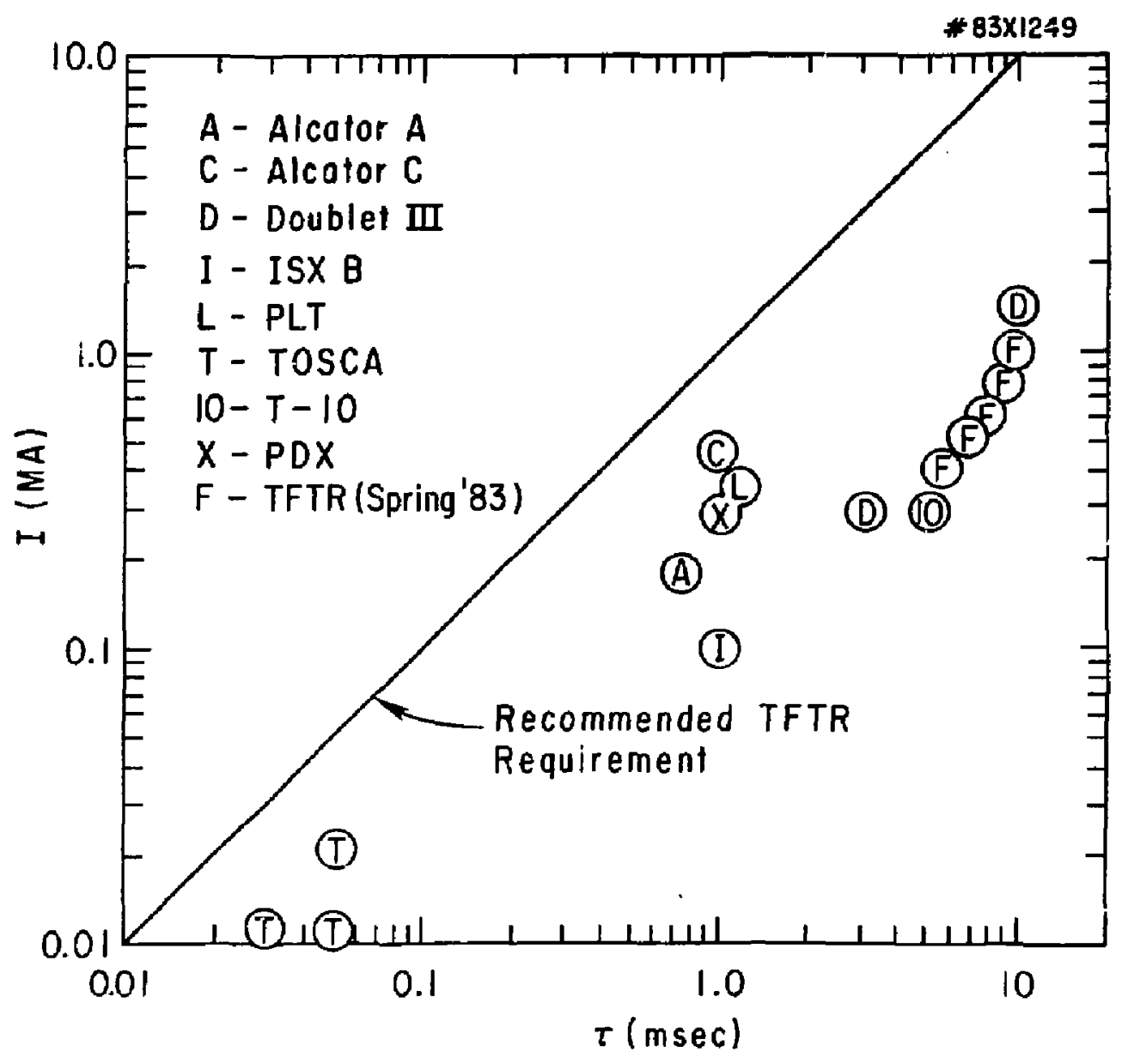

Figure I-1. Time scale on which current decays in varlous devices. 
uncertainty. Since plasma conditiong will continue to be pushed into new regimes, the fault conditions in tokemaks will also have to be considered as discussed above.

The heat loedg on beam jumps, wall armor, and other auxtllary heating components 19 very well underatood at this time. The data that we have now also extrapolates very we11 to future machines. Most of the work that must be done for such components is to Improve pulse lengths, develop new oources, and account for differences in machine geomercy. Even for new sources, the operating conditions should remain well defined.

As mentioned above, the operating conditions of the first wall in current devices are not necessarily representative of reactor devices, This problem is only solved by making more reactor-relevant devices such as MFTP, TRTR, or TFCX.

\section{3 Theoret 1 cal inderstanding of Opexating Conditions}

The extrapolation of the data on edge plasma conditions in current machlnes to future devices depends strongly on a theoretical understending of the physics behind such conditions. In a large part, the certainty of the operating conditions for beam dumps, wall armor, etc, is due to the theoretical understanding of the physics lavolved in the hat source and power transport. Th1s section wil examine the models used to understand the edge plasma and their application to predicting conditions for high heat flux componer,ts.

The plasma edge Involves a complex Interaction between several Important effects. The eransport of particles and energy in the edge depends on the electron and fon temperature profiles, magnetic field, neutral denstty profile, recycitig coefficients, plagma thermal conductivity, particle diffustuity, tmpurity species and density, impurity generation rates, and atomf and wolecular cross sections. There are several sophisticated computer codes that can solve the plasma transport equations Including all of the above effects with many optiong. One such code that Includes the edge Is the BALDUR code(19). Host of these codes are one or one-and-one-half dimenstonal. They can partially duplicate such effects as the "H-mode." There are several twodimensional codeg $(20,21)$ that have been used to describe plasma transport into divertors and pump Ifmiters, but they are not as rigorous as the one- 
dinensional codes in their treatment of the physical processes in the edge. Fot the FED/INTOR studies, several oimle one-dimensional codeg $(22,23)$ were used to predic: plasma conditions. Kost of these codes have been compared to data taken from present wachfnes and with each other. In all of these codes, assumptions must be made to make the problem tractable or to model unknown or poorly understood effects. In all caseg, the nature of the assumptions strongly influences the values of the plasma transport coefficlents that explain the data. Therein lies the primary source of uncertainty in predicting operatiog conditions in furure machipes. There are also a vast array of codes to calculate spectic parts of the edge problem such as the neutral density profile or sputtering yleld. In wany cases, these specific codes are used by the large codes. The charge exchange flux to the firat wat1 18 also predicted by the same codes. This is very important for first wall designs.

The heat flux to beam armor or simflar components is calculated using codes that include the source grid geometry, electric and magnetlc flelde, space charge, gas pressure, the presence of scrapers, and the plasma attenuation. These codes are very specific to a given source type. They have been very carefully calibrated and give excellent results.

\section{I.4 Predictions of Operating Gondtitions for Puture Machines}

The codes discussed above have been used to profect operating condittons for devices that are just beglnaing operation, or under construction, as well as longer term devices such as TFCX, INTOR, or MARS. Table I-2 lists the results of such predictions. Th1s table does not list every device which has been considered, but it does contain a representatlve sample of the general classes of devices that have been studied. In general, those machines which are the closest to belng constructed (or actually under construction) have recelved the most careful consideration in cerms of evaluating the uncertalnties and are lso the closest to present edge conditions. Predictiona for long-term devices like DEMO are not adequate to do a detalled design of such a device, but data from intermediate machines will solve that problem. It 1B interesting to note that wost of the peak heat fluxes for componente in contact with the plasma are below $5 \mathrm{mw} / \mathrm{m}^{2}$. This is in part due to the perception chat this is an acceptable steady-state heat flux. Devices 
Table I-2. Predicted Operating Conditions in Future Devicea

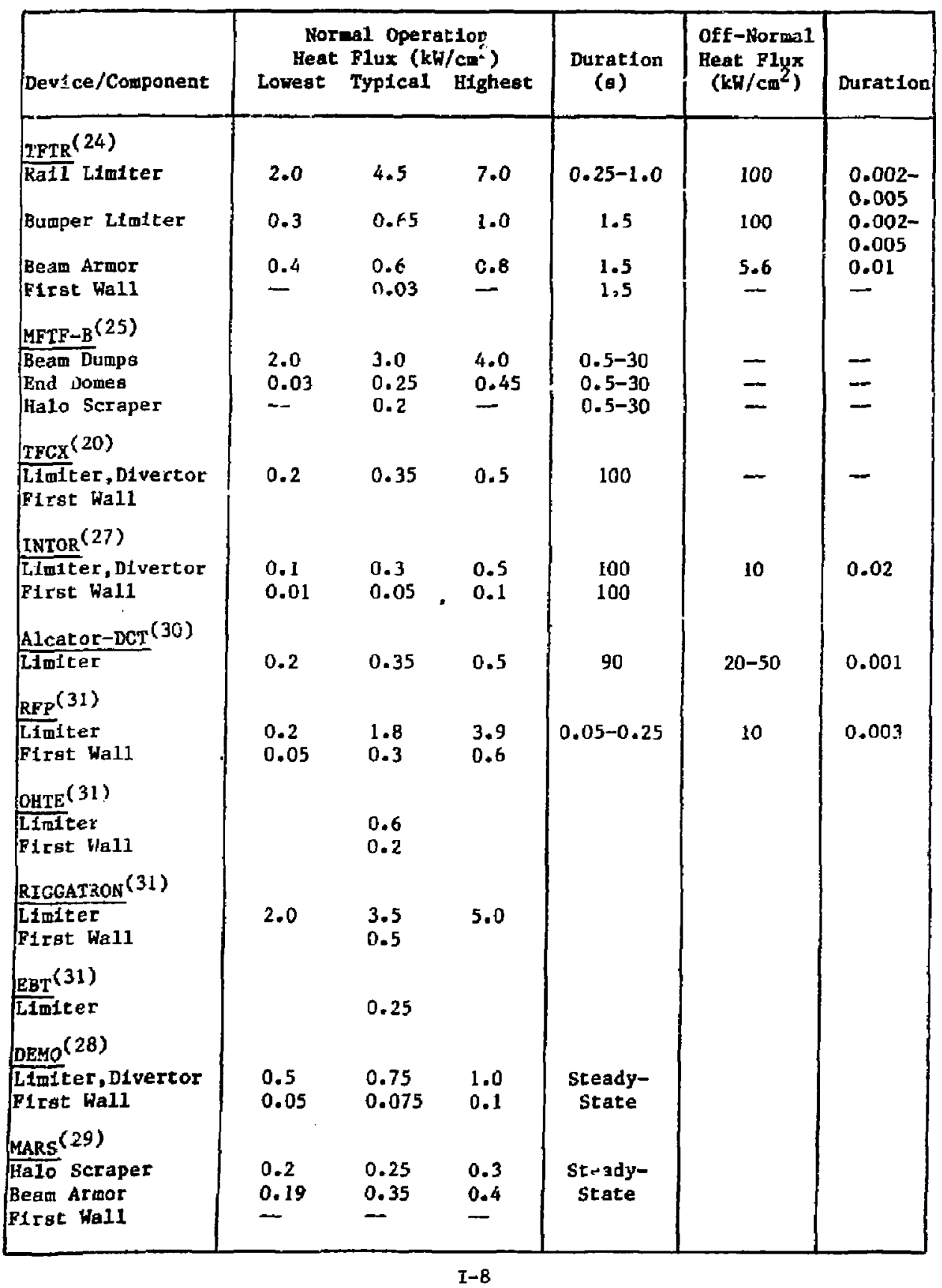


having a shorter planned 11fetime, such as the compact torl, have the highest predicted heat fluxes. This $1 \mathrm{~s}$ the regult of a trade-off betwees ilfetime, peak, heat flux, and machine size. The heat fluxes for bean dumps are higher but the uncertaintles are smaller and such devices are not in direct contact wth the plasma. Impurity levels have a atrong influence on operating conditions, and 1mpurity control 16, thus, very inportant.

\section{I.5 Assessment of Operating Conditions and Future Needs}

The following conclusions can be reached from considering the present stace of knowledge concerning operating conditions.

- Recent developments in and attention to edge plasma diagnostics have fostered a better understanding of the plasma edge.

- Theoretical understanding of the edge ts keeping pace with the data base.

- Infrared temperature diagnostice are shedding 1 ight on the Interaction of the plasma with high heat flux componente.

- Operating condtions for suxtllary heating components are well underatood. 


\section{REFERENGES POR CHAPTER I}

1. P. Stalb, J. Nuc1. Mater., 111 \& 112, 109-122, 1982.

2. E. Marnar, private comunication.

3. D. M. Manos, R. Budny, T. Satake, S. A, Cohen, J. Nucl. Maiter, 111 \& $112,130-136,1982$.

4. R. Budny and D. M. Menos, Princeton Plasma Physics Laboratory Report No. PPPL-2065, 1983 .

5. D. K. Manos and P. C. Stangeby, private communfcation.

6. P. C. Stangeby, G. M. McCracken, J. E. V1nce, J. Nucl, Mater., $111 \& 112$, $8 I-83,1982$.

7. W. R. Wampler, D. M. Brice, C. W. Magee, J. Nuc1. Mater., 102, 304, 1982.

8. M. Ulrickson and H. W. Kugel, Princeton Plasma Phgalcs Laboratory Report No. PPPL-2041, 1983.

9. B. K. Befn and E. R. Huller, J. Nucl. Mater., 111 \& 112, 548-553, 1982.

10. A. E. Pontau, W. B. Gauster, A. W. Mullendove, R. W. Conn, S. P. Grotz, S. Talmade, R. J. Taylor, J. Nucl. Mater., 111 \& 112, 287-293, 1982.

11. T. Taylor, N. Brooks, K. Iokf, J. Nucl. Mater., 111 \& 112, 569-572, 1982.

12. G. M. McCracken and P. E. Stott, Nucl. Fusion, 19, 889-981, 1979.

13. B. Lipschu1tz, private commanication.

14. D. L. Sevier, P. H. Trester, G. Hopkins, T. E. McKeIvey, T. S. Taylor, J. Nuc1. Mater., $103 \& 104,187,1981$.

15. P. Mioduszewskt, private communfcatfon.

16. S. A. Cohen, R. Budny, G. M. McCracken, M. U1r1ckson, Nuc1. Fusion, 21, $233,1981$.

17. R. J. Ponck, et al., J. Nuc1. Mater., $111 \& 112,343-354,1982$.

18. R. Molr, private comunlcation.

19. J. M. Ogden, C. E. Singer, D. E. Pogt, R. V. Jengen, F. G. P. Seldl, IREE Trans. Plasma Sc1. PS-9, 274, 1981.

20. D. Helfetz, D. Post, M. Petravic, J. We1she1t, G, Bateman, J. Comput. Phys., 46, 309, 1982 .

21. M. Petrav1c, et al., Phy g. Rey. Lett., 48, 326, 1982.

22. H. C. Howe, Oak RIdge National Laboratory Report No, ORNL/TM-7803, 1981.

$$
\text { I-10 }
$$


CHAPTER I

SOURCE CONDITIONS

Lead Author:

M. A. Ulr1ckson (PPPL)

Contributors:

J. N. Downting (LANL)

J. D. Gordon (TRW)

B. Lipschultz (MIT)

R. Mo1r (LLNL) 


\section{REFEREHCES FOR GRAPTER I (continued)}

23. M. vlrickson and D. Post, J. Yac. Se1. Technol., AL, 907, 1983.

24. J. L. Cecch1, J. Huc1. Mater., 93\&94, 28-43, 1980.

25. R. Molr, privace communtcation.

26. J. L. Cecch1, private communication.

27. INTOR Phase II-A, Part 1, Chapter VI and VII, IAEA, Vienna, 1983.

28. M. Abdou, UCLA private communication baged on STARFIRE design.

29. -Mirror Advanced Reactor Study Interim Design Report," Laurence Livermore Nat Ional Labotatory Report No. UCRL-5333, 1983.

30. B. Lipschultz, MIT Plagma Fubion Center Report No. PFC/RR-83-18, 1983.

31. J. Down1ng, LANL private communication. 


\section{I. SYSTEHS INTEgRATION}

\section{II.1 Introduction}

For purposes of discussing systems integration aspects of high heat flux components (HHFC), magnetic confinement fuston reactor concepts will be separated Into three cacegories: two mainline concepts--tokamaks and tandem mirror reactors--and a fleld of alcernative concepts. As 1llustrated by the paraweter tables in Chapter I, the types of HHFC needed and the requirements imposed on those components vary wldely sinong the three reactor categories, and within each category as well when the range of needs from present-day experimental devices through power reactnrs are considered.

High heat flux components are required at many locations thróghout fusion experimental devices and power reactors to perform a variety of functions. Most components are located tn areas with $11 \mathrm{mited}$ access aud must operate for long perlods without fallure. The number of cycles and heat flux level strongly affects the time between cequired replacements. Materials choices are drivea by restraints on plaswa contamination, radiation damage, and lopinging particle flux and energy levels. All components must operate in a high quality vacuuw whlch implies very low leak rates $\left(\approx 10^{-8} \mathrm{std} \mathrm{cc} / \mathrm{s}\right)$. Additional factors affecting the iesign of each component are energy recovery requirements, method of structural support, and design integration requirements for other reactor stbsystems.

Although there are a large number of different HHFC components required for each reactor type, only the more Important ones will be discused in the following sections. The fssues and Rob needs indicated for these components are expected to be valld for the remaling components as well.

The remainder of this chapter concerns the description and lacation of HAFC for each of the three reactor types (Sec. II.2), discussion of the most important systems Integration considerations affecting HHFC designs (Sec. II.3), and a brief listing of key Issues and related R\&D needs (Sec. II.4).

\section{II.2 HHF Conponents Location and Description}

The environment for plagma-facing HHFC in tokamaks is relatively severe. For most profected plasus conditions, surface heat fluxes and particle fluxes 
will be high. Solutions are needed for these problemg that will also be satisfactory from the standpoints of economics and safety. The problems for spectfic Harc are discussed below.

\section{I.2.1.1 Pirat Wa11}

The first wall of a tokamak is exposed directly to the plasma. The basic first wall is shown in FIg. II-1 for both a divertor and pumped limiter configuration.

Active cooling of tokamak first walls will be required for devices beyond TFTR. Water coolant has often been proposed $(1-3)$ for these devices. As an example, F1g. II-2 illustrates typical structural configurations proposed for FED. In present devices such as TFTR and Doublet III, the first wall has generally been fabricated as an ent1ty separate from any shlelding atru ture. In future devices where tritium breeding is required, it is 1ikely that the first wall will be made as an integral part of the tritlum breeding blanket to reduce first wall thickness and decrease neutron capture. Th1s integration results in a number of fmportant design constraints for the first wall, e.g. added restraint to thermal expansion.

There are often other HHFC attached to the first wall, and Iocalized areas requiriag spectal atcention as discussed below.

Protective Armor - Protective armor 1s used to procect the first wall against damage during plasma disruptions or from neutral beam shine-through. The TFTR utilizes bumper limiters at the plasma finterior to absorb the energy of a plasma perturbation or disruption. The protectfve plates at the plasma exterior are used to protect against neutral beam shine-through. These locations are indicated in Fig. II-3 for TFTR in a cutaway view of the vacuum vessel. The design utilizes IIC coated graphite tiles mounted to a water-cooled support panel. Some typlcal armor actachment methode are shown in Ftg. II-3.

Posicioning Lijiter - In near term machines such as TFTR, a positioning limiter is used to locate the plasma. In TFTR (4) this is accomplished by the Iimtter shown in $\mathrm{F} 1 \mathrm{~g}$. II-4(a). The conceptual design for a moveable startup IImiter for $F E D$ is shown in Fig. II-4(b). This limiter genera1ly recelves the most severe heat loading of any HHFC in the device. 


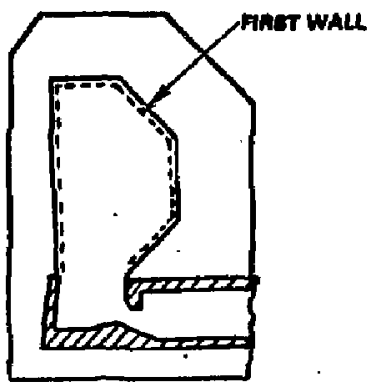

DIVERTOR

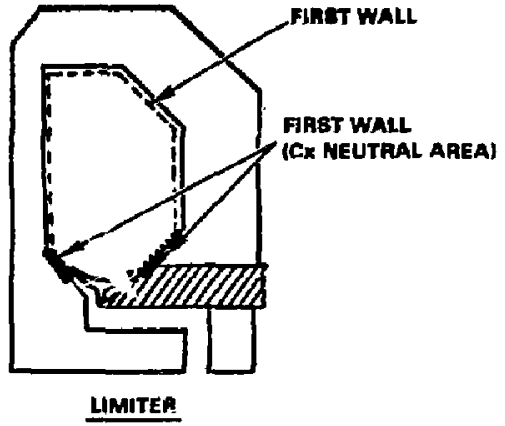

F1g. II-1. Tokanals f1rat wall locetion.

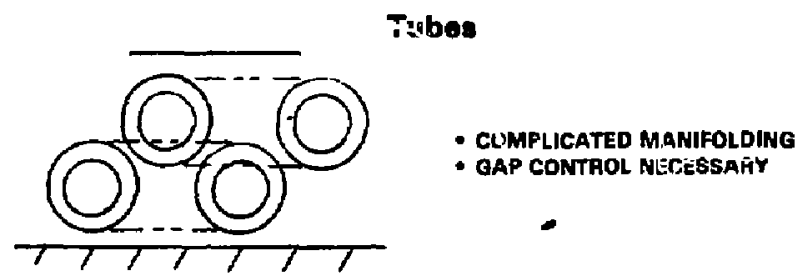

Ribbed Panei

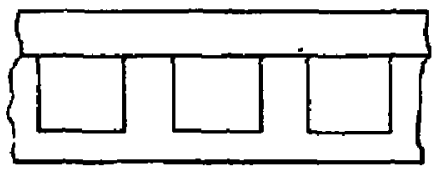

- STRAIGHTFORWARD MANIFOLD

- SIMPLE fagrication

- maXiRuM paNel STIFFNEsS

\section{Embosr jd Panel}

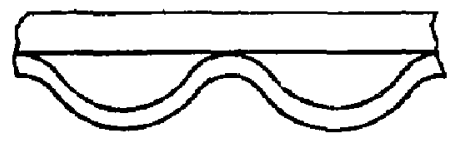

- eihPlest fabrication

- pANEl stiffNEss less ThaN RIBBED

F1g. II-2. Example of configuration for water-cooled firet wall. 


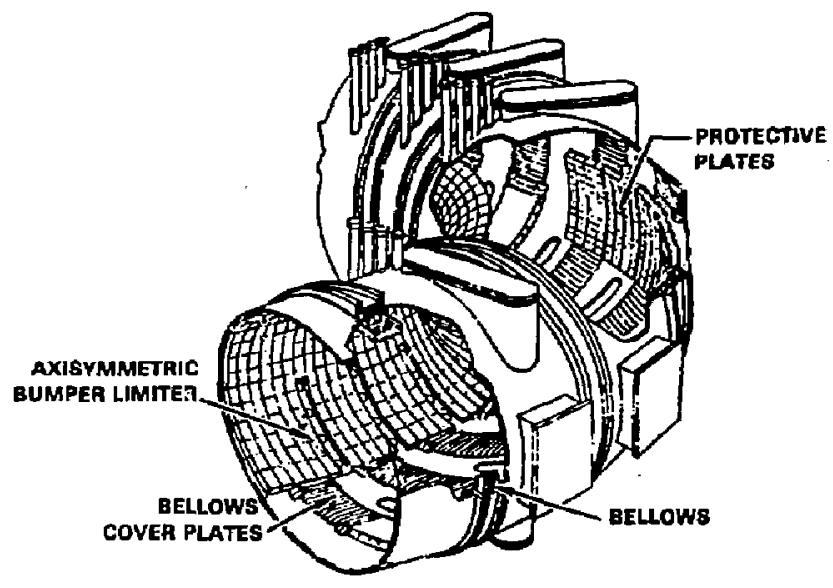

PASSIVELY COOLED ARMOR TILE

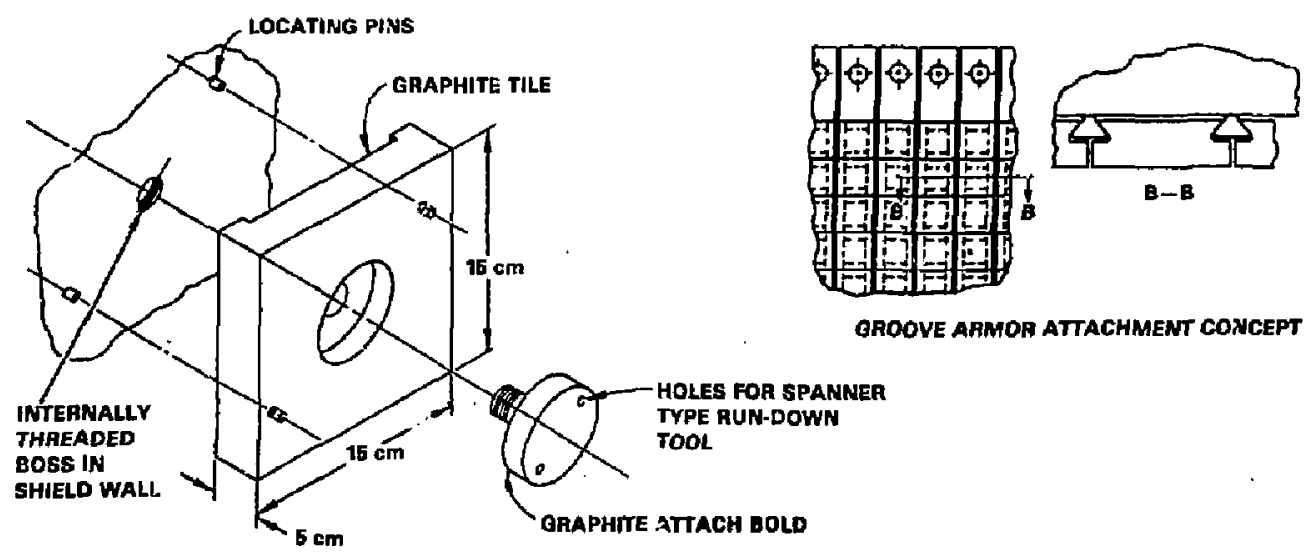

F1g. II-3. Examiples of armor for tokamak firat waII. 


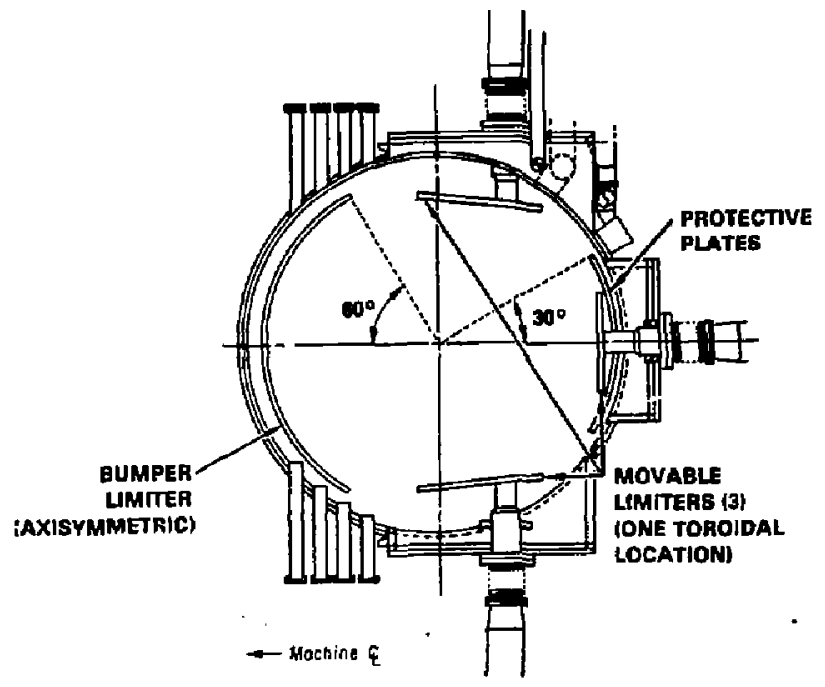

(a) Poaltioning 1imiters in TFTR.
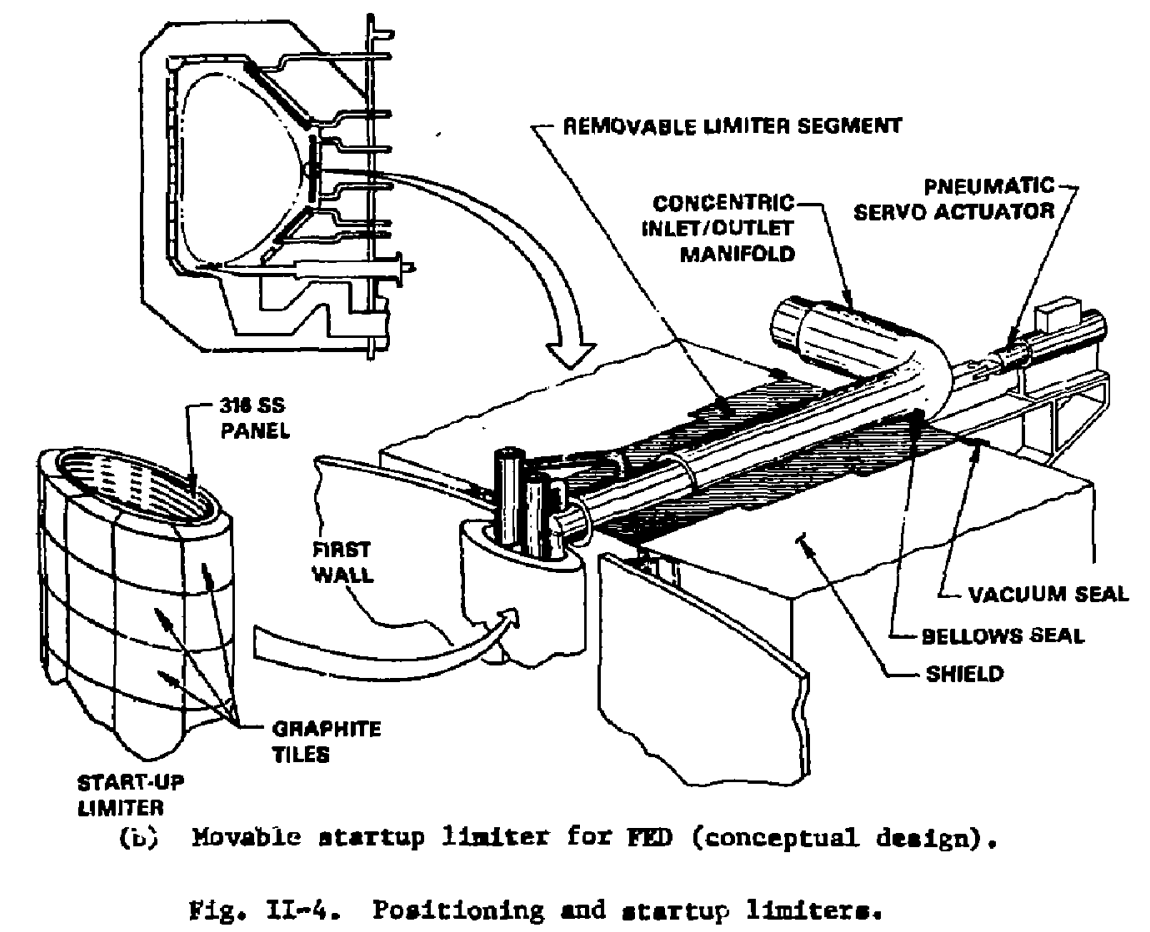
GX Areag - Firat wall areas near the divertor and pumped limiter are subjected to Increased erosion and higher surface heat fluxes due to a higher concentration of charge exchange (CX) neutrals. These areas are noted in FIg. II-1.

\section{I1.2.1.2 Impurity Control}

Pumped 11ulters and pololdal divertors (single- and double-null) are beling consldered for impuricy control. Each system requires high heat flux components for removing the energy from the impurities.

A typical single-null divertor de日ga is show In FIg. II-5. It consists of an inner place and oucer plate that are alfgned to intersect with magnetic field lines from the plasma. The angle of incidence determines the heat load the plate must absorb. This angle ls limited by the ability to tallor the magnetic field: The plate is subject to erosion from 1mpingment by energetic particles from the plasma and generally incorporates a sacrifical protective surface (Fig. II-6). This surface is generally concelved to be a low $z$ material such as be or $C$. The substrate is generally copper, vanadium or ather materfal with relatively high thermal conductivicy. The coolant is cypically water.

A pumped limiter design for INTOR is shown in FIg. II-7. This particular desisn is lacated at the bottom of the plasma chamber and consists of a double-edgeo heat absorption surface. The leading edge is moved away from the plasma to reduce heat load and limit the throughput of the vacuum system. Materials considered for the limiter are generally the same as for the divertor plate.

\section{II.2.1.3 Beam Dumps}

Neutral beam heating of the plaswa requires that fons be stripped from the beam and absorbed in a vacuum pumping system. The fons strike a surface that absorbs their energy. This surface must be actively cooled. The location of an lun dump in a neutral beain test facllity is shown in Fig. II-8. Designs that have been used for this heat absorbing surface laclude swirl tubes and flat plates. The flat plate design shown in Fig. II $\rightarrow 9$ can absorb $3000 \mathrm{w} / \mathrm{cm}^{2}$ continuously. 


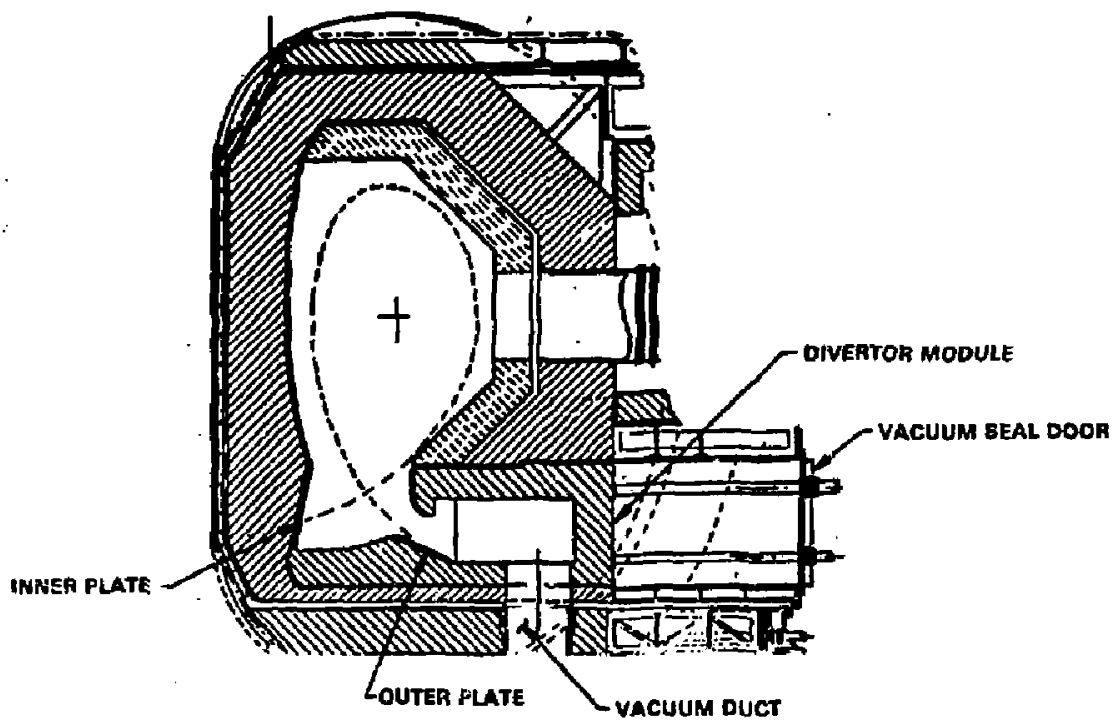

F1g. II-5. Typteal eIngle-null pololdal divertor configuration.

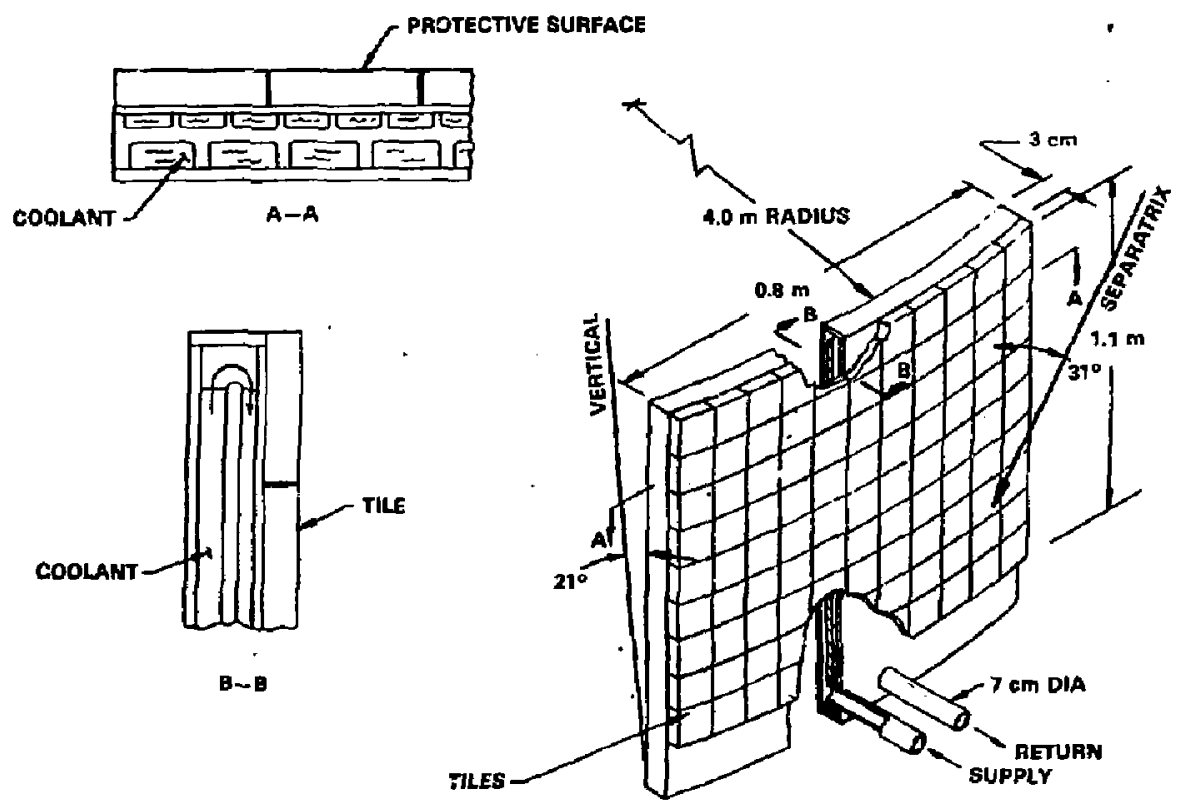

P1g. II-6. Inner divertor collector plate cosfiguration. 

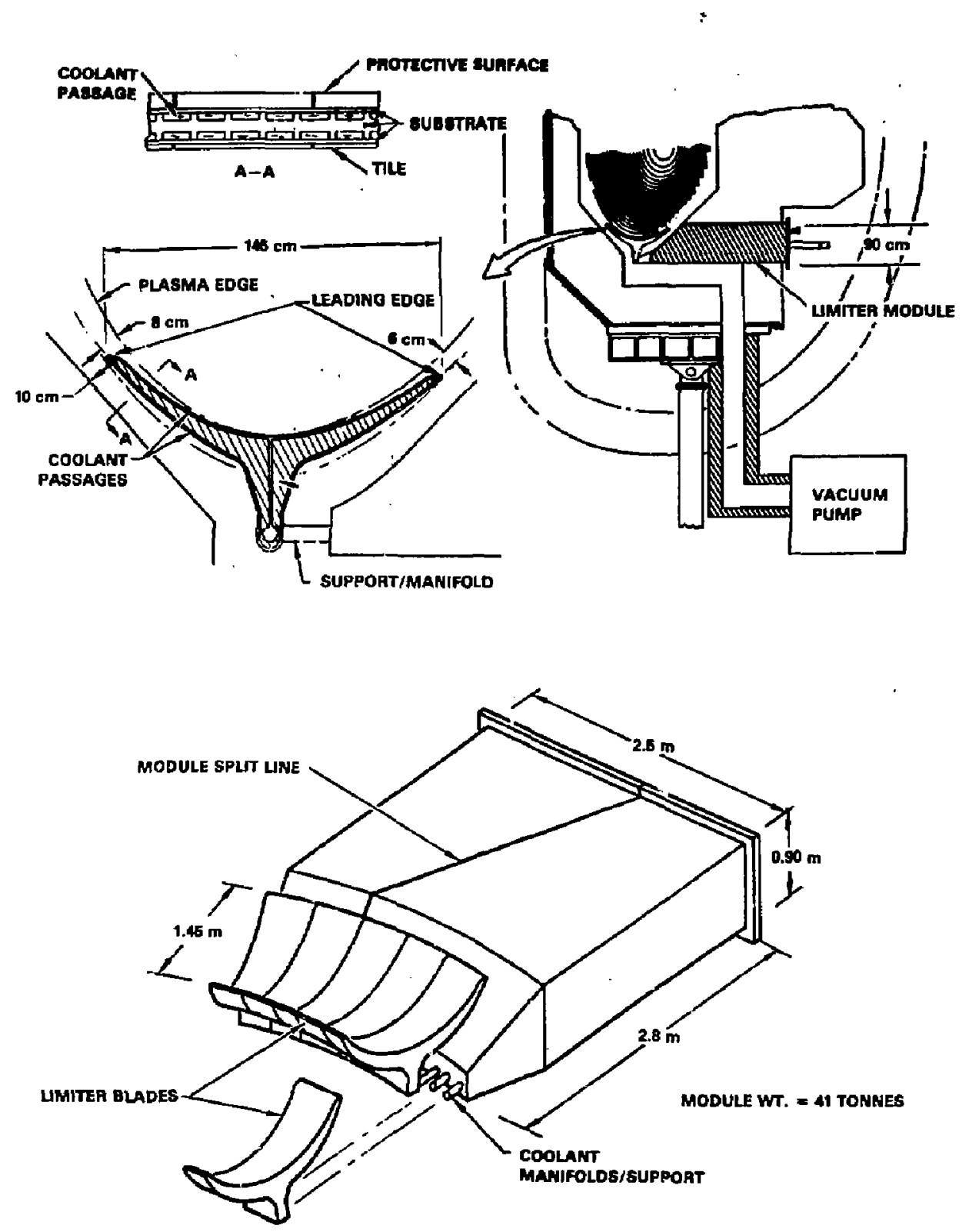

FIg. II-7. LImiter configuration (1982 U.S. INTOR reference desIgn). 


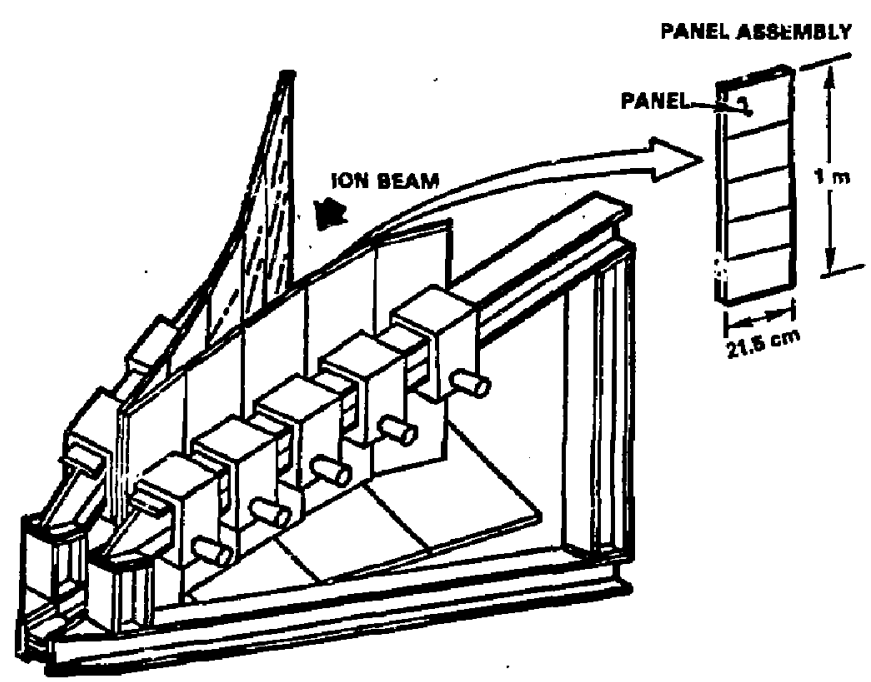

F1g. II-8, Neutral Beam EngIneering Test Fac1lity (NBETY) 1on dump.
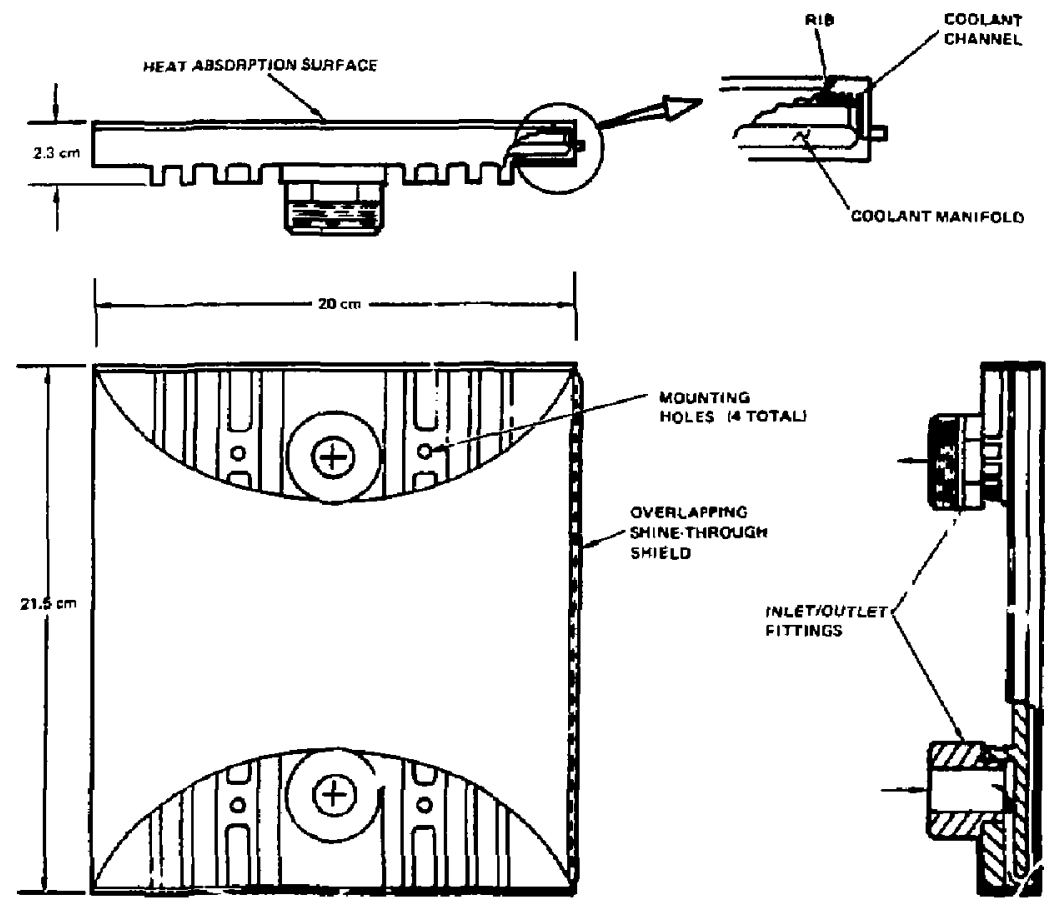

FIg. TI-9. Actively cooled heat aboorption panel for NBF.TF. 


\section{II.2.1.4 Ion Source Gridy}

Neutra, beam ton sources utilize a grid rall gyotem to direct the particles. These grids must absorb large heat fluxes. Although current neutral beams are operated in a pulsed mode, beams in the future must be designed for continous operation. The accelerator source grid uged in the TFm ion sources is shown in F1g. II-10.

\section{II.2.1.5 RF Antennas}

RF antennas must be located close to the plasma for effective coupling. Thus the antenna system must absorb energy levels comparable to those for a limiter. A system used for EBT-S 1s shown in F1g. II-11. It constats of a loop antenna radiating element and a Faraday shield. The loop antenna must absorb $-50 \mathrm{w} / \mathrm{cm}^{2}$ but the Faraday shield 15 exposed directly to the plasma.

\section{I.2.2 Tanden Mirror Reactors}

The tandem mirror is an Inherently steady-state device with an open magnetic configuration. These two characteribtics have an influence on the requirements for high lieat flux components, thetr location in the device and on their design.

\section{II.2.2.1 Beam Dumps}

Beam dump requirements for tandem mirrors are predicted to decrease as the systems evolve, for several reasons. Flrst, the rellance on beams is decreasing. MFTF-B uses beams for plasma heating, charge axchange pumpling and denstity peofile control. In the reactor configurations, only a sloshing fon beam for density profile control is needed. Moreover, the particle energles are Increasing. This causes the same power to be delfizred at lower current which slmplifteg the design. Development work has been "zae on molybdenum and vanadium-coated copper dump up to $8,000 \mathrm{~W} / \mathrm{cm}^{2}$. How sloned, copper or AMZIRC dumps are preferred. The ifFTF-B $(5)$ has short pulses of 0.5 to $30 \mathrm{~s}$. The dumps are desigaed for $5 \times 10^{4} \mathrm{cycles}$. All tater wachines w11l have a much lower number of cycles. Other beamline components, notably collimators, will be subject to moderately high heat fluxes of $<1,000 \mathrm{w} / \mathrm{cm}^{2}$. 


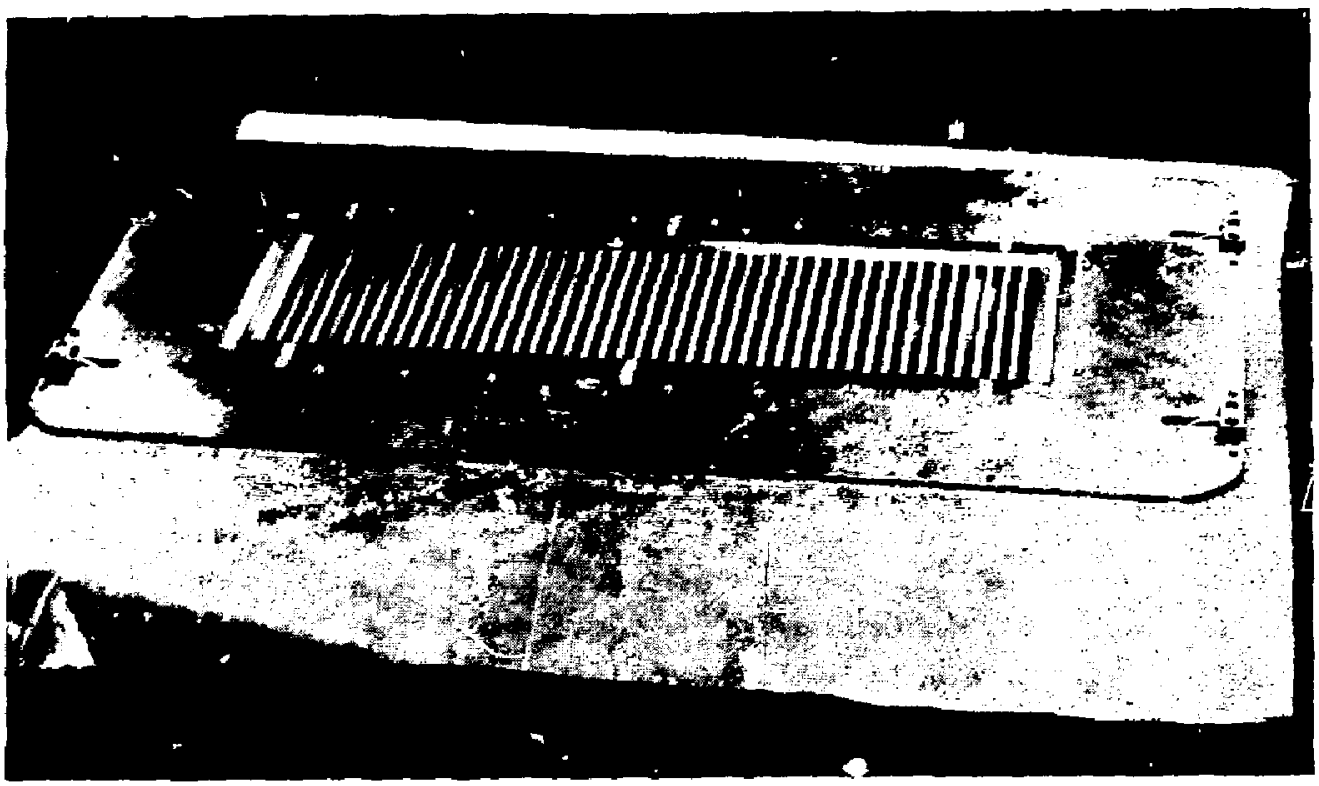

F1g. II-IO. TFTR accelerator source grid assembly.

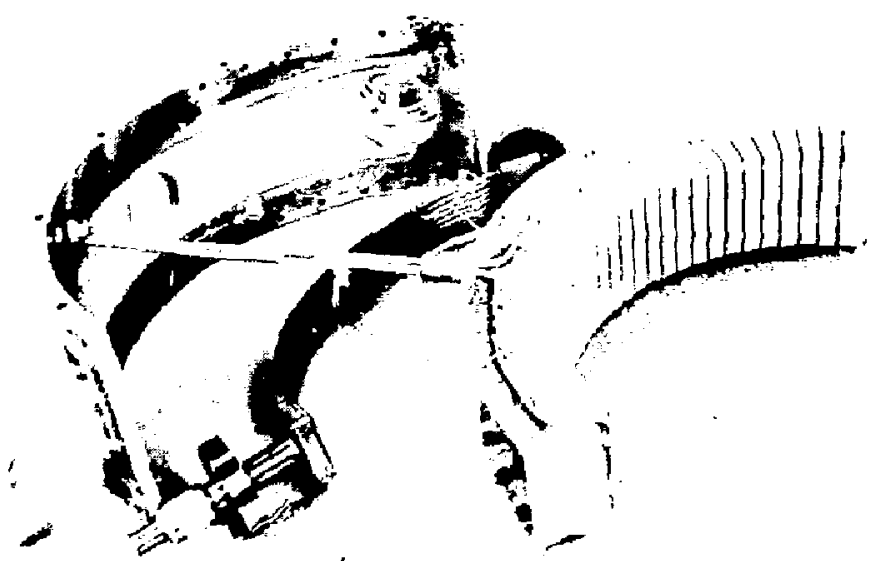

Fig. IT-11. EBT-S ICRH antenna. 
Figure II-12 shows the layout of one version of MFTF-U(6), a beam-driven wirror without charge exchange punping. Each bean has both an Internal (lon) and external (neutral) dump. Schematice of external and Internal dump are shown In FigB. II-13 and II-14 respectively. The cross section of an Internally-fianed, water-cooled copper dump is shown in F1g. II-15. In all degigns, the option exists to angle the dump with respect to the Incidence angle of the beam. Th1s lowers the heat flux but ralses the sputter rate.

\section{II.2.2.2 Charge Exchange Aress}

Charge exchange from low energy beams causes a distributed flux of energetic neutrals on the walls near the injection point. The angular distribution of these neutrals depends on beam energy and plasma density. At higher deasities and lower beam energles, the neutrala are primartly backurd peaked which causes more difficult design problems. This gource of high heat fluxes doed not oceur 1 n reactor-like configurations.

\section{II.2.2.3 End Tank/Direct Converter}

The end cell of a tandem ufrror is used for direct conversion and particle removal. Present designs of advanced mirror systems auch as MARs $(7)$ have four components used for heat removal in the end cell. These are the tnner and outer collector plates and the 1 nner halo (scraper) and outer halo (vented plate). These are depicted in Fig. II-16. The collector is segmented because different potentials are applied. The halo scraper is analogous to a tokamak pumped limiter. Particles gcatter off the scraper back into the halo plasma. Once retontzed they pass through the vented place and are pumped by the vacuum system. Thus, the scraper is subject to high heat fluxes and erosion rates. Present designs use a thick beryllium coating to provide sputter lifetime. This is deptcted in Fig. II-17 together with results of an analysis that shows how the 12-year sputter lifetime for MARS was determined. The heat flux on the outer halo is belleved to be below that constdered as a high heat flux component (100 $\left.\mathrm{W} / \mathrm{cm}^{2}\right)$; however, these $\epsilon$ stimates could be revised upward.

The distinction between FPD ${ }^{(B)}$ and MARs end cell designs is the desire for high quality heat in MARS which led to a coolent outlet temperature of $320^{\circ} \mathrm{C}$ and euffictently high pressure ( $\left.-3000 \mathrm{psi}\right)$ to auppress botling. The MARS structure 1a TZM, the only material that satisfies all constralnts. FPD 


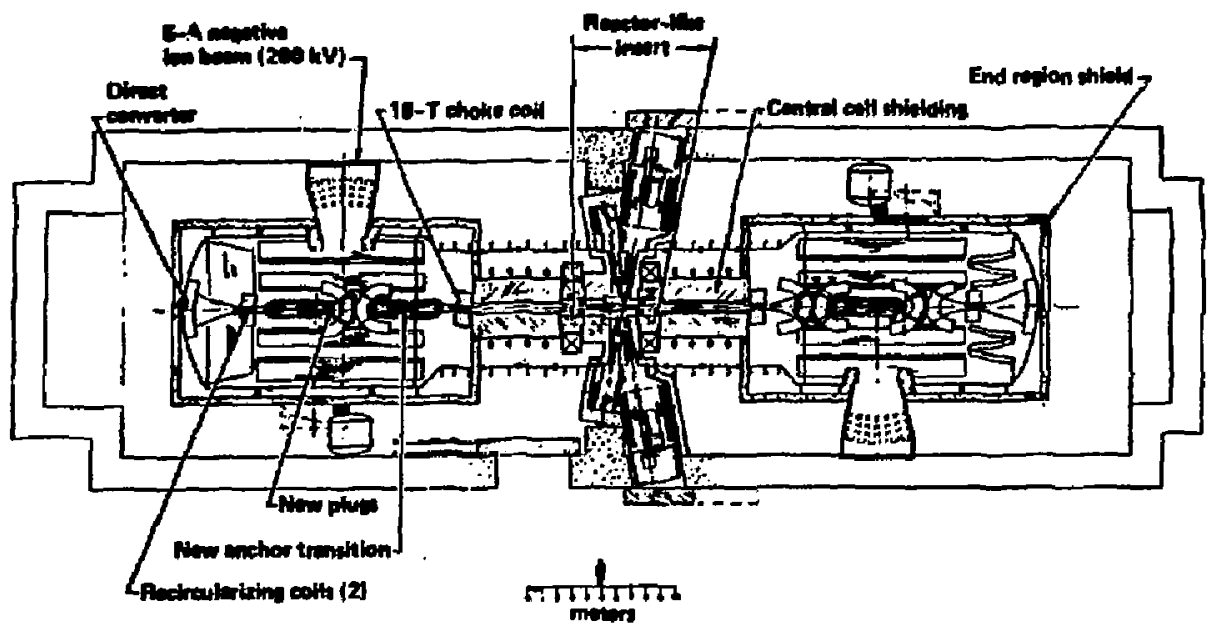

Fig. II-12, MFIF-U: Beaw and reactor layout.

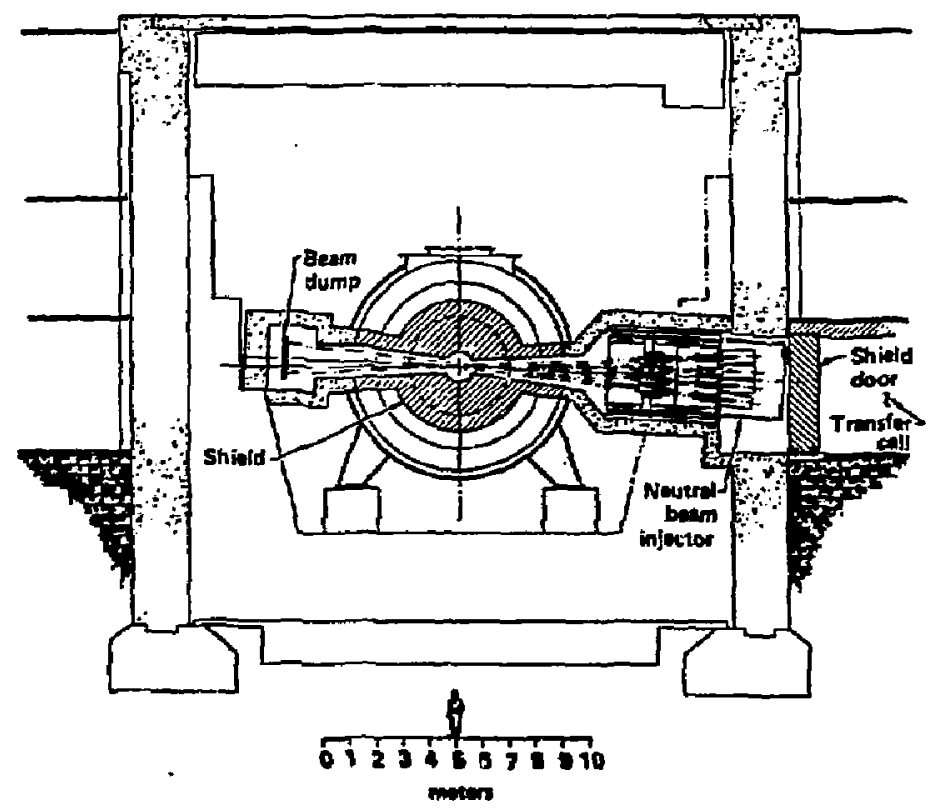

F18. II-13. ExtcrnaI bean dump configuration. 


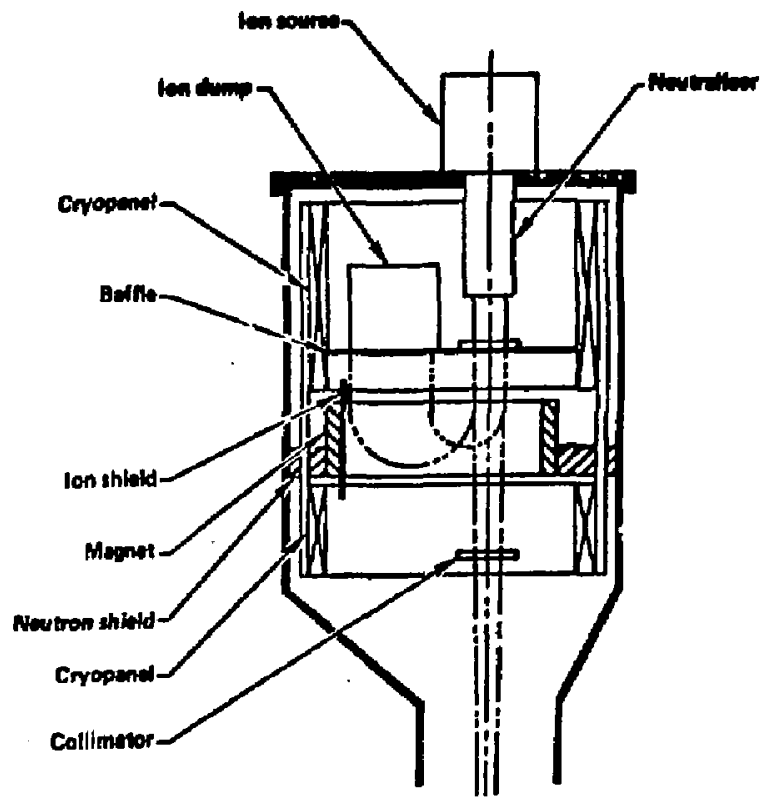

F1g. II-14. Internal beam dump configuretion.

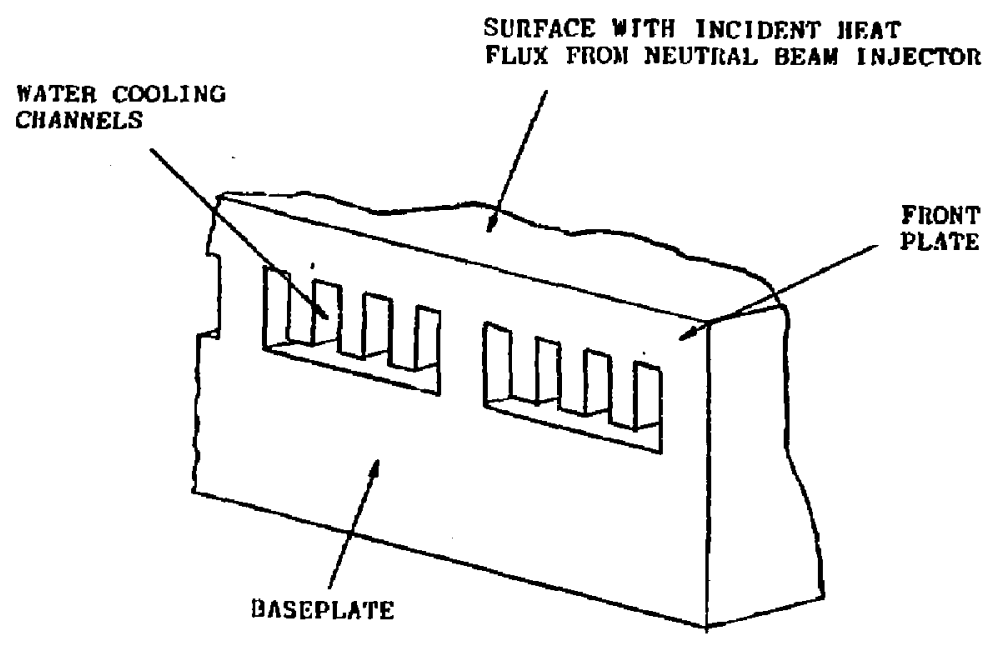

F1g. II-15. Typical beam dump dealga. 


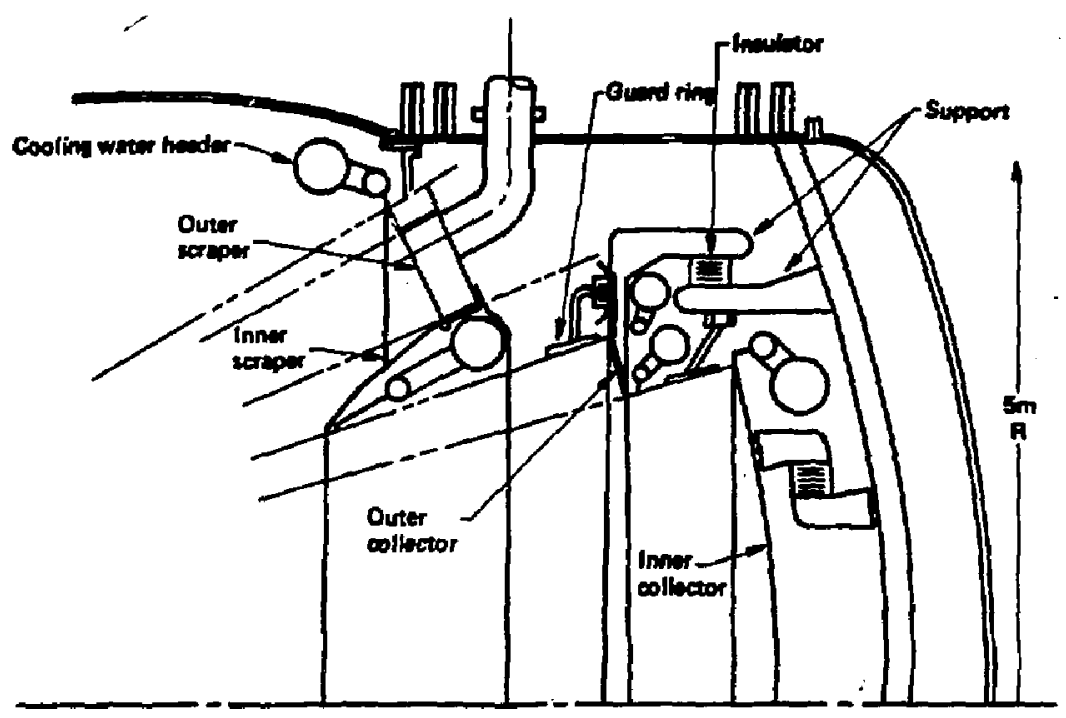

na)-2 (2)-421pp

F1g. II-16. Fad cell conf Lguration.

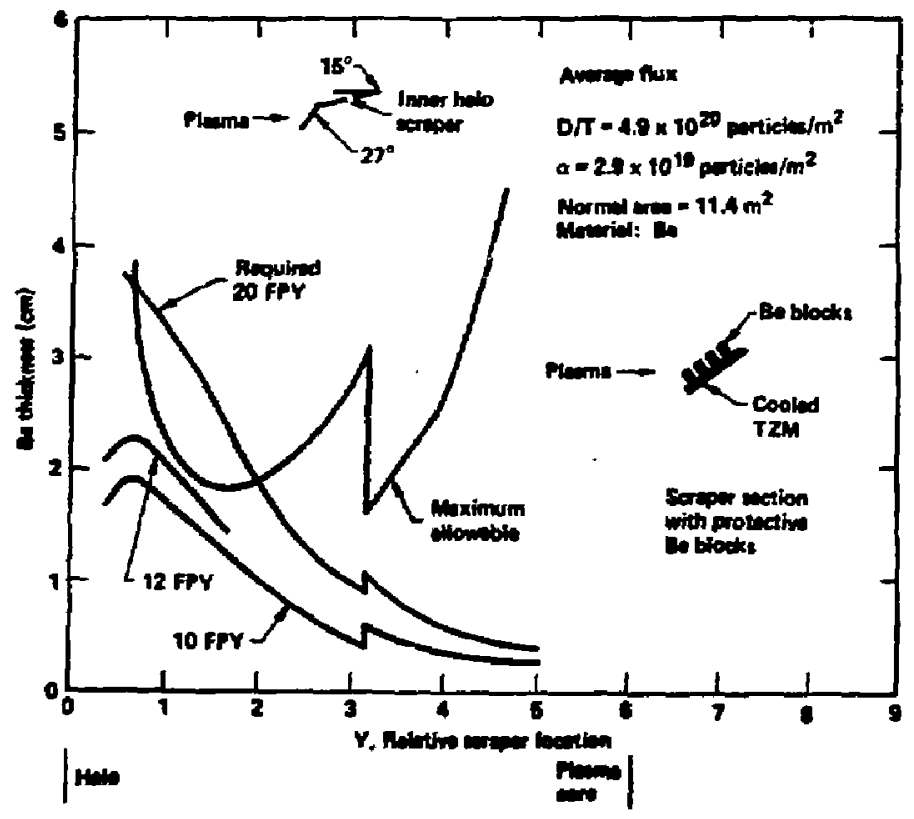

appib1)

F28. II-17. Inner halo configuration and analyola. 
operation would be at much lower temperatures and pressures. Copper alloys, stee1s, nickel alloys and vanadium would all be sultable.

The end cell components are subjected to a mixed environment of $D, T$, He and electrons. The most severe environments occur on the 1.ner collector and halo scraper. The particle currents and energies for the inner collector are given In Table II-1 and those for the Inner halo in Table II-2.

\section{II.2.2.4 ICRH Antennas}

Mirror reactors have ICRH heating in the end cell magnetic anchor to provide the high beta required for stability. Heat flux levels have not been defined but are expected to be comparable to those of a tokamak.

\section{II.2.3 Alternative Fusion Concepts}

The development of magnetic fusion energy is being puraued via two mainline programs, the tokamak and the tandem mirror. At a considerably lower level of effort, a number of less developed approaches are being pursued as alternative fusion concepts (AFCs). These approaches way eventually lead to a simpler, less expensive, or more desirable method of producting fusion energy.

The great varlety of AFC types, and their associated problems, will be discussed only briefly here through use of some of the more prominent concepts. Reference 9 contains a detalled discussion of AFCs and HHFC requírements.

A realistic groupling of the mogt promlnent AFCs follows:

- ELMO or Nagoya Bumpy Torus (EBT/NBT)

- Stellarator/Torsatron/Hellotron (S/T/H)

- Reversed Fleld PInches (RFP), OHTE, High Fleld Tokamak

- Compact Torolds (CTs) [Fleld-Reversed Conflgurations (FRCs) and Spheromaks]

The last three concepts (and others, see Ref. 9) have both a "conventiona1" or low power density (LPD) design point and a "compact" or high power density (HPD) design point. These "compact" systems are characterized by a fusion power core (FPC) of reduced size/mass with system power densities approaching that of a light water fisston reactor $\left(\sim 19.8 \mathrm{MWt} / \mathrm{m}^{3}\right)$. 
Table II-1. Inner Collector Pluxes.

\begin{tabular}{ccc}
\hline Particle & $\begin{array}{c}\text { Current } \\
\text { (A) }\end{array}$ & $\begin{array}{c}\text { Energy } \\
(\mathrm{keV})\end{array}$ \\
\hline$\alpha$ & 20.6 & 3862 \\
$\alpha$ & 50.6 & 942 \\
$D$ & 9.6 & 800 \\
$\mathrm{D} / \mathrm{T}$ & 73.8 & 353 \\
$\mathrm{E}$ & 1754 & 23.7 \\
\hline
\end{tabular}

Table II-2. Halo Scraper Fluxes.

\begin{tabular}{ccr}
\hline Fartic1e & $\begin{array}{c}\text { Current } \\
\text { (A) }\end{array}$ & $\begin{array}{c}\text { Energy } \\
\text { (keV) }\end{array}$ \\
\hline$\alpha$ & 1.4 & 3500 \\
$\alpha$ & 3.4 & 600 \\
$\alpha$ & 208 & 50 \\
$D / T$ & 1790 & 46 \\
$D / T$ & 4.9 & 107 \\
$e$ & 116 & 74 \\
\hline
\end{tabular}

II-17 
Many of the HHF problems are the same for the AFCs and the mainline approaches, especially for systems of equivalent system power densities. Therefore, the HHF requirements of the AFCs will be discussed relative to the requirenents of similar mainline and/or HPD components. In general, the HPD concepty operate under more stressed conditions due to the higher levels of neutron, radiation, heat, and particle fluxes. The high heat laads require that a substantial fraction of the first wall serves as the 11 miter or be covered by limfter components. This dual role, limfter and first wall, may fopose additional resirictions on the designs.

The problems assoclated with HHFC are neat term lsgues for some AFCs. Current experimental devices (CTX, 2T-40M, HBTX-1A, and OHTE) operate near to the conventional reactor conditions in terng of plasma beta and heat flux for pulse durations of $<25$ ms. The problems assoctated with equilibrium, impurity control, and thermal etresses will have to be solved before optimum rachine parameters can be obtalned for the devices presently in operation.

\section{II.2.3.1 First Wa11}

Reactor concepts based of the FRC utilize plasmoids which translate through a burn region which has a resistive flrst wall and a flux conserving she11. The pulsed nature of this scheme results in a potential thermal fatigue problem for the first wall.

Although some spheromak reactor scenartos involve translating the oblate configuration, translating these plasmolds through a long-linear burn chamber will not maintain an equilibrium. (10) These equflibrium constraints lead to stationary spheromak reactors surrounded by a loosely fitted conducting shell. The HHF characteristics of this first wall will be glallar to those of the RFP.

Por the RFP, a careful assessment of the critical features and parameters of the conducting shell is necessary. If the flrst wall must also be the conducting shell, additfonal complications may be imposed on the destgn. Wall armor and or 1 mafter components must be designed which are compatible with the plasta equilibrium and stablifty. The HPD systems will have to utflize large surface areas of graphice (coated or uncoated) or copper first walls due to the higher heat fluxes. If HHF coatings are used, a wethod for in situ replacement of the coating will have to te developed for future devices. 
The wall loadinge for the EBT and $5 / T / H$ are the oame or lesa than for the tokamak. The three-dimenstonal helical character of the S/T/H presents added engtneering difficulties for the first wall, and the continuous use of larist amounts of ECRH may necessitate the developnent of first-wall components with hIgh electrical conductivity for EBT.

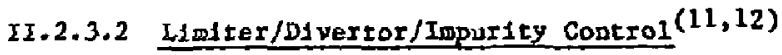

Very little experimental or theoretical work has been done $v_{\text {sth }}$ 1Imiters or divertors in the AfCs. As the duration of the experiments ge. longer, the 1ssues of plasma materials interactions (PMI) and 1mpurity contril will become much more Important. These tssues way be responsible for the present difficulcies in some present devices operating with high thert al wall loadings $\left(\geq 1 \mathrm{MW} / \mathrm{Im}^{2}\right)$ such as $\mathrm{HBTX}-1 \mathrm{~A}, \mathrm{OHTR}, \mathrm{CTX}$, and $2 \mathrm{~T}-40 \mathrm{M}$.

Current RFP experiments have begun to use limiters in an effort to protect the vacuum liner from the high heat loads. This work ts in its infancy and extensive theoreffcal as well as experimental work will have to be actively pursued if the present generation of devices are to operate routinely at their deslgn current levels. The limiter systems will have to be designed so that they do aot introduce plasma equilibrlum or stabllity problems, and they will have to tolerate the $h\left(g h\right.$ heat loads $\left(\geq 100 \mathrm{MW} / \mathrm{m}^{2}\right.$ ) for short pulses ( $\leq 25 \mathrm{~ms}$ ) without 1ntroducing 1mpurities Into the plasma syatem. Injection of gas Into the boundary layer will be ut1liaed In ZT-40M to study the effect on the plasma parameters in the edge plasma reglon. Either pump 11miters or divertors will have to be developed for use on the longer pulse devices (ZT-H and $\mathrm{RFX}$ ).

IPD operation will place even more stringent requirements on the limiter/ dfvertor systems, A larger fraction of the wall will be ipvolved in the interaction and very tight control of the plasma equilibrfum and edge plasma parameters 111 be necessary. Even though the peak stresses may be higher for HPD operation, the solutions should logically result from extenstons of technologies learned at the lower strese levels. Both pumped-limiter and magnetic divertor particle control schemes are being constdered; however, more experimental and theoretical work has to be done before thege designs can bè finalized. 
The RFP and OHTE UPD options require extenstons of technology by factors of $\sim 5$ from conditions in the LPD optlons; however, the RIggatron requires'extenglons of approxiuately another factor of 5 .

The three-dimensional helical character of the $S / T / H$ presents added difficulties for the englneering of divertors or Iimiters which edapt to this helical symetry. If a UPD option is Identified, the problemg would be siat..... lar to those for the OHTE device discussed above; otherwise, the problems should be simllar to those of the tokamak.

The limiter/lmpurfty contro1 issues and solutions for the EBT concept are very stmilar to those of the mainline programs.

Both the spheromak and the FRC have natural magnetic divertors. The PMI and HHF 1ssues will be the same as the mainline program; HPD options will have correspondingly wore heat flux, however. The spheromak approach(13) ut1lizing electrodes for injection of magnetic helicity will have to develop or Identify the technology necessary to prevent the infection of impurities from the electrodes.

\section{$I I .2 .3 .3$ Auxiliary Components (RF, $\mathrm{NBI}$, etc.)}

The need for the development of NBI and RF components for plasma heating and current drive is basically the same for some of the AFCs [S/T/H, EBT/NBT, CT (some concepts)] as for the matnline programs. Current drive for the RFP (ZT-H) via F- $\theta$ pumpling will use low frequency $(\sim 1 \mathrm{kHz})$ components which should not require the development of new technology. A careful assessment of the crltical features and parameters of the conducting shell for RFPa (ZT H) will be of major Importance with respect to design of the other PMI and HHF systems.

\section{II.3 Sygteme Integration Considerations}

\section{II.3.1 Safety}

In principle, nearly all safety concerns relevant for the first wall and blanket are relevant for high heat fIux components. The severicy of any potential safety problem and the 1mportance of the associated safety ccasideratfons aze strong functions of material chotee, component destgn, and location 
In the reactor. Any analysis of safety concerns involving high heat flux componente wust necessarily coasider the comfoume in the larger reactor context, 1.e., how the component influences the overail reactor performance.

For the purpose of this brief overview of posstble safety concerns, safety considerations can be divided into two areas, (a) radloactivity and chemical toxicity contral and (b) Interaction with the surrounding reactor.

\section{II.3.1.1 Radioactivity and Chemical Toxiclty Concrol}

Several considerations related to radloactivity and chemical toxicity are apparent: the induced radioactivity in the component, cheafcal toxicity of component materials, the vulnerability and potentfal for release of this activicy/toxiclty, permeation of tritlum through component structure into the coolant, and the tritium inventory in the component.

Material activation (discussed fa Sec. LI.3.2) is actually several 1ssues, e.g., occupational maintenance exposure, accidental release, af terheat generation ant waste disposal/material recycle. Materfal preferences are a function of which of these lssues are more Important. For example, No is la disfavoz due to its waste disposal problem of high long-lived actlvity; however, at short times fts activity is lower so that accidental exposure per unit material is less dangerous than several other elements, e.g., 1rradiated N1.

Nonetheless, some general guidance for structural material choice is possible. The most preferred are $\mathrm{Si}$ and $\mathrm{C}$. The second general class is $\mathrm{Mg}, \mathrm{AI}$, and $v$. The chird general clase can be subdivided, with (a) Ti relatively more attractive, (b) $\mathrm{Zr}$ and $\mathrm{Cr}$ less etractive, (c) $\mathrm{Cu}, \mathrm{Pe}$, and $\mathrm{W}$ attll less attractive, and (d) Mn. The final class, which should be avolded, is composed of $\mathrm{Co}, \mathrm{N} 1, \mathrm{Mo}$, and $\mathrm{Nb}$. Mo and $\mathrm{Nb}$ are the worst cholces from the waste dLBposal standpolnt. In addfton, Mo oxidation products are quite volatile and form at a high rate. $N 1$ and to are the worst structural choices from the accidental exposure from a stoichlometric 316 SS/PCA release would come from Co lsotopes induced in the NI constituent in austentif steel. The accual hazard frow an alloy depends on tta compostition, including impurites. For "low activation" materials like SIC and Al alloys, the tmpurity concentration becomes quite significant. 
Among possible coolants, $\mathrm{Na}$ and $\mathrm{K}$ should be avolded due to their activation. Activated corrosion products could be a concern if the metal/coolant Interface temperature was high enough to cause algnificant corrosion accivation product formation and release.

In terms of chemfial toxicity, the key concern is Be. It is not yet possible to definitively compare Be toxicity with activiation hazards. Chemical toxic1ty does not decay; however, possible accidental public hazards due to Be per unit amount released are less then many of the metals mentloned above.

One aspect of the vulnerability of the high heat flux component radioacLivity ts the component's response to inadequate cooling. By definition, the heat load on such components w1ll be quite high. Therefore, the time allowed for corrective action following a loss of coolant or flow blockage/stoppage before damage can occur will tend to be short. Component design and material cholce should consider how the component can be made more tolerant to such faults.

In the area of trittum permeation, the component structure's permeability 1s key. In this regard, $W$ is most preferred. Then come, In order, Mo, Cu and steels. $V$ and $\mathrm{Nb}$ are least desired. If a two-metal structure is used, ir is far more Important that the low permeab" 1 ty material be on the coolant side so that implantation on the plasma side cannot bypass the intended critium barrier.

The relative Importance of the tritium permeation problem is dependent on the difficulty of removing tritfum from the high heat flux component. Water coolant is probably the worst cholce since th ts quite expensive to remove HTo from water. Use of 1 thilum or $17 \mathrm{Li}-83 \mathrm{~Pb}$ as coolants would minimize the issue of the permeablifty of the structure-more tritium would likely be produced in the lithium than encers from the plasma. Tritium inventory in the component structure shauld also be minimized.

\section{II.3.1.2 Interaction with Surrounding Reactor Component:}

HHF component design should strive to minfmize the possibility of serfous interaction. During off-normal operation or accidente, and to mitigate any consequences of Interaction. 
Plagina disruptions, or olmflar events, may cause their most serlous damage to high heat flux componente, e.g., a limiter. The component should be designed to whithand these translents, both to decrease direct damage to the component and to ellminate indirect damage to other reactor componente from propagating fallures.

Leakage of component coolant into the vacuum chamber could also lead to overpressure of the chamber or oxidation of 1cs surfaces. For exaraple, release of a substantial amount of water from a limiter into the chamber could rupture the vacuum barrier and damage vacuum pumps. Exposure of a reactive metal, like $v$, at high temperature to steam from a water-cooled limiter fallure could lead to severe wall damage.

similarly, a double fallure of the high heat flux component and blanket would allow component and blanket flutds to latersct. A afngle initiator event, e.g., disruptions or seismlc events, could, in some cases, cause such a double faflure. The consequences of such reactions would be severe enough in the case of a water-cooled HuFC and a liquid lithium blanket that such combinations may be ruled out for use in power reactorg, particularly if $V$ alloy is used as the FW/: structure. The reaction between $1711-83 \mathrm{~Pb}$ and water is less eaergetic, and the use of water-cooled HHF components with such blankets maj be acceptably safe. Water coolant is acceptable for use in HHFC's with all solld breeder blankets.

\section{3.2 Act1vation Products}

Accurate evaluation of neutron-1nduce.1 component activation is cruclat in establishing shielding requirements, design concepts, malntenance procedures, and personnel access to experimental areas. The evaluation ts siso vital in reactors.

There are three areas that must be inysstigated fa terms of the fupact of component activation: (1) radioactive waste management; (2) reactor malntenance; and (3) reactor safety characteristics. The primary incentives for constderacion of reactor bafety tn the ease of a severe accident, and of long term waste management, relate to environmental impacts. Incentives influencIng naintenance considerations, In particular "hands-on" or "contact" mainterance considerations relate primarliy to economics. 
Table II-3 summarizes sone of the activation analyses published to date, usling two radloactivity measures, $\mathrm{Cl} / \mathrm{cc}$ and rem/h. All the analyses have been done for values of integral neutron wall load, $I_{W}$, typical of power zeactora. Materials for high heat flux : smponents are grouped lato three categorfes: (1) coating/surface materfals; (2) heat sink materlals; and (3) otructural materfals mostly for the first-wall application. The analyses have been carried out without including typical impurities/trace elements except for a few structural materials (e.g-, A1-6063, Ti6A14V, V15Cr5Ti, and PCA) and SiC, where these are more 1mportant.

Sevel.t: 1mportant observations can be made from the results shown tn the table. Firgt, the high-purtty coating/surface materials show do not seem to pose any long-term radwaste problems. Particularly, the low- $Z$ coating/surface matertals exhibic a very rapid decay of activation shortly after shutdown. A careful maintenance scenario tuat be established for use of SiC as a high heat flux material because of the formation of ${ }^{31} \mathrm{SI}(2.6-\mathrm{h}, 1.27-\mathrm{MeV}$ gamma eni; sion) tiy th.e ${ }^{30} S \pm(n, \gamma)$ reaction. All of the long-term activation associated with the constituent elements are soft-energy beta emftcers such as ${ }^{14} \mathrm{C}$ and ${ }^{10}$ Be. For near-term machines the plateau values of the long-term activation w11l be substantially lower than those shown, for near-term machines because the production rate is approximately proportional to the Integral wall load. Second, copper used as a heat sink macerial will be highly activated and may require careful consideration for the post-irradiation handling. Shortly after shutdown, the copper activation is dominated by the 1.35-MeV gamma emission of ${ }^{64} \mathrm{Cu}$ which appears ta pose a difficult maintenance problem. Even in a near-term machine, an apprectable amount of ${ }^{64} \mathrm{Cu}$ production is expected because of the short half 11 fe ( 12.7 years) af ${ }^{64} \mathrm{Cu}$. High purity vanadium a1loys seen to be more acceptable for use as heat sink materlals from the activacion standpolnt, but strict control of the impurities/trace elements is cructal.

Finally, all of the structural materials shown exhibit quite high radioactivity in ci/cc as well as in rem/h. In addition to important waste disposal considerations, the activation of these structural materials w111 become very Important for reactor accessiblity or contact maintenance considerations, as Indicated by theit very high bfological dose rates shortly after shutdown. Unfortunately, it is expected that quite high dose rates are likely to occur 
Tabie II-3. Comparioon of Activation for Varioug HHfC Materiels

\begin{tabular}{cc}
\hline Radioactivity (Ci/cc) & Dose (Rem/hr) \\
Tine After Shutdom & Tine After Shutdown
\end{tabular}

Major Contributor

Material Rof. 0 I Yr $100 Y_{r}$ D 1 d $100 r_{r}$ to Long-lem Activatlon

(A) CQATING/SLLFACE MATERIALS

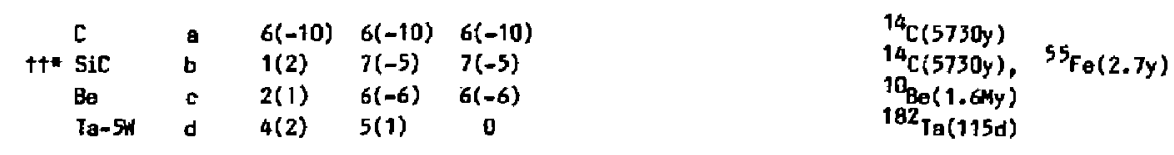

(B) HEAT SINK MATERIALS

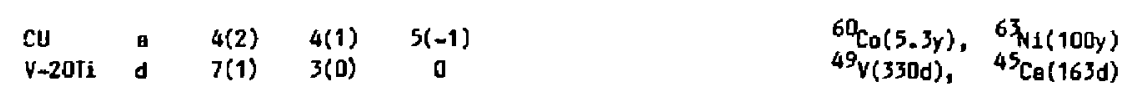

(C) STRLCTLRAL MATERIALS

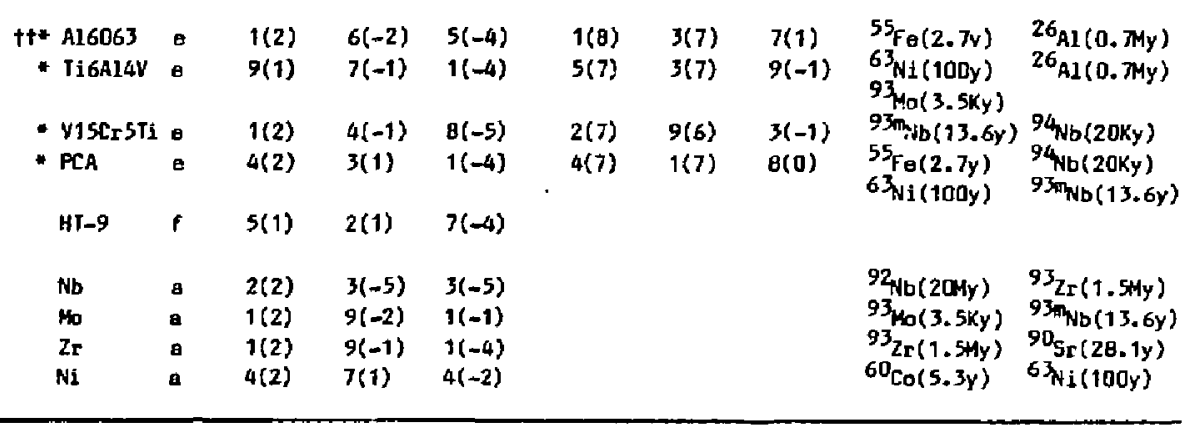

Ref. (a) "Panel Report on Low Activation Materlale for Fusion Application," Draft, Appendix II (1982); $I_{w}=3 \mathrm{HW} / \mathrm{m}^{2}$.

Ref. (b) "Background Information and Technical Basis for Assessment of Environuental Implication of Megnatic Fusion Energy," Draft, U.S. DOE (1983); $I_{W}=18 \mathrm{MW}-\mathrm{yr} / \mathrm{m}^{2}$.

Ref. (c) 3. Jung, Nucl. Technology/fusion, $4144(1983)_{j} I_{W}=9 \mathrm{MW}-\mathrm{yr} / \mathrm{m}^{2}$ (Cat-D).

Ref. (d) C. Baker, WL/FPP-BO-2 (1980); $I_{W}=: B \mathrm{HH}-\mathrm{yr} / \mathrm{m}^{2}$.

Ref. (e) J. J. Jung, Nuel. Technology/fusion, 4 $566(1983) ; I_{W}=18 \mathrm{MW}-\mathrm{rc} / \mathrm{m}^{2}$.

Aof. (f) J. Jung, unpublighed work for STARFIAE (1979); $I_{W}=5$ MH-year $/ a^{2}$.

$t$ : Read as $6 \times 10^{-10} ; t+$ (*) denotes inpurities included. 
even In near-term machines due to a varfety of short-1ived gamms enfters formed in the constituent elements $\mathrm{Al}, \mathrm{TI}, \mathrm{V}$ and $\mathrm{Fe}$.

The long-term activetion In V15Cr5TI is generated only by its impurities, most importantly by nioblum and molybdenum. These two elements predominantly contribute to the high radoactivity in ci/ce as well as to the high dose rate in rem/h via the generation of $93 \mathrm{Nb}, 93_{\mathrm{Mo}}$, and $94 \mathrm{Nb}$. It 18 therefore very degirable from the standpoint of radwage management to use vanadium-base alloys with extremely low levels of $\mathrm{Nb}$ and Mo Impurities.

\section{II.3.3 Economics}

\section{II.3.3.1 Relfability}

Highly reliable HHF components are needed in near-term fuston devices in order to maximize the operating time avallable for experiments. In power reactors high levels of reliabllity in HHFC are cruclal, to keep unscheduled maintenance for changeouts of falled components to a minimum so as to maximize plant avaliabllity.

An example of the rellabilicy levels considered necessary for typical HHF components is shown in Table II-4. For first wall coolant panels and pumped limiters in tokamaks, the estimated reliability-as expressed in mean time between fallures, MTBF--is given for the two systems (each composed of $\underline{n}$ untts as indicated). These are reliability levels considered necessary to be achleved in each device in order to reach the designated overall avallabllity goal for that device. (Similar numbers for MRs and alternate concepts are not avallable.)

It should be noted that, in order to assure with a high probability that the desired MTBF for any HHF component will actually be achieved when operatIng In the device, the total test time that has to be accumulated beforehand on tear-1dentical components is higher than the desired MTBF by several mult1ples. (1) For example, If teating in ETR is used to assure with $95 \%$ confidence that the MTBF of the same limiter in DEMO will be 8000 hours, then a total of at least 28,000 hours of 11miter operation in ETR (all lifuter units combined) would be necessary. Such relationships of accumulated testing time to desired reliability levela are very Imparcant when planning development programs for HHF or any other critical component for fuoton devices. 
Table II-4, Estimated Requirements for Reliability

of HHF Components for Tokanaks

\begin{tabular}{|c|c|c|c|}
\hline $\begin{array}{l}\text { Component } \\
\text { (No. of Units) }\end{array}$ & Wachtne & $\begin{array}{c}\text { MTBF (Mean T1me } \\
\text { Between Faslures) }\end{array}$ & $\begin{array}{l}\text { HTTR (Mean Time } \\
\text { to Replace) } \\
\end{array}$ \\
\hline \multirow{3}{*}{$\begin{array}{l}\text { First Hall } \\
\text { Panels } \\
\text { (24) }\end{array}$} & $\operatorname{ETR}^{a}$ & 2,200 hrs & $420 \mathrm{hr}$ \\
\hline & DEMO $^{\mathrm{a}}$ & 4,400 & 210 \\
\hline & STARFIRE & $\sim 9,000$ & $\sim 288$ \\
\hline \multirow{3}{*}{$\begin{array}{l}\text { Pumped Limiter } \\
\text { (12) }\end{array}$} & $F T R^{a}$ & 4,000 & 336 \\
\hline & DEMO $^{a}$ & 8,000 & 168 \\
\hline & STARFIRE & $\sim 72,000$ & $\sim 288$ \\
\hline
\end{tabular}

\section{II.3.3.2 U Use of Power from HHF Components}

The efficlency with which the power removed from HHFC can be used in the power generation system of a fusion reactor can strongly affect the cost of electricity (COE) generated by the plant. It 1s important to design the HEFC, if posstble, to permit the use of coolanto with high outlet temperatures so that power conversion efficlency can be maximized. From the standpoint of power production, the choice of AHFC coolant and Its operating parameters will be Influenced by:

- Power conversion system cost and complextcy

- Pocential for tritium contanination of/loss into ateam generator secondary side (or turblne, etc.)

o Thertal efficlency obtalnable with various system configurations

In recent tokamak reactor atudies, $(2,3)$ water coolant at relatively low pressures and temperatures has been selected for both the FW/B and the Impurity control device. The MARS study (7) uged high-preasure, high-temperature water coolant from the TIR'B halo scraper and direct convertor for feedwater 
heating, In conjunction with the 17LI-83Pb liquid metal breeder/coolant used for the $\mathrm{FW} / \mathrm{B}$.

The dea1gn lifetise or rellability of the HiFC 1s likely to be reduced as coolant outlet temperatures are 1ncreaged. For example, surface erosion I1fet1mes for pumped 11miters are a function of allowable erosion thickness, which nay decrease with lncreasing coolant outlet tenperature if thickness is linited by the difference between maximum allowable surface temperature and coolant/structure interface temperature. However, reduced life rad rellability must be traded of $f$ againist econoric penaltieg. An extreme case would be to reject all power absorbed by the HHFC as waste heat. As examples, for Starfire, (3) elfminating the $200 \mathrm{WWth}$ from the limfter $\left(145^{\circ} \mathrm{C}\right.$ coolant outlet temperature) which was used for feedwater heating would decrease net power output by $\sim 5 \%$. For MARS, ${ }^{(14)}$ rejecting the $\sim 280$ MWth from the halo scrapers and direct converters $\left(320^{\circ} \mathrm{C}\right.$ coolant outlet temperature) would decrease net power output by $\sim 8 \%$. COE would rise approximately in inverse proportion to the power reduction in both cases.

\section{II.3.3.3 Design Lifetime}

The design lifetime of an HHF component, In terms of impact on reactor avallability and economics, can be defined as the time elapsed between its installation and its removal as part of scheduled malntenance to prevent it from exceeding allowable limits based on some parameter (e.g., nigimum ductilicy 11mit based on total fluence accumulated). :

The impact of shorter design lifetimes on plant economics for power reactors comeg principally through (1) Increased costs for spares, and (2) decreased avallability in the event that total time required for component changeout exceeds the downtime allotment for other scheduled majntenance. For near-term experimental devices, the Impact of reduced avallability $1 \mathrm{~s}$ on the testing schedule rather than on economics.

As with the dectsions on the utilization of power from HuFC, the determination of design lifetime for these components mast also involve tradeoffa to optinfize reactor economics. As an example of the importance of HHFC design 11fetime, the Starfire (3) pumped 1imiter design lifetime was 6 years (based on ourface egogion) and the limiter was assumed to be changed out with the FW/B sectors on a rotating schedule during the annual shutdown for maintenance. 
Thus 110iter l1fe had no particular effect on availabllity. However, if erosion rates were much higher so that 211 liniters had to be replaced every $\mathrm{Bix}$ months, an additional scheduled shutdown of at least 30 days would be needed for this operation. Assuning no other changes to the maintenance scenarto, plant avallabllty would decrease fran $75 \%$ to less than 67\%, and $\cos$ would Increase by $\sim 12 \%$.

For those compact EPD systems that can operate efflclent1y at high neutron firse wall logding $\left(10-20 \mathrm{~mW} / \mathrm{m}^{2}\right)$ with exo-blanket resistive colls, fusion power core (FPC) power densitieg in the range of $10-15 \mathrm{mWt} / \mathrm{m}^{3}$ are posstble. For a radiation life fluence of $15 \mathrm{MW}-\mathrm{yr} / \mathrm{m}^{2}$ the $20 \mathrm{MW} / \mathrm{m}^{2} \mathrm{CRFPR}$ aystem would operate for 0.75 full-power years (FPY), or approximately one chronological year ( 757 plant factor) before changeout of the 45-tonne first wall and blanket system. If the $20 \mathrm{HW} / \mathrm{m}^{2}$ HPD design can be technically achleved, a few single-plece "batch" malntenance schemes may be posstble, wherefn a completely assembled and pre-tested first-wall/blanket/ohleld/torofdal-field-coll unt would be installed in the reactor ha11 after off-site rabrication and qualfty assurance. The potential for a reduced mean-time-to-repalr can be traded off with the possibly decreased mean-time-to-failure. High plant availability and reduced costs may thus be possible, which makes the higher wall loading designs attractive, since cost of electricity is a weakly diminishing function of wall loads.ng above $\sim 10 \mathrm{mw} / \mathrm{m}^{2}$.

\section{II.3.3.4 Malatalnabfilty}

The maintenance of HHFC in present experimental devices to characterized by fully manual operations for removal and replacement, or in-situ repair when feastble. Full access to workers is possible because trittum is absent, wateIlal activation levels are very Iow, and the bullding atmosphere is air. The malntenance of HHPC for all future devices which burn D-T fuel wll have to be by fully remote methods. In-altu repalra will probably be reatrficted to recosting operations only. If activation levels permit workers to enter the reactor hall at all, the workers w1Il wear "bubble sults" because of tritium contamination of the bullding atmosphere, which would probably be a gas rather than air except for near-term deviceo.

As a result, for future devices there will be strong emphasis on making HHPC easily maintalnable, with changeouts accomplished remotely using simple 
operations and total downtime miniulzed. Coolant $f$ ine connections and vacuum boundary geals in particular will have to be easily broken and remade. Any refurbishment of the removed components (e.g., replacement of armor tileg) will have to be accomplished in hot cells after a new replasement component has been installed and device operation has resumed; most in-sicu refurblshment (with the device not operating) wauld simply take much too long to be elther economically feasible (for power reactors) or reasonable in terms of test schedule impact (for near-term devices), as indicated by Fig. II-18.

As the requirements and problems of HHPC have become better deflaed, reactor design studies have placed increasing emphasis on laproving the maintalnability of those components. An example is provided by pumped limiters for tokamaks. The limiter for Starfire(3) was integrated structurally with the FW/B sector, and was removed and replaced together with the sector (Fig. II-19a). For the later DEMO study, (2) the Ifmiter dealgn was nodffled so that the entire unit could be withdrawn from the blanket sector as a separate module (Fig. II-19b), without requiring sectcr removal. Estimated removal/ replacement time was cut from $\sim 12$ days, to $\sim 6$ days (unscheduled maintenance for a fatled component).

\section{II.3.3.5 Tritiun Breeding Effects}

The incorporation of relatively large HHF components, such as divertors or Ifmiters in tokamaks, into the reactor requires that the assoctated penetrations be accormodated by the tritium breeding blanker system. Such HHFC w111 reguire openings $1 \mathrm{n} 1$ f first wall having direct visibility to neutrons from the plasma.

The trittum breeding ratio (TBR) will be affected by (1) the changes due to the penetrations themselves ${ }^{(15)}$ (influenced by neutron spectrum variation, reduction in breeding zone volume, enhanced neutron Ioss), and by (2) the absorption or multiplication of neutrons by the materials in the HuFC. Radiation atreaming through penetrations enablea high energy neutrons to penetrate deeper Into the blanket, Insreasing the Li-7 reaction rate. Volume reductions In the breeding zone depend strongly on the type of penetration. The relative TBR reduction depends on the exact characteristics of the penetration. For typlcal neutral bean infectors the reduction can be $\sim 2 \%$. (16) The use of a 


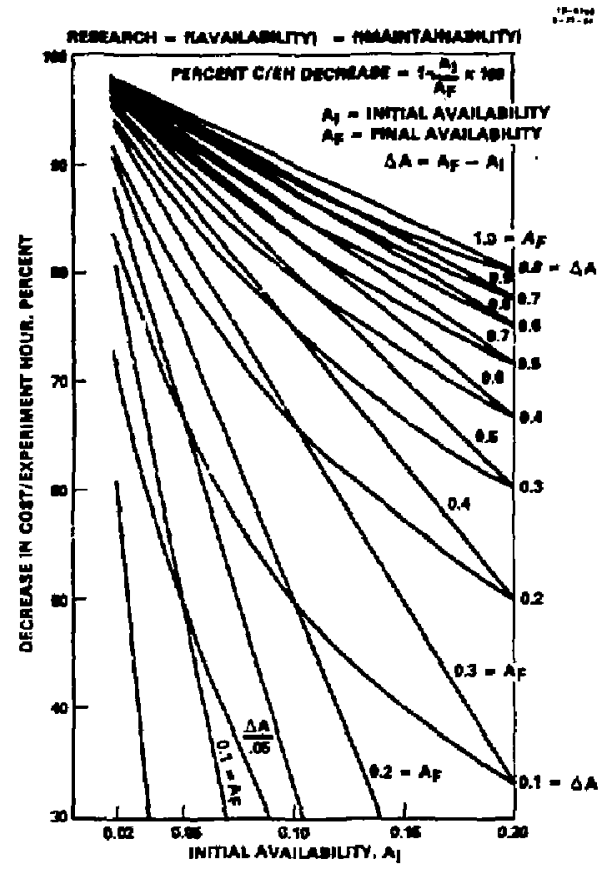

Fig. II-18. Impact of avallability to experimental fubion devices.

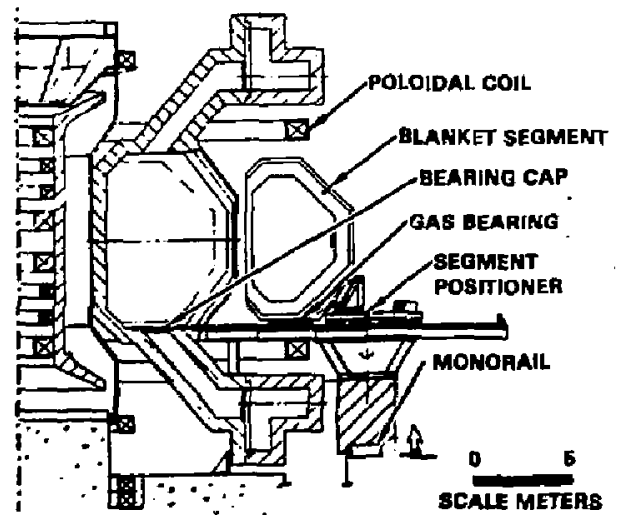

(a) STARFIRE - Limltor Romoved With Blankot Sector

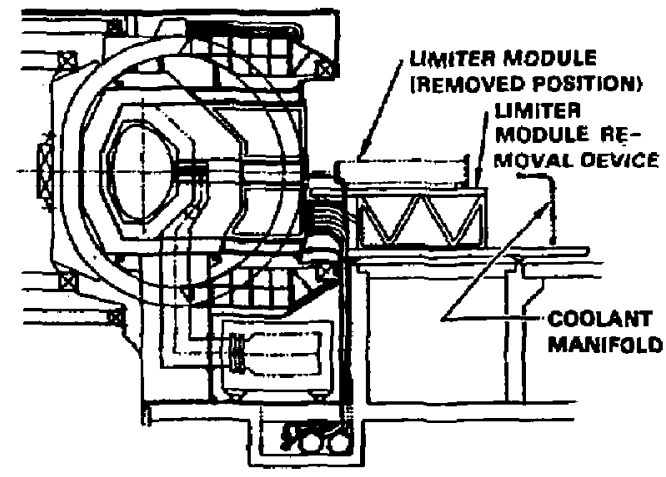

(b) DEMO - Limitor Module Separately Removabie

FIg. II-19. Comparison of IImfter maintenance approaches for Starfire and Deso. 
pumped $11 m i t e r$ can reduce TBR by $\sim 5 \%,(17)$ and a divertor systen can result in even greater reductions.

Recent analyoes(18) to determine the effects of IImiter location and coolant choice on TBRs for vardous blanket concepts indicate the effects of both can be fmportant, particularly for blankets concepts marginal in breeding. Table II-5 summartzes thise preliminary results. The effect of $\mathrm{H}_{2} \mathrm{O}$ in depressing TBR for a He-cooled $\mathrm{LI}_{2} \mathrm{O}$ blanket $\mathrm{Lo}_{\mathrm{o}}$ evident, and would have to be accounted for in selection of a 11miter coolant. Likewise, moving the lialter from the midplane to a bottom location appears to fuprove TBR in all three cases, but by differing degrees.

Table II-5. Effect of Limiter Location and Coolant Cholce on Tritium Breeding Rat1ob

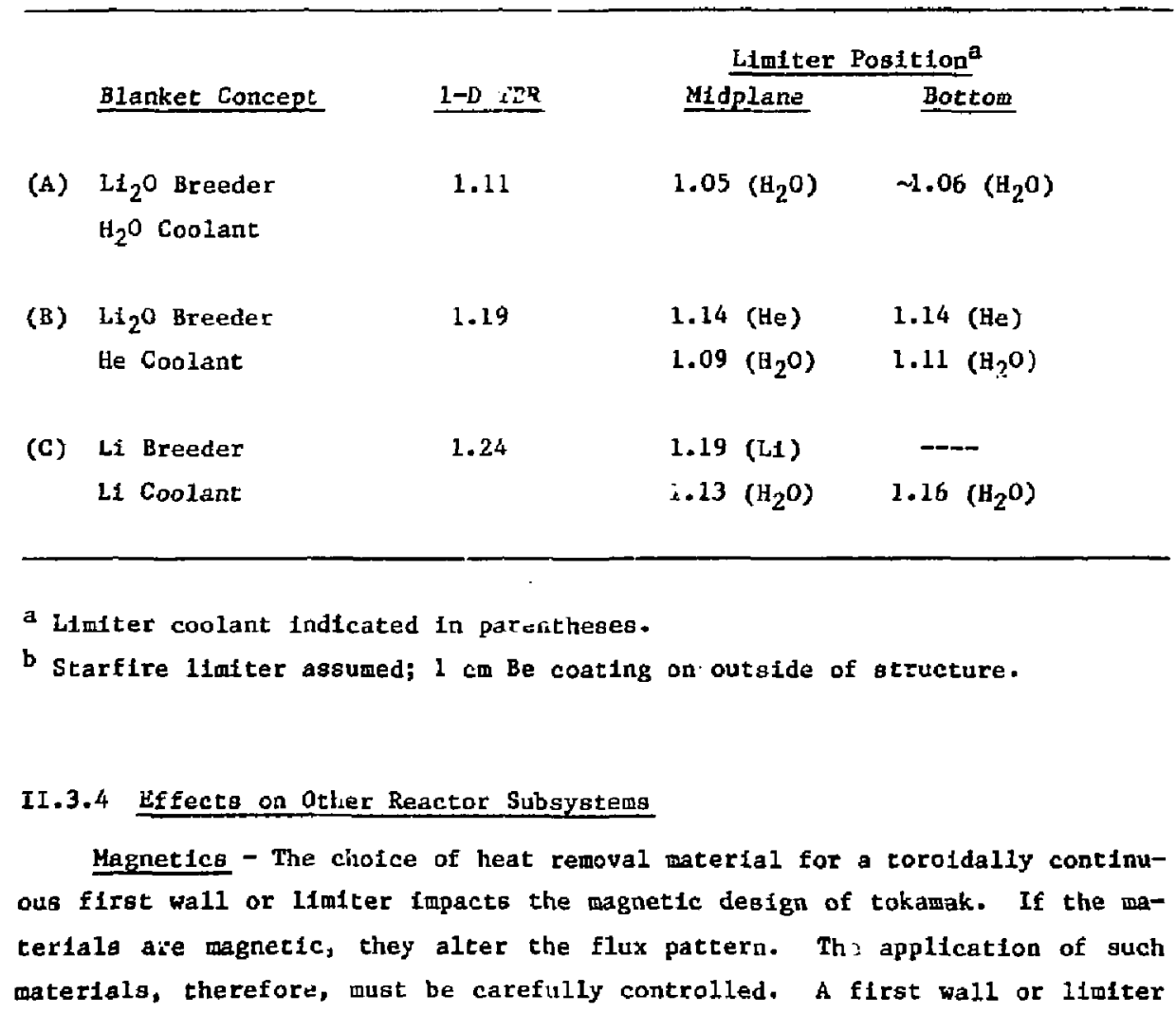


constructed of a highly conductive matertal, such os copper, provides a good toroldal eddy current path near the plasna. Thts feature absists in provtdiag plasma stability and prevents arc erosion during transient electromagnetic events, such as disruptions. On the other hand, the etartup and control coll powers and valtages are adversely affected by this highly conducting toroldal path. The FED-A design study (19), which Incorporates a highly conducting copper 1Imiter and first wall, demonstrated chat a gelf-conslotent and practcal design with respect :o plasma atability, startup, and control is feasible.

Plasma Interaction - All components exposed to the plasma are subject to erosion by sputtering, evaporation, etc. and constitute a potential source of 1mpurities to the plasma. Furthermore, recycling and permeation of plasma particles, Including tritium permeation through walls and into cooling channels, depends on the chosen materials. Consequently, the materials choice for plasma side components has to be compatible with plasma operation. The effects of plasma material interaction are discussed in detall in the Technical Assessment report of the PMI task group.

\section{II.4 Key Issues and R\&D Needs}

The four prloritized 1ssues and related RSD needs discussed below were developed based on the systens integration aspects of HHFG as discussed in the preceding sectlons. Two polnts should be mentioned. First, these 1ssues focus principally on the needs of the two malnifine reactor concepts, tokanak and tandem minor. Successful resolution of these 1ssues will also resolve similar issues for many of the low-power-density alternative concepts. The HHFC-related Issues for most of the high-power-density alternative concepts do not appear to be well enough deflned at this time to warrant large-scale R\&D expendicures. Second, the losues relate prinicpally to the needs of power reactors rather than near-term or present experimental devices, because the most pressing problems for such devices appear to be related to materials and thermal-hydraulics 1ssues rather than to systems integration.

\section{II.4.1 Lifetime of Impurity Control Devices}

For 11miters and divertor target plates in tokamaks, and for halo scrapers In TMR's, useful life appears to be limited principally by high erosion rates of the 10w-2 armor. Lifeclmes of less than 1-2 years will likely result 
In extensive dowat1mes for scheduled renoval and replacement, reauiting in reduced avallabllity which raises the cost of electriclty.

Operating at cold plasma edge conditions would permit use of high-Z materlals with low sputtering cates which would reduce the problem's severity.

R\&D needs:

- Investigation of conditions necessary for operation at cold plasma edge conditions.

- Development of armor-to-structure attachment methods for maximum thermal conductivity to maxtmize allowahle armor thickness.

- Development of rapid I-C device changeout techniques and malntenance equipment.

\section{II.4.2 Tritium Contanination of Coolant in HHFC's}

Permeation rates of tritium from the plasma through armor (if present) and structural materials into coolant are largely unknown for the fusion environment. For water coolant, high levels of contamination will result in high costs for tritlum removal from the water and the unacceptability of the heated water for use in power conversion systems, a significant econoulc penalty in the case of Impurity contral components.

KaD needs:

- Basic research in tritlum barrier effectiveness: oxide fllms, coatings

\section{II.4.3 Safety of Liquid-Metal-Cooled FW/B with $\mathrm{H}_{2} \mathrm{O}$-Cooled HHFC's}

The use of 1iquid-metal-cooled FW/B concepts in conjunction with $\mathrm{H}_{2} \mathrm{O}-$ cooled HHFC's such as limiters or choke coils is presently perceived to entail significant risk of the occurrence of large-scale energy releases for some projected accident scenarios, Very little work-analytical or experimenta1-has been done to better quantify this risk.

If $\mathrm{H}_{2} \mathrm{O}$-cooled HHF''s are judged unaceptable for use w1th liquid metal FW/B concepts, the coaling problems for such HHfC's will become much more difficult since other coolants are significantly poorer from the therwalhydraulies standpoint. 
R6D needs:

- Testing to determine the probabilities of the Individual fallures and events necesgary to bring about large-scale energy releaseg in realistic configurations for $\mathrm{LM} / \mathrm{H}_{2} \mathrm{O}$ contact, using candidate 11quid metals.

- Probabilistic FMEA, using results from the above testo, to provide quantitative data sufficiently accurate to permit judgements of the acceptability of the risk.

\section{II.4.4 Effect of Impurity Control Devices on TBR for Tokamaks}

Impurity control options for tokamaks such as bottom pumped limtters and single- or double-null divertors take up significant breeding blanket volume. Unless realistic designs can be developed that incorporate breeding zones into these impurity control devices, their use may ultimately preclude the use of blanket concepts with lower potent1al TBR'g $\left(\mathrm{e} \cdot \mathrm{g} \cdot, \mathrm{LI}_{2} \mathrm{O} / \mathrm{H}_{2} \mathrm{O}\right)$.

R\&D needs:

- Englneering development of leading candidate impurity control options which include bzeeding zones with $\mathrm{TBR}$ values $=$ unity. 
1. พ. M. Stacey, Jr., et al., "U.S. INTOR Canceptual Design," USA INTOR/81-1, Volumes I and II, Georg1a Inst1tute of Technology,"1981.

2. M. Abdou, et al., "A Demonstratton Tokanak Power Plant Study (DEพO)," ANL/FPP/82-1, Argonne Natlonal Laboratory, 1982.

3. C. C. Baker, et al., "STARFIRE - A Commercial Tokamak FuBion Power Plant Study," ANL/FPP/80-1, Argonne National Laboratory, 1980.

4. J. L. Cecch1, "Impurity Control In TPTR," J. Nuc1. Matls. $93 \& 94,28$, 1980.

5. Personal communtcation, J. D. Gordon to G. D. Morgan, 1984 .

6. Personal communication, J. D. Gordon to G. D. Morgan, 1984.

7. B. G. Logan, et al., "Mirror Advanced Reactor Study - Final Design Report," UCRL-53460, Lawrence LIvermore NatIonal Laboratory (to be published).

8. Personal comantcation, J. D. Gordon to G. D. Morgan, 1984.

9. J. N. Downing, "High Heat FIux Technical Assessment Summary for Altemative Concepts," LA-UR-84-874, Los Alamos National Laboratory (to be pub lished).

10. R. A. Rrakowski, "Identification of Future Englneering Needs of Alternative Concepts for Magnetic Fuston Energy," LA-UR-83-1973, Los Alamos National Laboratory, 1982.

11. R. W. Motley, Nucl. Fus. 21, 1541, 1981.

12. V. S. Mukhovacov, V. D. Shafranov, Nucl. Fus. 11, 605, 1971.

i3. C. E. Wagner, "Possibility of Achieving Ignition in a High Field Ohmically-Heated Tokamak," Phys. Rev. Lett. 46, 654, 1981.

14. "Mirror Advanced Reactor Study - Final Design Workshop," Misc. Document 4167, Lawrence Liverwore National Laboratory, 1983.

15. M. A. Abdou, "Tritium Breeding 1n Pusion Reactors," ANL/FPF/TM-165, Argonne National Laboratory, 1982.

16. T. Ide, Y. Sek1, H. Alda, "Effects of Neutron Streaming through Injection Ports on Neutronlcs Character1stics of a Fusion Reactor," Proc. 2nd Topical Meeting on the Technology of Controlled Nuclear Fusion, CONF-760935R3, 395, 1976 .

17. J. Jung, $M$. Abdou, "Breeding Eotentlal of Candidate Breeding Materials," Nuc1. Tech/Fusion, 4(2), 361, 1984. 
18. 11. A. Abdou, et al., "Blanket Comparison and Selection Study - Interim Keport," ANL/FPP-83-1, Argonne National Laboratory, 1983.

19. Y-K. M. Peng, P. H. Rutherford et al., "FED A, An Advanced Performance FED Based On Low Safety Factor and Current Drlve," ORNL/FEDC-83/1, Fusion Engineering Design Center, Oak RIdge Nat1una1 Laboratory, 1983. 
GHAPTER II

SYSTEMS INTEGRATION

Lead Author:

G. D. Horgan (MDAC)

Contributors :

J. N. Downing (LANL)

J. D. Gordon (TRW)

J. Jung (ANL)

S. J. Plet (EGSG) 
III. MATERIALS AND PROCESSES

\section{III.1 opereting Condittons}

The establishent of the plagms edge and acrape-off parameters represents the starting point in deteraining the operating environment for impurity control componente. For tokaukg, the critical paraneters in the scrape-off layer are plasma density $n_{e}$, electron- and 1on-temperature $T_{e}$ and $T_{1}$ and charactertsesc decay lengths $\lambda_{r}$ and $\lambda_{q}$ of particle and power flux respective1y. For reactor relevant plabma operation the plasma density in the scrapeoff layer can vary between $10^{12}$ and $10^{13} \mathrm{~cm}^{-3}$ wth electron- and iontemperatures on the order of $100 \mathrm{ev}$, fon fluxes parallel to the agnetic fleld of $s_{1}=3 \times 10^{19} \mathrm{~cm}^{-2} \mathrm{~s}^{-1}$ are posstble at the plagma boundary. Along with the corresponding electron flow, this can result in heat fluxes of several $\mathrm{kw} / \mathrm{cm}^{2}$ perpendicular to the magnectc fleld. Particle and heat fluxes of this order are measured in present devices. In order to accommodate these heat fluxes, 11miters and divertor collector plated are ohoped to spread out the heat fluxes over a large area. Several actively cooled systens for future machlneo are designed for heat fluxes of 3-5 $\mathrm{MH} / \mathrm{m}^{2}$. The cortesponding particle fluxes are of the order of $=2 \times 10^{18} / \mathrm{cm}^{2}-6$. In addition $t$ particle and power flures, the corresponding decay lengths in the scrape-off layer have to be known for the design of limiters, divertor plates and RF-antennae. Stnce the characteristic decay lengths $\lambda_{q}$ and $\lambda_{p}$ depend on the 11miter configuration 1tself as well as on perpendicular and parallel sransport, they cannot be predicted accurately and have to be parameterized. A reasonable range for $\lambda_{q} 18$ 0.5 to $5 \mathrm{~cm}$, where $1-3 \mathrm{~cm}$ seens to be nost Iflely. The corresponding length for the partiele flux, which lo loportant for the design of pump Ifmiters, Is nownally $(5 / 3) \cdot \lambda_{q}$ at $T_{e}=T_{l}$.

The operacing environment experfenced by Impurity control componente in tokamaks w11 vary with the time frame of the device beting considered, as ohown in Iable III-1. In general, burn lengths, avallabllity, neutron wall loading, and neutron fluence will increase in golng from near tert to long term devices. The oufface heat flux to these components is not expected to vary greatly from the heat loads geen in present deviceg, but the requirements For heat renoval w111 change as the burn length increaseg. The total number 
Table III-1. Inpurity control garaseters - Toksaba

\begin{tabular}{|c|c|c|c|c|}
\hline racandut & $\begin{array}{l}\text { Preasent Machines } \\
(0-3 y)\end{array}$ & $\begin{array}{l}\text { kear Tetm } \\
(3-8 y)\end{array}$ & $\begin{array}{l}\text { ETR'0 } \\
(19900)\end{array}$ & $\begin{array}{l}\text { Long Jer" } \\
(12000)\end{array}$ \\
\hline Heat Plux & $\begin{array}{l}4 \mathrm{mu} / \mathrm{s}^{2}-1.58 \text { (TFTR) } \\
70 \mathrm{~mW} / \mathrm{s}^{2}-.25=(\mathrm{TFTR})\end{array}$ & $\leq 5 \mathrm{mw} / \mathrm{m}^{2}$ & $\leq 5 \mathrm{MH} / \mathrm{m}^{2}$ & $\leq 10 \mathrm{mH} / \mathrm{m}^{2}$ \\
\hline Heutrun niux & 0 & $1-2 \mathrm{mw} / \mathrm{s}^{2}$ & $1-2 \mathrm{~m} / \mathrm{m}^{2}$ & $2-5 m / a^{2}$ \\
\hline Meution Fluence & 0 & $<1 \mathrm{dpa}$ & $-20 \mathrm{dpa}$ & - $50 \mathrm{dpe}$ \\
\hline Durn THe & $0.2-5 \mathrm{a}$ & $20-300 \cdot \operatorname{TFCX}$ & $200 \cdot$ Itror & Cant. \\
\hline Structurel Mater1z: & $\begin{array}{l}\text { Hickel sase Alloys } \\
\text { Statnleas Steel }\end{array}$ & Copper Alloys & $\begin{array}{l}\text { Copper Alloys } \\
\text { Refrectory Hetele }\end{array}$ & $\begin{array}{l}\text { Gopper Alloy" } \\
\text { Refractory Hetais }\end{array}$ \\
\hline coolent & Mone & Hater & Water & $\begin{array}{l}\text { Huter } \\
\text { Liquid Metel. }\end{array}$ \\
\hline Edge Tezererature & $10-100 \cdot v$ & $-100 \mathrm{eV}-\mathrm{TFCX}$ & $\sim 20-100$. INTOR & $20-100$ aV - Tokmaks \\
\hline Corfiguration & $\begin{array}{l}\text { Tlles Mechanicalty } \\
\text { Atrached to llest sink }\end{array}$ & $\begin{array}{l}\text { Costing/cladding bonded } \\
\text { co liest SInk }\end{array}$ & $\begin{array}{l}\text { Costing/Cladding Bonded } \\
\text { to Hest SInk }\end{array}$ & $\begin{array}{l}\text { Conc1ng/Clindding Bonded } \\
\text { ta Heat slnk }\end{array}$ \\
\hline \multicolumn{5}{|l|}{ Operating Teuperaturc } \\
\hline $\begin{array}{l}\text { Surface } \\
\text { Heat Sink }\end{array}$ & $\begin{array}{l}800^{\circ} \mathrm{C}-1800^{\circ} \mathrm{C} \\
200^{\circ} \mathrm{C}\end{array}$ & $\leqq 1000^{\circ} \mathrm{c}$ & $\geqq 4000^{\circ} \mathrm{c}$ & $\begin{array}{l}\leqslant 1000^{\circ} \mathrm{C} \\
\left\{750^{\circ} \mathrm{C}\right.\end{array}$ \\
\hline Number of cycles & $10^{5}$ & $-10^{5} \operatorname{TrCX}$ & $-10^{6}$ (INTOR) & $<10^{3}$ \\
\hline Surface Mater1al: & $\begin{array}{l}\text { Graphite } \\
\text { TiC, Sic conted Graphite } \\
\text { te }\end{array}$ & $\begin{array}{l}\text { Be } \\
\text { sic } \\
\text { Beo } \\
\text { c }\end{array}$ & De & $\begin{array}{l}\text { se } \\
\text { Ia } \\
\text { y }\end{array}$ \\
\hline
\end{tabular}


of burn cycles w11 decrease for long term derlces as the burn lengths move towards ateady state operation.

The operating parsineters of Impurity control components in drrors will be sluilar to those 1n tokanaks in terms of operating tenperatures and heat fluxes. Therefore, the candidate materials considered for wrrors are the same as for tokanaks. There are sone diffeiences expected in the operating conditions, however, which could influence the final cholce of waterials. Mirrors are expected to operate in a continuous node, and the total number of operating cycles will be greatly reduced compared wh near teru tokamaks. The plasna edge (or halo) tenperature any also be different in elrrors. Present analyses Indicate that the halo cemperature w1ll be $\sim 10$ eV compared with - $100 \mathrm{ev}$ for the plasma edge In tokanaka. Finally, the total anount of radiation dasage experlenced by topurity control aterials in wirrors way be reduced conpared with tokanaks, since these components are located in the mirror end celis where the neutron flux 18 ouch lower than in the central cell.

Auxillary heating components including neutral beam dumps, RP antennas, and wavegulde domes, are likely to experlence high heat fluxes. Beam dumpa for present systems are designed to accomodate very high heat fluxes, and they are all composed of water cooled, copper alloy heat sinks. Future beam dump conditions and designs are likely to be alwilar to those in present systems. RF antennas and wavegulde domes will be directly exposed to the plasma and neutron flux, and therefore they will experience roughly the same enviranment as the lifiter blades and divertor collector plates. In addition, however, there are additional electronagnetic requirenents placed on the materials used for these components. Copper alloys will be used for both thetr high thernal and electrlcal conductivity, whlle ceranics will be tused prinarIIy for their electrical Insulating properties. Beo, for example, is used as the waveguide done naterial in most designa because of the high trangparency to the RP waves.

\section{III.1.1 Requirements and Condidate Materials}

There are number of requirewents for the high heat flux waterials. The ability to withstand high heat flus.es depends to a great degree on the thermophysicai propertes of the aterial. In particular, the materials should have a high thermal conductivity, high apecific heat, a low coefficient of therwal 
expanoion, and a low elautic sodulus to mininize tiesal gradients and ctresses. The zaterlals should exhibit wechanical propertles which guarantee structural integrity for the desired operating lifetine of the comoneat. The nechanical properties of 1mpartance are tenalle, creep, fatigue, and crack growth. The terials used in devices that produce high neutron fluences should be resigtant to radiation danage. Both the thermophysical properties and nechanical properties thould not be signiftcantly degraded by radiation. In addition, the materials should be reagonably resistant to dimensional changes caused by radiation induced owelling and creep. The naterials should also be capable of being fabrlcated 1nto the complicated geonetry of high heat flux components. Besides the usual fabrication conslderations, it is iwortant that the aaterials are capable of being successfully joined together. The property requirements for the joint: are the same as the bulk materials. Finally, the materlals should not be a significant source of plaga contanination. The properties of Inportance relate to the interactions of the plasia with the material's surface, which are described in detall in the PHI task group technical assessment. The selection of the naterial which to exposed to the plasma will depend on the plasma edge condittons as deacribed below.

In most cases, no single material can be identifled that satisfles all of the requirements for high heat flux conponents. For example, the opeclal requirements needed for plama-naterfals interactions lead to chofces that are not generally considered to be structural naterials. Therefore, at least in the aree of imurity control, the materials are divided into the classeg of plasms side naterials and heat sink materials. In the case of bean dutups and other components that do not interact directly with the plabus edge, only the heat sink naterials usually need to be considered. When both a plasma side material and heat siok material are requited, they are usually deaigned to be netallurgically bonded together. Thus, the behavfor of bonds 18 also an important consideration for high heat flux components.

The cholce of a plasm side naterial is atrongly Ini luenced by the plasna edge conditions. The ajor concerns are the potential for plasua concentnation as a result of physical sputtering from the surface and the possibllity of rapid erosion leading to short lifetiwes for these components. The sputtering race to dependent on the Incident particle energy, nasa, and flux. It 1. expected that sputtered anterial whl eventually return to the surface to 
cause additional sputtering. The wost iportant paraneter lufiuencing material delection is the plasus edge temperature. At low plasm edge temperatures ( $\leq 50 \mathrm{eV}$ ), the $\mathrm{bfgh-Z}$ aterials such as tungsten or tantalun are preferred because the net erouton rates are predicted to be esaentialiy zero. At higher edge cenperatures, it is predicted that oputcered particles from high-z surfaces w11 return to the surface at e.ergles oufficlent to gield self sputtering coefficlents greater than unity resulting in an unacceptable eputtering cascade. The only materials that could be used under these conditions are those whose self-sputtering coefficlents never exceed unity. The elenents which meet this criteria are those with atoulc numbers below that of silicon. The low- $Z$ materials that have been exantned nost closely are Be, $C, B e 0$, and SiC. These naterials weet both the sputtering requirewent and the requirement to be able to accomodate high heat fluxes.

The primary requirewents for the heat ank usterials are the ability to accommodate high heat loads and the ability to maintain structural integrity over the I1fetime of the corponent. The First requiresent leajo to the selection of high thermal conductivity alloys as candidate aaterlals. High conductivity alloys that are presently avallable In large quantfties are aluminum and copper alloys. Copper alloys have recelved greater attention primarily because of theli abllity to operate at higher temperatures compared with aluninum alloys. Other alloys that also offer potential are transition metals buch as molgbdenum, vanadiun, nlobium, and tantalum. These metals are capable of operating at very high tenperatures and are conpatible with 11quid wetal coolants. The becond requirement 18 more difficult to assess because of the lack of daca for many propertles that are relevant to long term operation.

\section{III.2 Plaga Side Materialo}

The propersles relevant for plasna side materlals Include the ourface, physical, mechanical, and irrsdintion properties. The surface properties that are Important in plasma-naterials interactions are covered in the technical assegsment report of the PMI Task Group, and only a brlef sumary ts presented here. The other properties are diacussed in greater depth. 


\section{III.2.1 Surface Properties - Interfece with PuI}

The chofee of plasin alde witerials 1s strongly restricted by plasua operation. Processes ifke spucterlng, srclag, and evaporation contaninate the plases wth impurities the radiation of wich constitutes an energy loss channel. To keep the radiation lostes on a tolerable level, efther the atonic number $z$ of the material has to be low or the fupurity production process has to be nininized. At present, it is not knom how to cool the plasus edge aufficlently to prevent afuttering; hence. $10 \mathrm{~m}-\mathrm{z}$ aterials, such as graphite sre selected. If the plaswa edge can be cooled down below the sputtering threshold, which goes up with tncreasing $Z$ of the miterial, it alght be possible to ut1lize higher-z materials 11ke; molybdenu, or tungsten.

The processes that contalnate the plama with wall lapurftied represent at the same time erosion wechaniang for the first wall components. Pregent aschines operate in a short pulse, low duty cycle node and the Impurity aspect Ig the doninant concern. In contrast, surface erosion is likely to be the downent lssue In future devices which are betng destgned now for long pulae and high duty cycle operation. Extrapolating plasma parameters of present nachnes, erosion rates of several cn per year have to be accomodated. consequently, unless the plasna edge tenperatures can be reduced belon the sputtering threehold, thin wall designs for renoval of high heat fluxes cannot be ut111zed.

The najor materfalo processeg of interest are phystcal sputtering," chentcal sputtering, and hydrogen (heliun) 1mplantation and release. The integration of these effects with the fuston environment is predicted to result in continuous erosion and redeposition of the plaswa side surfaces during $r$ stal operation. Although there is a significant data base for sputtering and hydrogen fuplantation and releage, there are essentially no aaterials data on the coabined erosion and redeposition expected in fusion devices.

\section{III.2.2 ABneganent of Plagng S1de Materials}

The candidate plasa side matertals Include the $10 \mathrm{r}-\mathrm{z}$ candidates Be, $\mathrm{C}$, SIC and beo, and two high-z candidates $W$ and Ta. A detalled data bate for these aterials is presented in Ref. 1. The physical and mechantcal propertiea of theie candidate low-Z nateriala, and presunably also other candidateo such as $B, D_{4} C$, TIC, etc., are strongly dependent on the fabricition wethod 
and on the product forw. This results in a range of property values encountered in the Ittarature, and requires a careful selection of properties to be used in design with these aterials. The properties of all of these materials can be affected by 1rradiation, altiough data are sparse for irradiation conditions that adequately simulate fuston reactor service. Berylilum metal is unique in the lor $\mathrm{Z}$ candidates in that tta theral conductivity is not affected by irradiation; for the other $10 \mathrm{w}-\mathrm{z}$ candidates the thermal conductivIty is rapidly degraded by neutron irradiation.

The physical properties of the high-z candidate materials are well understood, and are relatively Iosensitive to product form and fabrication technique. Relatively few daca are avallable on irradiation effects on $W$ and $T a$ but 11tcle change to expected in thetr physical propertles during irradiation, and loss of ductility can be expected if bervice temperatures are relatively low.

The properties and prospects of the plasm side materials were sumnarized by the FED/INTOR project. The following naterlal 19 extracted from that sunmary. Representative property values for $10 \mathrm{w}-\mathrm{Z}$ and $\mathrm{h} / \mathrm{gh}-\mathrm{Z}$ candidace plasma side materials are presented in Tables III-2 and III-3, respectively (from Ref. 1).

Beryllfum has a very low atomic number, good thermal conductivity and heat capacity and relatively high heats of vaporization and fusion. Graphite has many attractlve properties Inciuding a wuch higher melting temperature; it pormally tends to vaporize before meltiu-. The vaporization rate becomes excessive at temperatures above $\sim 2000 \mathrm{~K}$. Although graphite has a relatively high therasl conductivity at Iow temperatures, the conductivity is rapidly reduced at relatively low radiation levels ( $<$ I dpa). Silicon carbide also tends to decompose and vaporlze before melting, and therefore, avolds the melt layer problem. However, the maximum operating temperature $(\sim 1700 \mathrm{~K})$ and the thermal shock resiatance of \$IC are generally lower than thoge for graphite. As In the case of graphite, the low-temperature thermal conductivity of S1C decreases rapidly with radiation fluence. The BeO has high melting temperature, high thernal conductivity et low tenperatures, and is not belleved to be susceptible to chemtcal sputtering. Although data for the liquid phase are sparse, calculationg tndicate that a thin welt layer will form on Beo during a disruption. This comnrund is also susceptible to rapid deterioration of the low temperature thermal conductivity at tow neutron fluences. 
Table III-2, Property Valucs at $800 \mathrm{~K}$ for Low-2 Mater1als

\begin{tabular}{|c|c|c|c|c|}
\hline \multirow[b]{2}{*}{ Property (OnitB) } & \multicolumn{4}{|c|}{ Property Yalue } \\
\hline & Be & $\mathrm{BeO}$ & $\mathbf{C}$ & S1C \\
\hline Melting Temperature (K) & 1557 & 2823 & - & - \\
\hline Sublimation Temperature ef $10^{-2} \mathrm{~Pa}(\mathrm{~K})$ & & & 2300 & 1800 \\
\hline Density ${ }^{\mathrm{a}}\left(\mathrm{Mg} / \mathrm{m}^{3}\right)$ & 1.85 & 3.01 & $1.8^{b}$ & 3.20 \\
\hline Thermal Expansion, $300-800 \mathrm{~K}\left(10^{-6} \mathrm{~K}^{-1}\right)$ & 15.9 & 8.2 & 4.2 & 4.9 \\
\hline $\begin{array}{l}\text { Thermal Conductivity (W/mK) } \\
\text { Unfrradiated } \\
\text { Irradiated }\end{array}$ & $\begin{array}{l}103 \\
103\end{array}$ & $\begin{array}{l}68 \\
36\end{array}$ & $\begin{array}{r}103 \\
25\end{array}$ & $\begin{array}{r}37 \\
9\end{array}$ \\
\hline Spectflc Heat $(\mathrm{J} / \mathrm{kgK})$ & 2250 & 1840 & 1620 & 1150 \\
\hline $\begin{array}{l}\text { Young Modulus (GPa) } \\
\text { Infirradiated } \\
\text { Irfadiated }\end{array}$ & 190 & $\begin{array}{l}36 \\
-\end{array}$ & $\begin{array}{r}8 \\
18\end{array}$ & $\begin{array}{l}400 \\
400\end{array}$ \\
\hline $\begin{array}{l}\text { Yield Strength (MPa) } \\
\text { Unirradiated } \\
\text { Irradiated }\end{array}$ & $\begin{array}{c}200 \\
-\end{array}$ & $\begin{array}{l}76 \\
-\end{array}$ & $\begin{array}{l}14^{\mathrm{d}} \\
2 l^{\mathrm{d}}\end{array}$ & $\begin{array}{l}360 \\
360\end{array}$ \\
\hline Elongation, irradiated ${ }^{c}(z)$ & 5 & $<1$ & $<1$ & $<1$ \\
\hline
\end{tabular}

Density at $300 \mathrm{~K}$.

$b$ Density of Graphite Ránges up to $2.25 \mathrm{mg} / \mathrm{m}^{3}$ Depending on Product Form.

c High Flueace Irradiation Properties.

d Tensile Strength for Graph-N3M is about $470 \mathrm{MPa}$ (Untrradiated), Estimated $230 \mathrm{MPa}$ After High Yluence Irradiat1on.

Table III-3. Properties of Hgh-Z Materlals at $500 \mathrm{~K}$

\begin{tabular}{|c|c|c|}
\hline Property & Tungeten & Tantalum \\
\hline Atonic Weight & 183.85 & 180.95 \\
\hline Density, $g / \mathrm{cm}^{3}$ & 19.25 & 16.6 \\
\hline MeIting Point, ${ }^{\circ} \mathrm{K}$ & 3683 & 3269 \\
\hline Thermal Expansion, $\times 10^{-6} \mathrm{~K}^{-1}$ & 4.2 & 6.58 \\
\hline Thermal Conductulty, $W / m^{\circ} K$ & 145 & 61.8 \\
\hline Heat Capacity, J/kg・K & 138 & 148 \\
\hline Madulus of Elasticfty, GPa & 398 & 176 \\
\hline
\end{tabular}


The non-netala $G$, SIC and BeO all have relatively high therwal conductivities at low temperature. However, radiation reduces the conductivity of thege types of aterials. Although conelderable effort has been expanded to develop high conductivity sic, it lo not clear that the high conductivity can be maintained in the radiation environment. The thermal conductivities of these types of materials generally decrease elgnificantly as the temperature 19 Increased above room temperature. For example, the thermal conductivity of the CVD $8 \mathrm{SIC}$ Is about a factor of $2 \mathrm{higher}(67 \mathrm{~W} / \mathrm{m} \cdot \mathrm{K})$ at $25^{\circ} \mathrm{C}$ than at $525^{\circ} \mathrm{C}$. Under 1 rradiation the conductiulty tends to become insenstive to temperature at values slightly below the bigh temperature values. Other compounds such as $\mathrm{B}_{4} \mathrm{C}$ and $\mathrm{Al}_{2} \mathrm{O}_{3}$ show siatlar behavior. Limted data also 1ndicate that the low temperature thermal conductivity of Beo decreases rapidiy with radiation fluence.

Tungsten and tantalun are of interest for the plasme side materials becave of their low light-ton sputtering ylelds at low plasma edge temperatures, their relatively high threshold energy for Dr sputtering, and their relatively high energy ( $700 \mathrm{eV}$ ) at which self-sputtering exceeds unity. Values for the phystcal properties of tantalum and tungsten at temperatures In the range of Interest are summarized In Table III-3. Only 1Imited date exlot on the effects of radiation on the properties of tungsten and cantalum. The ductile-brittie trangition temperature (DBTT) of cungsten 19 increased from 65 to $230^{\circ} \mathrm{C}$ after fast reactor irradiation at $385^{\circ} \mathrm{C}$ to tluences of $4-9 \times 10^{25}$ $\mathrm{n} / \mathrm{m}^{2}$. At higher fluences $\left(1.5-4.4 \times 10^{26} \mathrm{n} / \mathrm{m}^{2}\right)$ and simllar temperatures the unfform elongation of tantalum was reduced to $\sim 0.1 \%$ with a total elongation of B-IO\%. Limfted data Lndicate excellent law-cycle fatigue resistance of tantalum at temperatures below $732^{\circ}$. C.

The avallable data on the phystcal and mechanical properties of plasma side materisis are adequate for conceptual destgn with these materials, provided the data are used with the awareness of the product-form dipendence for the low-Z candidates. However, detalled design 11 require qualification testing and messurement of critical properties on prototype component raterlals. The effects of neutron Irradiation on the critical propertles are not known well enough for prediction of service behavior. The strong dependence of property responge on irradiation temperature will require the irradiation of appropriate product form of the low-Z materials trder conditions judged to 
adequately simulate service conditions. Important property measurements must Include conductivity and otrength properties, using tests specified to demonatrate the ability of the aterial to withotand oervice stresges. Changes In physlcal properties of high-z candidates during Irradiation are not a concern, but verification of adequate ductility after irradiation may require additional experfmental work.

\section{3 Heat Sink Haterlalg}

The heat aink mat provide atructural support for the plagma side materlal (1r used) and provide for heat removal, normally by flowing coolant through the heat sink. The materlal used for the heat sink should exhibit good strelisich and ductility, high thermal conductivity, good fabricability, and reasonable cost. In the long term, the heat sink material should also exhlbit good radiation damage resistance. For the next generation of derices, the heat sink material 18 almost certaln to be a copper alloy, and the coolant w111 be low temperature water. For DEKD and beyond, refractory metal alloya of $\mathrm{Y}$. $\mathrm{N}, \mathrm{Ta}$, and $\mathrm{No}$ are aloo being considered. The coolant could be either water or a liquid metal, such as lithium.

\section{3 .1 Copper A11oys}

\section{III.3.1.1 Phys1cal and Mechantcal Propert1es}

Copper and copper alloys are leading candidates as the heat sink materla1. They are characterized by high thermal and electilcal conductivity and, In general, corrosion resistance to flowing water. There is a large Industry tullt up to produce and fabricate copper forms and products. Unfortunately many copper alloys have not had their phyalcal anc mechanical propertiea adequately measured, particularly at temperatures of intereat: room temperature to $500^{\circ} \mathrm{C}$.

Table III-4 gives a listing of candidate heat sink copfer alloys includIng conpositlon, roon temperature yleld strength and thermal conductivity. Copper allaye, se wh tost materials, can have thetr phystcal and mechantcal properties changed wdely by thermal-mechanical treatwents (TMTs). Copper alloys tend to have their cold wort and precioftation hardening effects annealed out by terperatures in the $200-550^{\circ} \mathrm{C}$ range. Thus, for sone 
applications the use of cold worked and aged copper alloys may not be posalble Wthout overaging.

Of the nine copper alloys 11ated, only OPHC Cu and CuAg can be considered to have an adequate unirradiated physical property data base for the temperatures of interest.

The physical properties of the other beven alloys have, In general, been ponrly measured or only eatinated fron values neasured for almilar alloye or extrapolated to higher tenperatures from low temperature measurements taken for the same alloy. The physical properties: thermal conductivity $\left(k_{T}\right)$, electrical conductivity $\left(k_{p}\right)$, spectetc heat $\left(c_{p}\right)$, coefficient of chermal expansion $(\alpha)$, Polsson's Ratio $(v)$ and elastic modulus $(z)$ all need to be mea$b$ : sed from room temperature to $500^{\circ} \mathrm{C}$ for the copper alloys (except for opHC $\mathrm{Cu}$ and CuAg) shown in Table III-4. In some cases the alloys need to be measured In several Thi conditions. These would include such conditions as annealed; solutionized and aged; solutionized, cold worked and aged; and solutionized, aged and cold worked.

The mechanical properties of copper and copper alloys have not been adequately charactertzed. The alloys $O F H C$ Cu and CuAg have been studied a great deal more than any of the other candidates. As with the phys1ca1 properties, a great deal of the avallable data 18 for room temperature properties. Because of the relatively low temperature nature of copper alloys, creep and ereep-fatigue behavior 1s 1mportant even at temperatures as low as $150^{\circ} \mathrm{C}$."

present-day devices operate under low thermal loadings. Levices being designed and bullt now wll experience higher loadings, especially in heat slinks for llatters, bean dumps and collectorz for divertord. These greater thermal loadings will lead to higher thermal stresses, which combined with the electromagnetic and coolant stresses will force the selection of higher otrength copper alloys buch as rube alloys, dispersion gtrengthened alloys, or CuCrZrMg alloys,

The methanical propertles that most need to be measured for copper alloys Include:

- censlle propertles as $\mathrm{f}(\mathrm{T})$ from room temperature to $500^{\circ} \mathrm{C}$

- fat1gue behavior (low cycle temperature to $300^{\circ} \mathrm{C}$ )

a creep behavior

- creep-fatigue L.scaraction 
Table III-4. Candidate Heat Sink Copper Alloys

\begin{tabular}{|c|c|c|c|c|c|c|c|}
\hline Alloy & Designaticn & $\begin{array}{c}\text { Nominal Composition } \\
\text { Wt. } z\end{array}$ & $\mathrm{MPa}^{0.27}$ & $\begin{array}{l}Y 5^{a} \\
(k s i)\end{array}$ & $\underset{w / m-\frac{m}{m}-{ }^{\circ} K}{k^{a}}$ & ${ }^{\circ} \mathrm{C}$ & $\left({ }^{\circ} \mathrm{F}\right)$ \\
\hline oftc Copper & $\mathrm{Cl0100}$ & $\mathrm{Cu}$ & $\begin{array}{r}70^{\mathrm{b}} \\
310^{\mathrm{c}}\end{array}$ & $\begin{array}{l}(10) \\
(45)\end{array}$ & 398 & 1083 & (1981) \\
\hline CuAg & C10700 & $\mathrm{Cu}-0.085 \mathrm{Ag}$ & $\begin{array}{r}70^{\mathrm{b}} \\
310^{\mathrm{c}}\end{array}$ & $\begin{array}{l}(10) \\
(45)\end{array}$ & 388 & $108: 3$ & (1981) \\
\hline Cu2t & C15000 & Cu-0.15zr & $360^{d}$ & (52) & 349 & 980 & (1796) \\
\hline CuAgPMg & 015500 & $\mathrm{Cu}-0.06 \mathrm{Ag}-0.06 \mathrm{P}-0.11 \mathrm{~kg}$ & $475^{d}$ & (69) & 348 & 1078 & (1972) \\
\hline CuzrCrMg & C18100 & $\mathrm{Cu}-0.4 \mathrm{Cr}-0.15 \mathrm{Zr}-0.06 \mathrm{Mg}$ & $510^{d}$ & $(74)$ & 320 & 1075 & $(1967)$ \\
\hline $\operatorname{Cos}_{2}{ }_{3}$ & C15720 & $\mathrm{Cu}-0.2 \mathrm{Al}_{2} \mathrm{O}_{3}$ & $490^{c}$ & (71) & 353 & 1082 & $(1980)$ \\
\hline cuce & C18200 & $\mathrm{Cu}-0.9 \mathrm{Cr}$ & $450^{d}$ & (65) & 323 & 1070 & (1958) \\
\hline CuBenii & C17510 & $\mathrm{Cu}-0.4 \mathrm{Be}-2.0 \mathrm{~N} 1$ & $\begin{array}{l}620^{\prime:} \\
760^{d}\end{array}$ & $\begin{array}{r}(90) \\
(110)\end{array}$ & 249 & 1004 & $(1840)$ \\
\hline CuBe & c17200 & $\mathrm{Cu}-1.9 \mathrm{Be}$ & ${ }_{1255^{d}}^{1105^{e}}$ & $\begin{array}{l}(160) \\
(182)\end{array}$ & 94 & 865 & $(1590)$ \\
\hline
\end{tabular}

a Room Tenperature.

b Annealed.

c Cold Firked $37 \%$ (Hard).

d Cold Worked and Aged.

e Solutionized and Aged. 
These wechanfcal properties, as wh the phyalcal pioperties, need to be measured for the alloys in varlety of Tnr condtitions. In sone cases these TMT conditione w11 be defined by the fabrication wieps necessary to form and join the heat oink naterials.

\section{III.3.1.2 Irradiation Effects}

The Irradiation data base for $\mathrm{Cu}$ and $\mathrm{Cu}$ alloys 1s sparse. Both neutron and Ion Irradiations have been utilized In the study of copper, but the fluence levels have been generally linited to less than $1 \mathrm{dpa}$. SweIling in pure copper has been measured at a fluence level of $0.3-0.5 \mathrm{dpg}$. The swelling is characterfzed by a peak at $\sim 325^{\circ} \mathrm{C}$ and a swelling rate of $\sim 17 / \mathrm{dpa}$. Alloying wh smait amounts of aluninum, gernanlum, gllicon, or nickel can result in reductions in awelling, whereas alloying with small anounts of Bliver or cadmium can Increase swelling.

The effoct of radiation on the mechanical propertiea of pure copper to to Increase the tensile strength and reduce the ductiltiy. Again, however, data exists only for low fluences, so that it to not possible to predict the changes that would occur at levels of 10-50 dpa.

The information needed to design high heat flux compnents in a neutroa ffeld is low-moderate temperature $\left(<400^{\circ} \mathrm{C}\right)$ and low-moderate fluence $\leq 50$ dpa) data on a varfety of copper alloys. The irradiation properties of greatest Interest are swelling, radiation creep, tensile propertles, and fatigue/ crack growth. A major obstacle to obtaining this information to the lack of low temperature frradiation test facilities in the Unted states. The two candidate reactors are $O R R$ and HFIR located at ORNL. However, ORR is capable of producing only $\sim 7 \mathrm{dpa} / \mathrm{y}$. HFIR to capable of producing $\sim 30 \mathrm{dpa} / \mathrm{y}$, but only in high flux regions where the temperatures cannot be easily controlled. Considerable work $1 \mathrm{~s}$ requited to develop instrumented assemblles for temperature control in test reactors.

\section{III.3.1.3 Coolant Compat1b111ty}

While copper ofructure would not be compatible th a 11quid metal coolant, copper and its alloye should be corrosion restatant to pure water in the absence of oxidizing agents. However, this resistance would be severely reduced if suall concentrations of hydrogen peroxlde and oxygen are present in 
the water from radiolyots. The nagnitude of radiation-1nduced effects needo to be establighed by analyolo of existing data and by experiments with varging concentrations of axygen and hydrogen peroxide. The ube of a hydrogen overpressure to aininize the concentration of oxidizing may lead to enbrittlenent of the copper or copper alloy. Another effect that has to be cleariy established for the appropriate alloys is that of water velocity. At high flow rates, corrosion-erosion may occur. Thile no great effect of corposition variation on the general corrosion resiatance of copper alloys has been observed, alloying can Improve erosion resistance at high flow velocties. However, while alloy developrent for far-term applicatlons way be of heip in producing a more corroston- and erosion-reslacant copper alloy, the development of approprtate methods for the control of water chemistry would probably have the greategt effect on limiting the corroston of copper and copper alloys.

\section{III.3.2 Refractory Meta1s}

\section{II.3.2.1 Physlcal and Mechanical Fropertles}

The refractory metals fora a class of materlals that fall Into groups VB and VIB of the perlodic table. They are all body centered cublc (b.c.c.) in atomlc structize. The group VIB metals consist of chromium, molybdenum, and tungaten, and group VB metals consist of vanedium, nloblum, and tantalum.

Refractory metals are characterfzed by good thermal conductivity, low thermal expansion, high melting point, and generally high reactivity. The combination of good thernal conductivity and low thermal expansion gives this class of metals a capabilit; to accounodate high heat fluxes. The high neltIng points an that these metals can be used at much higher terperatures than are possible with copper alloys. Refractory metale are considered to be apeclalty netals, and, as such, there is a limited production capability. Table III-5 gives a listing of the candidate alloys along with their conpesition, yleld strength, elongation, tharmal conductivity, and welting points.

The physical propertfes of refractory netal alloyg are generally not well characterized. In any cases, property values are estinated from data taken uaing binliar a':loyz or at different tenperatures. The physical propertes of interest are the thermal corductivity, electrical conductivity, opecific heat, 
Table III-5. Candidate Refractory Metal Alloys

\begin{tabular}{|c|c|c|c|c|c|c|c|}
\hline Alloy & Composition & $\underset{\mathrm{MPa}}{0.27}$ & $\begin{array}{l}\text { ys } \\
\text { ks1 }\end{array}$ & $\underset{\pi}{\text { Elongation }}{ }^{a}$ & ${ }_{w}^{k} f_{\text {mo }}^{a}$ & ${ }^{\mathrm{MP}} \mathrm{C}$ & $\times 10^{-\frac{\alpha}{6}} / \mathrm{x}$ \\
\hline$v-15 c r-5 T 1$ & $\begin{array}{l}15-C \mathbf{r} \\
5-\mathrm{TI} \\
\mathrm{Ba} 1-\mathrm{V}\end{array}$ & 500 & 72.5 & 27 & 24 & 1900 & 9 \\
\hline$N b-12 r$ & $\begin{array}{l}\text { 1-Zr } \\
\text { Bal.-Nb }\end{array}$ & 200 & $29^{b}$ & $35^{b}$ & 45 & 2468 & 6 \\
\hline FS-B5 & $\begin{array}{l}27-\mathrm{Ta} \\
10-\mathrm{W} \\
\text { Bal.-Nb }\end{array}$ & 475 & 69 & 24 & 45 & 2468 & 6 \\
\hline TZM & $\begin{array}{l}0.5-\mathrm{TI} \\
0.08-2 \mathrm{r} \\
3 \mathrm{al}-\mathrm{No}\end{array}$ & 760 & $110^{c}$ & $16^{c}$ & 115 & 2610 & 5 \\
\hline Ta-10W & $\begin{array}{l}\text { 10-W } \\
\text { Bal.-Ta }\end{array}$ & 1100 & $160^{d}$ & $10^{d}$ & 53 & 2996 & 7 \\
\hline$T-111$ & $\begin{array}{l}8-W \\
2-B f \\
\text { Bal.-Ta }\end{array}$ & 895 & $130^{e}$ & $15^{e}$ & 53 & 2996 & 7 \\
\hline
\end{tabular}

a Room Temperature.

b $20 \%$ cold Worked.

Rully Annealed.

d As Wrought.

e Stress Relieved 1 h at $1100^{\circ} \mathrm{C}$. 
coefflelent of thermal expendion, Polsson's ratio, and elastic modulus. The aechanical properties of these aterials are 180 poorly characterized. The tensile properties (ultinate teolle strength), fleld strength, elongation have been seasured for nost alloye, but other properties, ouch as fatigue, creep-fatigue, and crack growth, have not been measured in any cases. In addition, the mechentcal properties can vary subetentially with the thermomechantcal treatrent, so that the properties should be measured for a reriety of treatments in order to optimize the alloy structure.

All refractory metals experience the phenomenon referred to as the ductle-brittle transition temperature (DBTT). The DBTT Is esgentially a range of terperatures below which a ductile material behaves in a brittle manner and falls at very low otrains. The group VIB metals which consist of chrodum, molybdenum, and tungacen have a characteristic DBTT well above room temperature, while the group VB metals have a DBTT well below toon temperature $\sim-200^{\circ} \mathrm{C}$. This temperature range is not fixed but can be eltker ralsed or lowered depending upon chemlstry or microstructure. For example, the 1nterstit1al elements such as $C, O, N$, and $H$ can have a significant effect on the ABIT, In that it can be raised as these lapurities are increased. Therefore, It 18 important to keep these inpurities as low as possible not only during manufacturing and assembly, buc also during the service Iffe of these materials. Another way of altering the DBTT 1s through the use of cold working. Sold working creates a heavy dislacation alcrostructure which tends to increage the metals' tolerance for interstitial elements and results in a lower DBTT. It is for thfo reason that the metals nolybdenun and tungsten are supplied in the cold wor: ed and stress relleved condition. The large anount of cold work makes subsequent working with these metals extremely difficult and essentlally makes welding inpractical because of the increases in DBTT. Por tungsten, cold working has been found to decrease the transition tenperature from $420^{\circ} \mathrm{C}$ for sintered (recrystallized) tungaten to sbout $100^{\circ} \mathrm{C}$ with 957 cold working. Even though cold working significantly reduces the transition terperature of tungaten, it w11 still be above room tenperatire. This neans that forming will have to be done hot. Alloying of tungsten and aolybdenum wth rhentu has aloo bern fixund effective in redscing the DBTT. At lon concentrations of rhenluw, cold wroking io usually used to seduce the DBTT to lower levelo than achleved in pure metals. At higher inn intratione, the 
naterial 1, usually supplied in the recrystallized condition. These alloys can be welded. These compositions are W-25Re and Mo-50Re.

Tancaluin, nloblum, and vanadiu have DBI well below rook temperature and, as a result, are alloyed for atrength 1aprovewents rather than to alter the - Aloys of these netals are auplied in the recrystallized condftion and ox all weldable. Typlcal alloys which are comerclally avallable and have a reasonable daca base are Ta (Ta-10W and Ta-8W-2.5W [T-111], Wb (Nb-27Ta-10H$0.82 \mathrm{r}$ [FS-85] and $\mathrm{Nb}-10 \mathrm{~W}-10 \mathrm{HF}-.01 \mathrm{Y}$ [C129Y] and $v(\mathrm{~V}-20 \mathrm{TI}$ and $\mathrm{v}-15 \mathrm{Cr}-5 \mathrm{TI})$.

\section{III.3.2.2 Irradiation Effects}

The 1rradiation effects data bage for refractory metals 18 11nited, although it 18 somewhat more exteng1ve than the data base for copper alloys. The 1rradiation propertles of greatest interest are sweli1ng, embrittlement, and ereep. The suelling in pure refractory metals has been measured, but in most cases, swelling in the candidate alloys has not. pure ilobluw, vanadiun, and tantalum exhlbit swelling peaks at 600,550 , and $650^{\circ} \mathrm{C}$ respectively. Swelling in pure molybdenum appears to be relattvely independent of temperature in the range from $433-700^{\circ} \mathrm{C}$. Thare is some evidence which Indfeates that refractory wetalg (b.c.c. structure) are Inberently wore swelling reslstant than allo;rs with an f.c.c. structure. Alloying of refractory wetals, such as the addition of citanilu to vanadium, can reduce or elfminate swelling. The major concerng with embrittlewent are the upward shift which ay occur in the ductile-brittle transition temerature (DBTT), and the possible occurrence of plastic Instability. In the case of wolgbdenun, the DBTT can be raised to $400^{\circ} \mathrm{C}$ by neutron Irradiation, whlle in the case of the vanadium alloy, VANSTAR-7, plastic Instability was observed at room temperature in samples 1rradiated to only .0095 dpa. Radiation creep has not been measured for any of the refractory netals.

\section{III.3.2.3 Coolant Cogpat1bility}

Refrectory netals such as nloblum, tantalum, vanadium, and molybdenum and thelt alloys, we highly resistant to dispolution by liquid necals. In certain casen, severe localized attack of mloblun and tantalun by alkalf netala can occur when the oxygen concentration of these refractory netals exceeds several hundred parte per million by welght. However, this tgpe of attack can 
readily be prevented by careful handing, alloying ( $\mathrm{Zr}$ in $\mathrm{Hb}$ and Hf in $\mathrm{Ta}$ ), and proper heat treatnent. Vanadium has not shown this type of "oxygen diseage" except for abnorally high oxygen concertrations whlch produce suboxides in vanadium. Apart from this corrosion reaction, the wajor general comatibilly concern for refractory setal: and alloys exposed to alkall metals is interstitial transfer (carbon, nttrogen, oxygen) and the subsequent effect on materials properties. Exanples of such reactions include oxidation of refractory metals in sodium or potassiun of high oxygen activity, thernal gradient-Induced trangfer of nitrogen or carbon rrom the hot section of a refractory metal loop to a cooler part, and the carburfation or nitridation of the refractory uetal (alloy) when a liquid netal circuit includes both the refractory metal and a ferrous alloy (in the lower temperature region). While such reactions have not been studied for every refractory metal alloy-11quic metal rople, sufficlent work has been done (particulary for 11thium, to understand the most 1mportant compatibility reactions and to know how to minfmize their effects, Needed work in this area would simply be testing an opt1mized system under prototyple conditions, paying particular attention to the effects of the projected higher flow velocities.

Relatively 11ttle 18 known regarding the corrosion of refractory netals and their alloys by water. Recent short-term tests of vanadium alloys in water at 260,273 , and $300^{\circ} \mathrm{C}$ have ylelded encouraging results in that only snall weight gains were messured. Presunably, the corrosion of such alloys was reduced by the presence of a thlo axide film. However, data for longer exposures under varying chenlcal conditions will be required before a particular alloy is deemed sultable for long-term gervice in water.

While vanadiun and other refractory netals can readily absorb hydrogen (whtch can be present from the reduction reaction or from intentional additions to decrease the oxygen concentration of the water), analggen of vanadiun alloys exposed for $100 \mathrm{~h}$ to $300^{\circ} \mathrm{C}$ water with a hydrogen overpressure did not reveal any signiflcant Increases in the hydrogen concentration of the specimens. It was thought that the oxide layer on these alloys also played a beneflc1al rote in this regard by reductng hydrogen aborption. Again, longertern terte with the approprlate alloys are reculred to deteralne hydrogen effect over exterded exposure pertoda. 


\section{4 Interface/Attachent}

\section{III.4.I Characteristich and Propertlea}

Hang high heat flux comonents 1211 require a bond tetween the plaswa side naterial and the heat sink. These materials nay have very dissinilar physical and nechanfeal properties, end therefoze they way be difficult to Buccessfully bond together. There are many types of bonds, Including brazes, diffuolon boads, explosive bonds, and fnorganic adhesives, which way be considered for application to high heat flux components. Pabrication techniques for several of these bonda are discussed in sec. IIL.5.

There has been extensive work performed on the bonding of different aateTials, but in general the bonds are developed for specific aterials combinatlons and operating conditions. Therefore, the use of previous bond development regults to predict the oond properties of furlon high heat flux comonents is of Ifnited value where the naterials combinations and environaente are unique. Spectfication of all the processing varlables which characterize the jolning process wil deteralne the conpatibility of each wateriala combiration. Given these complexities, it is clear that attenpts to mode1 sush systew from the established data base cannot be performed with ant degree of confidence. Purthermore, the residual stress distributions that characterizes a particulat foint after fabrication are extrenely conplex since they will depend upon the detalled knowledge of the materials properties and timetemperature history during the fabrication process. The theranl stresses that develop during fustor reactor operations will superimpose on the reofdual fabricatiou stresses and change the stress state in ways that are difficult to predict. Thus, experimental confirmation of component performance under a realietic simulation of the operating environment will be needed to evaluate bonds for high heat flux couponents.

\section{III.4.2 Irradiation Effects}

\section{III.4.2.1 Reeulte of Previoul Work}

The largest body of Infurmation found in the ilterature on the irradiation effects to the inlerface/attachnent reglon between $A$ coating and a subatrate nuterial was ufitten by Johnaon, et al, $(2,3)$ for the developont of 
low friction coatings for the breeder reactor. Fron this rather extensive progran, valuable 1noights can be gained from the resulto of 1rradiation testa on over one hundred coating/substrate conblnations as well as practical experlence regarding the length of time and the anount of effort required to successfuliy qualify a coating/aubstrate system for in-reactor application. While wany of the design goals for developing aterials for breeder reactor applications were unique (e.g., sodiun cospatible, low friction, close dinension tolerance), others such as nechanical integrity, irradiation rssistance and therwal cycling are very sinflar to those of high heat flux component des1gners.

The following observationa have been ade:

(1) Irradiation testing of ccited naterialo elialnated more coatings than ang other qualification test (e.g., theral cycling under stress, epoxy $11 \mathrm{ft}$ off, environmenta1). This was in opite of the fact that the theras cycling tests, for exanple, Involved larger number of cycles under nore severe thermal conditions than those experienced in the Irradiation cests. Irradiation effects, therefore, ast be a major consideration in the testing of conposite materials.

(2) No clear cortelations betreen teoperature, fluence and coating damage were apparent.

(3) The ability of the mechantcally bonded coatings, such as plasma-sprayed and detonation gun coatings, to survive irradiation appeared to be related to coating bond strength, interface stresses, and internal coating otresses. The high strength detonation gun costings with minimur therral expansion differences alncained their integrity while most plasm eproyed coatinge of the save composition but having lower bond strengths, falled by apalling. "Graded" plasus sprayed cortings were more realatant to irradiation-induced fallures than other plasing coatInga, and offered potential for further developaent.

(4) Metallurgically bonded costings, ouch as those produced by diffusion coating, electro-spark deposicion, explosive bonding, or weld deposition showed no observable deleterious effects of Irradiation (cracking, apal11ng or unbonding). 
The wechantamg of 1rradfation danage in the coated naterlals are not well understood. When postirradiaton tests are positive, sssurance is gained that the naterials wil perfor adequately; however, when opecimens fall the 1rra diation test the caite of fallure is often open to speculation. The danage mechanlsms that operate in metallic materials should also produce damage in coatings. For example, swelling or differential swelling in composite coatIngs may produce coating fallure. Sowe probable we hanlaxg (all of which require otudy) that could reault in coating fallure are ligted below:

(1) Point defect or trangmutation Induced stress at coating substrate interface, or within the coating.

(2) Irradiatiori induced changes in mechanical and thermo-phygical properties of both coating and gabstrate. Th1s lo particularly 1uportant if the duplex ayster mat withstand deformation.

(3) Impurity and transwutation product migration to the interface region.

$\because$ Gas migration when interface is under atress or malntains a thermal gradient.

(5) Intra-coating stresses as : function of coating thicknes.

(6) Differential swelling and thernal expansion.

\section{III.4.2.2 Reconendations}

Because of the aensitivity to process variables and the complexity of duplex or triplex gyatens, thenretical predictions of irradiation performance are of linted value. In order to adequately evaluate the integrity of the Interface between the coating and substrate, appropriate test specimens nust be subjected to serles of qualification teats. Frevlous experience in developing and qualifying coatinge for breeder reactor spplications shows that lead times of 6 to 8 years way be requized to screen, test and qualify coating Bubatrate combinations for 1rridiation perforance to a level of 20-30 dpa. 
The tine required for irradiation testing of Hor materiale is a function of the test temperature and fluence, spectwen configuration and sfize, and the irradiation factlity. Currently, relatively large HHF epecinens $(1.5 \mathrm{~cm}$ dia. $x$.1-1 cn thick) are belng irradiated in the 10 flux zones of the FFTF and EBR-II reactors. The afnimun bulk coolant temperature in these reactors is approximately $370^{\circ} \mathrm{C}$ which defines the lowest achlevable tenperature. It is anticipated that HAF testing will require irradiations in the $100-300^{\circ} \mathrm{C}$ range. Therefore, water cooled rixed apectrum reactors, the therwally controlled closed test loops in the FFTF, or eventually the FMIT, must be utilized.

While currently operating fission reactor facilitles will provide signiflcant defect dawage (dpa) and 1rradiation volume, they w111 not produce the correct soldd and gaseous trangmutation producte which are expected to strong1y effect the mechanical and physical propertles of the interface region. The FMIT, projected for operation in early 1990, w11 provide the correct transmutation to dpa ratios but within e very limited testing volume. All of the current and proposed test facllitfes have advantages and Ifmitations which must be carefully assessed when plannting our HHF Irradiation strategy.

\section{III.5 Fabrication}

\section{III.5.1 Plagma Side Materialg}

There are two alteinative epproaches to fairtcate surface armor of plasma side materials for high heat flux components. One lo to make a preformed cladding that is subsequently bonded to the heat sink by processes such as brazing, diffusion bonding or explosive welding. The ather to to deposit the plasma side material directly onto the heat sink by coating processes, such as vapor deposition or plasma spray.

cladding is potentlally wost attractive for applications requiring very thlck armor (several millimeters or even centimeters of plasma side material) applied to flat or nearly flat surfaces, such as divertor collector plates. The critical fabrlcation losues for claddings are related to the attachrent of the cladding to a heat sink. These attachent tsgues and assoctated regesrch requirements are discussed in a subsequent section of this document. 
Coatings offer distinct advantages over claddings in three areas:

surfacing of conplex shapes, e.g. curved linter blades, (2) coating of large area components, e.g. flrst wall, and (3) In-situ repalr of damage or eroded surfaces. At present, the prinary technology for conting high heat flux cowponents is chentcal vapor deposition (CVD) of thin $(<20 \mathrm{~m}$ ) layers of TIC onto graphite components. This technology has worked well in ISX-B and Doublet III, and TIC coated graphite will be used in TFTR.

Chenical vapor deposition is sultable for a large varlety of materials, Including metals (Be, Mo, Ta, $\mathrm{F}, \mathrm{Re}$ ), semiconductorg (B, S1), carbides (TIC, TaC, WC), nicrides, borldes, and beryllides. The primary disadvantage of CVD (and other vapor deposition technlqueg) for future applications lo low deposition rates, typically only merons per hour. Thus, it is not practical to bufld coating thicknesses comnensurate wh predicted erosion rates that range up to millimeters and even centlmeters per year. Many CVD processes also produce corrogive by-products and require high process temperatures that can adversely affect metal substrates.

Plasma opray coating is a promling technologg to overcome the linitations of vapor deposition. Industry experience has shown that nearly all metals spray well and can generally be deposited to thicknesses ranging from several millimeters to wore than one centineter. For example, beryllium and tungsten have both been deposited to thicknesses greater than one centimeter. Ceramle compounds that have a stable molten phase ( $\mathrm{BeO}, \mathrm{B}_{4} \mathrm{C}, \mathrm{MgO}$, $\mathrm{Al}_{2} \mathrm{O}_{3}, \mathrm{TH}_{2}, \mathrm{THC}, \mathrm{VC}$, etc.) can also be plasma sprayed, hut they are sometines more difficult to apply and residual stress limits raximum coating thicknesses of pure ceramic coartnge to a few millimeters or less. Materials that sublime or dissociate before they melt, such as graphite, cannot be plasma sprayed unless they are co-deposited whth at least $20 \%$ of a secont sprayable matertal to fom $3 a$ composite coating. Composite coatings of ceramics and metals (cermets), such as $S t C / A I$ and $S I C / N 1$, huve been plasma sprayed and look very promislig for high heat flux applications. However, these materials are still In the development stage. Graded mixtures of the heat sink and plasma side araterials can also be apray deposited to fabricate a smooth trangition zone between the substrate and surface coating. This may alleviate stress that is caused by the typlcally large mismacch In thermal expansion between candidate heat sink and plasma side materials. Segregation of mobile solutes, which 
tend to concentrate at sharp interfaces between disainilar materials, ay also be reduced.

In the past, the priuary disadrantages of plasus sprayed coatings have been high porosity (typically 80 to $95 \%$ of theoretical density) and poor adhesion in some cases. Recent advances in technology to spray coatings in an evacuated chamber (go-called low-preseure or vacuum plasma epray) have produced coatings ranging up to 997 of theoretical density with excellent adhesion.

An alternative coating approach to cope with high erosion rates is to develop techiology for In-situ vapor deposition or plasme spray costing inside a fugion device. This offers obvious advantages, elnce periodic recoating could be used to repalr eroded or damaged aurfaces. It would aloo pernt the uge of thinner coatings that would result in lower surface temperatures and reduced therwal otresses. Japanese and European researchers have begun preIIminary experfments to investigate poselble in-situ vapor deposition of THC and carbon. However, it appears that a long development effort will be required, and the prospects for success are open to question. At present, ingitú coating is perhaps best viewed as a very uncertald, long-range technology that has great potential benefit.

In summary, vapor deposition is a proven coating technology that has worked well in existing machlnes, but the prospects to extrapolate vapor depositton techniques to fabricete extremely thlck coatings are poor. Plasma spray coating has been successfully used to apply very thick cootings in industry. However, the materials of primary interest are not widely oprayed in Industry, and the limited data that are avaliable do not reflect recent advances in spray technology. It must be confirmed that theze materials can be eprayed to adequate thicknesses. Due to the unique microstructures of coatIngs, measurenents of coating properties ano testing in fusion relevant environments are also needed to establish the sultabllity of these coatings for hIgh heat flux surfaces. Technology for non-destructlve cesting (NDT) of boch coatings and claddings aust also be Improved to assure component reliabillty. In-situ coating may be important for advanced fusion machlnes. However, It is too early to clearly evaluate the prospects for successful development of this technology. 


\section{III.5.2 Heat S1nk Materials}

\section{III.5.2.1 Copper Fabrication}

The candidate copper alloys listed In Table III-4 are ali capable of belng fabrlcated to varlous degrees. Host copper alloys are readily aval1able, although they may have to be spectal ordered as many forms are not avallable directly from stock. That 1s, operatlong such as mechining, forgIng, shaplng, welding, brazing and other jolning wethods are compatible with them. All of the alloys, if in the cold vorked conditton, will be annealed by welding or hlgh-temperature brazing. Thus, the selectlon of a specific alloy Is highly dependent upon the fabrication nethods to be used.

The most likely fabrication problem for copper heat olnk waterials are how to provide internal coolant channels in the heat sink shapes, attach thet to substrates and attach low-Z tiles or coatings to them. The last two subjects will be covered In the next section. If the plate is thick enough and simple in geometry, internal coolant channels can be formed by simply drilling coolant pasoages and mantfolding them. Devices with wore complex shapce or $11 \mathrm{mited}$ thleknesc may be forced to use technlques such as brazing, diffusion bonding, electroforming of explostve bonding to close out the coolant channels. All of these jolning technlques have been used with success on copper. Hign temperature brazing ( $\left.600^{\circ} \mathrm{C}\right)$ will result in significant strength reduction in all alloys except alloys already annealed or dispersion strengthened alloys (such as $\mathrm{CuAi}_{2} \mathrm{O}_{3}$ ). The GuBe allcys are unique in that they do aot need cold work in order to develop high strength. Thus, an overaged matertal can be resolutiontzed and aged to recover its strength.

Since all the candidate alloys have high thermal conductivity, welding is difflcult because of the heat slnk effect of the surrounding materlal. Th1s ts espectally true for thicker sections. Eleckron bean weldtag is very wellsulted for welding copper as $1 \mathrm{te}$ high power density allows the welding to be done without annealing the bulk of the met:rial. Lager welding is ouiy possible $t_{n}$ the thinneat of sections hecause of the reflectivity of copper alloys. More conventional welding methods (TIG, arc, etc.) are possible but result In severely anneallng the ares around the weld. Thus, they are suitable only for annealed copper or alloys capable of being hardened without cold work, such as CuBe alloys. 
Prograns are needed in the folloning area in order to fabricate heat sinks for use in the next generation of devices:

(1) Investigation of techniques to allow welding of copper alloys with retention of a high percentage of original strength andfor to localfze softenIng region to Immediate area around weld.

(2) Development of brazing techniques for high-strength copper alloys. Investigate newer low-temperature braze alloys for uge with copper alloys. Develop technlques and guidelines to minimize overaging of cold worked structures. Examine effect of operating tedperature on braze strengths.

(3) Electrodeposition of copper provides an alternate fabrication method for heat slnks, Methods of producing high-atrength electrodeposited copper that can operate at temperatures above $250^{\circ} \mathrm{C}$ need to be lnveatigated.

When conducting any program to lovestigate fabrication of heat sink materials, close conslderation trugt be placed on methods to the used in attaching the primary thermal loading component to the heat sink. The selected foining method must be compatible with the heat sink fabrication methot.

\section{III.5.2.2 Refractory Metals}

\section{Primary Pabrication}

The combination of a bigh duct1le-to-brittle trangition temperature and resistance to deformation makes the processing of the group VIB metals ent1re1y differeat from that of the VB metals. Inftialig wh the acivent of advanced casting techniques, It was thought that arc casting could be used to conoolidate tungeten, thereby" substantially fncraasing the sizes avallable in tungaten sheet or plate over what could be produced by the powder metallurgy route. Unfortunately, the large graln size coupled with tungsten's reslatance to deforwation make initial breakdown or bloowing of the cast ingot extremely difficult because of the very high temperature needed to roll tungsten and the large $\pi 111$ geparetion forces to prevent alligatoring of the slab. For this 
reason, arc casting was abandoned for the production of sheet and plate in favor of powder netallurgical techniques. Today, virtually almost all tungaten is anufactured via the powder netallurgy process. In this process fine grain tungsten posder is elther hydraullcally (wechanical) or 1sostatically pressed fnto a blllet which 1o subsequeitly sintered in hydrogen at around $2500-2700^{\circ} \mathrm{C}$.

Intitial breakdown ts usually accompliahed at $1500^{\circ} \mathrm{C}$ olth the temperature slowly belng reduced with tncreasting cold work to prevent recrystallization which would ralse the DBTT. For fugton, the transition temperature should be $250^{\circ} \mathrm{C}$ or lower to reduce the potential for fracture during a plasma diaruptlon. For the trangition temperature to be this low wil requfie about $80 \%$ cold work. To put this nuch cois work into tungeten would require a combination of forging and rolling at falrly high temperatures whtch will llatt the welght and size of the part that can be produced. Currently the maximum size that can be produced without substantial scale-up is $50 \times 50 \mathrm{~cm}$ for a $1 \mathrm{~cm}$ thick plate and $35 \times 35 \mathrm{~cm}$ for a 2 ca thick plate. While it is technically feaslbie to produce larger parts, the increased cost and risk in increasing the transition tenperature does not appear to warrant this scale-up for parts much larger than currently avallable.

Molybdenum is processed in much the same way as tungsten, however, molybdenum and its alloys can be wrought from arc cast ingots and, consequentIy, can be made into sheet and plate roughly twice the size of tungsten sheet and plate. In obtaining sheet and plate in these two materials, there are a number of factors that 1 int these size ranglings from supplier furnace temperacure and size Ifmits to the welght of the part 1eself. Slnce tungsien 1s almost twice as dense as nolybdenum, handling of large components is difficult and this alco limito size.

The group VB refractory metals are extremely ductile and can be readily processed from efther arc cast or electron beam melted ingots. The "as cast" Ingots are then forged Into slabs or sheet bars for subsequent rolling at temperatures around $400^{\circ} \mathrm{C}$. These slabs which range in size from 5 to 10 on in thickness are than rolled on conventional rolling mills to the designed thickress. The final product is then fully annealed in a vacurum. Because of these materia1s' high duct111ty (30-50\% elongation), the large reductions per pass needed to prevent alligatoring in tungaten and rolybdenum are not required. 
The net result is that larger sheets can be produced on the same piece of equipment becaube of lower separation forces on the rolifing mill. It also means that tantalum and rifoblum can be processed on any rolling will in the country capable of rolling large stainless steel plates. Currently the maximum slze of tantalun plate avallable 18 toughly $60 \times 120 \mathrm{~cm}$ for $1 \mathrm{~cm}$ thlck plate and $60 \times 60$ for the $2 \mathrm{~cm}$ thick plate. Each of these plates weigh approximately $125 \mathrm{~kg}$. The prinary 11mtations in the size of tantalum avallable is in the plckling operation. Because of tantalum's resigtance to corrosion ( 1 t's resistant to most acids Including aqua regla), only extremely concentrated acid solutions contafning large concentration of hydro-fluorlc acld can be used. These concentrated actd solutlons complicate the procesolng of large, heavy plates with conventional hatialing equipnent. Since Ingots welghling up to $2000 \mathrm{~kg}$ can be cagt and forged into slabs, the procesaing of larger plates is technically feasible except it w1l require capital expenditure for additional equipment to procese the larger plates. However, in producing the larger plates, there will be a cost Increase over current plate costs. The same limitations that apply to tartalum alloys are also valid for niobtum slloys.

\section{Secondary Fabrtcation}

The refractory metals have been successfully fabrtcated in a number of complex stiapes. However, the bulk of the fabrication has been on relatively thin structures ( $<2 \mathrm{~mm})$; very little work has been done on thicker structures. The most extensive fabrication of heavy gage $(>1 \mathrm{~cm})$ has been done on No-12x in the early 1960's. In this processing, the same equipment and technigues used for high strength seels were applied to the Nb-12x. In fabricating tantalum and nioblum alloys today, the same techntques would be used. For tungsten and molybdenum, the processing will be at temperatures approaching those used in primary fabrication.

Satiffactory braze joints have been obtalned in both molybdenum and tung sten using vacuum and Inert atmosphere furnaces. The bulk of the brazes developed have been for high temperature applications $\left(1000^{\circ} \mathrm{C}\right.$ ) and 11ttle Information is avallable for low temperature brazes. In high temperature brazing, care has to be exercised not to recrystallize the tungoten or molybdenum which will result in an embrittled structure. There appears to be a 
unfform lack of property data on braze joints ade with rertactory metals, and those that do exist are for short tera tests. The bulk of brazing work to date has been for refractory mecals folned to refractory metals, however, there is sole infotwatiou uvallable regarding brazing of molybdenum.

Investigators have trted for number of years to develop techniques to weld tungaten and molybdenum. In all cages even though succesaful velds have been ude, they uoually crack because of residual stresges. The only successful welds have been those mede Fich a cungeten-rhenim or molybdenum-rhentum alloy. Because of the difficulty in welding tungeten and molybdenum and the brittle nature of thelr welds, chls approach is not feastble.

Tantalum and nfobfum are veldable and a number of large structures have been fabricated using a varfety of techniques. The primaty concern is the contanination by lnterstitials. To prevent contamination, welding lo ugualiy performed elther in an Inert atmoophere or vacuum chamber. In Ingtances where the structure is too large to be fitted into a chanber or bubble, ductile welds have been abtalned in air by flooding the weld zone with an lnert gas and using a trailing shield to protect the weld zone during cool down. For welding sheet thicknesses up to $1.5 \mathrm{~mm}$, post weld otress relleving is usually needed to minfmize diatortion. While tantalum can be readily welded to 1tself, trelding $1 t$ to other metals, with the exception of nioblum and vanadium alloys, has been largely unsuccessful. There axe a vartety of reasorts for this but the two primary ones are that the melting point of tantalum is usually above the bolling polint of the metal it's to be welded to or that the resultant folnt comtaing brittle tinteratallic compounds or formo low meiting eutectlcs.

\section{III.5.3 Attachment}

The root promising techniques for jolning dlssintlar materials for hlgh heat flux components are brazlng, diffusion bonding, coating, Inorganic bonding agents and mechanical attachments. The following discussion sumbartzes the state of knowledge of respect to the varlous attachment techntques mentioned.

Brazing techniques have been widely used to form both metal-metel and ceramic-metal joints. Brazing offers a great deal of promise for the fabrication of high flux components since a wide varlety of commerclal brazes are 
avallable and technlques for theit use have been established. However, very ittie experience has been gained in the fabrication of the particular materials conbinations needed for high heat flux components. Thus, considerable effort w11 be required to eatablish the optimum material combinations, geonetry, braze alloy selection, jolnt design and brazing cycle that will perform successfuliy under fusion reactor condittons. Almost no date base 18 avallable on testing of brazed high heat comonents to perait any predictions of Interface performance under fuston reactor conditions. Stnce brazing offers a great deal of flexibility in the cholce of different materlala combinations, it should be given a high priorlty for further evaluation. However, brazing is not a preferred method for materials combinations where one of the waterials is wuch thinner than the other, as in a thin coating. Brazing nay also be difflcult where complex contours are required. Scale-up may also be a major problem. Brazing approaches should be considered for both near tern and far term gachines.

Diffusion bonding like brazing has been used for both metal-metal and ceramic-metal folning. Diffusion bonding requires simultaneous applfcation of both presaure and heat during the bonding process. Thus, diffuston bonding is often more expensive than brazing and there are practical limitations on the size and geometry of the surfaces to be jolned. Diffualon bonding can produce very high quality folnts, and maximun service temperatures are of ten higher for diffusion bonds than for comparable brazed folncs. In some cases, process tenperatares for diffusion bonding are lower than brazing temperatures for a comparable joint. This is particularly attractive for attachment to copper alloy heat sink material that may develop undesirable microstructures at typical brazing temperatures. At present little is known about diffuston boading of potentialiy interesting ceramic-metal folnts. A major problem fur both diffusion bonding and brazing of ceramica to metals is the typically large misnatch in the thermal expansion. The database for metal-metal diffusion bonding 18 sosewhat better, but it is btill very lintted compared to the data avallable for metal-metal brazing.

Although mechanical attachmente for high heat flux components are attractive from the standpint of servicablity and ease of replacement, serious questions remain about their ability to handle the high heat loads anticipated In a fusion reactor; thus, it is not anticlpated that mechanfeally attached 
schemes will find wdeapread application for high hest flux components. However, mechanteal attachnent schenes way be considered for near term wachines or for those components which recelve the lorest heat $10 \mathrm{al}$.

A lower level effort should be expended to Identify and evaluate some promising inorganic adhesives for Interface attachnents such as metal or glasay based bondlig agents, which cure at relatively low temperatures. Such adhesives would offer the advantage of ease of application over large and complex ourface areas and low fabrication temperatures. They may suffer the disadvantage of not heving adequate bond strengtha for this application. Inorgantc adhesives could be developed for near term machines and then evaluated further for advanced mach1nes.

\section{III.6 Other Issues - Tritium Permeat Ion}

Tritium permeation through first walls, 1imiters, or divertors subjected to energetic tritium charge exchange neutral borbardment is a potentially serlous problem area for advanced D-T reactors operating at elevated temperatures. H1gh concentrations of trittum in the near surface region can be reached by implantation of the charge exchange neutral flux combined with a relatively slow recombination of these atons into molecules at the plasma/ first wall interface. Because of this large concentration of moblle tritium near the Inner (plasma) wall surface, a concentration gradient lo established, causing tritium to diffuse into the bulk and eventually to the outer wall gurface where it can enter the firat wall coolent. Calculations have shown that the cholce of Inapproprlate materials (e.g. $\checkmark$ for the MARS direct convertor) could lead to tritium permeation as large as $10^{8} \mathrm{Cl} / \mathrm{day}$.

Current modeling of trittim permeation is perfortied by numerical solution of Fick's Law including a tritium oource serm and recombination boundary conditions. The model has been teated extensively and gives gaod agreement with laboratory experiments. Central to the model is the recombination constant. A simple formala $1 \mathrm{~s}$ used to estimate this constant from a combination of bulk properties (diffusivity and solubility) and surface condition. This formula has been verified experimentally for austenttic stalnless steels, 1ron, Inconel, nickel, vanadium, and titanfum. Vartation of surface conditions has been shown to affect permeation in a predictable manner. 
Two types of experinental date for high heat flux naterials is needed. Firot, for many aterials such as TIC, graphite, etc., the bydrogen solubility and diffusiotty ls $_{\mathrm{s}}$ not well known. Rnowledge of these propertles makes it possible to obtain a prelininary estimate of tritiun permeation. Second, for those materials of serlous Interest, a direct measurement of recombination constant is needed. Since this constant depends scrongly on both temperature and surface conditions, a measurement with conditions appropriate for machine operation must be obtalned. These measurements are currencly being made by measuring recycilng in operating rachlnes. Jnfortunately this procedure has the disadvantage of having to bulld the machine before the tritium permeation problem has been addressed. Alternatively, the measurements can be taken In a plasia-driven perweation apparatus. This teshnfque has the disadvantsge of trying to simulate machine-relevart surface conditions.

The above discusston applies to materlals in which hydrogen transport 13 by atoms. For matertals such $\mathrm{s}$ glasses, oxides, etc. In whtch the tranpsort process occurs through molecules, the above arguments are signfficantly modifled. No modeling (or experiments) for buch materials is currently avallable. If such materiale are proposed for high heat flux application, an extenBive experimental effort would be required to determine the underlying processes that control plasma-driven permeation.

\title{
III.7 Materials and Prucesses Technolcgy Needs
}

The matertals and processes data base assessment indicates that Information ls needed in several areas. The development areas can be divided as shown below.

\author{
Baselfne Property Data \\ Thermophysical \\ Mechanical \\ Corrosion \\ Surface \\ Fabricailon Technology \\ Primary Fabrication \\ Secondary Fabrication \\ Bonding
}




\section{Irrad1ac1on Damage Effects \\ Therwophysical Properties \\ Mechanfcal Propercies \\ Bond Integrity}

Each major area applies to the plasma st.je materlals, heat sink materiala, and bonds.

Baseline rxperitental data providea loportant Inforagtion concerning the potent1al operating 1 tmitis of different materia ${ }^{+} s$. This information is required as Input to design stuaies and analysis which w11 in part determine the optimum configuretiun for high heat flux cowponents. The anount of information needed to sompletely charycterize a materfal 1 . extensive, and the materfals described in thls section are all lacking in some important data. The root 1 portant properties for ligh heat flux components are thermophysical, nechanical, currosion, and surface properties. Thermophysical propertles include thermal conductivity, tharroa expansion, elastic modulus, and spectfic heat. The primary variables are temperature and fabrication proceture, The mechanical propertles include tensile propertles (ultimate strength, yleld str ngth, total elongation, uniform elongation), fatigue, crack growth, thermal creep, and creep-tatigue Interactions. The primary varfablea are temperat ure, stress, Btrain rate, and fabrication procedure. The corrosion areas include coolant corrosion, stress corrostor. cracking, and compatiblity between different materials. The important vardahleg are temperature, stregs, coolant chemistry, materfal composition, and fabrication procedure. The surface propertles Include sputtering (D, T, He, self), partlcle Implantation eftects (D, $T$, He), surface structural properties following sputtering, surface chemlstry (Btolchlometry changes, eurface segregation), and propteties of redeposited materials. The Important varlables are particle bombar jment enersy, particle flux, and material temperature. The aurface data basc assessuent is covered in detall by the PMI task group data base assessment and will not bu considered any further in thts sectlon. It lo clear that the large number of properties to be studied combined with the list of candidate materials results in a pote-tlally extenglve test matrix. 
Fabrication technology data provides infornation to the designer about the proctical 11nits for the manufacture of high heat flux componenta. The najor areas of fabrication technology are primary fabrication, Becondary fabrication, and bonding. Primary fabrication consists of the processes involved in transforming raw materials into consolldated forms, such as ingots, billets, plates or sheets. Secondary fabrication constets of trangforming the products of primary fabrication Into finished products. These processes Include machining and forming. Bonding processes include trelding, brazing, diffugion bonding, etc. of cen the materials properties are highly dependent upon the fabrication processes. Therefore, it is 1nportant to teat materials In the fort in which they are 11kely to be used in the fusion reactor.

Irradlation damage will degrade the baseline materlal propertleg and will be an important consideration for high fluence devices. It is generally desirable to study the effects of radiation on all the properties mentioned above for a range of fluences and 1rradiation temperatures. In addition, mlcrostructural development during 1rradiation (swelling, dislocation structure, preclpltation), w111 need to be Invegtigated. The potentially large number of tests along with the high costs and long lead times of Irradiation experinents means that careful planning to a necessity.

The research and development neegs for materials and processes vary with the time frame of the fusion device. In the remainder of this section the development needs and critical losues will be Identifled for the different fuston soncepts.

In present devices, the material developoent needs are mintmal. Recently work has begun on the design and fabrication of berglifum 1imiters for ISX, and potentially, beryll1ur 11miters w11 be Inatalled in JET. Thus, the new development required for present machines 18 for the fabrication and use of beryllium. There is considerable experience in the fabrication of beryllium components, so that no major developrient programg are anticlpated.

In near term devices and ignition devices, there are major developmenc needs. Both tokamaks and mirrors will employ large, actively cooled, hIgh heat flux components that are exposed to the plasma. The primarv goals of the development are the selection of the reference plasma side and heat sink materials and the identiffcation of the most appropriate fabrication proce dures. In order to reach these goalo, major programs are needed to obtain baseline property data and fabrication data. 
The chotce of a reference plasan side material will depend on the aurface and bulk properties along with the device operating conditione. At the pregent time, low-Z materials are preferred for vee in tokamaks. The candidate naterials are $\mathrm{Be}, \mathrm{C}, \mathrm{BCO}$, and $\mathrm{SIC}$, and there are critical lasues essoctated with each material. Graphlte has man destrable properties, but it 18 expected to interact chemically with the hydrogen plasma. The critical lssue for graphlte 18 whether aputtering eroalon enhanced by the chewical interactions can be tolerated by the tokanak plasma. A related lsgue to the redeposition of spittered material. It is nat clear that redeposited graphite will be adherent or whether it w11l exhlbit Bat1sfactory bulk propertlea. Both of these issues need to be exanined before graphlte can be considered to be a viable plasma side matertal. It should also be mentioned that small additions of other materlals, 11ke S1C, to graphite nay alleviate the chemfcal sputterIng problem, and such graphite "alloyl" ghould also be tested. Beryllium is not expected to exhiblt chemical sputtering, and thus it appears to be a Eat lsfactory matertal for normal operation. However, there 18 concem about the use of beryllium curing disruptions. Beryllium, being a relatively 10w meiting point and high thermal conductivity materia1, may form a thick melt layer during disruptions. The major tasue for beryllium is the potential rapid loss of material due to the formation and $108 \mathrm{~s}$ of the melt layer. SiC and Be0 are refractory compounds. A major 1ssue for compounds is whether sputterlag occurs preferentially for the individual elements. Preferentiai sputtering would lead to a change in the surface composition and poselbly to a change in the surface propertles. All of these surface related 1ssues are coverad in greater detall in the PMI technlcal assesament, (4) but they are mentioned here because they are critically important to the selection of a plasma side meterial. Baseline data ls also needed to describe the bulk properties of plasma slde material. The non-metals, $C, B e 0$, and SiC, require special attention because their properties can vary significantly depenaing upon the fabrication procedure. Both the thermophysical properties and the mechanical propertles need to be measured over a range of temperatures and stresseg.

The heat ank waterial in neal term devices is moet llkely to be a high thermal conductivity copper alloy. However, a reference alloy has not yet been selected, because in wany cases, the basellne date base ls 1nadequate. Thermophyatcal and aechantcal properties should be measured for a varlety of 
alloys over a range of temperature atrens, and strain rate conditions. If no comerctal alloy provides all of the required propertles, then developaent of a new alloy ung be needed.

An Integral part of the development for near terw devices lo the fabrication of high heat flux components. The fabrication of separate materials is generally well developed, but the fabrication of structure incorporating both plasma side and heat sink materlals requires development. The key isgue related to fabrication is whether metallurgical bonds between plasma side und heat slnk materials can be successfully and consibtently produced. A related 1ssue is whether the bond can be fabricated without advergely affecting the bulk properties of the heat sink. Several copper alloys gain much of the strength by cold working, and the temperatures needed for bonding may anneal the atructure and reduce the strength. Because bonda are developed for opecifis meterials and applications, a different bonding technique meg be required for every plasma side material.

In general, materials and processes needed for mirrors wil be the same as those used in tokamaks. Besldes the materials already mentioned, hfir, $-\mathrm{Z}$ matertals such as molybdenum and tantalum are being considered as both plasma s1de and atructural mater1als. Work will be needed in the areas of mechanical property evaluation and fabrication development for these materials.

High heat flux components in reactor prototyplcal devices will be subjected to moderate to high neutron fluences. The critical lobue for this class of devices is whether these components can maintain acceptable propertles following 1rradiation. The additional requirement of radiation damage resiatance may have a significant impact on the cholce of materials. For example, non-metal candidates for plasma side materials, such as $\mathrm{C}, \mathrm{SIC}$, and Be0, way be ellminated because of rapid degradation of the therasl conductivity with radiation damage. The selection of heat olak mate:ial may also be affected if radiation embrittlement and owelling are significant. A major research program will be needed to examine radiation damage lesues for the candidate materisls and bonds. Thertophysical properties, mechanical propertles, and radiation swelling and creap should be measured over a range of cemperatures and fluences.

Reactor prototypical devices may also utilize refractory metals, ouch as vanadium, nloblum, or tantalum, in high heat flux components. The data base 
for these metals, at the expectei operating conditions, 1e ouall, and thus a broad based progran is needed to develop thea for use in fusion reactors. Baseline property data is needed in several areas including mechanical prop.rthes and conlant corrosion. Pabrication developnent is required to show that thege materials can be anufactured in the full gize components. Finally, Irradiation danage studies are needed to determine if these materials can suxvive the neutron environment. 
1. M. Abdou, et al., "Impurity Control and Firat-Wall Englneering", Chapter VII In USA Contribution to the INTOR Phase-Two-A Workshop, FED-INTOR/B2-1, Georgia Institute of Technology (1982).

2. A. L. Werd, R. N. Johngon, G. L. Guthrie, and R. C. Aungat, "Irradiation Effects on Low Friction Coatings for LMPBR Applications," HEDL-TME 75-108, November 1975.

3. R. N. Johnson, et al., "Development of Low Friction Mater1als for LMFBR Components," Proceedings International Conference on ilquid Hatal Technology In Energy Production, CoNP-760503-P1, May 1976.

4. R. W. Conn, et al., "Technical Assessinent of the Critical Issues and Problem Areas in the Plasma Materlals Interaction Field," UCLA, PPG-765 (1984). 


\section{CHAPTER III}

MATERIALS AND PROCESSES

Lead Author:

R. F. Mattag (ANL)

Cont r1 butors:

M. I. Baskes (SNL)

J. W. Dav1s (MDAC)

R. N. Johnson (HEDL)

P. Mloduszewok1 (ORNL)

E. K. Opperme I 'HEDL)

S. N. Rogenorager (INESCO)

H. F. Smith (SNL)

R. D. Stevenion (INEsCo)

A. Tobin (Grumnan)

P. F. Tcrtare111 (ORNL)

F. W. Wiffen (ORNL)

W. Wolfer (UW) 
CHAPTER IV

THERMAL HYDRAULICS

Lead Author:

R. D. Boyd (SNLA)

Contributors :

c. P. C. Hong (GA)

Y. S. Cha (ANL)

*A $_{A}$ portion of this work was performed et Sandia National Laboratories supported by the U.S. Department of Energy under contract number DE-AC-04-76DP00789. 
IV. TECHNICAL ASSESSMENT OF THERMAL-HYDRALLTC TECHNIQUUES FOR HIGH HEAT FLUX FUSION APPLICATIONS

\section{IV.1 Introduction}

Th1s chapter is a technical ageesswent of three possible thermalhydraulic, bigh heat flux removal techniques which will result in adequate heat removal with minimum penalty from components in fusion reactors. The heat removal alternatives discussed are: (1) subcooled flow bolling (SFB) with water, (2) high veloctty hellum gas convection, and (3) liquid metal heat transfer in the presence of a magnetic fleld. The assessment enphasizes advantages, disadvantages, avallable data base, and applicabllity of fuston component requirements. The reader is referred to Ref. 1 , which is an expanded version of this technical assessment, for additional detalls.

Because of the relatively high heat flux levels and Icng pulse duration in the next generation of fusion reactors, in-veosel components must be actively cooled. Table I of Ref. 1 contalins a partial list of fusion devices (planned or under construction), spectfic fuston components to be cooled, and anticlpated mean and peak steady-state heat-flux loads. All fusion components will be heated nonuntformly over their surface and the surface area of most components vary from $0.1 \mathrm{~m}^{2}$ to $100.0 \mathrm{~m}^{2}$. Most componencs will be subjected to steady-state heat fluxes ranging from $0.005 \mathrm{kH} / \mathrm{cm}^{2}$ up to $1.0 \mathrm{kH} / \mathrm{cm}^{2}$. Only the heat flux of the first wall for compact fuston reactors, beam dumps, and armor olates will exceed these leve1s.

\section{2 Three High Heat Flux Heat Removal Techniques}

In order to provide a common basis for comparison, computacions are made for each high heat flux (HHF) removal technique for a speciflc case study of cooling 2 uniformly heated coolant channel, $1.5 \mathrm{~m}$ long with an Instde diameter of $1.0 \mathrm{~cm}$, subjected to an external uniform heat flux (q) of $0.5 \mathrm{kH} / \mathrm{cm}^{2}$. Although in practice the heat flux will be nonuniform, a uniform flux is useful for comparative purposes. The solected heat flux level is relevant to many of the exiating and future fusion machines (e.g., TFTR, TEXTOR, D-IIT, IFCX, etc.). 
It shnuld be noted that the geonetry chosen may not be optialzed for each heat removal technique. There are many coupled design congtrainta (e.g.; materfal selection, thermal stresses, coolant leakage, safety, tritiun control, and plasma edge heat flux profile) which must be incorporated before a specific dealgn can be coupleted.

\section{IV.2.1 Subcooled Flow Bolling (SFB) with Hater}

Subcooled flow bolling $1 \mathrm{~s}$ one of the most effictent techntques of transferring high heat fluxes. As an incressing thermal heat flux is appilied to the walls of a coolant channel containing a flowing aubcooled fluid (1.e., the fluld's bulk tepperature, $T_{f}$, is always below the aaturation temperature, $r_{2, a t}{ }^{3}$, the heat transfer capability increases with an accompenying rise in the wall temperature. The cooling fluid changes from a singlephase condition to a two-phase liquid/vapor regime up to a point in the SFB regine where a maximum or "critical" heat transfer rate is achieid. This maximum heat flux is referred to as the critical heat flux (CHF) and, if exceeded by the applied heat flux, will result in a significant drop in the rate of heat transfer to the flowing fluid, a precipitous rise in the heated wall temperature, and possible destruction of the coolant channel. Since the CHF forms a practical upper limit for the 1mposed heat flux in flow boiling, eraphasis is placed on CHF, its characterization, prediction, enhancement, and aval lable data base.

Substantial progress has been made in undergtanding some mechanions and the multiple-parameter dependence of SFB CHF(1). However, in considering the requirements for fuston reactor components, the SFB data base is trcomplete. CHF data exists over portions of the following range of parameters (see Tabie III of Ref. 1): (1) CHF ranging from $0.013-32.0 \mathrm{kw} / \mathrm{cm}^{2}$, (2) coolant channel heated length to dlameter ratso, $L / D$, ranging from 4.8 to 790., (3) mess velocity, $G$, ranging from $0.068-90 \mathrm{Mg} / \mathrm{n}^{2} 8$, (4) water velocity ranging from $0.07-95.0 \mathrm{~m} / \mathrm{s}$, (5) pressure, p, ranging from $0.1-78.5 \mathrm{MPa},(6)$ flow channe1 hydraulic dlameter, D, ranging from 0.4-19.0 $\mathrm{mm}$, (7) binary mixtures, and (B) many different geometries and thermal loading configurat1ons. However, there are large gaps In the Ebove parameter ranges and the data accuracy can vary from about $\pm 5 \%$ to as high as $\pm 40 \%$. In addition to the above expertwental data parameter ranges, a large number of flowbofling CHF correlation parameter ranges can be found in Ref. 1. 
Fundamental questions which wat be addressed with respect to future fuston componencs include: What are the lints of $L / D$ for which the SFB regime can be maintained over the entire length of the coolant channe1s; and, In addition to increasing the exit pressure, mass veloctey, and subcoolIng, how else can these limits of $L / D$ be increased?

The SFB case study was conducted for an inlec temperature $\left(T_{1 n}\right)$ of $20^{\circ} \mathrm{C}$ and an exit pressure $\left(p_{e x}\right)$ of $1.55 \mathrm{MPa}$. The result $\mathrm{s}$ are shown in F1g. IV-1. Raged on the coolant's exit bulk fluld temperature, $\left(T_{f_{e x t t}}\right)$, subcooled nucleate bofling occurs within the channel when mass velocfity $(G)$ $<8.2 \mathrm{Mg} / \mathrm{m}^{2} \mathrm{~s}$. The onset of nucleate bolling (ONB) occurs at ar exIt wall temperature $\left(T_{w}\right)$ of $207^{\circ} \mathrm{C}$ and fully developed subcooled boiling occurs at a wall temperature of $236^{\circ} \mathrm{C}$. Therefore, partial nucleate bolling sccurs between these two temperatures and beging at the exit for mass velocities between 8.2 and $8.8 \mathrm{Mg} / \mathrm{m}^{2} \mathrm{~g}$. Fully developed bolling (FDB) heat transfer Is approximately five times the single-phase heat transfer; this will result in approximately a factor of two increase in the heat tranefer coefficient computed using single-phase equations $\left(1 . e ., h_{\mathrm{FDB}}=118 . \mathrm{kW} / \mathrm{m}^{2} \mathrm{~K}\right.$ for $\left.\mathrm{G} \leqslant 7.0 \mathrm{mg} / \mathrm{m}^{2} \mathrm{~s}\right)(1)$. The bubble boundary layer $1 \mathrm{~s}$ assumed to di-ach at the exit where the bulk fluld temperature curve intersects the curve for fluid temperature required for bubble detachment $\left(T_{f_{d}}\right)$.

Four CHF correlations by Gambill, Bowring, Katto, and Macbeth were used to determine the variation of CHF with $G$ (see Fig. 3 of Ref. 1). Based on Bowring's correlation, the mass velocity must be greacer than $6.6 \mathrm{Mg} / \mathrm{m}^{2} \mathrm{~s}$ to avoid $\mathrm{CHF}$. For a ratio of $\mathrm{CHF} / \mathrm{q}$ of $1.5, *$ the required value of $\mathrm{G}$ is about $12.5 \mathrm{Mg} / \mathrm{m}^{2} \mathrm{~s}$. Smaller values of $\mathrm{G}$ are possible, depending on the heat flux distribution, the heat transfer enhancements used, flow chapnel geometry, channel materials, and thermal stress 11mitations. The pumping power (P) per channel is about $0.16 \mathrm{~kW}$ and $0.6 \mathrm{~kW}$ for $G=8.0 \mathrm{Mg} / \mathrm{m}^{2} \mathrm{~g}$ and $12.0 \mathrm{Kg} / \mathrm{m}^{2} \mathrm{~s}$, respectively. In these cases, the pressure-drok $\left(\triangle \mathrm{PSCB}_{\mathrm{SC}}\right)_{\mathrm{B}}$ $0.23 \mathrm{MPa}$ and $0.62 \mathrm{MPa}$, respectively. If precise values of the wall superheat are needed in a design, the local pressure drop must be used to compute the local varlation in the saturation temperature.

*The ratio, CEF/q, is systen-dependent and is coupled to thermal-hpdraulic and other design constraints. 


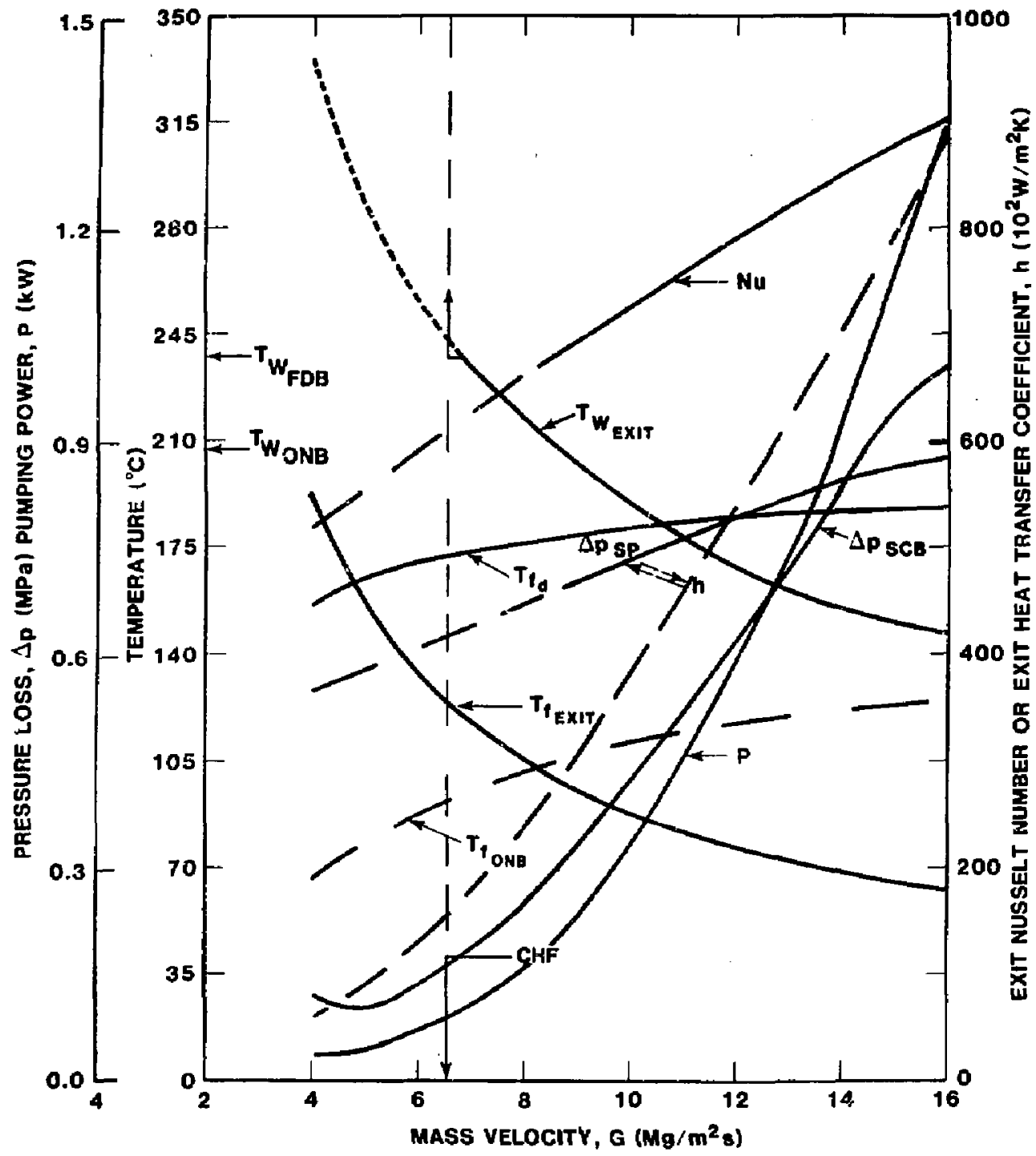

F1g. IV-1: Predictions of the Exit Conditions (Wall and Bulk Fluid Temperatures, Nusse1t Number and Heat Transfer Coefficlent), Pressure Drop (Single-Phase, $\Delta \mathrm{P}_{\mathrm{gp}}$, and Subcooled Bolling, $\Delta \mathrm{PSB}$ and Pumping Power, P, as a Function of Masa Velocity (G) for a $1.5 \mathrm{~m}$ Long, $1.0 \mathrm{~cm}$ Dianeter (Inside) Tube Subjected to a Uniforn Heat Flux of $0.5 \mathrm{~kW} / \mathrm{cn}^{2}$ and Cooled by Subcooled Water with an ExIt Pressure of $1.55 \mathrm{MPa}$, and inlet subcooling or $180 \mathrm{~K}$. $\mathrm{T}_{\mathrm{W}_{\mathrm{FDB}}}$ and $\mathrm{T}_{\mathrm{W}_{\mathrm{ONB}}}$ are Wall Temperatures at Which Fully veveloped and the Onset of Nucleate Bolling Begins. 
The advantages and dipadvantages of SFB heat removal from tHF fugion camponents are:

\section{Advantages:}

- There 18 an egtablished SPB literature and substantial data base(1).

- Relatively low pressure loses and pumpirg power result with SFB compared to high velocity helium gas and liquid metal cooling.

- SFB results in low operating surface temperature of fusion components.

- SPB results in high heat trangfer.

- SFB heat transfer is increased by electric fields produced by the plaswa.

- There are many SFB heat trangfer enhancement options(1).

- There are no effects of magnetic field on the SPB pressure drop. Disadvantages

- Possible occurrence of CHF. However, a significant SFB data base extatg(1).

- Cleanup, in case of leakage, is a problen for any liquid (water or 11quid metal). However, water clean-up is more stralght-forward than, e.g., liquid metal or molten balts.

- Difficulty in tritium cleanup compared to hellum and liquid metal coolants.

- SFB with water in HHF components may not be cotapatible with liquid metals used in the blanket or first wall regions. This ralses a safety 1ssue (see Chapter II) which must be addressed.

\section{IV.2.2 High Veloctty Hellum Gas Convection}

High veloctty helium gas has been used extensively in the cooling of nuclear reactors. Since the first commerctal gas-cooled reactor began operating In 1956 in the United KIngdom, 40 gas-cooled reactors operating In $B$ countries have generated about a third of the world's nuclear power. However, most of the experience has been with annular geometries and addtional work $1 \mathrm{~s}$ needed for tubular-type channels. Bellum is a chemically inert, single-phase gaseous flutd. The thermodynamic and transport properties of hellum coolant are known for a wide range of temperature and pressure(1). 
Hellun is one of the bes: heat-transfer medis awong the gaseous materials. It has been used extensively as the coolant in reactors due to its low neutron absorption and low chentcal activity. In comerelal reactors, helium's heat transfer capability is Improved by neans of extended heat transfer surfaces (Magnox reactors) or by roughening the surface of the fuel element.

The performance of a snooth and a roughened tube was evaluated for the helium case study. The conditions used include an injet helium tewperature of $40^{\circ} \mathrm{C}$ and an inlet pressure of $5.0 \mathrm{MPa}$. The reaults are given in PIg. IV-2. As Indicated, at a maes flow rate of $150 \mathrm{gmis}$ and whout roughening, the maximum tube wall tempezature $18320^{\circ} \mathrm{C}$ and the coolant Mach number Is 0.32 . The cotresponding pressure drop $180.13 \mathrm{MPa}$. With 3-D roughening, the wall temperature can be reduced to $230^{\circ} \mathrm{C}$, but the pressure drop becomes very high ( $3.4 \mathrm{MPa}$ ). Although the 3-D roughening can be very effective in increasing heat transfer, it 15 also very costly due to increases in pumping power. It should be noted that the increase in heat transfer results in an increase in the helium gas temperature. Since at constant pressure the Mach number is directly related to the product of the mass flow rate and the square root of the gas tenperature, this increase In the temperature results In substantial differences in the values of Mach number for the smooth and roughened channels. The tube gize, coolant pressure, and wall roughnegs should be optimized together for given fusion component requirements.

The advantages and disadvantages of high velocity hellum gas heat removal from HHF fusion components are:

Advantages

- Hellum is chemlcally Inert.

- In case of leakage, vacuum chamber cleanup 1s easy.

- Tritiun can be extracted from hellum by standard, developed hellum purification systems.

- Helfum $1 s$ non-reactive and can be used with any blanket coolant.

- Hellum is nonmagnetic and not electrically conductive. Disadvantages

- To reduce pressure drop, the coolunt has to bo operated at high pressures, typically from 5.0 to $10.0 \mathrm{MPa}$. 


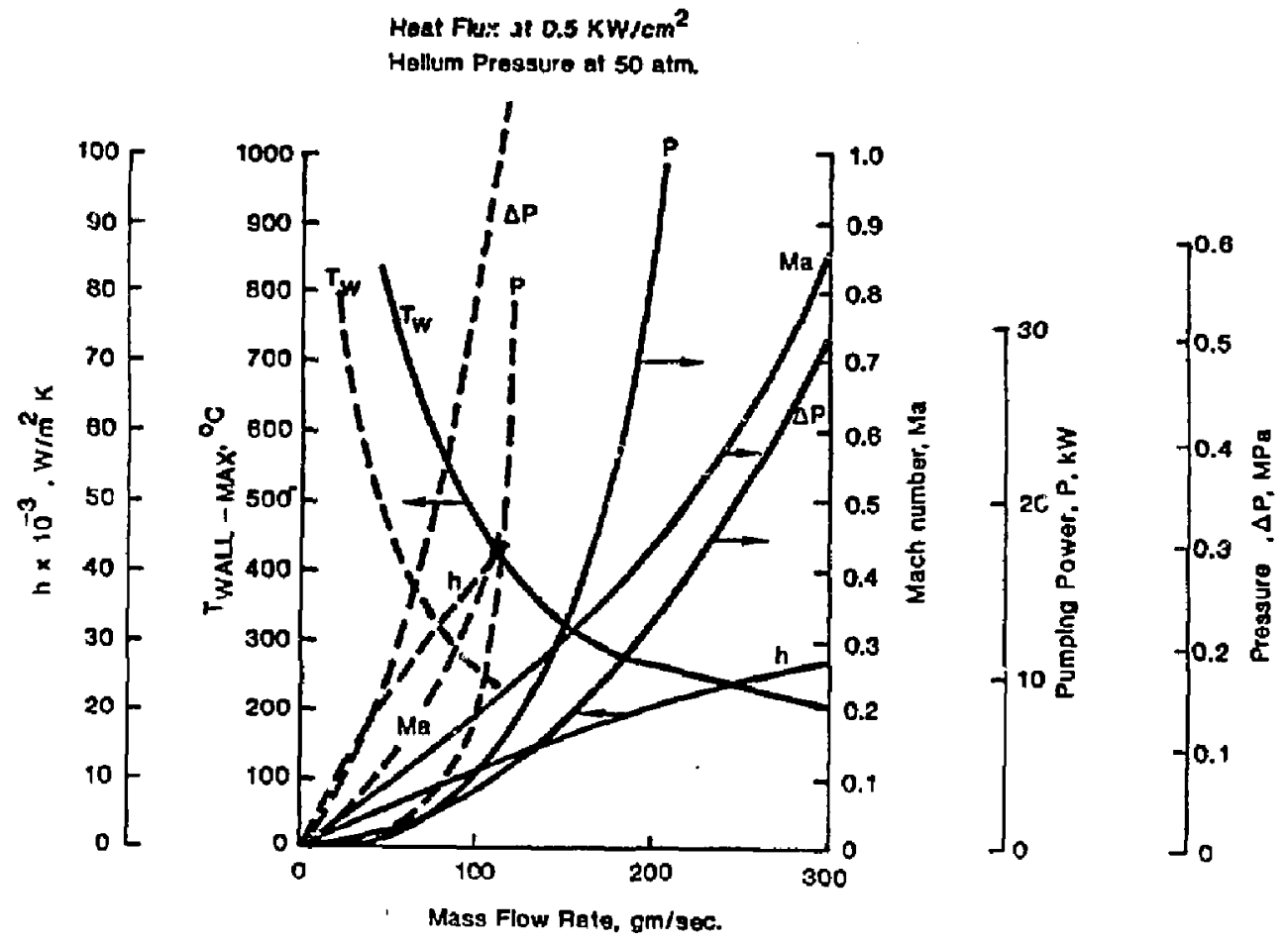

F1g. IV-2: Predictions of the Exit Conditions (Wall Temperature, Heat Trangfer Coefficient and Total Pressure Drop), as a Function of Mase. Flow Rate, for a $1.5 \mathrm{~m}$ Long, $1.0 \mathrm{~cm}$ Diameter (Inglde) Tube Subjected to a Uniforn Heat F1ux of $0.5 \mathrm{kH} / \mathrm{cm}^{2}$ and Cooled by High Velocity Helium Gas at 5. MPa (Solid Line for Smooth Well and Datted Line for Roughened Wall). 
- The higher operating pressure may result in thicker channel walla and posstble thermal stress problems.

- Punping power of helfum gas 18 much higher than that of SFB.

IV.2.3 Liquid Metal Heat Transfer (in the Presence of a Transverse Magnetic Fleld)

It is known, in general, that liquid metals are good heat transfer fluids. However, in a fusion reactor environment, a large magnetic fleld is always present and interacts with the liquid-metal (electrically conducting) flow. The thermal and hydraulic behavior of Ilquid metal flow: in the presence of a wagnetic fleld are quite different from that of a ilquid-metal flow in the absence of a wagnetic field. The relatively large amount of data and literature which deal with liquid metal heat transfer in the absence of a transve:se magneite fleld are not directly relevant for fusion components such as the first wall, the blanket, and the limtter/divertor. The discussion here will be focused on the effect of a transverse magnetic field on 1iquid-metal heat transfer and related subjects. It should also be pointed out that compatibility (corrosion) between liquid metal and structural material as well as the structural temperature limit in a radiation environment usually restricts the maximun operating temperature of the liquid metal to well below its boiling point. Thus, fusion components are not Iikely to operate in the bolling regime under normal conditions.

Three aspects of 11quid metal flow $1 \mathrm{n}$ a transverse magnetic fleld will be considered briefly before the case study is summarized. First, the pressuredrop of a liquid metal in the presence of a magnetic fleld is primarily due to the Lcrentz force and results in a pressure drop more than an order of magnitude larger than that in the absence of the transyerse magnetic field. Hence, large inlet pressures ( $75 \mathrm{MPa}$ as $\mathrm{m} / \mathrm{s}$ ) are required compared to hellun gas convection or SFB. Therefore, as a result of the large pressuredrop, large puaplng power is required. Finally, there are competing heat transfer effects. Por example, at high Hartmann numbers, the heat transfer is Increased, as is manffested by a thinner boundary layer. However, a magnetic fielc suppresses turbulence and thus reduces the heat transfer. In addition, nonuniformities in the magnetic flux density, coolant channel wall thfckness or channel shape would induce simflar nonuniformities in the velocity profile. Other effects which complicate the heat transfer are sumarIzed in Ref. 1. 


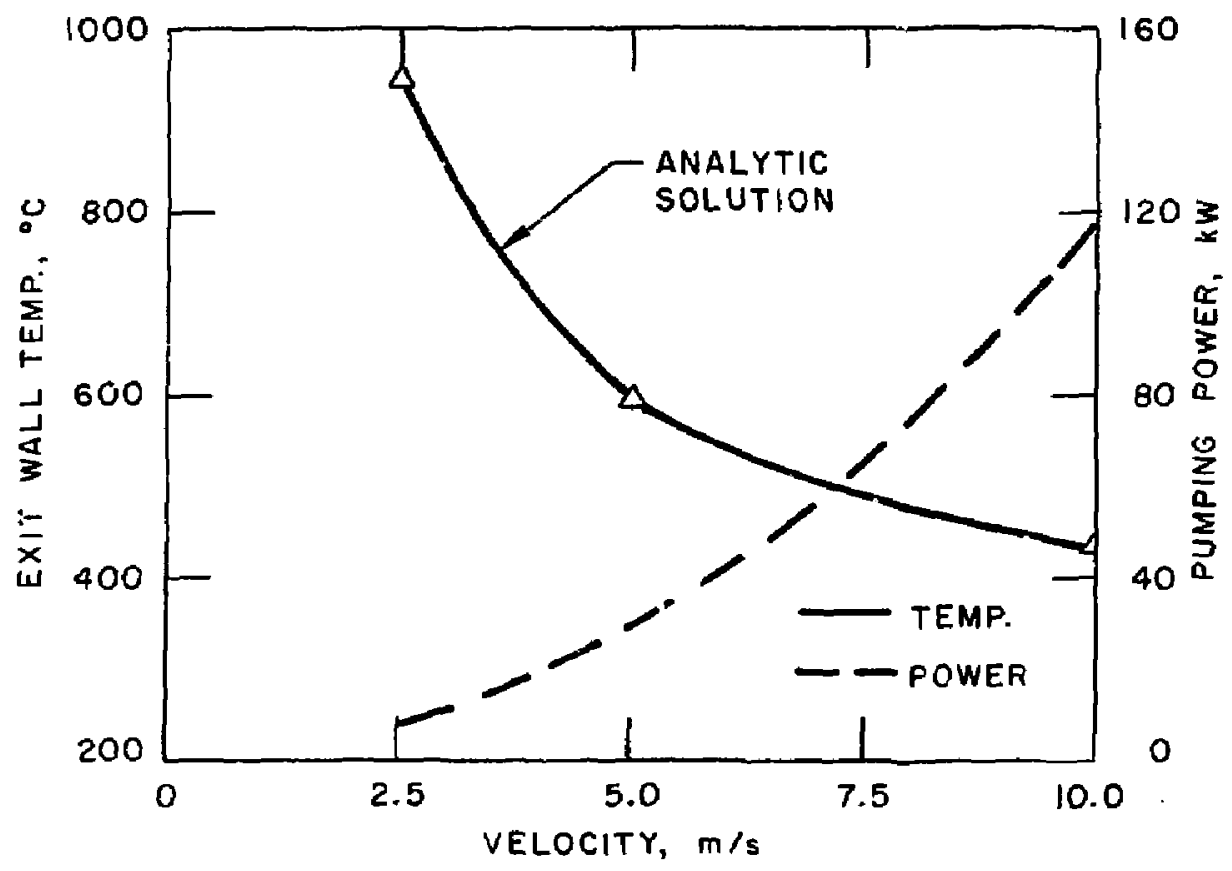

F1g. IV-3: Predictions of the Pumping Power and the Exit Hall Temperature, as a Function of Velocity, for a 1.5 w Long, 1.0 cm Diameter (Inside) Tube (Stainless Steel with $2.0 \mathrm{~mm}$ Wall Thickness) Subjected to a Uniform Heat Plux of $0.5 \mathrm{~kW} / \mathrm{cm}^{2}$ and Cooled by Liquid Ltthium, in the Presence of a 5.0 Tesia Transverse Magnetic Field.

Conditions used for the 1lquid metal case study are: the transverse magnetic flux density is 5.0 Tesla, the stainless steel channel wall thickness $182.0 \mathrm{~mm}$, the Bartmann number is approximately 2300 , and the 11quid 1ithtum Inlet cetoperature is $230^{\circ} \mathrm{C}$.

F1g. IV-3 Indicates that at $0.5 \mathrm{~kW} / \mathrm{cm}^{2}$ and a veloctty of $5.0 \mathrm{~m} / \mathrm{s}$, both the pumping powex ( $30 \mathrm{~kW}$ per coolant channel) and the vall temperature $\left(590^{\circ} \mathrm{C}\right.$ ) are very large compared to the results for SFB. Detalls of this analysis can be found in the appendix of Ref. 1. 
The advantages and disadvantages of 11quid metal cooling of fHF fusion components in the presence of a transverge magnetic fleld are:

Advantage 8

- Liquid metals have a high thermal conductivity.

- There Is considerable experience In handilng liquid metal aystems.

- Liquid lithium or lithlum-lead can be used both as a breeder and coolant in the blanket.

Disadvantages

- Some liquid metals are corrosive and may not be corapatible with certain structural materials.

- The pressure drop and hence the pumplng power are very large coapared to SPB. If feastble, the destgner should arrange the flow to be parallel to the maguetic field to minimize the pressure drop.

- Liquid metals are more chemically reactive than efther hellum or water.

\section{IV.3 Gomparibon of Three High Heat Flux Heat Removal Techniques}

The three high heat flux removal techniques are compared by examining the heat transfer coefficlents, maximum wall temperature (at the exit of channe1), pumping power, and pressure drop. The conditions for which the comparisons are made are applicable to many of the fusion components such as 1imiters and divertors (in e.g. TFTR and TFCX). For these comparisons, it 18 assumed that the coolant channel is subjected to a uniform heat flux of $0.5 \mathrm{~kW} / \mathrm{cm}^{2}\left(5.0 \mathrm{MW} / \mathrm{o}^{2}\right)$, the channel $1 \mathrm{~s} 1.5 \mathrm{~m}$ long and has an Ingide diameter of $1.0 \mathrm{~cm}$. In the case of liquid metals the fluid is liquid lithium, the transverse magnetic field density is assumed to be 5.0 Tesla, and the coolant channel 18 assumed to be stalnless steel with a wall thickness of $2.0 \mathrm{~mm}$.

Since the design for cooling a fugion component is coupled with many other design constraints (e.g., materfals, and thermal stresses), ouch a design Is machine- and component-dependent. In addition, the thermalhydraulic performance of each heat removal technique has nut been optinized. Therefoce, the results in Figs. IV-I through IV-3 are not opilaized and should not be used for the design of speclfic fuston components.

One limftation placed on the design of a fusion component is the naximum allowable wall temperature. For an 1 mposed heat flux of $0.5 \mathrm{~kW} / \mathrm{cm}^{2}$, the 
wall temperature varfationa are: (1) $147 .{ }^{\circ} \mathrm{C}$ to $236 .{ }^{\circ} \mathrm{C}$ for SEB, (2) $230^{\circ} \mathrm{C}$ (roughened tube) to $320^{\circ} \mathrm{C}$ (anooth tube) Lor high velocity heliun gas cooling, and (3) $444 .{ }^{\circ} \mathrm{C}$ to $590 .{ }^{\circ} \mathrm{C}$ for $11 q u 1 d$ 11thium. At these channel well temperatures, additional comparisons are given in Table IV-1. The pumping power requirements increase by more than an order of magnitude for helium gas when compared to SFB; that for liquid metals ia more than four times that for helfum gas. When the channels are roughened the punping power for hellum gas cooling can be almost two ordere of magnitude above that for SFB. The roughened channel heat transfer coefflclent for hellun gas is about a factor of three below that for fully developed SFB. Because of the high thermal conductivity of 11quid metals, the heat transfer coefficlent is between 58 and $90 \%$ higher than that for hellum gas cooling and between 42 and $30 \%$ below tinat for SFB.

\section{4 Conclusions and Recommendations}

This assessment deals primarily with the heat transfer aspects of fuston component heat removal using three different techniques. In selecting a coolant for a specific fusion component, one must include all the degign constraints. This is cruclal since some of the advantages and disadvantages af each method can only b? brought out by considering all the design conatraints for specific components.

Based on the present technological limtts of heat removal, the estmated capability of each altemative examined is shown in the last line of Table IV-1, which shows that $S F B$ has the greatest heat removal capability followed by hellum gas and liquid metals. In addition, for the same imposed heat flux, SFB is a more efficlent heat removal technique because:

(1) Higher heat transfer coefficients result,

(2) Lower pump1ng power, and hence cost, 18 required, and

(3) Lower coolant channel wall temperatures reBult.

Since SFB is the most efficient heat removal technique, the cricical issues and engineering research and development (R\&D) needs to develop this coolIng methad for HHF fusion components are summarized next. The prioritized critical 18gues for HHF SFB heat renoval from fugion components are: 
TABLE IV-1: Compar1son of Three High Heat Plux Heat Renoval Altematives*

\begin{tabular}{|c|c|c|c|c|}
\hline & Subcooled & $\begin{array}{c}\text { High } \\
\text { Helium } G\end{array}$ & $\begin{array}{l}\text { Yelocicy } \\
\text { as Cooling }\end{array}$ & $\begin{array}{l}\text { Llquid } \\
\text { Metalt } \\
\text { Cooling }\end{array}$ \\
\hline & $\begin{array}{l}\text { F1ow } \\
\text { Bo1ling (SFB) }\end{array}$ & $\begin{array}{l}\text { Smooth } \\
\text { Channel. }\end{array}$ & $\begin{array}{l}\text { Roughened } \\
\text { Channel }\end{array}$ & $\begin{array}{l}\text { (Liquid } \\
\text { Lithiun) }\end{array}$ \\
\hline $\begin{array}{l}\text { Invest igated Interval for } \\
\text { wa11 temperature: } \\
\text { (i) Lower exit wall } \\
\text { temperature (LEHT) }\left({ }^{\circ} \mathrm{C}\right)\end{array}$ & 147 & $250 * \star \star$ & $230 * \hbar \star$ & 435 \\
\hline Flow condicton & $16 \mathrm{Mg} / \mathrm{I}^{2} \mathrm{~s}$ & $300 \mathrm{gm} / \mathrm{s}$ & $110 \mathrm{gII} / \mathrm{s}$ & $10.0 \mathrm{~m} / \mathrm{s}$ \\
\hline $\begin{array}{l}\text { (11) Upper exit wall } \\
\text { temperature (UEWT) }\left({ }^{\circ} \mathrm{C}\right)\end{array}$ & 236 & 365 & 365 & 590 \\
\hline Flow condition & $7.3 \mathrm{Mg} / \mathrm{m}^{2} \mathrm{~s}$ & $140 \mathrm{gm} / \mathrm{s}$ & $65 \mathrm{gm} / \mathrm{s}$ & $5.0 \mathrm{~m} / \mathrm{s}$ \\
\hline $\begin{array}{l}\text { Pumptng power (kw) per } \\
\text { coolant channel at: }\end{array}$ & & & & \\
\hline (i) LEWT & 1.4 & 45.0 & 20.0 & 118. \\
\hline (ii) UEWT & 0.12 & 10.0 & 7.5 & 30 \\
\hline $\begin{array}{l}\text { Heat transfer coefficient } \\
\text { (h) at LEWT }\left(\mathrm{kW} / \mathrm{m}^{2} \mathrm{~K}\right)\end{array}$ & $118 . * \star$ & 20. & 43. & $\begin{array}{l}68.05 \mathrm{~m} / \mathrm{s} \\
82.010 \mathrm{~m} / \mathrm{s}\end{array}$ \\
\hline
\end{tabular}

\begin{tabular}{|l|l|l|l|l|}
\hline $\begin{array}{l}\text { Present technological 1Im1Ls } \\
\text { on Imposed heat flux for } \\
\left.\text { fusion components (kW/ } \mathrm{cm}^{2}\right)\end{array}$ & $\begin{array}{c}0.5(\mathrm{~L} / \mathrm{D} \\
<200) \\
8.0(\mathrm{~L} / \mathrm{D} \\
(50)\end{array}$ & $1.0 * *$ & $2.0 *$ & 1.0 \\
\hline
\end{tabular}

*Caution: These resultg ghould not be uged for degign purposes since chere are other coupled constraints unique to specific fuston components which have not been included. The comparioons are made for the following condit1ons: $0.5 \mathrm{~kW} / \mathrm{cm}^{2}$ Uniform Feating; C1rcular Coolant Channel; $\mathrm{L}=1.5 \mathrm{~m}, \mathrm{D}=1.0 \mathrm{~cm}$.

**If enhancament techniques are lncluded $h$ wlll be higher. The SPB predictions are applicable for an inlet subcooling of $180 \mathrm{~K}$ and exit pressure of $1.55 \mathrm{MPa}$.

***L1mited by the coolant maximum Mach number $<0.5$.

TThe transverse magnetic fleld was assumed to be 5.0 Tesla; the coolant channel was assubed to be stainless ateel with a $2.0 \mathrm{~mm}$ wall thickness.

\#Limited by maximum external tube wall temperature $<550^{\circ} \mathrm{C}$ for Prime Candidate Alloy (PCA: 316 gtalnless steel doped wth titanlum) wth a wall thickiess of $1.0 \mathrm{~mm}$.

\#\#For the high velocity helfum gas cooling technological $11 m i$ ts of 1.0 ano 2.0 $\mathrm{kH} / \mathrm{cm}^{2}$, the pumping power is very high, 1.e., approximately 190 and $275 \mathrm{~kW}$ per channel, respectively. 
(1.) Bvaluation of SPB CHF between 0.1 and $2.0 \mathrm{kH} / \mathrm{cm}^{2}$ for large surface ared $\left(0.1\right.$ to $100 . \mathrm{m}^{2}$ ) fuston couponente with large $\mathrm{L} / \mathrm{D}$ ratio (50 to $600)$ coolant channels. The CHF data bese in this range is sparce or nonexistent and 18 essential to the design of nesr-tern fusion conponents.

(2.) Establishing the SFB thermal-hydraulic stability criteria of multiple, Interconnected, and subchannel coolant conduits $1 \mathrm{~s}$ essential to near-term component design. However, this becomes less important if the slope of the pressure-drop/flou-rate curve of each coolant channel is required to be positive or greater than the pump's performance curve.

(3.) Increase the understanding of the physical mecheniams leading to SFB CHF In order to develop engineering thermal-hydraulic models which can be used to characterize the data base.

The prioritized engineering RED needs for HHF SFB heat removal from fusion components are:

(1.) Develop unconditionally stable SFB CHF and pressure loss data for single and multiple coolent channels with heat fluxes between 0.1 and $2.0 \mathrm{~kW} / \mathrm{cm}^{2}$ and determine the quantitative effects of surfactant additives, binary mixtures, gwirl flow, and helical subchannels relative to stable axia1-flow data.

(2.) Perform linear (and later nonlinear) thermal-hydraulic stabilfy analyses to examine, e.g., the Ledinegg, flow pattern transition, parallel channel, and condensation-induced instabilities. The fusfon component flow channel design will not be complete without such an analysis.

(3.) The mechanistic understanding of conditions leading to SFB CHF must be increased by:

(a.) Developing engtneering mode1s, for SFB CHF characterization, based on first principles which relate the applied heat flux to both the bulk SFB parameters (velocity, heated lengtb, diameter, inlet temperture, exit preseure, and thermophysical properties) and local SFB parameters (e.g., vold fraction distribution; minimum, mean and maximum bubble aize; bubble density; and boundary lager ithickinesses). 
(b.) Perforing flow vigualizations to observe bot hydrodynante and therwal characterlaticg whtch will lead to an overall understanding of SFB CAF and provile guidance In engineering codel development.

The prloritized enfineering RsD neede for high velocity heliun gag convectIon for HHF removal fron tusion components are:

(1) Extend the existing heat transfer and friction data from annular geometries to tubular-ţpe geonetrles.

(2) Determine the appropriate nanufacturing techniques for two.: and threedimensional roughened aurfaces.

Finally, the priorttized RSD needs for liquid metal heat transfer in the presence of a transverse magnetic fleld for Hof heat removal for fusion components are:

(1) Determine the effect of high Hartasnn number, nonuniform magnetic flux density, non-cireular cross-section and nonunfform coolant channel wall thickness on the velocity distribution and the heat transfer, and

(2) Determine the significance of natural convection (1n large conduits, e.g., In blanket and first wall applications), and the thermoelectric (or Seebeck) effect. 


\section{RERRENCES FOR GHAPIER IV}

1. Boyo, R. D., Wong, C. P. G., Cha, Y. S., "Technfcal Asgessnent of ThermalHydraulics for High Heat Flux Fuston Appltcations," SAND84-0159, Sandia Nat Lonal Laboratortes, Albquerque, NM, 1984. 
CHAPTER V

THERMOMECHANICAL RESPONSE

Lead Author:

R. D. Watson (SNLA)

Contributors :

J. R. Easoz (West Inghouse)

A. M. Hassanein (ANL)

R. F. Mattas (ANL)

D. L. Sevter (GA)

W. G. Wolfer (UW) 


\section{v. THERMOMECHANICAL RESPOISE}

\section{V.1 Thermal Response}

High heat flux components must be adequately cooled to proper1y perform their functions. The method of cooling, whether passtve or active, depends strongly on the applied heat flux, pulse length, thermal properties, and the maximum allowable temperacure.

\section{V.1.1 Passive Cooling}

Passtve cooling is limited by the reat capacity, melting point, and surface emissivity of the material. This $11 \mathrm{mit}$ can be determined by estiwating the heat flux required to melt the surface of a "therwally thick" object $(1)$.

$$
\begin{array}{rlrl}
q_{\text {me1t }} & =\frac{1}{2} \sqrt{\frac{\rho C_{p} k}{t_{p}}}\left(T_{m}-T_{0}\right) & & W / \mathrm{cm}^{2} \\
q_{\text {me1t }} & =\text { heat flux } & & \\
& =\text { density } & & \mathrm{W} / \mathrm{cm}^{2} \\
C_{p} & =\text { specific heat } & & \mathrm{g} / \mathrm{cm}^{3} \\
k & =\text { thermal conductivity } & & \mathrm{W} / \mathrm{g}-\mathrm{K} \\
\mathrm{t}_{\mathrm{p}} & =\text { pulse length } & \mathrm{cm}-\mathrm{K} \\
T_{\text {m }} & =\text { melting point } & \mathrm{K} \\
T_{0} & =\text { Initial temperature } & \mathrm{K}
\end{array}
$$

This equation is plotted in Fig. $\forall-1$ for gine selected materials. For heat fluxes in the range of 10 to $100 \mathrm{~W} / \mathrm{cm}^{2}$ (first walls), passive cooling is sufficlent for both existing and near-term devices but not for long-term machines with pulse lengths greater than $100 \%$. For heat fluxes in the range of 100 to $1000 \mathrm{~W} / \mathrm{cm}^{2}$ (limters, itvertor collecto- plates, halo scrapers, etc.), passive cooling becomes barginal for near-ter'm machines and w11 not work for long-term wachines. For heat fluxes frow 1000 to $10000 \mathrm{~W} / \mathrm{cm}^{2}$ (neutral beam dumpe), active cooling is required for any fusion device with pulse lengtha greater than 1 to $5 \mathrm{~s}$. Finally, for heat fiuxes greater than $10000 \mathrm{~W} / \mathrm{cm}^{2}$ and pulse lengths on the order of 10 ms (plasma disruptions), active cooling will not be able to prevent surface melting or vaporization 


\section{SURFACE HEAT FLUX TO MELT SURFACE}

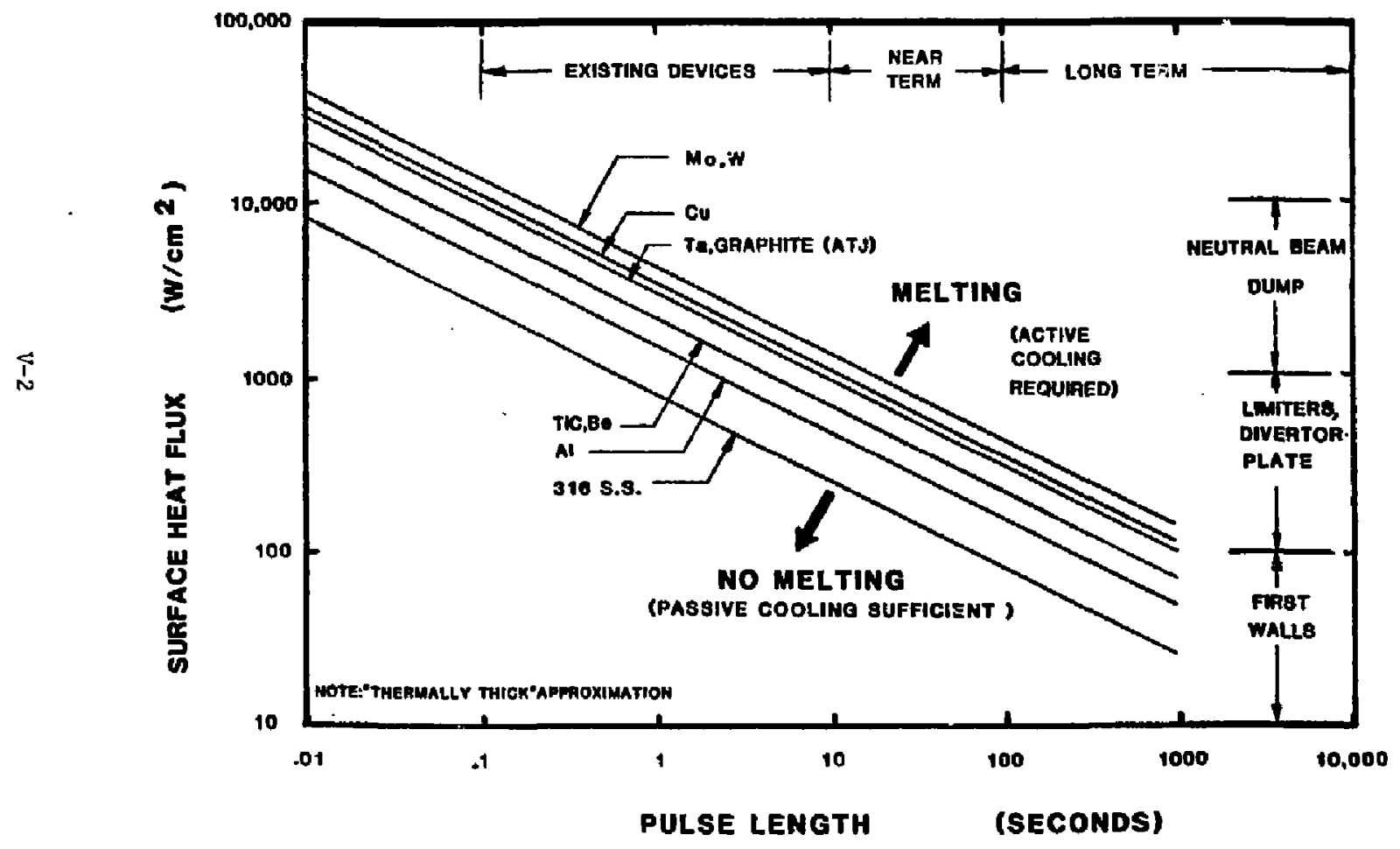

Figure V-1. Combinations of surface heat flux and pulse length required to melt the surface of an uncooled, "thermally thick" material. 
since the thermal diffusion length to typtcally web shorter than the cooling channels' wall thlekness.

The best matetials for absorbing a short pulse of heat without melting are those that have a high value of $\left(T_{m}-T_{o}\right) \sqrt{o C_{p} k}[$ [ee Eq. (1)]. Figure $V-2$ shows that Mo, $W$, and $W$ have the highest heat aboorption capacity awong the high-2 materials ( $\mathrm{Z}>24)$. VC, TAC, and TiN rank the highest among medium-Z materials $(16<z<24)$, wise graphtte, $B N$, and $B_{4} C$ rank the best among low- $z$ materiale $(z<16$ ). It 1s interesting to note that although 316 stainlesg steel has the lowest heat absorption capacity of all the materials listed in Fig. $\mathrm{V}-2$ (except for $\mathrm{Be}_{2} \mathrm{C}$ and $\mathrm{SI}_{3} \mathrm{~N}_{4}$ ), it is currentiy used ta existing. fusion devices as a limiter material due to Its high ductility and excellent fracture toughness.

\section{V.1.2 Act1ve Cool1ng}

Since active cooling will be needed for wost high heat flux components in future devices, this implies the use of a relatively thin wall separating the plasma side material from a high velocity coolant. Steady-state conditions will exist and temperature proflles through the thickness will be approximately innear. The maximum steady-state heat flux needed to melt the surface is given by:

$$
\begin{array}{rlrl}
q_{\text {me1t }} & =\frac{k\left(T_{\text {m }}-T_{b}\right)}{h} & & \mathrm{~W} / \mathrm{cm}^{2} \\
q_{\text {melt }} & =\text { heat } \mathrm{flux} & & \mathrm{W} / \mathrm{cm}^{2} \\
\mathrm{k} & =\text { thermal conductivity } & \mathrm{W} / \mathrm{cm}-\mathrm{K} \\
\mathrm{T}_{\mathrm{m}} & =\text { melting polnt } & \mathrm{K} \\
\mathrm{T}_{\mathrm{b}} & =\text { backside temperature } & \mathrm{K} \\
\mathrm{h} & =\text { wall thicknegs } & \mathrm{cm}
\end{array}
$$

Figure $v-3$ shows that $W, C u$, and Mo have the best heat conduction capacity among the high-z materials. For medium-2 material, TIC and vC are good, while among the low-Z materials, SAC, BeO, graphite, and Be rank the best. In ptactice, however, the maximum allowable temperatures will be significantly lower than the melting polat due to radiation damage, 1088 of mechanical properties, corrosion, vaporization losses, etc. 


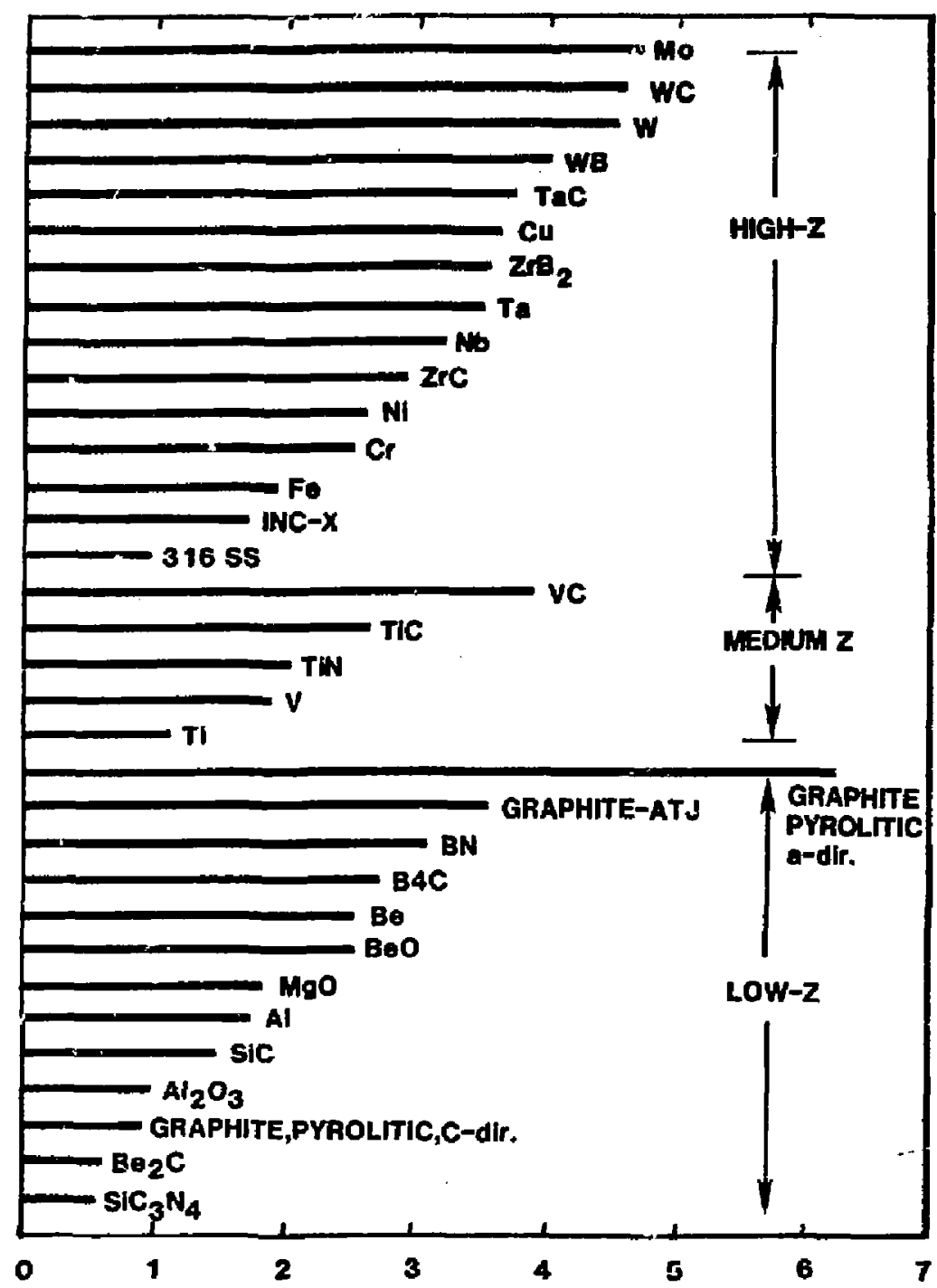

HEAT CAPACTY FIGURE-OF-MEAT $\left(T_{m}-T_{0}\right) \sqrt{\rho C p K} \mathrm{KJ} / \mathrm{cm} \sqrt[2]{\mathrm{sOC}}$

Figure v-2. Heat capacity figure-of-merit. Larger numbers imply that more heat can be absorbed in a given amount of time without melting. 


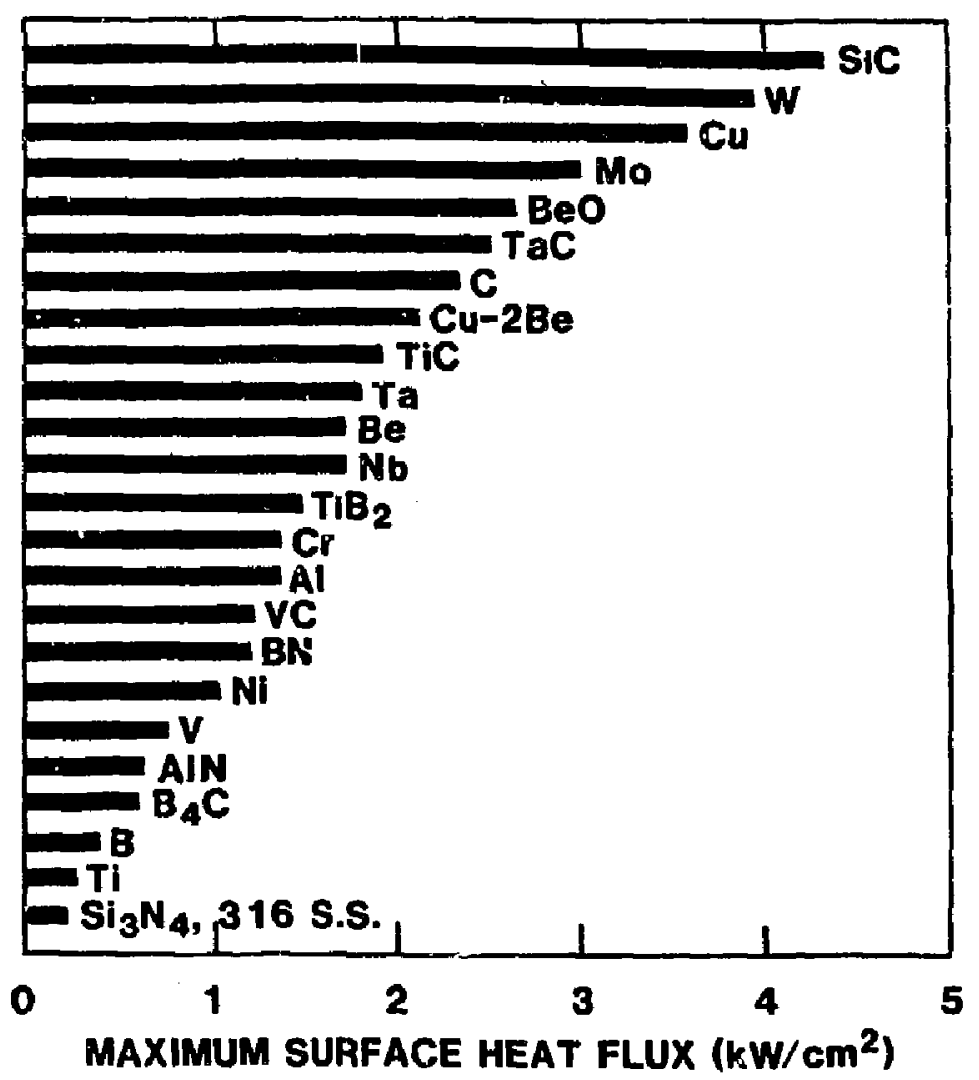

Figure V-3. Maximum heat flux needed to melt the surface of a $1 \mathrm{~cm}$ thick plate cooled on its backside to $100^{\circ} \mathrm{C}$ during steady-state conditions. 


\section{V.1.3 Thereal Response to Plasma Disruptions}

In exisi:Ing tokamaks, plasna disruptions can occur frequent1y, deposifsig enetgy denatiles from 100 to $1000 \mathrm{~J} / \mathrm{cm}^{2}$ over time perlods from $10 \mathrm{ps}$ to 10 ms. The beat materials for resisting plaswa disruptions heve high welting points, low vapor pressures, and high values of $\rho, C_{p}$, and $k$. Figures $V-4$ and $\mathrm{V}-5$ show theoretical predictions of melting and vaporization. Figure $\mathrm{V}-4$ shows that $W, T I C$, and BeO have sualler melt layers than Be, Ta, $316 \mathrm{SS}$, or Cu. Figure $V-5$ shows that $W, T a$, and $\mathrm{Cu}$ are more resistant to vaporization than BeO, Be, and 316 sS. Tt and S1C fall in the middle of these two extremes.

Due to the lack of experimental data, Iffetime predictions have relled heavily on computer predictions. These codea have progressed algnificantly in recent years but need improved models for vapor shtelding. These codes need to be compared with electron and fon beam simulations. Two-dinensional effects of the e-beam spot size and power distribution need to be accounted for. Also, the question of melt layer stablity in a pulsed electromagnetic field is a serious issue that needs to be addressed both theoretically and experimentally.

\section{V.1.4 Irradiation Effects}

Lattice defects produced by neutron Irraciaticn will decrease the thermal conductivity due to the increase in resistance to phonon transport. The effect is strongest for non-metals. For example, the thermal conductivity of Sic is known to be reduced by a factor of four after exposure to a neutron fluence of $10^{22} \mathrm{n} / \mathrm{cm}^{2}$ at $800 \mathrm{~K}^{(2)}$. Graphite, BeO, and T1C would experience stoflar behavior. This implies that thinner armor tiles would have to be uged in order to minimize thermal stresses then the irradiated properties are used. In the case of SiC, this results in a factor of four facrease in the lifetime when aurface eroston is the Iffe-11miting factor.

\section{V.1.5 Thermal Analyols Computer Codes}

There are currently avallable a wide virlety of sophleticated finite element ind finte difference computer codes that are suitable for thermal analysis of high heat flux components. Hany capabilitfes extst: transient, 


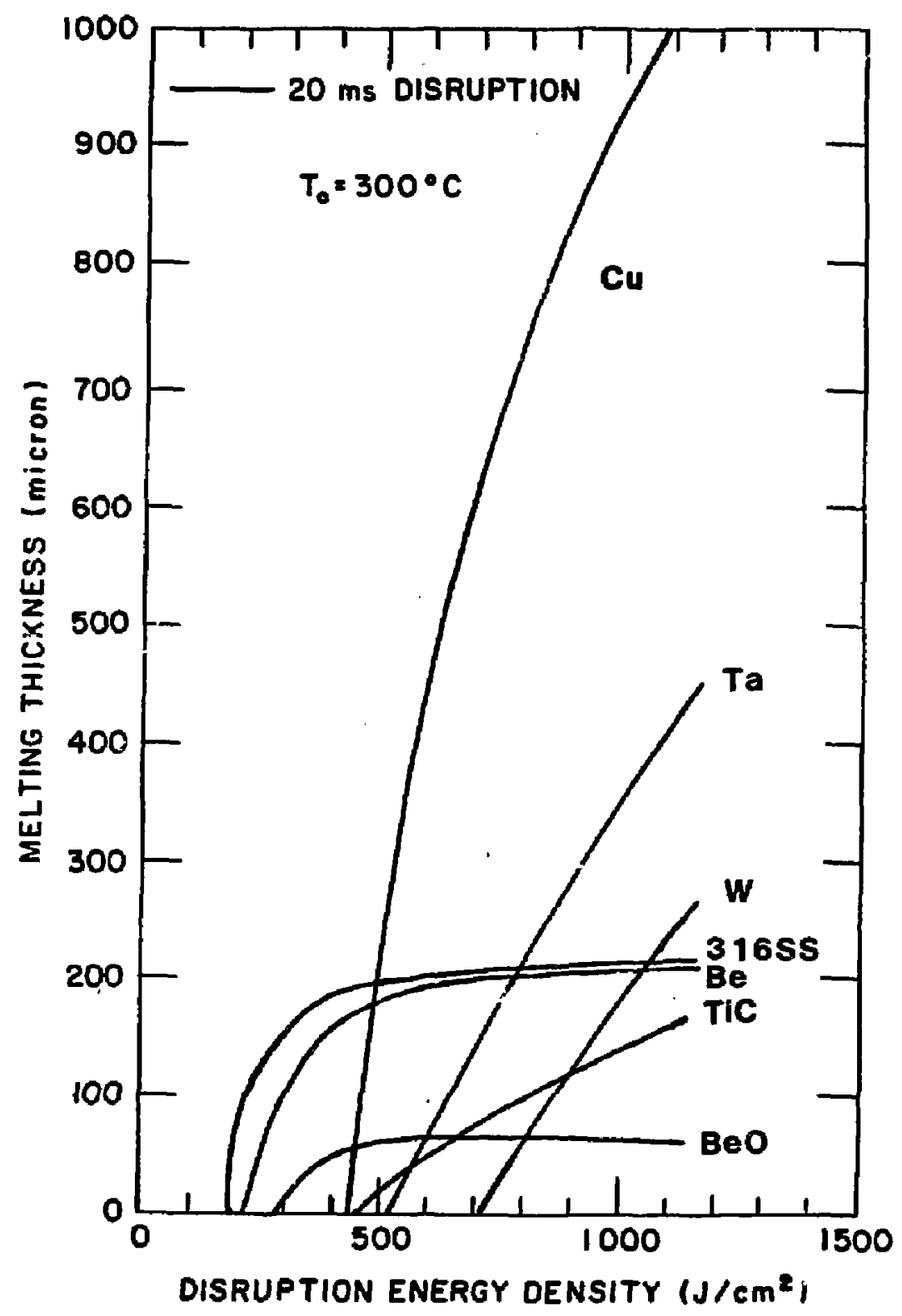

Figure V-4. Amount of material melted during a $20 \mathrm{~ms}$ plasma disruption. 


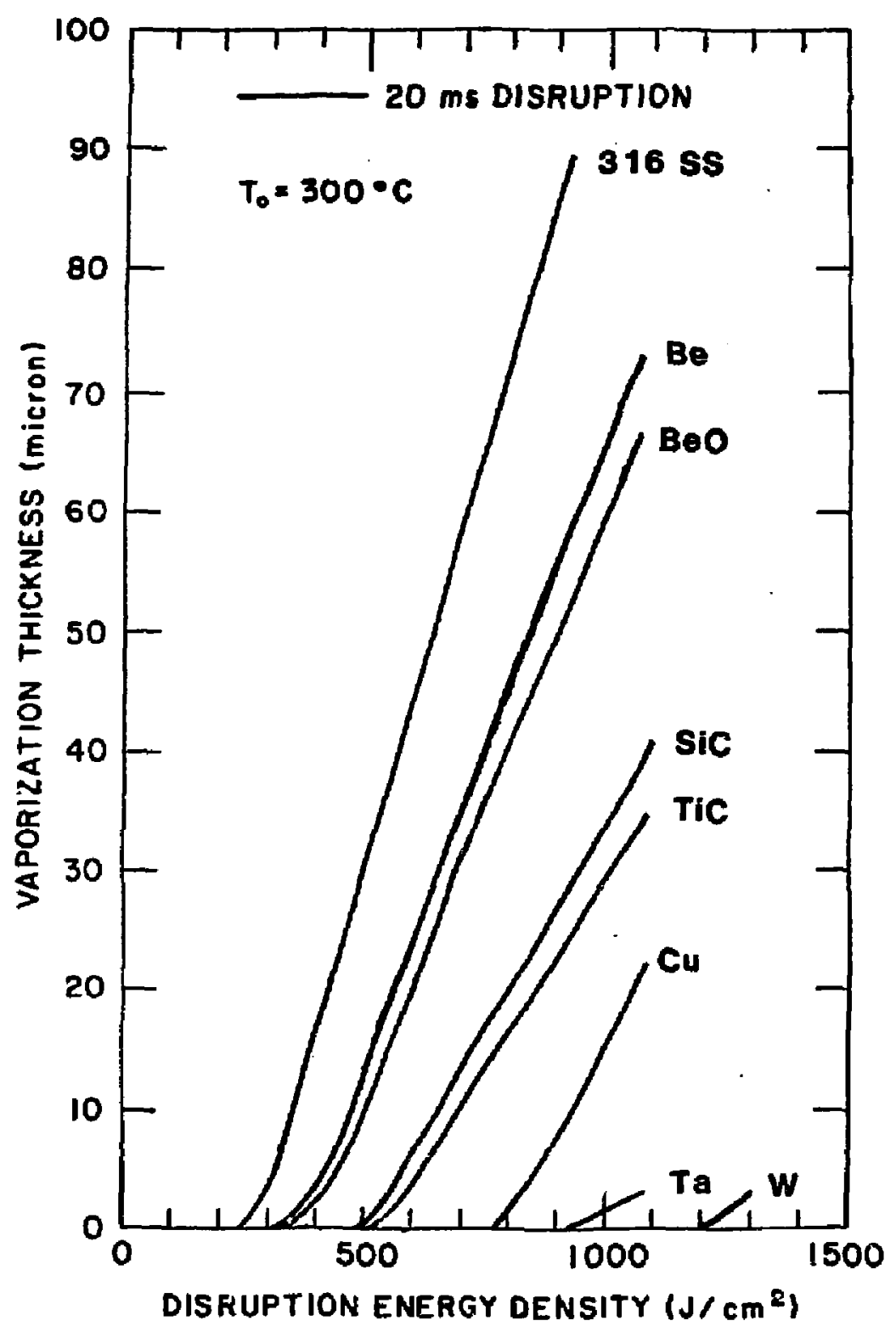

Figure V-5. Amount of material vaporized during a $20 \mathrm{~ms}$ plasma disruption. v-3 
3-D solutions; thernal radiation; non-linear, anisotropic theraal properties; gap conductance models; phase change capabllity; coupled heat transfer/otress analygis solutions; etc.. The capabllities of these codes are adequate for conceptual design st:dies and analysis of experinents.

The accuracy of these predictions will be 1mproved by a better knowledge of the boundary conditions, in particular, the applied heat flux on the plaswa side and the heat transfer coeffictent on the coolant side. There is a need for computer programs that can calculate the detalled heat flux profile on an arbitrarily shaped surface as a function of (1) the plasma scrape-off distance; (2) power sharing and connection lengths between limiters, antennas, etc.; and (3) the motion of the plasma during distuptions. More accurate correlations are needed for heat transfer with high velocity, sub-cooled nucleate bolling wacer.

\section{V.2 Structural Response}

Stresses and deformations in high heat flux components are caused by five types of loads: (1) gravity, (2) coolant pressure, (3) electromagnetic forces, (4) thermal expansion, and (5) Irradiation creep and owelling. Dead welght loads due to gravity are typlcally saall and easily managed. Likewfsr, for actively cooled designs wich coolant pressures on the order of $10 \mathrm{MPa}$, hoop stresses are noc large becauge the raclo of channel radius to wall thickness is typlcally less than 10 . Electromagnetic forces caused by eddy currents induced by plasma distuptions can cause large transient stresses. This is discussed in the Chapter VI, Electromagnetic Response. Thermal stresses and radiation effecte are discussed in this chapter.

\section{V.2.1 Thermal Stresses}

Thermal atresses are caused when temperature changes induce thermal expansion in a constrained material. The degree of constraint strongly affects the stress level and depends on both the method of thermomechanical atcachment and on the non-11nearity of temperature gradients within the structure. As an example, graphite limiter tfles used in existing fusion devices are mechanically bolted to support plates because high thermal conductance to the support plate is not required to actively remove heat during the short pulses. 
Thermal streases are consequently lower because the tile is relatively free to expand and rotate. However, for longer pulse lengths, the tiles need to be Ilgidly bonded to an actively cooled heat alnk. This increases thermal otresses because of the atffer mechanical constraint. Thermal atresaes caused by plasma disruptions will be very large at the heated ourface because the non-1inear temperature gradient Induces a high degree of self-constraint within the tile, Independent of the cype of wechanical attachment.

Thermal atresses are proportlonal to EabT $(1-v)$, where E - Young's Modulus (MPa), $\alpha$ = thermal expansion coefficlents $\left(K^{-1}\right), v=$ Polsson's Rat 10 , and $\Delta T=$ temperature difference $(K)$. If the structure is passively cooled, then $\Delta T \sim\left(\mathrm{pC}_{\mathrm{P}} \mathrm{K}\right)^{-1 / 2}$. Therefore, an appropriate figure-of-merit for transient thermal stresses is given by the dimensionless ratio of yleld strength to thermal stress:

$$
\begin{aligned}
& \text { Transient Thermal Stregs } \\
& \text { Figure-of-Merit }
\end{aligned}=\frac{\sigma_{y}(1-v) \sqrt{\rho C_{p}}}{E \alpha}
$$

Figure $V-6$ shows that graphite, Gu, and Mr alloys can sustain the largest heat pulses befare ylelding.

For actively cooled components, steady-Btate conditions are reached and the temperature differences are simple proportioual to the thermal conductivity, $\Delta T \sim k$. In this case, the approprlate dimenstonless figure-of-merit is given by:

$$
\begin{aligned}
& \text { Steady-State Thermal Streas } \\
& \text { Figure-of-Merit }
\end{aligned}=\frac{\sigma_{y}(1-\nu) \mathbf{k}}{E a}
$$

Figure $V-7$ shows that graphite, $\mathrm{Cu}$, and Mo alloys also have the lowest dimensionless thermal stresses during steady-state conditions.

Practical expertence confirus these rankings. Passively cooled limiters on TPTR, D-III, ISX-B, etc. that are made of TIC-coated graphite have exper1enced no structural fallure after many thousands of cycles. Actively cooled neutral beam dumps are currently made of elther bare copper or molybdenum alloys and have demonstrated successful performance at heat flux levels up to $8000 \mathrm{w} / \mathrm{cm}^{2}$ steady-state ${ }^{(3)}$ 


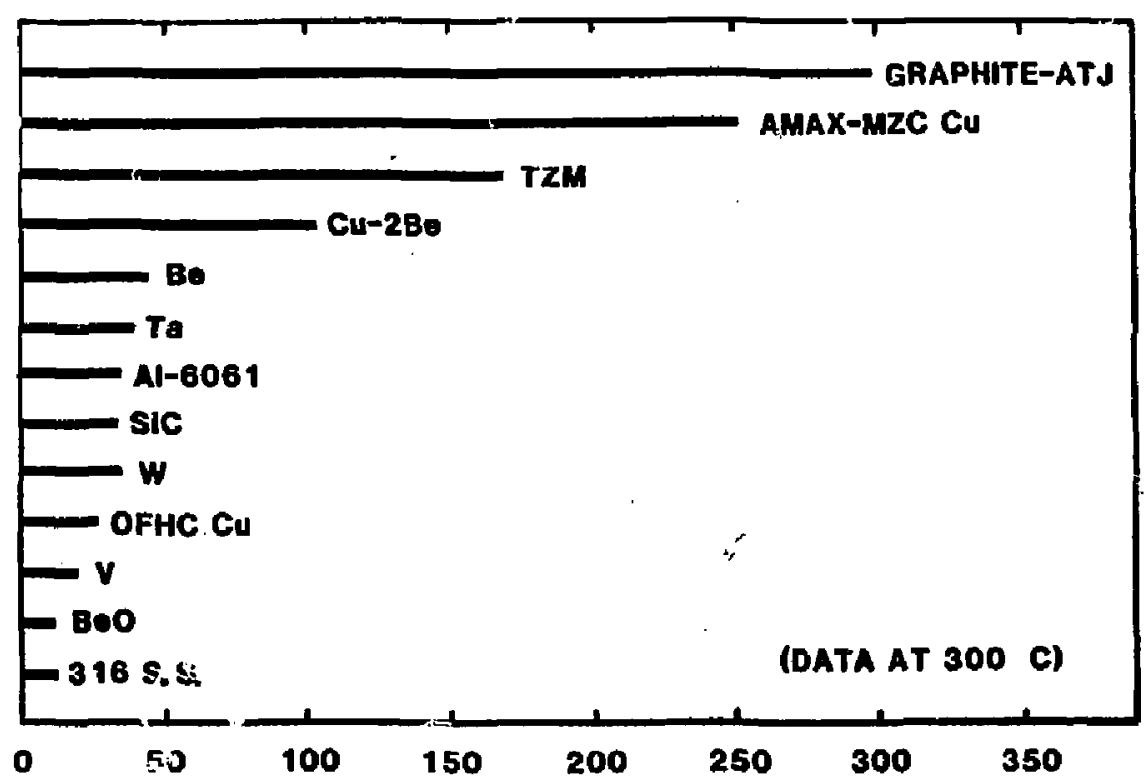

\section{THERMAL STRESS FIGURE-OF- MERIT $\frac{(1-V) \sigma_{y} \sqrt{p C_{p} K}}{E \propto} \cdot$ (ARB. UNITS)
(TRANSIENT)}

Figure V-6. Thermal stress figure-of-merit for transient heating. Higher values of the figure-ofmerit imply that nore heat can be absorbed during

a given amount of time without yielding the material. 


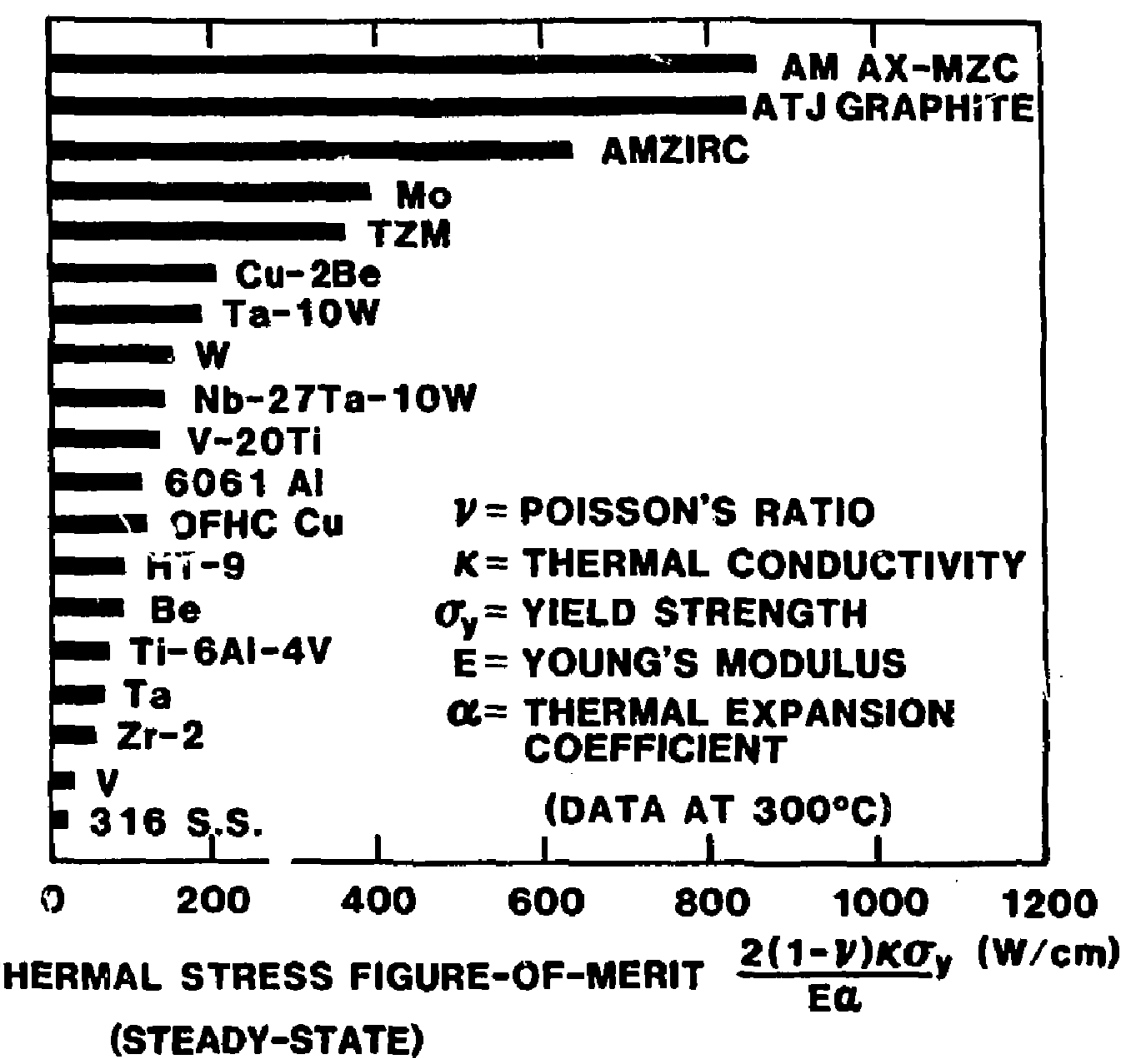

Figure V-7. Thermal stress figure-of-merit for stealy-state heating. Larger values imply that greater heat fluxes can be removed steady-state without yielding the material. 
; There is 1fttle experience in the fusion comunity with actively cooled duplex or triplex components constructed of thick $(\sim 1 \mathrm{ca})$ araor tiles bonded to a netallic heat sink, as shown 1n F1g. V-8. The armor, cover plate, and base plate naterials can be chosed independently in order to optinize performance. Since the heat gink is protected fron disruptions and surface erosion, then thin-walled cover plates ( 1 to $5 \mathrm{~mm}$ ) can be used to ninimize thermaj. stregses. Likewloe, the base plate wlll have low themal stresses if the cooling channels are placed near the plasm alde. The armor miterial will have the largest thermal stresses since the thickness required for erosion protection results in a large temperature drop across the tile. Also, the tnterface between the armor and heat Bink will be subject to large shear stresses due to differential thermal expangion. Fortunately, cracking of armor is less serious than a coolant leak or bond detachment.

\section{V.2.2 Thermal Stresges from P1asma Digrupt1ons}

Plasma disruptions will induce large compressive thermal stresses at the surface. At these high temperatures, the material can easily plastically deform and creep, resulting in residual tengtle stresses at the surface after cooldown. These stresses may be sufficleatly large to cause reverse ylelding and surface microcracking if the materlal's ductility 1s low. Th1s mechanisw of cracking has been observed on TIC-coated groph1te liniters in ISX-B, D-III, TFTR, and on cargets of 316 SS and Be that have been tested In ESURF and the Sandia electron-beam test facility. In principle, these microcracks can grow and coalesce Into \& large surface flaw that may contrine to grow due to normal operating etresses. Th is is a concern primarily for long-term machines.

\section{V.2.3 Irradiation Effects on Structural Response}

In future fuston devices such as ETR, INTOR, DEMO, and commerrial reac-tora, neutron irradiation damage will algnificantly affect the distribution cf otresses in high heat flux components. For example, the decrease in therwal conductivfty of non-metallic materials will increase s-resses over time. Forcunately, Irradiation creep will prevent the unlimiced buildup of these stresses. Predictions by Inelastle computer coder have shown that owelling stresses can reach the same nagnitude as thermal stresses ${ }^{(4)}$. Unlike therail stresses which fatigue cycle with each pulse, swelling stresses are pe.manently locked into the atructure. 


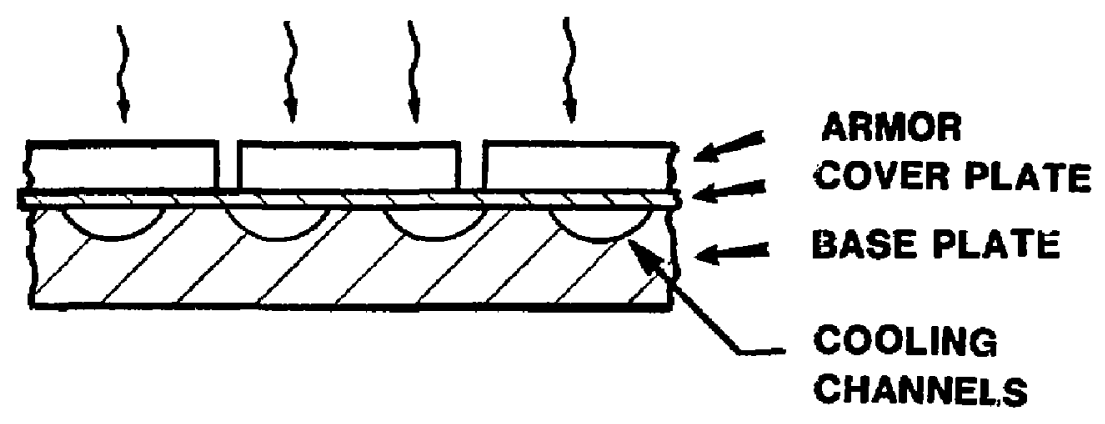

Figure V-8. Triplex 3-layer construction of a high heat flux component, 
Differeatial swelling between different layers of a duplex structure will produce a complex stresg state and way eventually cause debonding at the interface. In addition, the permanent deformations caused by owelling and creep nay prevent easy removal of components for malntenance. The accuracy of the predictions 18, of course, lisited by the sparse data base on creep and swellfng of copper, molybdenum, cantalum, and tungaten alloys as well as the non-metallic plasma-side materials.

\section{V.2.4 Stress Analys18 Computer Codes}

There are currently avallable a wde varlety of cophioticated finfte element computer codes that can accurately predict the otresges and displacements of high heat flux components. The capabilittes of these codes include: 3-D, transient solutions; large deformations; elastic-plast1c, non-11near, viscoelastlc, anlsotropic, temperature dependent materfals mode1s; sliding boundarles; creep and swelling models; coupled heat transfer/streas analysis solutions; etc. Efficlent Interactive pre- and post-processor programe are also available. Their accuracy is primarily limted by constitutive models for high temperature waterial behavior with comblned cyclic loading.

\section{V.3 Eallure Anatysib}

The successful operation of high heat flux components depends on a good understanding of the potential modes of fallure. This requires that predictions of the thermomechancal response be integrated whth models for damage accumulation. Fur existing and nesr-term fusion devices, the ASME Boiler and Pressure Vessel cade used by the fission indugtry has provided an excellent set of standsrds and design criterla for protecting agalngt structural fallures. However, future machines w111 aubject thege components to more fatigue cycles, higher temperatures, harder disuptions, and neutron radiation damage. Accurate fallure analysis will become more difflcult because of (I) complex synergistic effecta, (2) a sparse data base, and (3) Incomplete damage modela. This section discusses the critical tssues associated with two ateas: time-1ndependent and rime-dependent fallure modes. 


\section{V.3.1 T1ne-Independejt Fallure Yodes}

Time-1ndependent atructural fallures are caused by the siagle application of an excestive load. These are listed in Table $\nabla-1$. In general, the wodelo for predicting these types of fallures are not well understood. For onet1me load, synergistic effects are not 1mportant, except for gituations where one fallure leads to a becond, sore cevere fallure. For exasple, the debondIng of an armor tile fron the heat sink would cause excessive tenperatures, a loss in strength, and finally fracture or welting.

Table V-1. T1me-Independent Fallure Modes
1. Tensile plastic instebility (ductile rupture)
2. Compressive Instability (buckling)
3. Brittle fracture
4. Burnout (critical heat flux)
5. Interface debonding
6. Excessive deformation

It is important to generate materials data on (1) the short-term mechen1cal properties and stress-atrain data at elevated temperatures and (2) interface bond strengths for braze bonds, diffusion bonds, and plasme sprayed coatings at elevated temperatures. Existing test factilties are considered adequate for this purpose.

\section{V.3.2 Time-Dependent Faflure Modes}

The progressive accumulation of danage over an extended perlod of time can eventuslly cause component fallure. The damage can either be localized to areas of high stress concentration or can extend globally over the entire structure. Table V-2 lists the most Important fallure modes.

Global tiwe-dependent fallures are caused by excessive deformation due to creep, swelling, cyclic plasticity, or loss of material. Creep buckling 18 not considered to be a problem. Ratchetting due to cyclic plasticity may cause problens at high heat flux levels and needs to be otudied in more detail. Excessive deformations due to thermal or frradiation creep are not a $v-j 6$ 
Table V-2. Tine-Dependent Fallure Modes

Global

1. Creep buckling

2. Ratchetting (1ncremental growth)

3. Excessive creep deformation

4. Exceso1ye gwelling defornation

5. Wall thinning (corrosion/erosion)

Loca1

6. Creep Instability (necking, thinning)

7. Creep rupture

8. Fast fracture

9. Crack leak-through

10. Interface debonding

concern because the deslgs alloweble creep strain IImitg are typlcally small so as to prevent locallzed creep rupture. Swelling is a more gerlous problem since the removal of components for repair may be prevented by excessive deformatlons. Wall thfining caused by erosion of plasma-side materials or corrosion/erosion of internal coolant channels is also a serious concern. The PMI Task Group is addressing the erosion problem. Hewever, the use of high velocity water cooling may cause significant internal erosion of copper heat sinks.

Localized time-dependent fallures occur in regions of high stress concentration and/or degraded mechanical properties. Table v-3 11ats ten different damage mechanlsms that may contribute to locallzed fallures. Exigting models for fatigue crack 1nitiation and growth are well developed, especially when 11near elagtic fracture mechanics assumptions can be used. These models also Include reductions in the fracture toughness due to embrittlement processes. However, Improvenents are needed for predicting crack propagation through h1ghly non-linear stress flelds and interfaces between bonded layers. 
Table V-3. Danage Mechan18ma

1. Cycl1c plastic deformat1on/crack Init Lat1on

2. Creep defornation

3. Creep cavitation

4. Fatigue crack growth

5. Creep crack growth

6. Hydrogen embrittlement

7. Helium embrittlement

B. Neutron radiation damage

9. Impurity migration to bond interfaces

10. Corrosion

Apart from radiation damage concerns, the maxtmun allowable operating temperatures for high heat flux components wll be determined by creep damage processes. The nucleation and growth of creep cavitles at grain boundarles and near crack tips caused localized creep rupture and creep crack growth in reglans of high atress and temperature. The models for creep damage are not well developed and need improvement. Bue to the pulsed nature of tokamaks, creep-fatigue interactions are expected to accelerate the accumulation of damage, but models are also lacking in this area. Another damage mechanism that is difficult to model is the migration of impurities, gas atoms, or transmutation products to interfaces between bonded layers as the result of stress and temperature gradients. Finally, localized corrosion is $\theta$ concern for some alloys and coolants.

This section has discussed 16 types of potential fallure podes for high heat flux componenta. For nearly all of these, the data base is inadequate for making accurate lifetime assessments. The approprlate use of safety factors (on stress levels, etc.) can relax the need for a large data base, but th1s usually results in an overly congervative design with degraded performance. Nevertheless, there are a number of critical 1saues with regard to fallure analysia and these are sumartzed in Table V-4. 
Table V-4. Critical Isoue for Fallure Analyats

TIME FRAME

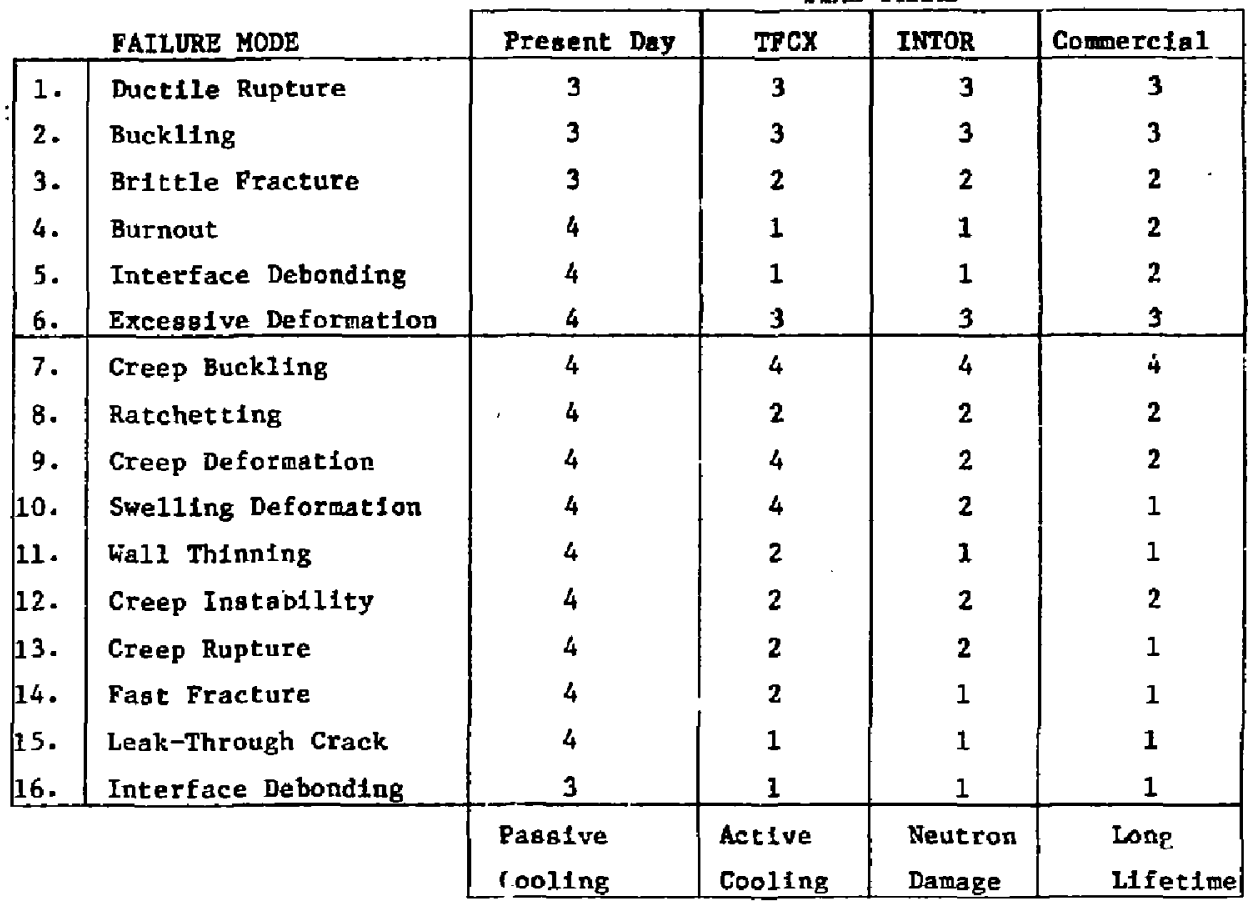

NOTES :

1 x critical 18soue

2 = needed for Improved performance

$3=$ well understood

4 - not important 


\section{V.4 Design Criter1e}

A conmon set of standards and design criteria is needed for structural componeuts in fusion reactora. However, for present-day machines, the ASME Boller and Pressure Vessel Code, Seccions III and VIII for Clase I nuclesr coaponente provides adequate guidelines, data, and design criceria. In the next three to efight yeare, for devices such as TFCX, the ASHE Code Case N47 for Elevated Temperature Service would also be appropriate to use. However, the safety fantors and stress lifits are too conservative to be applied to protective tiles of coatings because they do not constitute a pressure boundary. These limits would not be appropriate to use for the highly locallzed stresses caused by plasme disruptions.

For INTOR and commercial fusion reactora, a new set of standards should be developed that spectfically include the effects of irradiation creep, swelling, embrictlement, disruptions, etc. This new code also chould require a fracture mechanfcs analysis to be perforned, including both fatigie and creep crack growth effects. Since it w11l take many years to rewrite the ASM B\&PV Coded, it is recomended that the "Fast Breeder Reactar Core Conponent Design Criter1. Draft Standards RDT F9-7,8,9" be used in the Interfm. Also, simplifted methods of lnelastic stress analysis should be depeloped. These computer cefes can be easily used in conceptual studies to evaluate the 1mpact on lifet ime of newly developed correlations for materials behavior, in particular, irradiation creep and swelling, erosion, and crack growth.

\section{V.5 Therromechantcal Testing}

The successful operation of high heat flux components in future devices will depend strongly on a dedicated program of thermonechanical testing of prototypes in simulation faclities. Tests on simple geometries allow useful comparisons with model predictions, while prototype tests simulate oynergistic effects that are difficult to predict. Existing wre facilities include the ESURP/ASURF electron beam factlities at Westinghouse and the electron beam test racility (EBTF) at Sandia-Albuquerque (SNLA). Ion beam teet facllitieg Include beam dumps for the Neutral 3eam Englneering Test Facility (NBETF) at Lawrence Liveruore National Laboratory, the Medium Energy Tegt Fac1l1ty (METF) it oak RIdge National Laboratory, the Intense Neutron Source (INS) at SNLA, and the plasna Materfals Test Facility (PMTF) at SNLA, currently under construction. 
Table V-5 sumarizes the reaults af tests of actively cooled conponents completed within the last five years. With the exception of tive berylliun clad stalniess steel duplex structuris, all of the others consisted of a water-cooled heat sink made of a single material, elther copper, molybdenum, or stainlese steel. For heat flux levels under $200 \mathrm{w} / \mathrm{cm}^{2}$, none of the stainless steel heat sinks experienced any, - ructural fallures. From 300 to 1000 $\mathrm{w} / \mathrm{cm}^{2}$, there was no testing done. The no-jbdenum tubes were tested at 1000 to $2000 \mathrm{~W} / \mathrm{cm}^{2}$ without Eaflure up to 600 cycles. From 2000 to $7500 \mathrm{~W} / \mathrm{cm}^{2}$, only copper heat sinks were tested. Wall thlcknesses ranged from 1 to 4 . The METF neutral beam dump has survived 26,000 cycles to date at $5500 \mathrm{H} / \mathrm{cm}^{2}$ and the INS target ran for a total exposure of 140 hours at 4000 to $6000 \mathrm{~W} / \mathrm{cm}^{2}$ before it falled due to a pinhole water leak. These tests are very encouragIng and have demonstrated that actively cooled heat sinks can be succesafully operated at high heat flux levels $\left(\sim 1000 \mathrm{w} / \mathrm{cn}^{2}\right)$ for a significant number of cycles ( 10,000 cycles).

The tests of 2-mm thick beryllium tiles brazed to a 316 ss heat oink were not successful. The large Be tile cracked after 35 cycles at only $50 \mathrm{w} / \mathrm{cm}^{2}$ due to shear stresses, wile the smaller tiles $\left(<2^{n}\right.$ width) did not crack. The testing of duplex and triplex structures is a high priority task since it appears that the performance of duplex structures may not be as good as the single material heat sinks.

\section{V.6 R\&D Needs}

Th1s section discusses the RAD activitles that are needed for 1mproving the thermomechanical performance of high heat flux components.

\section{V.6.1 Extst1ng Mach1nes}

1. 3-D hear Flux Profile Code. A computer program ts needed that can calculate the detaited heat flux profile on an arbitrarily shaped surface as a function of (1) the plasma scrape-off distance, (2) power sharing and connection lengths between 11miters, antennas, etc., and (3) the motion of the plasma during distuptions. This will improve the analygis of thermocouple and Infrared thermography data, and simplify the task of generating heat flux boundary conditions for 3-D finite element thermal analysis. 
Table V-5. Summary of Testing of Actively Gooled Components

\begin{tabular}{|c|c|c|c|c|c|}
\hline EACILITY & INS & EBTF & EBTF & ESURF & ECURP \\
\hline TARGET & $\begin{array}{l}\text { 19-channel } \\
\text { cooling pane1 }\end{array}$ & $\begin{array}{l}\text { 19-channel } \\
\text { cooling pane1 }\end{array}$ & $\begin{array}{l}\text { 4-tube array, } \\
\text { internal fins }\end{array}$ & $\begin{array}{l}\text { 5-channel } \\
\text { coollng panel }\end{array}$ & $\begin{array}{l}\text { oingle } \\
\text { tube }\end{array}$ \\
\hline MATERIAL & ortac copper & oFHC copper & OBHC copper & 316 S.S. & 316 S.S. \\
\hline HEAT FLUR (W/Cm $\left.{ }^{2}\right)$ & $4000-6000$ & 4000 & 7500 & 300 & 300 \\
\hline HALI THICRNESS (ni) & 1 & 4 & 1 & 4 & 4 \\
\hline CFHANNEL I.D. (m) & 2 & 2 & 10 & & 20 \\
\hline PULSE LEWGTH ( $\mathrm{s}$ ) & steady-atate & 10 & 10 & 60 & $50-60$ \\
\hline COOLANT & water & water & water & vater & water \\
\hline PRESSURE (pg1) & 300 & 300 & 300 & $100-1000$ & $100-1000$ \\
\hline VELOCITY $(\mathrm{m} / \mathrm{B})$ & 33 & 35 & 10 & & $0.8-4$ \\
\hline BOILING & yes & yeg & yes & yes. & yes \\
\hline TOTAL CICLES & 200 & 10,000 & 500 & 200 & 200 \\
\hline TOTAL TIME (hre) & 140 & 28 & 15 & 3 & 3 \\
\hline FAILURE MODE & $\begin{array}{l}\text { pinhole leak, } \\
\text { Internol erosion }\end{array}$ & $\begin{array}{l}\text { no leak, suts } 11 \\
\text { surface cracks }\end{array}$ & $\begin{array}{l}\text { pinhole leak, } \\
\text { burnout }\end{array}$ & $\begin{array}{l}\text { no fallure, } \\
\text { plastic deformatio }\end{array}$ & $\begin{array}{l}\text { no } \\
\text { fallure: }\end{array}$ \\
\hline
\end{tabular}


Table V-5. Sumary of Tegting of Act tvely Cooled Components (contiuued)

\begin{tabular}{|c|c|c|c|c|}
\hline PACILITY & ESURF & ESURF & ESURF & ESURF \\
\hline TARGET & $\begin{array}{l}\text { single } \\
\text { tube }\end{array}$ & $\begin{array}{l}\text { cube, with dis- } \\
\text { ruptio: welting }\end{array}$ & $\begin{array}{l}\text { Bingle } \\
\text { tube }\end{array}$ & $\begin{array}{l}\text { elngle } \\
\text { tube }\end{array}$ \\
\hline HATERIAL & $316 \mathrm{~s} . \mathrm{s}$ & 316 S.S. & molybdenum & tolybdenum \\
\hline HEAT FLUX $\left(h / \mathrm{co}^{2}\right)$ & 100 & .00 & 1100 & 2100 \\
\hline HALL THICKNESS (m) & 8 & $\mathrm{~g}$ & 3 & 3 \\
\hline CHANHEL I.D. (Dim) & 20 & 20 & 6 & 6 \\
\hline PULSE LENGTH (B) & 60 & 60 & 2 & 10 \\
\hline COOLANT & vater & water & vater & water \\
\hline PRESSURE (pa1) & $100-1000$ & $100-1000$ & 300 & 300 \\
\hline VELOCITY $(\mathrm{m} / \mathrm{s})$ & $0.8-4$ & $0.8-4$ & $16-24$ & $16-24$ \\
\hline BOILING & no & no & no & no \\
\hline COTAL CYGLES & 500 & 100 & 600 & 30 \\
\hline LOTAL TIME (hrg) & 8.3 & 1.7 & 0.3 & 0.1 \\
\hline FAILURE LODE & no fallure & no fallure & no fallure & no fallure \\
\hline
\end{tabular}


Table V-5, Sumary of Testing of Actively Cooled components (continued)

\begin{tabular}{|c|c|c|c|c|c|}
\hline FACILITY & ASURF & ASURF & ASURF & METF & NBETE \\
\hline TARGET & $\begin{array}{l}\text { MFTF-B end cell } \\
\text { cooling panel }\end{array}$ & $\begin{array}{l}\text { MFTF-B end cell } \\
\text { coolling panel }\end{array}$ & $\begin{array}{l}\text { Duplex } \\
\text { cosling panel }\end{array}$ & $\begin{array}{l}\text { owirl tube neu- } \\
\text { tral beam dump }\end{array}$ & $\begin{array}{l}\text { heat absorb- } \\
\text { tlon panel }\end{array}$ \\
\hline MATERIAL & copper & 304 S.S. & $\begin{array}{l}\text { Se brazed to } \\
316 \text { S.S. }\end{array}$ & $\begin{array}{c}\text { OPHC } \\
\text { copper }\end{array}$ & $\begin{array}{l}\text { Anzirc } \\
\text { copper }\end{array}$ \\
\hline HEAT PLUX $\left(\omega / \mathrm{ca}^{2}\right)$ & 150 & 150 & 50 & $5: 00$ & $1100-1600$ \\
\hline HALl, THICXNESS (m) & 1.3 & 1.3 & $\begin{array}{l}2 \operatorname{me} \\
316 \text { s.s. } \\
\end{array}$ & 1.6 & 2 \\
\hline CHAHNEL I.D. (m) & $19 \times 1$ & $13 \times 2$ & $19 \times 13$ & 6.3 & $2 \times 1$ \\
\hline pULSE LENGTH (s) & 15 & 25 & 60 & $0.5-30$ & 30 \\
\hline COOLANT & water & water & water & water & vater. \\
\hline PRESSURE (PBI) & 125 & 125 & 1000 & 150 & 200 \\
\hline VELOCITY (n/e) & & & $0.2 \times 1.0$ & 12 & 17 \\
\hline BOILING & no & no & no & yes & yes \\
\hline TOTAL CRCLES & 3400 & 10,000 & 35 & 26,000 & 10,000 \\
\hline TOTAL TIME (hre) & 14 & 69 & 0.6 & 22 & 80 \\
\hline FAILURE MODB & no failures & no fallures & $\begin{array}{l}\text { fracture of large } \\
\text { Be tile, no fallur } \\
\text { of gnall se tiles }\end{array}$ & $\begin{array}{l}\text { no } \\
\text { fallures }\end{array}$ & $\begin{array}{l}\text { no } \\
\text { fellures }\end{array}$ \\
\hline
\end{tabular}




\section{V.6.2 TFCX (3-8 Yeare)}

2. Plasna Disruptions. Improved wodels for vapor shlelding need to be Included in the computer codes used for predicting melting and vaporizacion effects caused by plasma disruptions. These predictiona need to be compared with electron beam experinental measurements to 1mprove tielr accuracy. The location, duration, and intenstty of the thermal quench portion of the disruption needs to be deflaed nore precisely.

3. Bolling Heat Transfer. Improved correlations are needed for predictIng the heat transfer coefficlent during forced convection subcooled nucleate bolling. The data should include multiple channel effects, swirl flow, and Internal fin effests for heat fluxes in the range of 100 to $2000 \mathrm{w} / \mathrm{cm}^{2}$.

4. Inelastic Behavior, Congtitutive laws for the Inelagtic behavior of candidate heat slak materials at elevated temperatures need to be developed to a.1 low wore accurate predictions of time-dependent stress changes due to pisstic deformation and thermal creep. Highest priority are the high strength/high thermal corductivity copper and molybdenum alloys. These constitutive laws should include cyclic effects (e.g., cyclic hardening) so that more accurate fatigue damage calculattons can be performed.

\section{V.6.3 INTOR}

5. Irraulation Effects to Thermal Properties. The decrease in thermal conductivity due to noutron 1rradiation needs to be measured for non-metallic high heat flux armor materials, in particular, SiC, TIC, Beo, and graphite.

6. Irradiation Effects to Mechanical Properties. The response of copper and molybdenum heat sink alloys to neutron damage needs to be measured; in particular, the change in gleld strength, ultimate strength, and swelling and creep behavior ate most important.

7. Simplified Inelastic Stress Codzs. Due to the complextty of performIng detalled finte elewent structutal analyses, thers is a need for simplifled inelastic stress analysis programs that can efficlently simulate the long-term response of simple geometrieg and boundary conditions to swelling and creep deformation. These codes would be useful for doing parametric design atudies and for evalusting the 1mpact of newly developed correlations for radiation damage effects. When tntegraced with models for fatigue, 
erosion, crack growth, etc., the package beconed a powerful tool for lifetiae predictions.

\section{V.6.4 DEMO/Comercla1}

8. Creep Crack Growth. The rate of crack growth for waterials at conant load and high temperature (1.e., creep crack growth) needs to be measured $f i t$ candidate heat sink materials, since this may be the lifel1miting dawage pechanism for long-pulse and steady-state fuslog reactors.

9. Fugion Design Code. A new atructural design code, simflar to the ASHE Boiler and Pressure Vessel Code, needs to be written specifically for fuston power reactors.

10. Corrosion. The long-term corrosive effects of bolling water and liquid lithium coolants on copper and molybdenum alloy heat sink materials needs to be addressed.

\section{V.7 Critical Issues}

\section{V.7.l Existing Machines}

No critical lasues were identified for exfsting machines with respect to thermomechanical response.

\section{V.7.2 Near Term (TFCX)}

1. Bond Integrity. The structural integrity of the attachment interface between the plasma side armor material and the actively cooled heat sink must be demongtrated. Th1s requires thermal fatigue testing of prototype components on ASURF and PMTF, generic component testing on ESURF and EBTF, bond strength and thermal conductance data, and 2-D finite element thermal and Btress analysis.

2. Melt Layer Stabilfty. Loss of the melt layer due to eddy current forces during a plagma disruption must be avolded to prevent excessive surface erosion. Laboratory expertments and computer slaulations mut be performed to assess the severity of this problem and to facllitate design changes that may eliminate the effect. 
3. Burnout. Catastrophic fallure of an actively cooled heat sink caused by burnout of the coolant channel nust be prevented. More accurate correlatlons for critical heat flux must be develuped for relevant conponent geonetrles to provide an adequate wargin of safety whthout belng overly conservative.

4. Patigue Crack Growth. Crack growth leading to a coolant leak or fallure of the plasme-side material nust be prevented. Basic data on fatigue crack growth rates in candidate materials and across interfaces is required for computer simulations. Thermal fatigue testing of intentionally flawed procotype components should be performed to verify the fracture mechanics analysis.

\section{V.7.3 ETR/INTOR}

5. Bond Integrity. Neutron radiation dezage will degrade the bond between armor and heat sink due to (1) differential swelling otress bulldup, (2) impurity transport to the interface, and (3) embrittlement. Long-term Irradiation must be performed in PFTF, EBR-II, and FMIT on bonded specimens to develop appropriate damage models that can be used in computer simulations of bond fallures.

6. Eroston. Surface erosion is a critical lifetime 1ssue that directly affects the thermomechanical response.

7. Embrittlement. Neutron-induced embrittlement of candidate high heat fItu materials must be understood to avold catastrophic fractures. Fracture toughness measurements on Irradlated specimens should be Integrated with a fracture mechantcs analysis to provide an adequate safety margin.

\section{V.7.4 DEMO/Commerc1al}

8. Creep/Fatigue. The interactions between creep and fatigue damage during qeucron 1rradiacion may accelerace crack growth rates and lead to premature fallure. More experimental data and modeling are required.

9. Creep Rupture. For long-pulse or steady-8tate fuston reactors, creep rupture may be the life-limiting fallure wode, espectally under the Influence of radiation damage. More experimental data and modeling are required. 
10. Swelling. Low owelling in-vessel aterisls anst be developed for long-term: applications because excessive deformationg may prevent easy removal for alntenance and repalr. 
1. Rohsenhow, W. M. and Harnett, J. P., "Handbook of Heat Transfer," McGrawH111 Co., 1973.

2. Abóou, M. A., et al., "Chapter VII, Impurity Control and First Wall Eng1neer1ng," FLE-INTOR/ICFW/82-17.

3. McFarI1n, D. J., et al., "Active Cooling System for the LLNL Mirror Fusion Source Test Facility," Third Toplcal Meeting on Fuston Reactor Materials, Albuquerque, NM, 1983.

4. Hatson, R. D., Peterson, R. R., Wolfer, W. G., "Lifetine Analysis of Fusion Reactor F1rst Wall Components," J. Pres. Ves. Tech., 105, Pp. 144152. 
CHAPTER VI

ELECTROMAGNETIC RESPONSE

Lead Author:

W. Wolfer (UW)

Contributors: 


\section{vI. ELECTROMAGNETIC RESPONSE}

\section{VI.1 Introduction to the Issues}

\section{VI.1.1 Eddy Currente during Normal and D1srupt1ve Plasma Behavior}

Eddy currents of significant magnitude are induced in the vacuum vegsel and all 1n-vessel components made of metals when the magnet: = flelds change, which are generated by surrounding colls and the plagma current. In tokamaks, such changes occur during plasma startup and shutdown, during discharge cleaning procedures, and during plasma disruptions. The induced eddy currents during plasma disruptions are by far-the greatest, and since unintentional disruptions take place wth a signifleant probability, they determine to a large degree the design requirements for the vacuum vessel, for in-vessel components, and even for external cotls.

The electrowignetfc response of high heat flux components to plasma disruptions cannot be considered in tsolation from the response of the eatire vacuum vessel, other in-vessel components, and the distuping plasma ituelf. The reason is that the eddy currents induced during a disruption in the various parts of the vessel are coupled by the mutual inductances and to the decaying plasma current Itself.

It $1_{\theta}$, therefore, inevitable that a global, and somewhat simplistic, eddy-current analysis encompassing the entire vacum vessel and its internal components wust precede any detalled analysis of the electromagnetic response of a high heat flux component ouch as a limiter. One of the central issues is then how to combine self-consistently the global with the deialled analysis. An equally important igsue is the coupling between the Induced eddy currents 1n the vacuum vessel and the decaytng plasma current. This coupling can greatly affect the wotion of the plaswa and the distribution of the energy deposition on high heat flux components during the disruption.

A plasma disruption $1 \mathrm{~s}$ characterized, from the point of view of 1 ts potential danage to the vessel components, by two phases: the threrral quench and the current decay phase. These phases way partlally or fully overlap, and the start and extent of each may vary according to the design of the fuston device. 
It has been assumed in recent design studies of future furion devices that the thermal quench period lasts sonewhere between a few mll1iseconds and $100 \mathrm{~ms}$, whereas the plasma current decay time 1s significantig longer(1-3). As a result, the heating and the chermonechanical response of a liniter 18 caused mainly by the thernal quench, and the eddy current heating is of minor fmportance. However, the melt layer that may form on the limiter Burface may be rendered unstable when the eddy current forces reach their maximum after the thermal quench.

The lack of a complete understanding of plasma discuptions as well as the anticipated strong coupling between Induced eddy currents and the plasma current decay makes it necessary to carefully examine in future development of high heat flux components the full consequences of electromagnetic effects. It is premature to rule out any of the effects to be discussed in the followIng based solely on present conceptions of tokamak reactors.

VI.1.2 Joule Heating by Eddy Currents

One of the consequences of plasma disruptfons and Induced eddy curreits is the volumetric heating of the vacuum vessel and other metallic in-vessel components. I is rate of heating is given by $j^{2} / \sigma$ per unit volume and per unte time, where $\sigma$ is the electrical conductivity and $f$ is the eddy surrent flux in the component under consideration. The Joule heating by the sddy currents $1 \mathrm{~s}$ accompanied by the heat flux from the thermal decay of the plasma during the disruption. Although the latter source of heating $1 \mathrm{~s}$ belleved to be greater on limiters, Joule heating is not necessarlly negligible even though it is deposited more unfformly into the vacuum vessel. The reason is to be found in the relatively. small skfn depth for rapld current decay tioles, $\tau_{c}$. If

$$
\kappa=1 / \mu \mathrm{O}
$$

Is the magnetic diffusivity of the metal used for the high heat flux component, o the electrical conductivity, and p the permeability, then the skin depth is defined as

$$
\delta=2 \sqrt{K T_{c}} .
$$


Table VI.1 11sts bath the magnetic diffusivity and the okin depth, $\delta$, for discuptions wth three different current decay times. For short decay times and good conductors, the penetration depth of both the magnet1t fleld perturbation and the eddy currents is less than the thickness of the component. Accordingly, the eddy current heating can be concentrated in a rather thin surface layer and may, therefore, contribute signiflcantly to the heating, melting, and evaporation of the 11miter surface.

\section{VI.1.3 Arcing}

Arcing is commonly observed in conjunction with plasiz disruptions, and two types must be distinguished.

Unipolar arcs occur between the plasma (acting as an anode) and he vacuum vessel as a result of the sheach potentfal. The causes for this type of arcing are noc well understood.

The second type of arcing may take place between electrically isolated sections of the vacuur ressel or of 11miters. In order to increase the resistance of an in-vessel component and reduce the overall eddy currents, tine components and the vacuum vessel are segmented. Intrrupting the $p$ th for eddy currents, however, cteates large voltage gaps with the potential for arc formation during disruptions. Preventing thls type of arcing requires a detalled analysis of the magnitude and distribution of eddy currents following a disruption.

VI.1.4 Induced Forces

The generation of eddy currente leads to very large forces in the vacuum vesse and 1n-vessel components. These Induced forces can be divided into two groups: one 1 s created by the interaction of eddy currents with the excernal static magnetic flelds, and one by the interaction of eddy curcents thenselves. The latter group $1 \mathrm{~s}$ of minor importance for the solid structures, but It may play a significan - role in the stability of melt layers formed during a disruption. The former group determines to a large extent the structural support for the vacuum vessel and all in-vessel components, and the electromagnetic forces represent, therefore, the major consequence of plasma disrup.. tion to the design of high heat flux components. The particular needs for the eddy current and force evaluation will be discussed at length in Section VI. 3 . 
Table VI.1

Magnetic Diffusivi ${ }^{*} y, K$, and Skin Depths, $\delta$, for a Few Metallic Materiala

\begin{tabular}{|l|c|c|c|c|}
\hline Metal & $\kappa\left(\mathrm{cm}^{2} / \mathrm{s}\right)^{*}$ & $100 \mathrm{\mu s}$ & $1 \mathrm{~ms}$ & $10 \mathrm{~ms}$ \\
\hline $\mathrm{Cu}$ & 126 & 0.22 & 0.71 & 2.2 \\
Al & 204 & 0.29 & 0.90 & 2.9 \\
AISI 304 & 5900 & 1.54 & 4.86 & 15.4 \\
W & 390 & 0.39 & 1.25 & 3.9 \\
\hline
\end{tabular}

*Based on electrical conductivities at room temperature 


\section{VI.2 Eddy Gurrent Codes}

\section{VI.2.1 Kethads for Evaluating Eddy Girrent}

In principle, eddy currents can be evaluated by oolving the Maxwell equations

$$
\text { Z. }
$$

subject to the constitutive laws

$$
\underset{\sim}{\mathrm{B}}=\underset{\sim}{\mathrm{H}}, \quad \underset{\sim}{\mathrm{J}}=\sigma \underset{\sim}{\mathrm{E}} .
$$

It is customary in eddy current problems to neglect the displacement currents, 1.e., $3 \mathrm{D} / \partial t=0$. This assumption can be made in a conducting medium if the frequency, $w$, of the electromagnetic field atisfies the condicton $1 / w \gg \varepsilon / \sigma$ and if the electron or charge carrier response time, $\tau$, to an electric field satisfies $\tau_{e}=10^{-14}$ seconds. Hence, for all frequenctes up to the infrared spectrum, the assumption $\partial D / \partial t=0$ is justified.

For the solution of the above equalions, a vector potential $\underset{\sim}{\mathrm{A}}$ and $a$ scalar potential $\phi$ are introduced such that

$$
\underset{\sim}{B}=\underset{\sim}{\nabla} \times \underset{\sim}{A}, \quad \underset{\sim}{E}=-\underset{\sim}{A}-\underset{\sim}{\nabla} \phi
$$

thereby sacisfying two of the Maxwell equations, 1.e., $\underset{\sim}{\nabla \cdot B}=0$, and $\underset{\sim}{\nabla} \underset{\sim}{E}=-\underset{\sim}{B} . \quad$ The third equation together wth $\underset{\sim}{\mathrm{B}}=\mu \underset{\sim}{\mathrm{H}}$ leads to

$$
\left.\nabla^{2} \underset{\sim}{A}-\sigma \underset{\sim}{\Phi}-\underset{\sim}{\nabla} \underset{\sim}{\nabla} \cdot \underset{\sim}{A}\right)+(\underset{\sim}{\nabla A}) \cdot(\underset{\sim}{\nabla} \ln \mu)-(\underset{\sim}{\nabla} \ln \mu) \cdot(\underset{\sim}{\nabla A})=\sigma \mu \underset{\sim}{\nabla} \phi
$$

whereas the continuity equation $\underset{\sim}{\nabla . J}=0$ results in

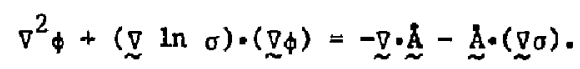

For non-ferromagnetic materlals $(\nu=$ const.) and the Coulomb gauge $\underset{\sim}{\nabla}+\underset{\sim}{A}=0$, these equations simplify to 


$$
\begin{aligned}
& \nabla^{2} \underset{\sim}{A}-\sigma \mu \underset{\sim}{\mathcal{A}}=\sigma \mu \nabla_{\phi} \\
& \nabla_{\phi}^{2}+(\underset{\sim}{\nabla} \text { ln } \sigma) \cdot(\underset{\sim}{\phi})=-\sigma \underset{\sim}{\not}(\underset{\sim}{\nabla} \ln \sigma) .
\end{aligned}
$$

None of the avallable eddy current codes lo presently capable of oolving Fiqs, (4a) and (5a). Instead, $\sigma$ and $\mu$ must be constants In a limited numbe $z$ reglons for some codes, or constants through the entire component for most codes. In both cases, it 1 s then posstble to set $\phi \equiv 0$. Both the strong 1 "temperature dependence of $\sigma$ and the composite nature of high heat flux compo- nents makes it necessary to develap new eddy curreni codes for variable conductivitles and 3-D geometries.

\section{VI.2.2 2-D Codes and 3-D Codes}

Whth regard to the electromagnetic forces exerted on the first wall and the in-vessel components, the eddy current distribution through the wall thlckness: is of little concern. As a result, the assumption can be made that the wall is a shell structure and the ejdy curzents are uniform across the wall, reducing the eddy current pattern to a two-dimenstonal one on the surface of a shell.

A survey of eddy current codes by Lari and Turner (4) indicates that a large varlety of codes exists for the 2-D analysis of eddy currents in rectangular and cylindrical geometrles. The list, shown In Table VI.2, of 3-D eddy current codes is significantly shorter. The asterlak next to the code name or number indicates those codes which allow for continuous spatial variation of the electrical conductivity.

\section{VI.3 Coupling of Eddy Currents to Thermomechanlcal Regponse}

The three responses of an in-veselel component to plasma disruptions, namely heating, electromagnetic loading, and translent stresses are fnterrelated as Indicated in FIg. VI.1. A particular Intricate foedback between heating and eddy current distribution exists through the strang temperature dependence of the electical conductivity and the Joule heating. For this reason, an accurate 3-D evaluation of the eddy current distribution with depth lo considered to be Important. 
Table VI.2. Rectangular Geometry Eddy Current Computer Programs

\begin{tabular}{|c|c|c|c|c|c|c|}
\hline Dimensions & & & $\begin{array}{l}\text { Geonetry } \\
\text { Field } \\
\text { Current }\end{array}$ & $\begin{array}{ll}2 & D(X-Y) \\
2 & D \\
1 & D\end{array}$ & & \\
\hline Steel B-Ul Relationship & \multicolumn{2}{|c|}{ None } & \multicolumn{2}{|c|}{ Linear } & \multicolumn{2}{|c|}{ Nonlinear } \\
\hline $\begin{array}{l}\text { Changini Magnetic Field or } \\
\text { Changing Source Currents }\end{array}$ & $\begin{array}{l}\text { Steady } \\
\text { State }\end{array}$ & Transient & $\begin{array}{l}\text { Steady } \\
\text { State }\end{array}$ & Transient & $\begin{array}{l}\text { Steady } \\
\text { State }\end{array}$ & Transient \\
\hline $\begin{array}{l}\text { Finite Difference } \\
\text { Flnite Elements } \\
\text { Varlational Formulation }\end{array}$ & $\begin{array}{l}\text { HYBRID-5 } \\
\text { AOSMAG-18* } \\
\text { TRIDIF-19 } \\
\text { COMPELL-22 } \\
\text { ELUX2D-44 }\end{array}$ & 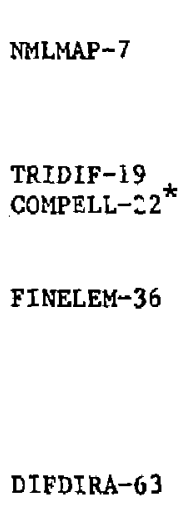 & $\begin{array}{l}\text { HYBRID-5 } \\
\text { PE2D-8 } \\
\text { NONAME-14 } \\
\text { AOSMAG-18* } \\
\text { TRIDIF-19 } \\
\text { COMPELL-22 } \\
\text { NONAME-23 } \\
\text { SKIN1-27 } \\
\text { FLUX2D-44 } \\
\text { PHMES-48 } \\
\text { MAGNET11-54 } \\
\text { CSWEDDY-60 }\end{array}$ & $\begin{array}{l}\text { NMLMAP-7 } \\
\text { PE2D-B } \\
\text { TRIDIF-19 } \\
\text { COMPELL-22 } \\
\text { NONAME-23 } \\
\text { FINELEM-36 }\end{array}$ & $\begin{array}{l}\text { HYBRID-5 } \\
\text { TRIDIF-19 } \\
\text { COMPELL-22* } \\
\text { NONAME-23 } \\
\text { PHMES-48 } \\
\text { SCEDDY }-52\end{array}$ & $\begin{array}{l}\text { MMLMAP-7 } \\
\text { PE2D-8 } \\
\text { TRIDIF-19 } \\
\text { COMPELL }-22^{*} \\
\text { NONAME-23 }\end{array}$ \\
\hline Integral Equation Method & $\begin{array}{l}\text { HYBRID-5 } \\
\text { NONAME-20 }\end{array}$ & INTEQ-38 & $\begin{array}{l}\text { HYBRID-5 } \\
\text { NONAME-20 }\end{array}$ & INTEQ-38 & HYBRID -5 & \\
\hline $\begin{array}{l}\text { Other, Open Body, Elements } \\
\text { Integradifferential }\end{array}$ & AOSMAG-18 & & $\begin{array}{l}\text { AOSMAG-18 } \\
\text { SKINL }-27 \\
\text { INTEQA-38 }\end{array}$ & & & \\
\hline
\end{tabular}

${ }^{\star}$ Codes with capabilities for spatial variation of the electrical conductivity 


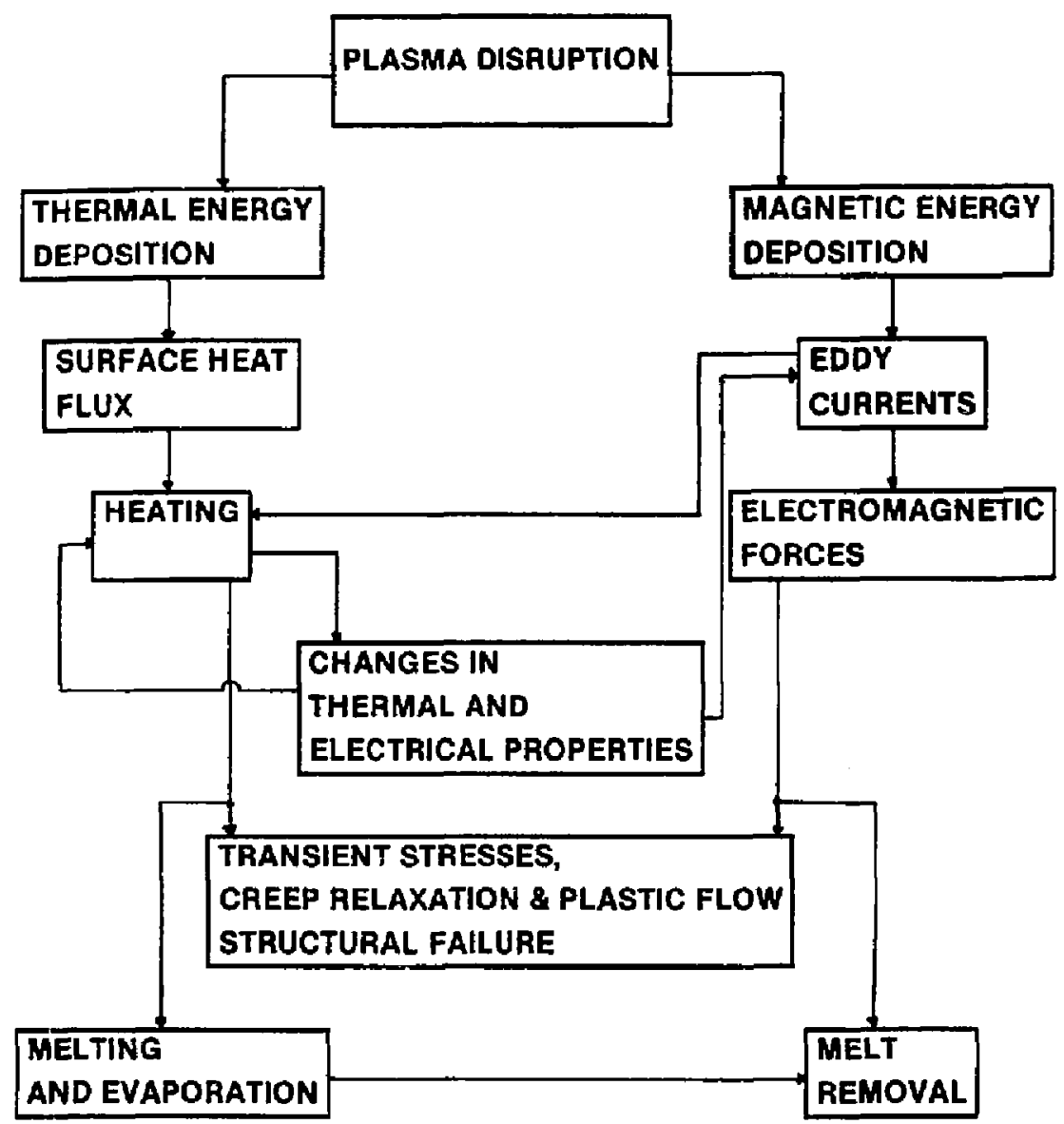

Figure VI.1. Interrelation of the three responses (heating, electromagnetic loading, and transient stresses) of an in-vessel component to plasma disruptions. 


\section{VI.3.1 Joule Heating}

The strong coupling between therwal response and eddy currents becomes obvioug when considering the heat conduction equation

$$
\underset{\sim}{\nabla}[K(T) \underset{\sim}{\nabla}]-c(T) t=-\sigma(T)\left(\underset{\sim}{A}+V_{\phi}\right)^{2}
$$

where $k(T), c(T)$, and $\sigma(T)$ are the thermal conductivity, the specific heat, and the electrical conductivicy, respectively. Here, the Joule beating is first expressed in terms of the electric fleld and then in terms of the vector and scalar potentials. For a homogeneous material, the material parameters become spatially dependent by virtue of their temperature dependence. In composite materials such as coated metals, an addftional spatial dependence exists by design.

The temperature dependence of $\sigma$ requires that the electromagnetic fleld equations (4a) and (5a) be solved simultaneously with the heat conduction problem if Joule heating contributes to the thermal response of the 1n-vessel components to disruptions. None of the present eddy current codes allows for such a coupling to the thermel response.

\section{VI.3.2 Electromagnet 1c FeEse Distribution 1n Solid Structures}

Even though the eddy currents produce a spatially distributed body force, $J x \underset{\sim}{*}$, per unit volume, it is not always essenitis for the otress analysis of solid in-vessel components to have the precise electromagnetfc force distribution throughout the components. For example, if atcachment bolts for a limiter need to be designed, It suffices to eyaluate the overall electromagnetic forces on the limiter but not the detalled force distribution. Eddy current codes for 2-D analysis are then adequate.

On the other hand, when considering eddy current forces of components plated with metalilc coatings, the depth distribution of eddy currents must be evaluated. It appears then that different analysis tools are required dependIng on the particular application.

The eddy current forces can induce large amplitudes of vibrations in thin-walled or slender structures. The motion of the conducting structure produces, in turn, additional eddy currents of magnicude ov $x \underset{\sim}{\mathrm{B}}$, where $\underset{\sim}{\mathrm{i}}$ is 
the veloctty of the material point. These additional eddy currents caio produce a significant damping of the vibration and thereby reduce the amplitude of the dynamic atresses (5). This beneficial effect may, however, be offaet by the additional Joule heating which Increases the transient thermal stresses. If this feedback inco the thermal response is indeed significant, the electromagnetic, elastodynamic, and thermal analysis must all be carried out simultaneous1y.

\section{VI.3.3 Electromagnetic Force Distribution in Melt Layers}

Severe plasma disruption may lead to surface melting of in-vessel compo-. nents. However, for the short duration of the melt layer, gravitational forces are usually not sufficient to remove the thin melt layer. Therefore, the eddy current forces are of major concern(6). To correctly evaluate the distribution of these forces, a 3-D analysis as outlined above is required caking into account the depth- and time-dependent materlals properties. For the analysis of the melt layer stablilty, it is also important to consider the self-inceraction of the eddy currents in addition to the interaction with the external magnetic field.

\section{VI.4 Conclustons and Recommendations}

Eddy currents and induced electromagnetic forces Impose severe design requirements on ingh heat flux components of both near-term and future fusion reactors. It 1s, therefore, absolutely essential to have adequate tools avallable to analyze and predict correctly the eddy current distribution and the associated heating and the forces on any In-vessil component. The zonsequences of a faulty design could be disastrous. Furtherwore, optimal designs can only be achieved with the correct tools.

The major 1ssues which artse in the analysis and evaluation of plasma disruptions and their consequences are as follows:

a) The induced eddy currents react back on the decaying plasma cur-rent. This affects the motion of the plasms and the subsequent energy ceposition on in-vessel components. Such coupling or feedback has not been adequately treated in previous desfgn atudies, 
b) The nagnitude, direction, duration, and distribution of the electromagnetic forces have been evaluated for bimplified geometries of In-vessel components but not for real geometries.

c) High heat flux components in future devices and reactors will most likely be heterogeneous and have complex geometries with grooves, cut 8 , and convoluted coolant channels.

d) Local arcing and erosion can occur between parts or segments of a high heat flux component which are separated by a high resistivity path.

e) Nelt layers which form in response to the thermal quench can be removed by the eddy current forces.

The adequacy of present tools to address the above 1ssues $1 \mathrm{~s}$ judged somewhat differently by varlous researchers $(7)$. Whereas syetem designers consider present analysis tools adequate, but stress the urgent need for vigorously addressing lssue (a), matertals analyste and component designers consider a 3-D analysis capability absolutely essential to address the 1ssues (b) through (e).

This difference In emphasis is a reflection of two different but coupled objectives and the best strategles to achleve them. A global analysis of the eddy currents must by necessity seek an approximate model for the entire first wall and the orher 1n-vessel components. For this reason, eddy current codes are 1padequate to address the 1ssues (a) through (e). For the deatgn of such critical components as, for example, an actively cooled limiter covered with tyles of beryllium, it ts essential to develop a 3-D analysis capability for eddy currents, Joule heating, and electromagnetlc forces.

The following takks are, therefore, recommended with highest priority:

- Develop a 3-D eddy current code for high heat flux components which incorporate fn theit design different materials with temperaturedependent conductivities.

- Integrate th1s code with a general purpose, fintte element structural analygis code and incorporate magnetic dacping.

- Coordinate this development with a corresposding one fin plasma engineering which deals with the plasma behavior in distuptions and with the global eddy cutrent analysis. 
- Conduct benchuaric tests 10 FELIX and/or existing fusion devices to confirm design code results.

- Conduct stmulation experimenta on melt layer formation and their Btability under electromagnetfc forces.

All of the above efforts represent essentlal tasks which are necessary ir. order to develop rellable high heat flux conponents. As supporting efforts, it is recommended to:

- Test prototype componenta 1a FELIX.

- Evaluate the need for a coupled thermal and eddy current analgsis.

- Investigate the coupling between magnetic damping, Joule heating, and electromagnetic forces. 
1. INTOR, Phase 0, LAEA, VHenna, 1980 .

2. "The Fublon Englneering Device," DOE Report No, DOE/TK-11600, 1981.

3. c. C. Baker, et al., "STARPIBE - A Comercial Tokanak Fusion Power P1ant Study," Argonne Nat LonaI Laboratory Report No. ANL/FPP-80-1, 1980 .

4. R. J. Lar1 and L. R. Turner, "Survey of Eddy Current Programa," CoMPUMAGChfcago, IEEE Trans., Magnetics, Vol. MaG18, 1982.

5. J. Blalek, D. Welssenberger, M. Ulrickson, J. Cecch1, Modeling the Coupling of Magnetodynamies and Elastomechanics in Structural Analysis," Tenth IEEE Symp. on Engr. Problems of Fuslon Research, Philadelphia, PA, 1983.

6. W. G. Wolfer and A. Hassane1n, "On Melt Lager Stabllity Following a Plasma Disruption," J. Nuc1. MatIs., $111 \& 112,560$, 1982.

7. Based on discussions with J. Kurray, L. E. Turner, M. Ulrickson, D. Welssenberger, and W. D. Watson. 
CHAPTER VII

HIGH HEAT FLUX CONPONENT TEST FACILITIES

Lead Author:

J. Gordon (TRW)

Contributors:

D. Goebel (UCLi)

R. Mattas (ANL)

S. Milora (ORNL)

R. MoIr (LLNL)

E. Opperman (HEDL) 


\section{vI1. HIGH HEAT FLUK COHPONEWI TEST PACILITLES}

There are several facllitieg already in operation or under conacruction that are dedicated to high heat flux compenent testing or that can be used for th1s purpose. Some of these facilitles are apecifically part of and supported by the High Heat Flux Component Development Program. Other facilities are owned by different parts of the fusion program but cas be used for component testing. There are three categorfes of factlities that can be considered for high heat flux component testing. The first of these are dedicated facilities or those that could be dedicated to high heat flux testing; ten such facilities have been 1dentified. Seven of thdese are operational: the ESURF, ASURF and ISURF facilities at hestinghoube, the Sandia-Albuquerque e-beam factlity, an fon-beam facility at TRW, the PISCES 1on-beam facility at UCTA and the direct converter test stand at LLML. The Plasma Materials Test Factlity (PMTF) at Sand1a-Albuquerque is under construction. An electron-beam fac1lity at HEDL is being modifled for use in a hot cell to test irradlated components. A magnetic mirror facility designated ICTF (Impurity Control Test Factlity) is being constdered by ANL for high heat flux component and impurity control testing. The ICTF vould potentially use some components from FELIX (Fusion Electromagnetic Induction Experiment). The characteriatics of these factlities are described in Tables VII-1 and VII-2. The secont type of facility that can be used for high heat flux testing is the neurral beam or RF test stand. Althugh component testing is not the p=imary function of these facillties, they have extensive capabilities that can be used for the high heat flux program. The neutral beam stands have the capability for both high snergy fon and neutral bombardment of surfaces. Three large test stands are sperational at LBL and ORNL. The capabilities of the LBL neutral beam test stand, the Med1um Energy Test Faclilty and the High Power Test Fac1lity at ORNL are listed in Table VII-3. The RF Test Fac1l1ty (RFTF) at ORNL is in the planning stage. Shile 1ts primary purpose 1s testing RF component and system performance, it should be sultable for testing eroston of plasma side components. The capabilities of the RFTF are also given in Table VII-3. The third type of facllity that has high heat flux test capability is a fusion device 1trelf. These have not been included in the tabulation of facllity characteribtics because of limited avallability for testing and because the components for a fublon device generally wust be tested elsechere before being used in the machine, However, these faclitites should be used for 
Table VII-1. Dedicated Electron Test Facilities

\begin{tabular}{|c|c|c|c|c|}
\hline & ESURF & ASURF & Sandila & HEDL \\
\hline Particle Type & electron & electron & electron & electron \\
\hline Energy (keV) & 150 & 16 & 30 & $12-25$ \\
\hline Current (A) & $.005-.33$ & 6 & 1 & $2 \cdot 5-5$ \\
\hline Power (kW) & 36 & 64 & 30 & 60 \\
\hline Peak Power (kW) & 50 & 100 & - & - \\
\hline Pulse Length (s) & $\mathrm{Ig}-\mathrm{CW}$ & mg-CW & mg-CW & $.5-\mathrm{CW}$ \\
\hline Target Area $\left(\mathrm{cm}^{2}\right)$ & $.01-500$ & $i 00-10,000$ & $.01-100$ & $1-200$ \\
\hline Heat Flux $\left(\mathrm{kw} / \mathrm{cm}^{2}\right)$ & up to 5,000 & up to 2,000 & $.3-3,000$ & $\cdot 3-60$ \\
\hline Coclant & water & water & water & water \\
\hline Pressure (psi) & 1000 & 2200 & 300 & 120 \\
\hline Flow Rate (gpm) & 20 & 60 & 50 & 20 \\
\hline Heat Re:noval (kH) & 100 & 2000 & 30 & 60 \\
\hline Status & $\begin{array}{c}\text { operational } \\
\text { being } \\
\text { phased out }\end{array}$ & operational & operational & $\begin{array}{c}\text { e-beam } \\
\text { operational } \\
\text { being modified } \\
\text { for hot cell }\end{array}$ \\
\hline Under HHFCDP & no & yes & yes & yes \\
\hline
\end{tabular}


Table VII-2. Dedicated Ion Test Fecilities

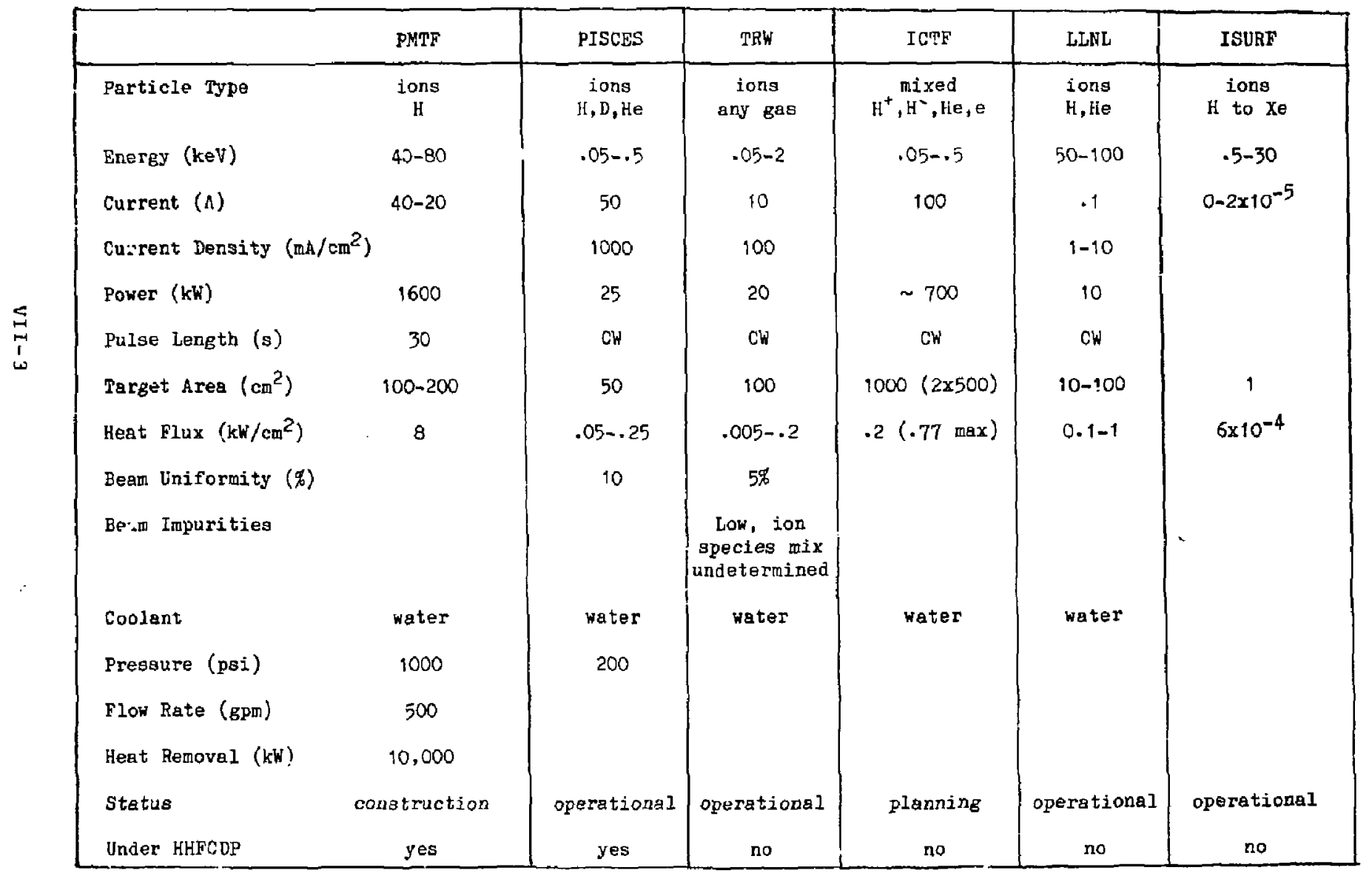


Table VII-3. Neutral Beam and RF Test Stand Characteristics

\begin{tabular}{|c|c|c|c|c|}
\hline & LBL & $\begin{array}{l}\text { ORNL } \\
\text { LETTF }\end{array}$ & $\begin{array}{l}\text { ORNL } \\
\text { HPTP }\end{array}$ & $\begin{array}{l}\text { ORNL } \\
\text { RPTF }\end{array}$ \\
\hline Particle Type & $\begin{array}{l}\text { iong } \\
\mathrm{H}, \mathrm{D}\end{array}$ & $\begin{array}{c}\text { iors } \\
\mathrm{H}\end{array}$ & $\begin{array}{c}\text { ions } \\
\mathrm{H}\end{array}$ & $\mathrm{H}^{+}, \mathrm{D}^{+}, \mathrm{He}^{+}, \mathrm{e}$ \\
\hline Energy (keV) & $40-120$ & 80 & 120 & $\sim 0.01$ \\
\hline Current (A) & 50 & 60 & 30 & \\
\hline Current Density $\left(\mathrm{mA} / \mathrm{cm}^{2}\right)$ & $<100$ & 240 & 250 & \\
\hline Power (kW) & & 4000 & 3600 & 1000 \\
\hline Pulse Length (s) & $<30$ & 30 & 10 & $\mathrm{CW}$ \\
\hline Duty Cycle (s) & 300 & 150 & 50 & \\
\hline Target Area $\left(\mathrm{cm}^{2}\right)$ & & 1000 & 100 & 3000 \\
\hline Heat Flcx $\left(\mathrm{kW} / \mathrm{cm}^{2}\right)$ & $\sim 2$ & 530 & $\leqslant 50$ & 0.4 \\
\hline Coolant & water & water & water & water \\
\hline Pressure (psi) & & 250 & 250 & 250 \\
\hline Flok Rate (gPm) & & 1000 & 1000 & $>1200$ \\
\hline Heat Removal (kW) & & $>4000$ & $>6000$ & $>1000$ \\
\hline Status & operationel & operational & operational & planned \\
\hline Under HHFCDP & no & no & no & no \\
\hline
\end{tabular}


confirmation tesing, when posstble, because they almulate or mateh the actual. hostlle environment.

All the dedicated electron beam facllities have some bimilar characteristica. All are scanned, efther raster or line scan. Thus, very high heat fluxes may be obtained by a preprogrammed scan pattern that limits the ares. Asurf is the only facility capable of testing the first wall of a water-cooled commercial reactor because of 1 ts high pressure coolant loop. However, the 250 to $300 \mathrm{psi}$ that is avallable is wast other facilftes is sufficlent to test 1imiters, divertors, beam dumps and other components that are water cooled without attempting to get high qualify heat. The other facilities could be used for these low pressure componente. The direct converter plates and halo scraper for the Mirror Advanced Reactor Study (MARS) power plant operate with coolant pressure above $2000 \mathrm{psi}$ and could only be tested in ASURF because of their high pressure. Planned, but not yet approved, upgrades for ASURF Include an Increage In the total beam power to 1 MW, Incorporation of liquid lithlum and/or hellum cooling loors, and the addition of a pulsed electron gun that would be used to simulate disruption heat loads over areas of about $10 \mathrm{~cm}^{2}$. ASURF has raster speed of $5 \times 10^{4} \mathrm{~cm} / \mathrm{s}$ while that of ESURF is $4 \times 10^{5} \mathrm{~cm} / \mathrm{s}$. ESURF has some disruption simulation capability with a beam rise time of about $20 \mu s$ and a dwell time from 1 to 110 ms. The HEDL test facility will be in a hot cell. Its unique function would be to test components that have been subjected to neutron damage in a zeactor. This sequential damage is the only mechanism to test in-vessel components for an ETR. The limit on component size is deteratned by fission reactor test volumes at this time. It is expected that multipie components would fill the e-beam facility test volume. The principal obfection to electron beam facilities is that most components are primarily subject to ton damage; thus, the true environment is not being simulated. Ore exception is the tandem mirror direct converter plates which are primarily subject to energetlc electron bombardment because $?$ lons are lnduced to leave the plasma radially by drift pumping.

The dedicated ton facilities fall into two groups. The PMTF is designed to test moderate sized components with ion-induced heat fluxes at sufficlently h1gh levels to simulate steady-state component operation in takamaks and mirrors. Because lons are used, the envirunment ts close to that of a fusion 
device. The Ion energy is a good matei for neutral beamline components, beam dumps, regions of high charge exchange flux from neutral beams, and wirror end cell components. However, the energy is elgaificantly higher than the edge temperature of a tokamak. The first phase of the PMTF has the highest power of all the planned and existing facilitles. It is planned to add a second source in the future and increase the facflity power by more than a factor of two.

The other facilfties, PISCES, TRH, ICTF, ISURF and LLNL are principally to pei form physics, materials and engineering experiments. Spectfic uses are ecosion studies lncluding sputtering, bligtering, and redeposition, fon recycling, gas conductances, and limiter/diverter pumping effictencles. They are typically better controlled and diagnosed than the larger facllity. ICTF, being essentially a confinement device where all other factlities are accelerators, w1ll have a mixed spectrum of lons, neutrals and electrons. Most of the energy is deposited by the 1ons. Testing $1 \mathrm{f}^{\mathrm{t}}$ this mixed spectrum, which is typlcal of wany fusion device components, may be of significant value where synergistic effects are 1mportant. The LLM fac1lity has operated for many Individual runs of several hours each with an accumulated nun time of 80 hours on a tungsten collector. It has a rather low operating expense. The TRW facllity has been run for graphite sputtering with continuous operating times in excess of 4 hours and controllable ion energles between $50 \mathrm{eV}$ and 2 keV. The current density depends on oscillator power and is now ifmited to about $100 \mathrm{~mA} / \mathrm{cm}^{2}$ and could reach $500 \mathrm{~mA} / \mathrm{cm}^{2}$. The ISURF is an ton factlity jofutly operated by Westinghouse and Penn State for low energy bopbardment of small sampies.

Westinghouse is planning to combine the ISURF and ESURF facilities, that are located in the same laboratory, through the cooling loop, power supplies and data acquisition system and adding an electron gun to ISURF for simultaneous irradiations. A simulation of combined lon surface interactions and electron surface heatirg may now be accompilshed by rotation of specimens fn ISURF and ESURF.

The In-situ diagnostics available at these facilities are as important part of testing. PISCES has, or ls planned to have by FY 1985 plasma probes to measure $n_{e}$ and $T_{e}$, residr.. gas analyer, calorfmeter, ExB wass analyzer, $H, \alpha$ interferometer, microwave interferometer, and an energy an; lyzer. The TRW 
facllity has an opticai pyrometer, thermocouples, a residual gas analyzer, fon current monitor, Ion energy measurement, and source power monttor. The HEDL factlity is planned to include pyrometers, thermocouples and optical viewing In addition to electron beam monttors. Identical capabilities are avaflable ut Sandia and Westinghouse. 
CHAPTER VIII

INSTRUMENTATION AND CONTROL

Lead Author:

J. Easoz (Westinghouse)

Cont II butors :

J. Baugr (GA)

J. CecchI (PPPL)

A. Goldner (LLML)

J. Halnes (MDAC/FEDC)

R. McKeever (Westinghouse)

R. Motr (LLNL) 


\section{INS'TRUNENTATION AND CONTROL}

\section{VIII.1 Introduction}

The Instrumentation and control (I\&C) of HHF components for magnet1c fusion devices is an area in the fusion effort which has received ralatively little attention to date. This state of neglect is somewhat underacandable in the context of the overwhelming physics problems associated sith , program strucfling to demonstrate scientific feasibility. I\&C efforta in the fusion program have primarily focused on generating, maintaining, and characterizing millisecond bursts of plasma, a heavily diagnostic program which, by nature of the shortness of the event, is very limiced with respect to closed loop feedback control features. Also due to these short pulse lengths, there has been no need for active cooling of thege components. Th1s has ellminated the need for a major portion of the Isc which will be required for future HHF components. The lack of experience with operating devices which produce significant loads on these control features with respect to both component perfotmance and other device systems (1.e., the data base required to develop proper control algorfthn; is insufficient at this time.

W1th the next phase of device operation (present machines and their upgrades), it wil become important to begin to address IfC of HHF components. The severity of impact on device operation of the fallure of any actively cooled atructure wichin the plasma chamber dictaces that the performance of these HHF components will need to be continuously monitored. Although signiflcant contrcl will probably not be utilized on these devices, the increased use of Instrumentation will allow the data base generation fur control algorithms to praceed and should provide component designers with important source parameters. The devices presently in the conceptual design phase should fnclude the abllity to test some of these control schemes so that a fe:d of these techniques can be incorporated into the standard control logic of devices such as ETR and DEMO.

The next few sectiong discuss the I6C which are, and will be, required to assure proper HHF component performance and compatibility with the whole fusion device. The presently utilized and potential techniques and the environmental constraints on the use of these techniques will be discussed. Plnally, conclusions and recommendations with respect to the present use and future development of HHP component ISC are presented. 
VIII.2 Measurement Requirementa

Measurements are required on HHE cowponents for primarily two reasons: 1) to monitor the performance of the conponent from a reliability standpoint and 2) to monitor key parameters which determine whether the component 1s operating in a mode which 18 compatible whth operation of the fusion device. Measurements made for elther of these two reasons can provide control input to a feedback loop or device operator or can aimply provide data which fs used as Input to the component or device development/design process. Table VIII-1 glves spectific examples of megsurements which will be required in the evolution to a commerclal reactor. It is expected that most measurements wil be required during the development stages and $t n$ off-1ine development/test devices. The vartety of measurements requited w11 gradually decrease as the components are 1mplemented in the devices and the devices near commercialization, with the most critlcal needs surviving the development process. The next two sections describe bowe of the required measurements for HHF components with respect to performance/reliability monftoring and device compatibility. Teciniques for performing these measurements, also listed in Table VIII-l, will be discussed in Section VIII.5.

VIII.2.1 Component Performance/Rellability

Since the main concern in the design of HHF components is the ability to withstand the high heat and particle loads in a fusion device environment, the performance and reliability measurements would tend to provide measures of the chermomechantcal and thermal-hydraulic response of the HHF component. The primary categories of Table VIII-1 which include these measurements are temperature, Btrain/dfsplacement, and coolant properties. During operation in the actual fusion device, measurements of surface temperature, surface efosion (1rcluding clad/coeting integrity), and seformation or cracking of the component wich may indicate imminent component fallure w11 probably be 1mportant to perform. The coolant temperatire (especially at inlet and outlet of the heated section), pressure urop, inlet (or outlet) pressure and flow rate will also be Important vartoles to monitor durlng operacion. Through these measurewents, one slıould be able to get a reasonable plcture of how the component ls performing. 
Table VIII. 1

Measurement Requirements and Potential Techniques for HHF Components

\begin{tabular}{|c|c|c|}
\hline $\begin{array}{l}\text { General Parameter } \\
\text { Category }\end{array}$ & $\begin{array}{l}\text { Potential Measurement } \\
\text { Techniques }\end{array}$ & $\begin{array}{l}\text { Examples of Spectfic } \\
\text { Heasurement Requirements }\end{array}$ \\
\hline Tenperature & $\begin{array}{l}\text { - Thermocouples } \\
\text { - Resistance temperature detectors } \\
\text { Infra-red pyroweters } \\
\text { - Fluoroptics } \\
\text { - Acoustic/sonic (gas temp.) }\end{array}$ & $\begin{array}{l}\text { - Surface tempetatures } \\
\text { - Heat sink/coolant temperatures } \\
\text { - Heat transfer rates } \\
\text { - Discuption characterization } \\
\text { - Crittcal heat flux (burnout) }\end{array}$ \\
\hline $\begin{array}{l}\text { Strain/Streas/ } \\
\text { Displacement }\end{array}$ & 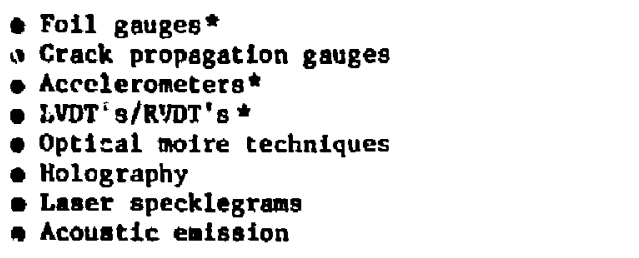 & $\begin{array}{l}\text { - Imminent cooponent fallure (1.e., surface } \\
\text { strain/crackIng) } \\
\text { - Warpage/buckling/deformation } \\
\text { - Erosion } \\
\text { - Vibration } \\
\text { - Component stress and otress distributiona }\end{array}$ \\
\hline Surface Conditiona & 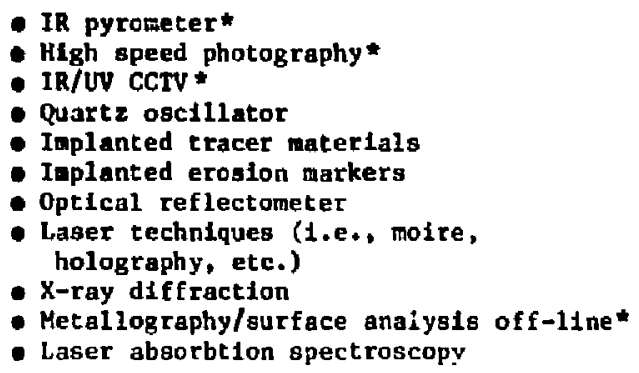 & $\begin{array}{l}\text { - Surface erosion rate/distribution } \\
\text { - Redeposition rate/diatribution } \\
\text { - Surface nelting detection } \\
\text { - Surface temperature } \\
\text { - Bond Integrity } \\
\text { - Cogting 1ntegrity } \\
\text { - Metallurglcai responge } \\
\text { - Internal coolant channel erosion/corrosion }\end{array}$ \\
\hline $\begin{array}{l}\text { Electrical/Magnetic } \\
\text { Paraneters }\end{array}$ & $\begin{array}{l}\text { - Hall effect gaussmeter } \\
\text { - Eddy current detectors } \\
\text { - Floating potential measurements* }\end{array}$ & $\begin{array}{l}\text { - Plasma position } \\
\text { - Disruption character izat lon } \\
\text { - E-M fleld measurements at component }\end{array}$ \\
\hline
\end{tabular}


Table VIII.1 (contd.)

\begin{tabular}{|c|c|c|}
\hline $\begin{array}{l}\text { General Parameter } \\
\text { Catepory }\end{array}$ & $\begin{array}{l}\text { Potent Lal Measurement } \\
\text { Techniqurs }\end{array}$ & $\begin{array}{l}\text { Examples of Spectfic } \\
\text { Measurement Requirtments }\end{array}$ \\
\hline Coolant Properties & 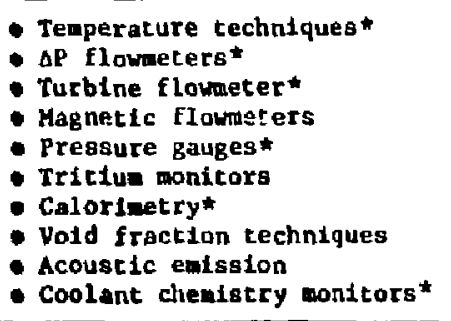 & $\begin{array}{l}\text { - Coolant leaks } \\
\text { - Critical heat flux (burnout) } \\
\text { - Two-phase flow characterization } \\
\text { - Heat transfer coefficient }\end{array}$ \\
\hline Vecuum & $\begin{array}{l}\text { - Vacuun gauges" } \\
\text { - Residual gas analyzers" } \\
\text { - Tracar gafes }\end{array}$ & $\begin{array}{l}\text { - Coolant leaks } \\
\text { Pump limiter/divertor perforance }\end{array}$ \\
\hline Power & $\begin{array}{l}\text { - Heat flux monitors } \\
\text { - Calorinetry* } \\
\text { - Radiat ion detector" } \\
\text { - Bolodeters* } \\
\text { - Thermocouples" } \\
\text { - IR detectors" }\end{array}$ & 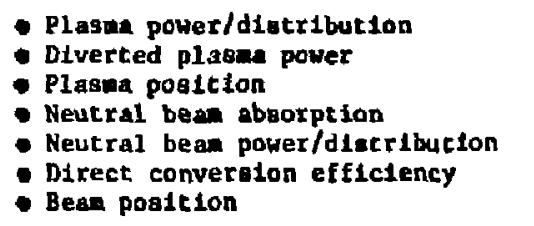 \\
\hline
\end{tabular}

*Presently being uned on exloting fuslon devices. 
Additional measuremente which include internal tenperatures of the component, critical heat flux measurements, two-phase flow characterization paraneters, heat trangfer rated, and gtregs distributions wili be required during component developaent fn off-IIne test fec1litles. Th1s type of 1aformation gives the designers a data base and proof tegt results from witch to base their final designs but will probably not require mesurewent in the device if sufficfent development has preceded the cosponent 1nstallation. Information on cycilc fatigue, vibration, flow instabilities, coolant channel erosion, and clad or coating survivability can also be provided by off-line test facilities for prototypicaliy sized HHF components but should not require implementation in the fusion device.

\section{ViII.2.2 Device Compatibility}

Compatibility of a HHF component with the overall fusion device is achieved when the component successfully performs the function for which 1 t was designed (f.e., divertor removeg impurities, direct convertor blows down and collects energetic particles and converts to electricai energy), performs :he function within the Intended design window, and produces no unexpected and undesirable effects on the device opericion. In addftion, to address whether the component is performing within the intended design window, determiration of the source parameters (1.e., plasma power/distribution) under which the component is operating should be made.

Measurements in all categories of Table vIII-I might be required to determine how well the HHF component is performing 1 ts function. Since these measurements are intended to provide information on how the component interacts with the fuston device, it is expected that all these measurements would be done during device operation and not in off-ifne test facilities.

Measurements such as surface temperature and eroston rate and distribution are just as desirable here as they are for examining component rellab111ty. In addition, redeposition rates and distributions, detection af surfuce weIting, and characterization of distuptions (frequency, magnitude, durition, and location) would be deolrable aeasurewents. Performance characte:istics for pump lialters and divecrors can be weasured to some extent $t$ : : ough th: vacuum levels in divertor chanbers and pump Iinlter throat regiono. Coolant leaks into the vacuus chamber can also be deterted by 
ambient vacuum levels as well as plasna paraneters. Finally, power measurements my be the most critical and useful measurements to be made which detail 1nteraction between the HHF components and the plasma. Plasma power and distribution on HHP couponents, diverted plasn power, relative plasua position, beas aboorption in the plasma, beal pover and distribution, bean posttions, and direct convertor efflclency 'Madings) w11 probably all require measurement at some time.

\section{VIII.3 Control Requirements}

The control aspects of HHF components feature a mixture of open and closed (feedback) loop systems which are responsible to maintain key component parameters within the degign windows (which, In turn, should insure rellability of the components), and provide control 1nput to other device subsystems or components. The present devices primarily operate in open loop control wodes, with diagnostics providing faput to an operator who provides a control function if necessary. The exception to this is mainly in the control of component cooling bystems, where cloged loop control through stand-alone process controllers maintain prescribed performance characteristics. Future devices will demand increasingly automated operation with closed contral loops which finterface directly wth the maln reactor control system. Another aspect of HHF component control involves the early detection or anticipation of componenc fatlures and minimization of the impact or total prevention of these fallures. The anticlpation and prevention of fallures will fall into the category of component performance/rellability control. The early detection and Impact minimization assume component fallure and thus should be addressed In the context of total devfce contral. The following sectlons outline some of the anticipated and present control features of HHF components with respect co componeni performance and overall device operation.

\section{VIII.3.1 Cotponent Performance/Rellability}

Most requirenents for control sysitems which deal with HHF component jerformance address thermomechanical and thermal-hydraulic parameters. Thile the surface condition of the plasma-facing portion of a HHF component is a major consideration in addressing the performance and rellability, active control 18 eleher non-cxistent or will be discussed la the context of control 
of the entire device performance. The IsC of surface conditions of HHF components is also a grey area for wh1ch responstbilities nay be asauned by this task group and/or the PAI Tagk Group. It is recomended that both groups define tequirenents ta thls area while alntaining a strong and continuous interaction.

Table VIII-2 I1sta eone of the potential control loops which involve fHP components as eicher sensors or actuators. The coptrolled paraneters in this table that deal with HHF component perfornance would include optimization of liniter positions (alchough it could be argued that this privarily impacts device performance), component erosion, and component integrity (which Includes fallure anticipation and prevention).

The control of lifiter positions in presently belng utilized on devices with movable limiters such as TFTR. A siople relative position sensor with feedback to a servomotor of some sort is adequate for this task. Both of tilese devices can be located outside of the most severe environzent of the reactor. Optimization of this position can te defined by several paraneters including limiter cemperature, vacuum levels around or behind the limtier, spectes levels in the amblent vacuum, linter potwer, or operator preference. specific algorithas and optiatzation criteria will need to be developed for each fusion device separately.

HHF component erosion portends to be a very gerlous problem in all reactor designs to date. Methods to control the erosfon rates and diatributIon through plasa talloring would be deairable fiom the polnt of view of HHF component rellabllity; however, techniques wh1ch accomplish ihts would appear to be yery difficult if not impossible. If Indeed possibie, they would probably lnvolve atrong trade-offs with plasna perforance, in which case the erosion control nechods wuld probably nat be twplenanted. A much mote real1otic approach 16 to design HNE camponents for misinal erosion, monttor the erosion through the mosi convenient method, and schedule replacement or insitu recoating of the HHF component, or reduce operating levels (possibly shutdown) of the fusion device. The sensing techniques Ilated for thp component erasion monituting in Table VIII-2 are described pore fully in section VIII.5. Each of these could provide a signal to the device operacor wich whuld Indicate that action is necessary to prevent coaponent or device fallure due to excesstve erosion. 
Tab!a VIII.2

Potentfal Control Loops Involving HHF Components

\begin{tabular}{|c|c|c|}
\hline $\begin{array}{l}\text { Controlled } \\
\text { Parameter }\end{array}$ & $\begin{array}{c}\text { Sensing Pareweter } \\
\text { or Device }\end{array}$ & $\begin{array}{c}\text { Activeting Parameter } \\
\text { or Device }\end{array}$ \\
\hline $\begin{array}{l}\text { 0pifimation of } \\
\text { limiter posicion }\end{array}$ & $\begin{array}{l}\text { - Iimiter position } \\
\text { - IImiter temperature } \\
\text { - IImiter power }\end{array}$ & - Iinfter drive \\
\hline Plasma position & $\begin{array}{l}\text { - Iimiter power } \\
\text { - limiter temperature }\end{array}$ & - field coils \\
\hline Beatn strike position & $\begin{array}{l}\text { dump power } \\
\text { dump temperature } \\
\text { duct temperature } \\
\text { - Gcrape-off panel tem- } \\
\text { perature nnd power }\end{array}$ & $\begin{array}{l}\text { - source position } \\
\text { - grid voltages/position } \\
\text { - arc voltage }\end{array}$ \\
\hline Ispurtty levels & $\begin{array}{l}\text { RGA signals } \\
\text { - vacuum levels } \\
\text { - divertor power }\end{array}$ & $\begin{array}{l}\text { - pellet injectors } \\
\text { - gas puffers } \\
\text { - divercor field colls }\end{array}$ \\
\hline $\begin{array}{l}\text { Optimization of pump } \\
\text { IImiter position }\end{array}$ & $\begin{array}{l}\text { - vacuum/RGa signals } \\
\text { behind Ifmicer } \\
\text { - limirer power }\end{array}$ & - limiter drive \\
\hline Total reactor power & $\begin{array}{l}\text { - first vall power } \\
\text { - Iimiter power } \\
\text { - divertor power }\end{array}$ & $\begin{array}{l}\text { - beam power/duty } \\
\text { - RF power/duty } \\
\text { - divertor field colls } \\
\text { - purp limiter position } \\
\text { - Impurity injection }\end{array}$ \\
\hline HHF component eroston & 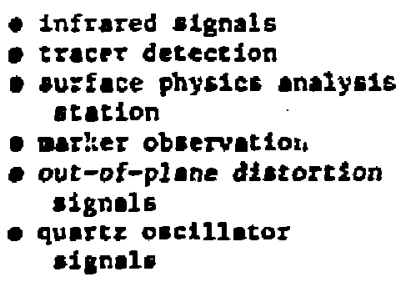 & $\begin{array}{l}\text { component replacement } \\
\text { reactor shutdoun } \\
\text { In-situ coating } \\
\text { schedule }\end{array}$ \\
\hline HHF camponent integrity & 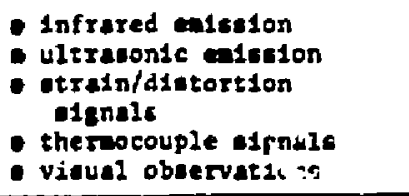 & $\begin{array}{l}\text { - coolant system ad- } \\
\text { juetments } \\
\text { - reactor shutdown } \\
\text { - component replacement }\end{array}$ \\
\hline
\end{tabular}


Table VIII.2 (contd.)

\begin{tabular}{|c|c|c|}
\hline $\begin{array}{l}\text { Controlled } \\
\text { Parameter }\end{array}$ & $\begin{array}{c}\text { Sensing Paraweter } \\
\text { or Device }\end{array}$ & $\begin{array}{c}\text { Activating Parameter } \\
\text { or Device }\end{array}$ \\
\hline $\begin{array}{l}\text { Impact minimization on } \\
\text { plasma due to filf compo- } \\
\text { nent fallure }\end{array}$ & $\begin{array}{l}\text { all of above pius: } \\
\text { RGA signals (tracer } \\
\text { detection) } \\
\text { vacuum levels } \\
\text { coolant pressure } \\
\text { - placma diagnostics } \\
\text { hard x-ray detectors }\end{array}$ & $\begin{array}{l}\text { reactor shutdown } \\
\text { vaculum/electric 1so- } \\
\text { lation of vacuum } \\
\text { vessel }\end{array}$ \\
\hline
\end{tabular}


The control of HHF conponent integrity 18 primarily a case of anticipating faflure and preventing the fallure if posstble, as is erosion control. The fallure mechanisms in. HHF components consist of thermal (critical heat flux, 1088 of cooling, etc.) or mechanlcal (cladding/coating faflure, Internal wall erosion, wall cracking, etc.) fallures. Several techniques can be used to Indicate iminent fallure including excesalve tenperature rate of rise, abnormal temperatures, acoustic emission signals from the component material, and excessive distcrtion. Abnormal occurrences such as these can be sensed and programmed to trip off neutral beans, terminate a plasma pulse, or make adfustuents in cooling system parameters or device power levels. Existing devices already incorporate many of these "Interlock" functlons; however, developnent of much more sophieticated fallure prediction techniques should be pursued for future reactor designs since the benefits of successful techniques in this area are great due to the severe Impact of HHF component fallure on device avallabilicy.

\section{VIII.3.2 Device Operation}

The controlled parameters in Table VIII-2 which inwolve control of device or device subsystems through the use of HHF components include plasms position, beam strike position, plasma impurity levels, reactor power, and rinimization of the Impact of a HHF component fallure on device operatian.

Existing devices and designs of future devices already use limiters for plasma position control. Movable limiters define the plasma edge in TFTR, and limiters provide TFCX feedback control to fleld colls to help locate the plasma in some designs. Mast future reactor designs will probably use some sort of feedback loop which senses limiter power or temperature and feeds back to field-shaping or positioning colls to adjust operating paramecers or control long time-constant plasma drifts. Pregent devices can provide a data base for algorithm development for this control 10op.

Most neutral beam systems presently use some indication of beam-1Ine component loading (1.e., segmented calorimeter beam dumps) to locate the beam or provide divergence information. Automatic control of beam position has been designed for neutral beam teat stands which gradually position the beam through an fterative process on the pulsed beams. Future long-pulse or steady-state beams will require active feedback to source manipulators, Brids, 
and/or arc supplies to provide continuous bean positioning. Once again, present devices most provide the igorithn data base.

Inpurity levels wight be controlled autonarically by feedback signals from vacuum gauges and RGA ${ }^{\dagger}$ s located in the plane edge region, divertor chamber, or pump 11miter throats. Pellet injectors, gas puffers, 1mpurity Injectors, divertor fleld colls, or punp linter positioners ight serve as actuators in this case.

Active power control w11 be necessary for eventual power reactor operat1on. The sensed paraweters will invariably be power to the linfters, first walls, and divertors, and could be meagured by several of the techniques outlined 1n Table vriI-1. The actual control over the plasma power level will probably be accomplished through adjustment of beam and RF powera and duty cycles, divertor efficiency (fleld colla), pump 21miter efficiency (position), and/or 1mpurity injection rates. Again, data base generation on near-term devices ts essential for development of these control systems.

Finally, In the event of HHF component fallure, one would desire to minimize the 1mpact of the fallure on the device operation. Assumfing the component has falled, 1o essential to operation, and no backup mechanism exists, the entire device will have to be shut down (or at least 1dled in some mode which permits repolr of the component). To minimize damage to other systems and cleanup time, the HHF coolant system should be isolated with fast acting valves, and all vacuum and electrical interfaces with the vacuum vessel should be 1solated in a mode compatible with each of the device subsystems. Automatic Interlocks will have to be provided which trigger on signals from fast sensing devices. These sensors could Include vacuum or RGA signals, coolant pressure, or plasma diagnostics. Development of trigger signals which emanate from fusion HHF component Instrumentation might be accomplished in off-line fac1litieg during HHF component developoent, other data for these lnterlock systems might be obtained from operating devices under fault cond1tions or simulated fault conditions.

\section{VIII.4 Operating Environnent and Device Interfacting}

The operating environments in magnetic fusion devices become increasingly severe as the devices progress to the commerclalization stage. Table viII-3 Identifies some of the major concerns for I\&C developers encountered whth the 
environment. associated with mgnet1c fuston devices. The present concerno for I\&C developers are assoclated wh high aegnetic fleld intensities, tive varying agnetic flelds, electromagnetic radiation (alcrowaves, $x$-rayg, and ganass), energetic particle fluxes (lons, electrons, neutral atons), high vacuum and high temperature. Beginnigg with the next generation devices and upgrades (D-T and D-D operation), designers wll have to deal with neutron fluxes, subsequent neutron activated structures, and tritiun contanination. These additional complications compound rapldiy since the I\&C systems nust now deal with additional shlelding, critfum barriers, radiation danage, and remote maintenance. The I $\delta C$ of remote maintenance systems becones a beparately, identiflable area, one which will not be addressed in this technical assessment.

Pulse length will steadily increase with each new generation of devices to the point where iventual steady-stato operation is expected for a demonstration reactor. One of the benefics acconpanying longer pulse lengths will be a recrease in cyclic operation. While cyclic fatigue will continue to be a concern, the associated prohlems w11l probably peak for a device such as ETR where the comblnition of total device lifetine and cyclic operation will be at its worst. Wth increased pulse lengit, greater sclentific understanding, and evclution into an englneering feaglbility made, the requirenents on instrumentation bandwidths may actually decrease, while control systen requirements will greatly increase. The cotal number and diversity of 1notrumentation should hopefully level of $f$ or possible decrease. Again, the most taxing requirements for the I6C systems may very well appear durIng the ETR phase.

Al hough the range of power denstetes on HHF components wll probably not Increase significantly (with the possible exception of compact reactor scenarfos), the total usable power absorbed by these components (especially the first wal1) will increase. This will introduce high-pressure, hightemperature water or other high-efficlency heat transfer wedla, such as liquid metals or high-temperature gases, which will force add1tional I\&C requirements on the HHF component sygtems.

Erow Table VIII-3, it is clear that the IdC systems for HHF components share wany (if not all) of the same environmental concerns of the plasma materials and plasma diagnostics disctplines. Stnce a great deal more effort has already gone Into both of these two areas, a substantial amount of 
Table VIII.3

HHP Component Environnent Related Concerne for I\&C Systems

\begin{tabular}{|c|c|}
\hline Envi ronment & Concern \\
\hline High Heat Flux & $\begin{array}{l}\text { H1gh temperatures, high temperature } \\
\text { gradients, h1gh thermal stresses, thermo- } \\
\text { couple gradient errors }\end{array}$ \\
\hline $\begin{array}{l}\text { High Particle Flux } \\
\text { (1ons, neutrals, electrons) }\end{array}$ & $\begin{array}{l}\text { Sputtering, sharge accumulation, erosion } \\
\text { with subsequent redeposition on Instrument- } \\
\text { ation (especially optical elements), } \\
\text { electrical interference }\end{array}$ \\
\hline Neutron Flux & $\begin{array}{l}\text { Radiation damage, activation of instrument- } \\
\text { atfon, remote maintenance regufrements, } \\
\text { ohfelding, internal heat generation, } \\
\text { decalibration }\end{array}$ \\
\hline $\begin{array}{l}\text { Electromagnetic Radiation } \\
\text { (gammas, x-rays, microwaves) }\end{array}$ & $\begin{array}{l}\text { Radiation damage, oignal interference, } \\
\text { false signal generation, decallbration, } \\
\text { internal heating, ohlelding }\end{array}$ \\
\hline $\begin{array}{l}\text { High Magnetic Field } \\
\text { (including transients) }\end{array}$ & $\begin{array}{l}\text { Decalibration, jxB forces, induced EMF's, } \\
\text { signal Interference, eddy currents }\end{array}$ \\
\hline $\begin{array}{l}\text { Elect romagnetic Induced } \\
\text { Mechanica1 Loads }\end{array}$ & $\begin{array}{l}\text { Positioning errors, vibration, mechanical } \\
\text { fatigce, decalibration }\end{array}$ \\
\hline & $\begin{array}{l}\text { Contamination, } B^{-} \text {heating, } T \text { barrier design } \\
\text { considerations }\end{array}$ \\
\hline High Vacuum & $\begin{array}{l}\text { Sealing considerattons, pressure dffferential } \\
\text { loads, material selection (outgassing) }\end{array}$ \\
\hline High Pressure Hater & $\begin{array}{l}\text { Pressure loads, water contamination, wacer } \\
\text { containment, erosion (high velocity water), } \\
\text { conductivity (electrical) }\end{array}$ \\
\hline Liquid Metals & $\begin{array}{l}\text { Erosion (material compatibility), induced } \\
\text { EMF's, conductivity (electrical), } \\
\text { containment, flow measurement }\end{array}$ \\
\hline Disruptions & $\begin{array}{l}\text { High temperature, erosion, melting, Jedeposi- } \\
\text { tion on instruments, electromagnet1c forces, } \\
\text { electrical transients, thermal shock }\end{array}$ \\
\hline High Voltages & Arcing, material selection, surface condition \\
\hline Cyclic Operation & Fatigue 11fe, transient measurements \\
\hline
\end{tabular}


Information ay be avallable for application to the ISC problens which arise as a consequence of having to perfora in the fusion device ensitonnent. In particular, state-of-the-art data transelssion techniques involving fiber optics, electical isolation and signal discrinination. In chaotic electronagnetic environments which are already in use for the plasma dlagnostics should be adaptable for use in HFF conponent Isc systems. The extensive use of non-contact techniques can aolve many of the problems associated with electromagnetic interference and electrical overload or probes and signal conditioning units due to device (plasma) electrical transients. Although the materials selection for 1nstrunentation is often dictated apriori due to the functional requirements, Information fron the materials comminity could be very valuable when evaluating chotceg between types of a particular Instrument (1.e., type $\mathrm{K}$ thermacouples are probably a much better cholce than W-Re therwocouples in the presence of high neutron fluences) or developing new ones. Valuable information for use of instrumentation in the fusion device environment can also be gleaned from previous experience in the nuclear, space, defense, and high energy physics activitles, where similar; although 1solated, environments have been encountered. Proper use of these sources should minimize many of the requirements for development and in-device testing of HHF component I\&C.

VIII.5 Instrumentation and Control Techniques

A varlety of techniques already exist to measure nost if not all of the parameters which have been defined In Sectlon VIII.2. However, the ability of these techniques to perform in the fusion environment, provide data in the proper form or speed, and interact with control systems ts the key to their applicablity for HHF component uBe.

A cummary of some of the more common neasurement techntques for parameters nentioned in Section VIII.2 is given In Table VIII-2. Sone of these are presently being used with success on operating fuston devices and are denoted by asterisks in Table VIII-1. Most of these w111 have to be upgraded or reconfigured to operate in a neutron environment. Others not yet used on fusion devices w11 require development to operate in the plasma environment and within the physical configuration limitations of the device. Table VIIT-1 ts not intended to represent a complete listing of all possible measurement 
techniques or requirements. The actual techniques used will depend conpletely on the spectflc wessurement required, the u1t1mate application of the messurement sigal, and the constraints of the device on which it is to be used.

Temperature masurenent in existing devices has been done priagrily with theracouples and RTD's. Although thernocouples will probably be used throughout most componen's and time frames, and should be, it nay be difficult to operate RTD's successfully in a severe electromagnetic environment. Testing of thermocouples for callbration drift in 14 MeV neutron fluences should be carried out and probably can be done in conjunction with other neutron 1rradiation tests using the thermocouples as diagnostics. Infrared pyrometers are presently and probably will continue to be one of the most valuable diag:-ostics for hHF components. Although presently in use, upgrading to reduce or eliminate the 1mpact of emissivity changes of the object (primarily due to surface condition changes, although wavelength and tenperature depende ice need to be addressed) and transmission/reflectance changes of optical components (1.e., redeposition coating of windows and radiation damage to windows/mirrors/photosensitive devices) is required. The use of fluoroptics should be explored since this technique is relarively funune to harsh electromagnetlc environments, although linited in tewperature range and probably difficult to locate physically. If gas coolants are used, acoustic and sonic thermometry or other methods common to HTGR technology might be employed.

Measurement of the mechanical properties of HHF components is seldom done in existing devices tn-situ and may ultinately only be employed in off-line test facilities for use in the component development process. However, an increased use of optical techniques for strain/displacement measurement has occurred in the last decade. Some of those techniques auch as optfcal molre methods (1), holography, and laser opecklegrams may be applicable to diagnosis of HHF component mechanical response. Advantages of these techniques include the ability to observe 2-D strain patterns over the whole component and identIfy both In-plane and out-of-plane distortions. Being non-contact techniques, these methods have a good charce of successful operation in the harsh electromagnetic environments. Disadvantages include the significant amount of data analysis required to interpret results and the potentfally extensive development effort required for application to in-situ measurement of HHF 
conponents. Conventions atrain gauges, crack profagation gauges, acceleroseters, and LVDT's ouffer from ingh ousceptibility to electronagnetic effects, low survivability in high-tenperature environments, and the linttation of their ability to measure only local conditions. Recently developed fiber optic strain sensors (2) elminate the electromagnetic naise problems but still have survivability problems and require predeternined location optimization. Most probably, these types of sensors will find application in off-line test facilities but may not be required in operating fusion devices.

The monttoring of surface condztions can be performed by some of the same methods described for the ourface temperatute and strain measurements. Infrared cameras can provide qualitative information on surface changes which induce temperature variations on theraally loaded components (1.e., wall thickness or coating/bond fallure changes in actively cooled components). Hoire and holographic techniques might be used to detect out-of-plane changes in surface due to erosion/redeposttion processes. High-speed photographic techntques, time-lapse photography, and closed-circuit televiston monicors can be used to detect time-dependent surface conditions. Surface welting in a conponent wight be detected though attenuation measurements on a diffracted $x-$ ray beam or changes in the reflected Intensity of 11ght beams. Several techniques to monitor surface erosion inght be explored, one of which would be the use of tracer materials (3) or markers which would be pre-implanted in the HHF component surface and could be detected as they are released or exposed as a regult of surface erosion. The change in frequency of quartz crystal obcillator clrcults due to mass changes have of ten been used in off-line erosion/ redeposition experiments, but thay have limited application as an in-situ technique for fusion devices due to survivability, interpretability, and physical configuration 1ssues. Laser absorption spectroscopy has been used successfully to measure erosion rates with simultaneous species Identification but again may only be useful in off-Iine sinulation experiments since the value of such localized neasurements for interpcetation of overali device performance is questionable. Finally, consideration should be given to util1zing surface analyais spectmens whicil dupilcate the HHF component surface and can be resoved on a scheduled basis from the device environment for off-11ne surface analyols and metallography. Measurements of this type might provide a perfodic monitor of how the actual component surface 18 performing. 
The electric and angnetic paraneters at or near the HHP components can be measured by techniques presently belag used in other parts of the fusion devices. Source parameters can be ldentifled through the use of gaussneters, langmulr probes, and flosing potential neasurements of the electrically Isolated component. Eddy current generation in araor and libiter tiles might be measured with pick-up colls mounted behind the t1les, elthough reaults may be difficult to interpret.

The coolant properties are and will contlaue to be measured by standard techniques used In preseut coolant loops such as thermocouples, flowmeters, and pressure gauges. Most of these can be located outside of the environmentally difficult reglons of the device and do not appear to requite aignifirant redevelopment. For rwo-phase flow property weasurements, a variety of techniques exfst for measurement of vold fractions and bubble dynanics ${ }^{(4)}$. Since these measutements wil probably only be required during off-ine development of HHF companents, these probsbly do not merit redevelopment considerations, Coolant cheqistry manitoring can assist in determination of Internal wall erosion, tritfum levels, and coolant quality; however, these again will probably be usable as they presently exist.

The vacuum and power measurenents are also primarily standard items with litrle reed for development for fusion duvice use other than the previously recomended radiation hardening and signal discrimination/tsolation improvement efforts.

Control logic for HHY components will need to be generated for each device at some point In 1 ts conceptual design after the operational goals and some of the major subsystems have been teasonably well deflned. Af this point, 1t will be lmportant to identify the reactor control systems oo that they can be fully integrated into the total design. While existing devices have little or no control asgoclated with HHF components other than the "interlock" type, this has been primarily related to a lack of need due to the short pulge lengths of these devices, as pointed out previously. However, these devices and their follow-ons are providing a very import.nt data base for control algorithm generation. Basic control theory principles can be applied to the potential control loops identifled in Table vili-2, with algorithins and gross tuning constants draw from this data base. Fine-tuning constants will probably have to be developed on the device itrelf until the 
final coumercialization stage where the control $\log$ fc wil have been bufficleatly developed. Sure1y more control loops, other than those which appear In Table VIII-2, will have elready been Identified, and many of those Identifled will nevar find actual application. Most of the HHF component coolant system control technfques can be taken directly from off-line development faclifties or existing fission resctor coolant control gystems. If certain HHF coolant syatems are not tied Into the main power conversion cycle of the reactor, stand-alone process control by dedicated nicroprocessors may be used and developed entirely in off-line HHF component development facilfties. Obviously, this would still require interfacing to the naln reactor control system In an overall hierarchal control scheme.

In general, active plasma control lnvolving fine adjustments of short time-scale plasma phenomenon (1.e.. plasma Instabliftes) will probably be difficult with HHF componencs a sensors or actuators. The primary thermomechantcal response sensors are limited in speed and prectsion by the time constants and slzes of the HitF componeats. As actustors, HHF components primartly rely on mechanfcal position and thermal properties which again infer lang time constants. Much faster control to probably avallable for fine, real time plasma control with the plasma diagnostics as sensors, and field colls, pawer supplies, and other electrical systems as actuators. Longer term drift compensation of plasma parameters, gross device parameter adjustment, and interlock/alarm functions will probably constitute the major contributions of HHF components to the total reactor control scheme.

\section{VIII.6 Conclustons and Recommendarfons}

From the previous discussions, several conclustons can be drawn with respect to I\&C developsent requirements for HHF components. A few general coments on the development requirements are wade in the next few paragraphs, followed by a sumary of the most critical losues in this area and recomnendatlons on RdD programs which could be pursued to effect solutions to these 1ssues.

A suffictent variety and quantity of I\&c techniques are avallable for system dealling with the HFF component heat alnk thermomechanical and therwa1hydraulic aspects. These techniques are well proven and documented in the open literature. However, as with all I $\&$ C in a magnetic fuston device

$$
\text { VII İ̃-18 }
$$


environment, upgrading nay be necessary to provide radiation hardened data acquisition and control systers and interfaces which can perform reliably in the ievere electromagnetic and radiation fields of future devices. Instrunentation for the plasma-facing side of HFF components and claddings/coatings In duplex structures w11 be very inportant to component rellability diagnosia and could require significant developwent efforta.

In general, the feedback contral of other device conponents or subsystems by HHF components is minimal and is not expected to change significantly in the future. This is primarily due to the relatively slow time constants (thermal and mechanlcal) of the HHF components with respect to other device systems (mainly electrica1) or the existence of more efficlent control techniques. Most of the control interfacing with other systems 1 s and will be in the form of fallure prediction or Identification with the nein control action being device shut down for component replacement or failure impact minimization.

Finally, the developers of the HHF components will naturally ut1lize a far greater number and variecy of Instrumentation techniques than will finally be used in device operation. While developers will require these diagnostics for performance evaluation and design iterations, sufficlent "weeding out" should be performed prior to thetr use in the matn device. Critical measurements (which are specific to the particular component design) should be identIfled by the HHF developers, and the final IdC should be developed with the final application environment in mind tc minimize time-consuming design changes during installation or operation in the fuston device.

Three of the most critical issues which must be addressed in the development of I\&C for HAF components are summarized below. Along with each critical issue are recomrendations for general R\&D efforts which could help provide timely solutions.

- Instrumentation of the "plasma side" of HHF components. This is an area in need of some development, prtmarily due to the severity of the environment in which this portion of the component must operate and be Instrumented, and to the severting of the impact of any undertred performance or fallure on the plasma and, hence, device operation. Non-contact, in-gitu measurement techniques are desirable for instrumenting the plasma side of HHF components due to advantages 
of operation in the presence of severe electronagnetic and radiation flelds, and the response speeds for control loop application. Noncontact measurement techniques in general require more attention to allocation of viewports and space near the device. For this reason, these techniques w11 have to be developed early enough so that they can be included (or at least oufficlent opace and ports can be allocated) in the overall device designs. The associated R\&D needs are: (1) Development of in-situ, real-rime measurement techniques for erosion and redepostition rates and the spatial distribution of these rates. This development effort must address the integration of the measurement system with the operating fusion derice. Development of improved techniques for non-contact surface temperature measurements in the presence of a D-T plasma. Th1s may Involve upgrading of IR systems to reduce or ellminate the 1mpact of emissivity changes of the objeci (primartly due to surface conaltion changes, although wavelength and temperature dependence need to be addressed) and transmission/reflectance changes of optical corponents (1.e., redeposition coating of wiodows and radiation damage to windows/mirrors/photosensitive devices. This development eifort must also address full integration with the intended fusion device.

- Definition of contral loops and algorithms civolving HHF components. Control logic for HHF components needs to be generated for each bevice during its conceptual design. Control loops and algorlthms are not presently well defined for future devices at any development stage. It is important to identify the reactor control systems so that they can be fully integrated into the total design. If engineering data for control algoritha generation is not taken on devices like TFTR, the lack of such data could become a critical problem. The associated R\&D programs should provide the following: (1) The abllity to test HHF component control schemes should be Included in future device designs so that some of these techniques can be Incorporated into the sc.ndard control logic of devices such as ETR and DEMO. Th1s should Include both control of HHF component parameters and contributions of Helf components to the tocal reactor control scheme, which involve long-term drift compensation uf plasma parameters, gross device parameter adjustment, and interlock/alarm 
functions. (2) Developuent of control algorithms for device subsysirem control. These algorithms rely heavily on results from existIng devires. Existing devices and thelr follow-ons should include tests which provide an englneering datu base for control algorithm generation.

- Radiation hardening of ISC sysrems. Upgradirg is neceusary to provide radiation hardened date acquigition and control system and Interfaces which can perfcrm reliably in the severe electromagnetic and radiation flelds of future devices. Suct. Items as optical windows, lenses and mirrorp, fiber optics, and electronics are particularly susceptible to cadiation envirc.dmeuts, and existing devices are not generally desfgned for operat, $\mathrm{c}^{\mathrm{n}}$ in high neutron fluences. To ensure succassili: development of such radiatinn-hardened systems: programs sucil as the Dog-funded, Radiation Hardenting of Fusion Dic-setica Program(5), should be continued, expanded upon, or nthers Initiated, if necessary, so that a prostam exists which will: (1) Define and perform experimerts whlch will provide a data base for radiation effects (fuston-spectfic radiation erivironment) on HHF Instrumentation components. (2) Place more emphasis on device designs which address I\&C radiation hardenting (includes I\&C design, placement, and shlelding). 
1. P. P. Chlang and C. C. KIm, "Some Optical Technlqueg of Ddeplacenent and Stain Mesaurenents on Metal Surfaces," J. Metals, 49, May. 1983.

2. W. C. Szuchy, et al., "EMI Free Fther Optlc Strain Sensor Syatei for TFIR," proc. Tenth Symp, on Fuaton Englneering, Ph1ladelphia, PA, December, 1983.

अ. W. Halverson and P. Stoshans:, "Remote Erosion Hessurements In Controlled Fuston Experinents and Reactors," IbId.

4. G. F. Hewitt, Measurement of Two Phase Flow Parameters, Academic Pres8, New York, NY, 1978.

5. J. Bauer, et al., "Critical Issues in Radiation Hardenting of Fusion Diagnostic Systems," Proc, Tenth syup. on Fusion Engineering, Philadelphia, PA, December, 1983. 